\title{
PARTICIPAÇÃO POPULAR EM SAÚDE: O CASO DOS CONSELHOS GESTORES DE SAÚDE DAS SUBPREFEITURAS DE SÃO PAULO
}

Dissertação apresentada ao Departamento de Ciência Política da Faculdade de Filosofia, Letras e Ciências Humanas da Universidade de São Paulo como requisito parcial para a obtenção do grau de Mestre em Ciência Política.

Orientador: Prof. Dr. José Álvaro Moisés. 
Para o cidadão cívico-republicano que habita meus ideais. 


\section{AGRADECIMENTOS}

Sentado à frente do computador, sem saber por quem iniciar os diversos agradecimentos a fazer, recordo-me das tantas vezes nas quais tive dissertações e teses comigo. Sem perceber a importância desta etapa do trabalho, julgava todos os agradecimentos iguais. Agora, que sei do que se trata, e frente ao pavor de ser injusto e me esquecer de alguém, decidi fazê-los por ordem cronológica de aparecimento das pessoas no processo da dissertação.

Tenho então, primeiramente, que agradecer a meus pais - Horácio e Mirian - que, entusiastas desconhecedores do que se trata de fato meu trabalho, foram, sem sombras de dúvidas, os maiores fãs que tive durante todo o processo.

Vera Schattan me recebeu menino, recém graduado e faminto de "acontecer", em seu projeto, no CEBRAP. Com ela tive a oportunidade para elaborar o primeiro esboço do que veio a ser esta dissertação. Nesta etapa, não posso esquecer a inspiração e ajuda que obtive de Adla Bourdoukan.

Meu orientador, José Álvaro Moisés (a quem não havia conhecido durante a graduação), me recebeu em sua casa, ainda em Janeiro de 2004. Qual não foi minha surpresa ao dele receber mais do que cuidadosa orientação, oportunidades profissionais enriquecedoras, e ter descoberto, sob sua batuta, o gosto de reler um texto. Às funcionárias e funcionários do Departamento de Ciência Política (Rai, Márcia, Ana, Vivian e Leonardo), não teria sobrevivido aos meandros burocráticos sem vocês.

Muito obrigado à Nílian, colega e amiga querida desde os tempos da graduação, pela rigidez e coerência de suas idéias, sempre me trazendo de volta à razão de meus vôos hiperbólicos. Ao querido amigo Diego Coelho obrigado pela desconstrução de diversos momentos de tensão.

Muito grato ao tempo, por ter permitido uma segunda opinião acerca do amigo Rogério Schlegel, a quem também agradeço pelo trabalho tão cuidadoso nas aparas das sobras textuais deste trabalho.

Sou grato pelas colocações e correções feitas pela Professora Marta Arretche na banca de qualificação. Também por este motivo, sou grato à Professora Marta Assumpção Rodrigues, somado a isto o fato de suas costumeiras e solícitas conversas - na recém criada EACH (USP Leste) - acerca de minhas preocupações. À Professora Evelyn Levy, que, nas caronas de volta para casa, apaziguava minhas angústias em relação ao escasso tempo, oferecendo valiosas dicas para seu ordenamento mais eficiente.

Ao amigo Yvo Yoshida, obrigado pelas críticas observações em diversas conversas, fossem elas nos corredores da faculdade ou nas mesas de salas de estudo, restaurantes ou bares. Pelas conversas também sou grato à Carolina Galvanese e Daniel Cara. Muito obrigado ao amigo João Francisco pela cuidadosa leitura de parte deste trabalho. Tiago Borges, a quem muito admiro, salvou-me em difícil momento de meu trabalho. A ele um muito obrigado. Sou grato à CAPES, pelo suporte financeiro à pesquisa.

Finalmente, mas fundamentalmente, sou feliz em poder agradecer - pela paciência em relação à minha ausência, pelas críticas aos diversos rascunhos escritos, pelas conversas nas madrugadas, e pela companhia -, ao Adriano. Importante por existir. 


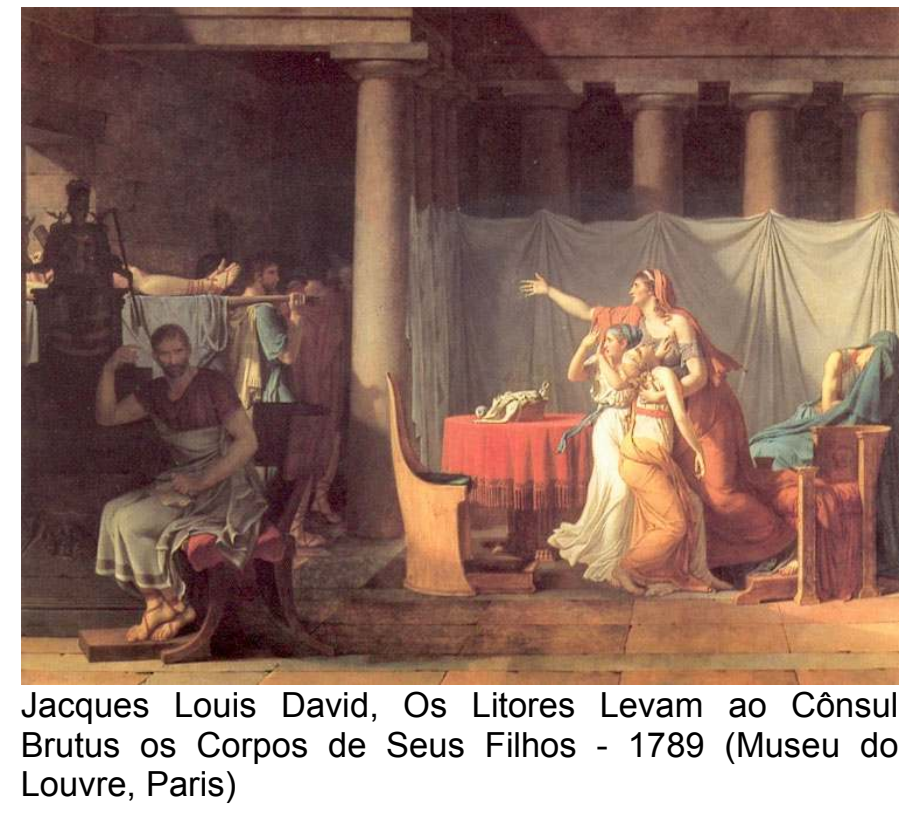




\section{RESUMO}

Este trabalho estuda os Conselhos Gestores de Saúde das Subprefeituras de São Paulo e os conselheiros que deles fazem parte. Estes Conselhos são desdobramentos do Movimento Popular de Saúde, que consiste em fóruns públicos para reivindicação de melhorias no sistema de atendimento à saúde, e tem seu início na década de 1970 em meio a forte repressão política, exercendo importante papel no processo de redemocratização do Brasil. Tal movimento conseguiu exercer intensa influência no capítulo da Constituição Federal que trata do Sistema Único de Saúde, e inscreveu a obrigatoriedade da existência dos Conselhos Gestores nos Municípios da Federação. Estes Conselhos têm por função institucional fazer o controle popular das políticas públicas empreendidas pelo Sistema Único de Saúde. Como se tratam de fóruns participativos, é plausível que sejam pensados e analisados através da teoria da democracia deliberativa. Partindo desta concepção de democracia, discutiu-se a possibilidade de processos deliberativos gerarem capital social e cultura cívica nas pessoas que participam destes fóruns. A parte empírica deste trabalho foi feita por estudos de casos que levaram em conta quatro Conselhos e dezesseis conselheiros. Nesta etapa, avaliou-se a relação entre os desenhos institucionais dos Conselhos Gestores de Saúde e o perfil cívico dos conselheiros que participam destes fóruns.

Palavras-Chave: democracia, deliberação, capital social, cultura cívica, Conselhos de Saúde. 


\begin{abstract}
The present issue discusses the District Health Councils of the Submunicipalities at the city of São Paulo, Brazil and its councilors. These Councils have their basis in the Popular Health Movement, organized in fora of discussion to demand improvements in public policies of health care. That movement, which started in the 1970's under military dictatorship, had an important role in Brazilian political redemocratization. Furthermore, it had a strong influence in 1988 Constitution's chapter about the obligatoriness of the District Health Councils in the municipalities of the Federation. The institutional goal of these Councils is to oversee the effectiveness of the government in implement public policies. The normative dimensions of these fora are upon the deliberative democracy theory. Having this assumption of democracy, I discuss the possibility of these arenas to generate social capital and civic culture among its participants. In a comparative study of four Councils and 16 councilors I analyzed the relation between the institutional framework of these District Councils and the level of civic culture of its councilors.
\end{abstract}

Key Words: democracy, deliberation, social capital, civic culture, Health Councils. 


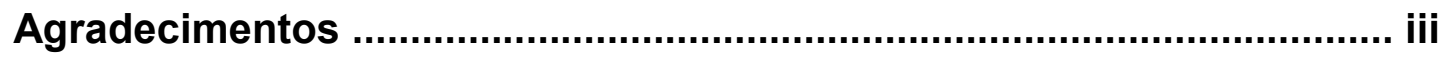

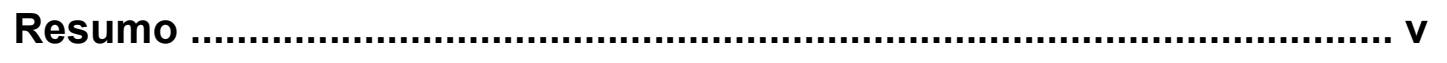

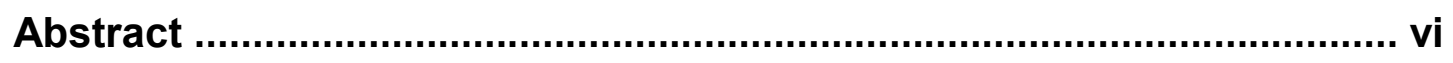

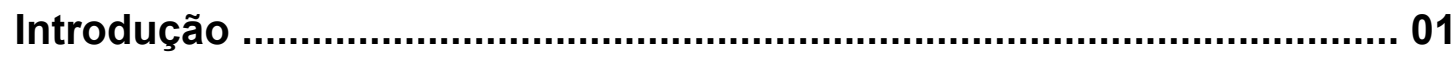

Capítulo I - Democracias e Participação Popular: da teoria à prática ... 05 1.1 - Modificação na Cultura Política e Geração de Capital Social 20

Capítulo II - De Conselhos populares ao Estado: o aparecimento dos Conselhos Gestores de Saúde e os estudos empíricos sobre estes fóruns. 38 2.1 - Os estudos sobre fóruns participativos 50

Capítulo III - Métodos de análise, escolha de casos e apresentação dos dados ............................................................................................. 58

3.1 - Apresentação dos resultados ............................................70

Capítulo IV - Avaliação do capital social, cultura cívica e percepções acerca do SUS 121 4.1 - Considerações finais .................................................. 145

Capítulo V - Comunidade e democracia .................................................... 151

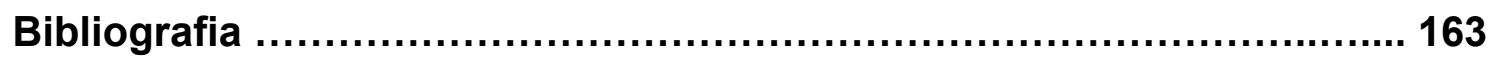

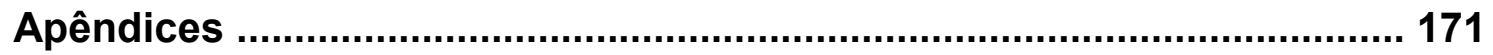

a) Descrição da Metodologia para escolha dos Conselhos e Conselheiros estudados ...................................................... 171

b) Variáveis utilizadas na construção dos indicadores ....... 187

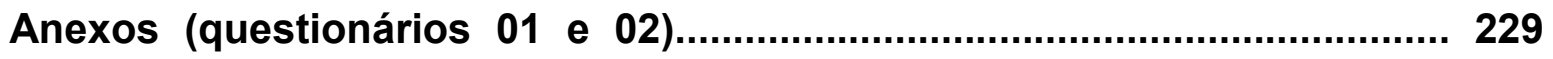




\section{Introdução}

A partir de 1985 o Brasil tem passado por profundas transformações estruturais. Estas, ligadas tanto aos processos de redemocratização e consolidação da democracia no país, quanto à crise e propostas de reforma do Estado brasileiro. Nesse contexto, novas formas de se formular, implementar e analisar a atuação do Estado e a formulação das políticas públicas começaram a emergir.

O estabelecimento da nova Constituição, em 1988, consagrou novos paradigmas de relação entre o Estado e a sociedade, trazendo à tona questões como a participação e a descentralização nas mais diversas esferas das políticas sociais, como no caso da assistência social, educação, habitação, planejamento urbano, transportes, e atenção à saúde.

Especificamente no caso do sistema de saúde brasileiro, após quase duas décadas de reivindicações dos Movimentos Populares de Saúde no sentido de obterem a universalização do atendimento à saúde, implementou-se o Sistema Único de Saúde (SUS). Este projeto de gestão da saúde trouxe em seu bojo a idéia de que a descentralização administrativa, a participação popular e a fiscalização social podem ser práticas importantes na tentativa de se buscar uma maior qualidade e equidade na distribuição dos serviços públicos de saúde.

O SUS estabeleceu a participação popular como forma de fiscalização das ações do Estado. Isto refletiu numa mudança na concepção dos papéis do Estado e da sociedade na formulação e gestão das políticas governamentais em saúde. A criação dos Conselhos de Saúde (nacional, estaduais, municipais e posteriormente distritais, no caso de São Paulo), que têm caráter paritário, ${ }^{1}$ carrega a idéia de que não cabem única e exclusivamente ao Estado a decisão final acerca da alocação de recursos e a gestão dos serviços e equipamentos

\footnotetext{
${ }^{1}$ Nesta concepção, a população usuária do SUS detém $50 \%$ das cadeiras de representação interna, e os responsáveis por operar o sistema (poder público, os funcionários do sistema público de saúde, e os prestadores de serviços públicos e privados) repartem os demais $50 \%$.
} 
públicos de saúde. Incluindo-se a sociedade civil nas discussões acerca das políticas públicas de saúde, estabeleceu-se uma busca de soluções conjuntas, tendo em vista as particularidades de cada localidade específica.

Estes mecanismos propiciaram a entrada de novos atores no processo de formulação e gestão das políticas de saúde. Atores que até então buscavam a realização de seus interesses através de outras formas de atuação frente ao poder público. ${ }^{2}$ Antes, a gestão cabia unicamente ao Estado. Depois dos Conselhos, a população, através de seus representantes, ganhou o papel de fiscalização das ações estatais, assim como de levantamento de problemas e proposição de soluções.

Pode-se supor, porém, que por se tratarem de espaços de deliberação, para além da fiscalização das atividades públicas que os Conselhos devem exercer legalmente, a participação nestes espaços desempenha um outro efeito sobre as pessoas que deles participam. Isto ocorre pois a idéia de deliberação encerra a tentativa de se estabelecer um consenso discursivo entre as pessoas e grupos que participam do debate. Assim, a ordem social é construída a partir da partilha de significados, o que possibilita a mudança de posições e opiniões dos atores envolvidos acerca dos temas tratados. É plausível pensar que estes processos possam contribuir para indivíduos mais tolerantes, mais confiantes nas instituições e processos democráticos e nas pessoas de maneira geral. Estas implicações podem ser teoricamente analisadas à luz das teorias do capital social e da cultura cívica.

Todavia, a maioria dos estudos acerca destes espaços deliberativos teve por questões sua eficiência no tocante à inclusão de segmentos sociais outrora excluídos da arena de decisões políticas; sobre qual seja a função destes espaços deliberativos; como os potenciais participantes devem chegar a estes espaços; que assuntos devem apreciar; a freqüência de seus encontros; o empenho dos

\footnotetext{
${ }^{2}$ A população se organizava nas Comunidades Eclesiais de Base, nas Pastorais da Igreja Católica, nos clubes de mães e associações de bairro, Partidos Políticos como o MDB e o PCB, e Sindicatos. De meados da década de 1970 em diante, apareceram os Conselhos Populares de Saúde.
} 
gestores e políticos para com o projeto; sua eficiência frente à (re) alocação de equipamentos de saúde; entre outros aspectos operacionais (Fung, 2004).

Há muito poucas análises que consideraram as relações culturais intrínsecas a estes espaços participativos. Há aqueles que sustentaram que cultura cívica e capital social não podem ser gerados, e são condições a priori para a boa governança e consolidação democráticas. (Almond e Verba, 1963; Putnam1999, 2001).

Contudo, existem estudos como o de Cristina Rojas, que analisou o processo de descentralização desenvolvido pelo governo central da Colômbia a partir dos idos de 1990, e que afirma que confiança, cooperação e reciprocidade se desenvolveram a partir de ações governamentais bem conduzidas. A autora demonstrou que o fato do governo utilizar-se de campanhas publicitárias e ampliação de áreas de convivência social, levou os indicadores de criminalidade, acidentes de trânsito e arrecadação de impostos a melhorarem significativamente em Bogotá (Rojas, 2002).

Advogando a hipótese de que o comportamento político das pessoas pôde ser modificado através da participação, Rebeca Abers defendeu que foi exatamente isto o que ocorreu com a população de Porto Alegre, no Rio Grande do Sul, com a decana experiência do Orçamento Participativo. Os participantes deste processo, segundo a autora, aprenderam como debater e votar questões complexas e a permitir a expressão de todos os participantes do fórum (Abers, 2001).

Partindo do suposto que haja intercâmbios entre cultura política e instituições democráticas, pode-se perguntar: há alguma relação entre as diferentes formas de organização e funcionamento dos Conselhos Gestores de Saúde e as atitudes e orientações de seus conselheiros em relação ao sistema político?

Para pesquisar este problema, empreendi uma investigação experimental com 16 conselheiros, distribuídos em quatro Conselhos, com vistas a detectar se há 
relações entre o desenho institucional dos Conselhos Gestores de Saúde e as percepções e práticas políticas de seus conselheiros.

Para estes 16 conselheiros foi aplicado um questionário para averiguar seus julgamentos e atitudes acerca de mecanismos do sistema político. Com dados acerca da organização dos CGS, outra etapa desta pesquisa compreendeu a verificação de em que medida o desenho institucional do Conselho tem relações com os valores e atitudes políticas dos conselheiros.

Para tanto, os conselheiros foram questionados acerca de suas percepções sobre o funcionamento das instituições da saúde, sobre sua tolerância, confiança interpessoal e nas instituições de saúde e democráticas e sua capilaridade social em suas relações com a comunidade vizinha.

Neste trabalho, o primeiro capítulo apresenta uma breve discussão sobre os modelos de democracia elitista, pluralista, participativo e deliberativo e uma discussão mais acurada sobre cultura cívica e capital social, apresentando criticamente o debate acerca da questão de que uma boa comunidade cívica fundamenta bons governos (Putnam, 1999, 2001; Almond e Verba, 1963), versus a hipótese que advoga a possibilidade de que ações institucionais de governos possam gerar uma comunidade cívica (Ostrom, 1999; Rojas, 2001; Locke, 2000). Já o segundo capítulo relata, brevemente, a formação e lutas do Movimento de Saúde, que originou a idéia dos Conselhos Gestores de Saúde, bem como a discussão de estudos empíricos sobre o funcionamento destes espaços. No capítulo três, define-se a hipótese do trabalho e suas variáveis, e detalha-se a metodologia para a seleção dos casos estudados. Também neste capítulo apresentam-se os dados com os resultados da pesquisa. No quarto capítulo apresenta-se a análise dos dados. No quinto, e último, capítulo, oferece-se a conclusão do trabalho, associada a uma concisa defesa normativa de um conceito de democracia e de cidadão. 


\section{Capítulo I - Democracias e participação popular: da teoria à prática.}

Atualmente, poucas idéias parecem ser tão amplamente aceitas como aquelas que envolvem a democracia. Contudo, o sentido do termo é fluido e diversificado. Cabe aqui, portanto, uma breve apresentação dos fundamentos e conceitos que associo à democracia, de forma a melhor conceitualizar a relação entre participação e deliberação popular e desenvolvimento de cultura cívica - objeto deste trabalho.

Pode-se enquadrar a democracia em duas grandes arenas de debate: a liberal e a republicana. Para os teóricos do primeiro grupo, o processo democrático cumpre a função de programar o Estado no interesse da sociedade - sendo o Estado o aparato de administração pública, e a sociedade o sistema de relações entre pessoas privadas e seu trabalho social, estruturados em termos de uma economia de mercado. Neste sentido, a formação política das vontades dos cidadãos tem por função agregar e impor interesses sociais privados frente a um aparato estatal especializado no emprego administrativo do poder político, visando a garantir fins coletivos.

Já para a concepção republicana, a democracia não se esgota em um processo de mediação, sendo elemento constitutivo de todo o processo de formação da sociedade. Deste prisma, a infra-estrutura dos espaços públicos, políticos e da sociedade civil assume o papel estratégico de garantir a força integradora e a autonomia da prática de entendimento entre os cidadãos (Habermas, 1995, p 3940).

Neste debate, é possível distinguir-se esquematicamente quatro perspectivas diversas, no que se refere aos sentidos atribuídos à democracia: elitistas e pluralistas, no campo liberal; e participcionistas e deliberacionistas, no campo republicano. 
Ao se buscar o sentido de como a democracia opera contemporaneamente, vê-se que muitos processos históricos - como o colapso do chamado "socialismo real", o declínio do Welfare State, bem como o corrente processo de liberalização de mercados e fluxos internacionais de capitais -, contribuíram para a complexificação de uma possível resposta. No atual estágio de desenvolvimento dos sistemas políticos, autores interpretam-na como princípio universal de legitimação (Held, 1987); como o método de escolha das elites governantes (Schumpeter, 1987); como processo de disputa e acesso de grupos diversos ao poder (Dahl, 2005); como meio de realização das vontades dos cidadãos e dissipação das distorções sociais (Pateman, 1992 e McPherson, 1977); e ainda como meio de deliberação ativa acerca do ato de governar e ser governado (Habermas, 1995).

Nesta discussão, pode-se identificar debates acerca das macroestruturas que definem o quadro institucional dos regimes democráticos - como eleições periódicas e livres, separação de poderes, regime de governo, e respeito a direitos e garantias individuais. Pode-se, também, notar o debate de uma perspectiva que diz respeito à criação de novos espaços de participação e deliberação, o que questiona as macroestruturas do regime democrático no sentido de desafiar sua estrutura representativa atual, apoiada no sufrágio universal.

O conceito de participação está fundamentado em noções de igualdade econômica e democracia social, no sentido de dotar a convivência humana de maior eqüidade no acesso a bens materiais e culturais. Neste sentido, a provocação imposta à democracia representativa consiste em desempenhar bem a representação e assegurar igualdade econômica e cultural, além de gerar formas eficientes de participação e deliberação popular no, e acerca do, Estado (Goulart, 2002).

Por estas razões, apresento a seguir os quatro modelos de democracia que se mostram os mais influentes neste debate. 


\section{Os elitistas}

A democracia atual tem cerca de dois séculos. No cerne das reflexões acerca da democracia está Max Weber, pensador que formulou de maneira clara, e indo contra a corrente da burocracia alemã de seu tempo, a idéia de que o sufrágio universal não representa um perigo e promove, antes, uma estabilização e institucionalização da luta política. Neste sentido, Weber supunha que o partido político organizado de acordo com o formato do Estado, com seu líder político carismático, formasse um baluarte confiável para conter aquilo que ele descrevia como o ódio desorientado das massas, ou golpismo sindicalista (Nobre, 2004, $p$ 24).

A prática política em países ocidentais consagrou um modelo que, tendo o sufrágio universal e a política partidária competitiva como pilares fundamentais do sistema, passou a ser percebido como uma democracia partidária competitiva.

Contudo, está subjacente a esta análise uma dissociação entre a vontade popular e o resultado dos processos democráticos. "Logo que a vontade do povo se expressa através do instrumento de um partido competitivo que luta pelo cargo governamental, o que foi expresso cessa de ser a vontade do povo e se transforma, ao contrário, em um instrumento da forma em si mesma e na dinâmica posta em movimento pelos imperativos da competição política". (ibid, ibidem).

Outro autor, Robert Michels, com sua "Lei de Ferro das Oligarquias", apresentou três efeitos da competição política sobre a dinâmica partidária. O primeiro é o fato de que se pode observar uma desradicalização da ideologia do partido, por tentar obter o maior número de votos do conjunto do eleitorado e pela necessidade de construir acordos e coalizões eleitorais e de governo. Em segundo lugar, os partidos se burocratizam e centralizam suas estruturas administrativas, lançando mão de campanhas permanentes, o que desmobiliza, gradualmente, suas bases em favor de quadros militantes profissionais. Finalmente, as condições de competição política acarretam uma corrosão da identidade coletiva, em favor de 
uma administração pragmática da heterogeneidade cultural e de valores dos filiados. ${ }^{3}$

Destas reflexões de inspiração weberiana sobre a democracia, derivou um modelo conhecido como modelo elitista de democracia, o qual se esforça por ser realista, embora mantenha premissas normativas. $O$ autor paradigmático desta vertente de democracia é o economista Joseph Schumpeter, em seu clássico livro de 1942, Capitalismo, Socialismo e Democracia. Para este autor, democracia é a luta entre líderes políticos rivais, que pertencem a partidos específicos e disputam o direito de exercer o governo. Neste modelo, a democracia é um arranjo institucional capaz de produzir decisões necessárias à reprodução social e econômica das sociedades nas quais não haja um mesmo conjunto de valores últimos partilhados por todos os membros do corpo político. Estes arranjos, garantidos pela democracia, não têm quaisquer compromissos morais intrínsecos em suas lógicas de operação, podendo argumentar-se que a democracia pode servir para diversos fins. Neste sistema, participam apenas membros das elites políticas que estejam em partidos e cargos públicos, sendo relegado ao cidadão comum o irrelevante papel de selecionar os líderes quando convocados para tanto.

Para esta escola, não há nenhuma possibilidade de que os eleitores estabeleçam a agenda política ou tomem as decisões políticas, cabendo aos partidos políticos a agregação dos interesses coletivos e a decisão de quais destes são relevantes ao processo político. A verdadeira função do voto é a de resolver a competição entre as diferentes elites políticas que aspiram ao poder.

Este modelo é limitado pelo fato de que despojou a democracia de valores como a autodeterminação, participação, igualdade política, processos discursivos da formação da vontade política entre iguais, e a influência da opinião pública autônoma em relação às decisões, limitando a política a um método, sacrificando os princípios da legitimidade democrática, que são o núcleo e fundamento do conceito.

\footnotetext{
${ }^{3}$ MICHELS, R. Partidos Políticos. Senzala, 1987.
} 


\section{Os pluralistas}

Já os pluralistas partem de uma crítica aos elitistas por julgá-los pouco realistas. Sua crítica vai no sentido de afirmar que o modelo schumpeteriano está inevitavelmente calcado no cidadão individual em contraposição com a liderança eleita, tornando aquele cidadão frágil frente às dinâmicas de grupos e associações políticas. Deste prisma, quase nenhuma atenção foi dada pelos elitistas a grupos intermediários (associações comunitárias, grupos religiosos, sindicatos, etc.) os quais perpassam as vidas das pessoas e as conectam de formas complexas a vários tipos de instituições. Os pluralistas tentam remediar esta lacuna na análise elitista examinando diretamente a dinâmica da política de grupos, explorando as interconexões entre competição eleitoral e atividades de grupos com interesses organizados.

Os pluralistas colocaram ênfase no processo resultante da combinação de esforços individuais que se aglutinam em grupos e instituições visando à competição pelo voto. Eles afirmaram que a existência de diferentes interesses competitivos funciona como fundamento do equilíbrio democrático e do desenvolvimento favorável de políticas públicas (Held, 1987, p 170).

Contemporaneamente, como ícone do modelo pluralista está Robert Dahl, em seus Poliarquia, de 1971, e de Um Prefácio à Teoria Democrática, de 1956. ${ }^{4}$ Toda a questão para este autor está na tentativa de compreender a lógica de distribuição de poder nas democracias ocidentais. Desta maneira, o cerne da sua análise está em sua concepção de poder, concepção esta definida como a capacidade de grupos imporem objetivos em face da oposição de outrem.

\footnotetext{
${ }^{4}$ Estudiosos separam dois momentos da carreira de Robert Dahl. O primeiro marcado por estes dois livros citados e o segundo a partir da publicação de $A$ preface to economic democracy, em 1985. A diferença fundamental entre estes dois momentos deste autor é a de que, no livro de 1985, ele assume que o capitalismo corporativo tende a produzir desigualdades tão grandes nos recursos sociais e econômicos que elas geram severas violações na igualdade política, portanto, do processo democrático. Sua posição anterior era a de que dado o leque de grupos de interesses, estes grupos buscavam igualmente por influência política. Para detalhes deste debate, além dos originais, ver HELD, D. Modelos de democracia.
} 
O poder é estruturado de maneira não-hierárquica e competitiva, sendo indissociável de um eterno processo de barganhas entre grupos que representam diversos interesses, incluindo organizações comerciais, sindicatos, partidos políticos, grupos étnicos, estudantes, grupos religiosos, etc. Estes interesses estão estruturados em torno de clivagens econômicas ou culturais, como classes sociais ou grupos raciais, por exemplo. Nesta visão, a democracia é definida como estímulo e garantia da competição entre grupos de interesses, salvaguardadas proteções às minorias e aos direitos de participação, aumentando a inclusão no sistema democrático.

Assim, os resultados políticos advêm da tentativa do governo de fazer a mediação entre as diferentes demandas. Neste processo, o sistema político se torna quase indistinguível do fluxo das barganhas e das pressões competitivas de interesses. "Na verdade, os departamentos individuais do governo podem ser, algumas vezes, melhor concebidos como sendo outro tipo de grupo de interesse, uma vez que eles próprios concorrem por recursos escassos" (Held, 1987, p172).

Ao terem analisado as políticas de grupos de interesses, os pluralistas corrigiram a ênfase unilateral dada pelos elitistas à política das elites e ao excesso de importância dado à capacidade dos políticos de moldarem a vida contemporânea. Pata tanto, os pluralistas enfatizaram as muitas formas de padrões de interação, competição e conflito inscritos na administração, organização e políticas do Estado moderno.

Ao conceberem a democracia desta forma, todavia, os pluralistas acabaram por remodelar seu significado, reduzindo a história da democracia a um padrão existente. Foram referidas meramente à prática atual das democracias questões como a extensão apropriada da participação popular e as esferas mais adequadas para a regulação democrática. "Os ideais e métodos da democracia se tornaram, por padrão, os ideais e métodos dos sistemas democráticos existentes. Uma vez que o critério crítico para adjudicar entre teorias de democracia é seu grau de 'realismo', os modelos que se afastavam da prática democrática atual, ou que estivessem em atrito com a mesma, poderiam ser dispensados como 
empiricamente imprecisos, 'irreais' e indesejáveis" (grifos do autor - Held, 1987, p178).

\section{Os participacionistas}

A escola participacionista, comumente alcunhada de "nova esquerda", toma como ponto de partida de suas reflexões as colocações originais de Karl Marx. ${ }^{5}$ Deste prisma, o mercado capitalista é visto como cristalizador de desigualdades anteriormente produzidas, principalmente a dicotomia gerada entre a existência de detentores dos meios de produção e seu revés, os quais são obrigados a vender sua força de trabalho para os primeiros, em busca de sua manutenção vital.

Desta forma, a nova esquerda contesta as idéias da democracia liberal contemporânea de que os indivíduos são livres e iguais. Deste prisma, as desigualdades de classe, sexo ou raça, reduzem enormemente os parâmetros nos quais se pode afirmar que as pessoas são iguais. Para que os cidadãos venham a ser livres teriam que se envolver direta e continuamente na regulação da sociedade e do Estado.

Para esta escola, o Estado não é separado ou imparcial em relação à sociedade, e está preso à manutenção e desigualdades da vida diária. Assim, se o público e o privado estão entrelaçados de forma complexa, as eleições tornam-se um mecanismo insuficiente para assegurar a responsabilidade das forças realmente envolvidas no processo de governo.

Destarte, torna-se fundamental superar as desigualdades materiais que impedem a efetividade das liberdades, as quais são apenas formalmente prescritas sob a égide do Estado de Direito do capitalismo. Desta forma, faz-se necessário que se corrijam os déficits de formação política da opinião e da vontade que daí resultam,

\footnotetext{
${ }^{5}$ A escola participativa tem por referências: Carole Pateman (Participação e Teoria Democrática, 1970), e C. B. Mcpherson (The Life and Times of Liberal Democracy, 1977).
} 
o que implica, antes de qualquer outra coisa, ampliar a participação nos processos decisórios.

Para tanto, o sistema político ideal deveria combinar partidos competitivos e organizações de democracia direta. O sistema partidário, deste prisma, deveria ser reorganizado com base em princípios menos hierárquicos, de maneira que os líderes partidários se tornassem mais responsivos frente às pessoas que representam. Estes partidos deveriam operar dentro de uma estrutura parlamentar limitada por organizações plenamente auto-administradas no local de trabalho e nas comunidades locais dos cidadãos.

Para que esta participação possa ser conquistada, os direitos democráticos precisam ser estendidos do Estado ao empreendimento econômico e a outras instituições centrais da sociedade.

Esta escola reconhece as limitações da participação direta em assuntos nacionais, devido a dois motivos: a) ao volumoso demos para reuniões coletivas, b) à influência infinitesimal que caberia a cada indivíduo no resultado de escrutínios. Assim, a participação direta dar-se-ia localmente e sobre questões imediatas, sendo o papel das grandes decisões relegado às instituições centrais da democracia liberal (partidos e representantes políticos e eleições periódicas).

Ao tentar combinar e remodelar noções das tradições liberal e marxista, os participacionistas dizem muito pouco sobre diversos fatores: como a economia deveria ser organizada e relacionada ao aparato político, como as instituições da democracia representativa deveriam ser combinadas com as de democracia direta, como seriam impostos limites ao poder das organizações administrativas, e como aqueles que não desejassem participar do sistema político poderiam fazê-lo. Ademais, não explicitam como seu modelo poderia vir a ser concretizado e toda a questão dos estágios de transição (Held, 1987,p 237).

Assim, e a despeito de estarem corretos ao tratarem das implicações dos princípios democráticos na estrutura organizacional da sociedade e do Estado, os 
participacionistas ficam vulneráveis à crítica de que tentaram resolver prematuramente as relações altamente complexas entre liberdade individual, questões distributivas (questões de justiça social) e processos democráticos, tendendo a deixar que as relações entre estas esferas fossem especificadas por uma '"razão democrática', uma sábia e boa vontade democrática, para determinar resultados políticos justos e positivos" (Held, 1987, p 238).

\section{Os deliberacionistas}

O modelo da escola deliberativa apresenta uma teoria da democracia com cerne no respeito essencial a procedimentos imparciais de deliberação. Estes procedimentos, que visam à efetivação de um consenso, devem respeitar: i) que a participação na deliberação tenha sido regulada por normas de igualdade e simetria; ii) todos tenham tido o direito de questionar os tópicos fixados para debate; iii) todos tenham podido apresentar pontos e introduzir argumentos reflexivos sobre as regras do procedimento discursivo e o modo através do qual tenham sido aplicadas e conduzidas.

Autores como Jurgën Habermas salientam em suas obras a importância da deliberação pública para o funcionamento democrático. São teorias que se colocaram em oposição ao modelo de democracia que dominou os debates na primeira metade do século XX - embalados por autores como Weber e Schumpeter - que vêem com ceticismo os debates envolvendo tradições culturais distintas.

Desde o início de suas reflexões, Habermas demonstrou preocupação com a formação de uma esfera para argumentação. Este pensador marcou o conceito de esfera pública com características que são centrais ao debate democrático contemporâneo: a idéia de um espaço para interação face-a-face diferenciado do Estado, onde os indivíduos possam interagir uns com os outros, debatendo as decisões tomadas pelas autoridades políticas. Nestes espaços também se debate 
o conteúdo moral das diferentes relações existentes no âmbito social e são apresentadas demandas ao Estado.

No interior de uma esfera pública democrática, as pessoas discutem e deliberam acerca de questões políticas, adotando estratégias para tornar as autoridades políticas sensíveis às suas deliberações. Desta maneira, a argumentação estabelece uma dinâmica no interior da política que não é particularista ou movida pelo desejo de dominar outros indivíduos ou grupos. Nesta dinâmica está presente a idéia de que o uso público da razão estabelece uma relação entre participação e argumentação públicas, processos que se realizam na forma institucionalizada das deliberações nas instituições parlamentares ou na rede de comunicação dos espaços públicos políticos.

\section{Ação Comunicativa}

Habermas propôs a idéia de um consenso discursivo, elaborando uma teoria da reflexividade da ação social. Com sua obra Teoria da Ação Comunicativa, estabeleceu duas dimensões centrais para este empreendimento: a primeira delas foi a construção de um conceito de mundo social reflexivamente adquirido. A segunda foi a noção de uma forma de ação intersubjetiva e voltada para um consenso comunicativo (Habermas, 1987).

Neste mundo social reflexivo há a idéia de que a ordem social seja construída a partir da partilha de significados. Tal partilha se dá nos processos de comunicação, nos quais os participantes atribuem os vários elementos de uma situação de ação a cada um dos três mundos: o objetivo, do domínio das coisas; o social, que é o reino das normas e instituições; e o subjetivo, que é o plano das vivências e sentimentos.

A cada um desses mundos correspondem diferentes pretensões de validade. Ao mundo objetivo correspondem pretensões de validade referentes à verdade das afirmações feitas pelos participantes no processo comunicativo. Ao mundo social 
correspondem pretensões de validade referentes à correção e à adequação das normas; e ao mundo subjetivo correspondem pretensões de veracidade, o que significa que os participantes do diálogo sejam sinceros na expressão dos seus sentimentos.

Assim, em primeiro lugar, as pessoas, ao interagirem, coordenam suas ações. Do conhecimento que elas partilham do mundo objetivo depende o sucesso ou o insucesso de suas ações conjuntas. Em segundo lugar, as pessoas interagem orientando-se segundo normas sociais que já existem previamente ou que são produzidas durante a interação. Essas normas definem expectativas recíprocas de comportamento, sobre as quais todos os participantes têm conhecimento. Este tipo de ação não é avaliada pelo seu êxito, mas pelo reconhecimento intersubjetivo e pelo consenso valorativo, sendo que sua violação gera sanções. Em terceiro lugar, em todas as interações as pessoas revelam algo de suas vivências, intenções, necessidades, temores etc., de tal modo que deixam transparecer sua interioridade.

No que diz respeito tanto à coordenação de ações como às avaliações éticas e às manifestações subjetivas, a linguagem ocupa um papel fundamental. A legitimação dos valores, correção normativa e veracidade que toda a ação comunicativa pressupõe não são alcançadas por uma racionalidade meio-fim, mas somente pela argumentação em função de princípios reconhecidos e validados pelo grupo.

Habermas propôs um modelo ideal de ação comunicativa, em que as pessoas interagem e, através da utilização da linguagem, organizam-se socialmente, buscando o consenso de forma livre de toda a coerção externa e interna.

Desta forma, Habermas apresentou a situação comunicativa ideal: o discurso. Para ele, discurso (Diskurs) refere-se a uma das formas da comunicação ou da "fala". Tal forma de comunicação tem por objetivo fundamentar as pretensões de validade das opiniões e normas em que se baseia implicitamente a "interação", também chamada de "agir comunicativo". 
O discurso teórico ou prático, conforme se refira a pretensões de validade de opiniões ou de normas sociais, possui dois aspectos: um aspecto intersubjetivo para classificá-lo como uma espécie do gênero comunicativo, e um lógicoargumentativo, que serve para determiná-lo como caso específico da fundamentação de pretensões de validade problematizadas (Gonçalves, 1999).

O processo de comunicação que visa ao entendimento mútuo está na base de toda a interação, pois somente uma argumentação em forma de discurso permite o acordo de indivíduos quanto à validade das proposições ou à legitimidade das normas. Por outro lado, o discurso pressupõe a interação, isto é, a participação de atores que se comunicam livremente e em situação de simetria.

Assim, a definição de uma divergência coloca um problema de tipo peculiar, pois em um processo cooperativo de interpretação ninguém possui o monopólio da interpretação correta (Habermas, 1987). Desta forma, o autor da teoria da ação comunicativa supôs que as formas de argumentação são próprias ao mundo social, continuando, portanto, a ter presença nas sociedades contemporâneas, mas sendo passíveis de diversas interpretações em diferentes situações.

Desta maneira, não se pode supor que aquele que vier a divergir da vontade da maioria esteja errado. Assim, é possível que se aplique esta forma de sociabilidade à política contemporânea através da percepção de que o problema da legitimidade na política não está ligado apenas ao problema da vontade da maioria no processo de formação da vontade geral, mas, também, a um processo de deliberação que possa contar com a participação racional de todos os indivíduos interessados ou afetados por decisões políticas.

Nota-se que este tipo de processo - que envolve uma discussão racional entre indivíduos iguais - reinterpreta a relação entre maioria e minoria, uma vez que não é a proporção de votos que estabelece esta diferença, mas, antes, a chegada a uma posição racional no debate político que satisfaça a minoria. Há também, a partir desta visão conceitual, a possibilidade de mudanças no conceito de valores, uma vez que a política deliberativa deve ser uma rede de processos de barganha 
regulados de forma justa por vários processos de argumentação, sejam eles pragmáticos, éticos ou morais.

\section{Deliberação e cultura política}

Ao se cotejar os pressupostos da teoria democrática deliberativa com os da teoria da cultura política, que igualmente abraço como referencial conceitual, pode-se ler as implicações da primeira a partir da perspectiva da teoria da cultura política: a qual não desconhece, sequer desvaloriza, o papel das instituições deliberativas no processo de formulação dos valores e crenças dos cidadãos a respeito do mundo da política.

Neste trabalho, parto do suposto de que as proposições da escola deliberativa e suas preocupações - como a formação de esferas próprias para a argumentação coletiva, os processos deliberativos que estabelecem dinâmicas sociais que não são particularistas ou movidas pelo desejo de dominar outros indivíduos ou grupos - são as mais acertadas ao propósito desta pesquisa. Isto porque esta linha teórica conta com os instrumentos conceituais mais adequados para lidar com a complexidade dos processos culturais envolvidos na participação e deliberação popular - além de oferecer os ganhos já apontados na definição substantiva dos paradigmas da democracia.

Em situações que envolvem disputa e necessitam de votos, as pessoas e grupos envolvidos nestes processos - cônscias de que a divergência é dado das relações sociais, e de que nenhum ator detém o monopólio da interpretação correta - não se sentem estimuladas a buscar uma proporção de votos que estabelecerá a maioria, mas, sim, um processo de negociação que facilite o estabelecimento de um ponto no qual a minoria também seja satisfeita.

Também é plausível supor que devido ao fato de as pessoas envolvidas em processos deliberativos - ao terem compartilhado conhecimentos, valores e 
sentimentos acerca do mundo da vida ${ }^{6}$-, avaliem suas performances individuais em função da consecução de seus projetos e objetivos. Assim, podem partilhar regras e valores sociais, gerando normas de reciprocidade e redes horizontais de relacionamentos.

Além do mais, participar destes processos abre a possibilidade de mudanças nos conceitos de preferências das pessoas, uma vez que diversas demandas foram apresentadas e confrontadas nestes fóruns, dando a possibilidade de que os indivíduos ponderem e reavaliem suas posições, já que no conceito de mundo social reflexivo há uma forte idéia de que a ordem social seja construída a partir da partilha de significados.

Tais procedimentos - dadas as pretensões de validade dos cidadãos referentes à verdade das afirmações feitas pelos participantes no processo comunicativo, à correção e à adequação das normas sociais compartilhadas -, permitem que os participantes do diálogo, ao interagir, possam gerar ou reinterpretar suas ações coletivas, baseados em reavaliações ou novas compreensões acerca das normas sociais que os amalgamam e do compartilhamento e definição de suas expectativas recíprocas de comportamento.

Estes tipos de coordenações, como sustentei, são avaliados pelo seu reconhecimento intersubjetivo e pelo consenso valorativo que propiciam, de maneira que sua violação gera sanções.

Assim, ao ampliar o espaço em que ocorre a socialização política, de forma a incluir experiências coletivas relevantes - como a deliberação acerca do orçamento municipal, ou as ações estatais na área da saúde - envolvendo na discussão cidadãos considerados individualmente, partidos políticos, associações,

\footnotetext{
${ }^{6} \mathrm{O}$ "mundo da vida" é um termo utilizado por Habermas para se referir às práticas comunicativas e argumentativas da vida privada e da cultura, sendo considerado o "habitat" natural dos espaços societários das instituições sociais como a família, associações de bairro, comunidades de base, sindicatos e das organizações culturais, artísticas e científicas. Este "mundo da vida" está em oposição ao "mundo sistêmico", o qual se orienta pela ação instrumental ou estratégica, sob a forma de ação técnica que aplica, racionalmente, meios para a obtenção de fins, através do uso do poder econômico e político. O objetivo central do "mundo sistêmico" é o êxito, o sucesso, a dominação (Habermas, 1987).
} 
grupos sociais diversos, etc, é possível que se estreite ainda mais o vínculo entre a formação de disposições subjetivas e as instituições deliberativas, tornando a relação de causalidade entre ambas bem mais complexa.

Assim sendo, em fóruns de deliberação com diversos grupos, pode-se desenvolver a tolerância das pessoas e torná-las mais sensíveis a valores e práticas democráticos como a liberdade de expressão, os sistemas eleitoral e partidário, além de deixá-las mais confiantes no próximo e nas instituições. Estas mudanças de preferências podem ser analisadas pelas teorias do capital social e da cultura cívica. 


\section{1 - Modificação na cultura política e geração de capital social}

Há tensos debates nas ciências humanas no que diz respeito à modificação da cultura política das sociedades. Em 1963, Almond e Verba, em seu já clássico The Civic Culture, afirmaram que havia uma revolução política ocorrendo no mundo democrático, revolução à qual alcunharam de explosão participativa (Almond $e$ Verba, 1963, $p$ 02). A premissa é a de que uma forma institucional democrática de participação política, para ser eficiente, necessita de uma cultura política a ela consonante.

Por cultura política os autores compreendem as orientações políticas das pessoas, como sua atitude acerca do sistema político e suas instituições, e como este sistema político é cognitivamente internalizado e apreendido como sentimentos e avaliações das pessoas. A cultura política pode ser observada através de modelos de orientação política do conjunto de pessoas de determinado país (ibid, $p$ 12-15).

O termo orientação foi utilizado no sentido de aspectos que podem ser internalizados pelas pessoas em suas relações com instituições ou outras pessoas, de forma que se podem classificar tipos de orientação em: i) orientação cognitiva, que são os conhecimentos ou crenças acerca do sistema político, com suas respectivas regras e incumbências, inputs e outputs; ii) orientação afetiva, ou sentimentos sobre o sistema político, suas regras, staff e desempenho; iii) orientação avaliativa, que são os julgamentos e opiniões acerca de objetos políticos que envolvem a combinação de valores padronizados e críticos com informações e sentimentos.

Há, também, orientações políticas voltadas para o indivíduo como ator político, para sua consonância acerca das normas sociais e de suas obrigações enquanto agente político, e em relação à sua percepção de competência política. As orientações das pessoas, a partir desta perspectiva, podem se dar acerca de sistemas de uma maneira geral (como corpos executivos, legislativos ou burocráticos); sobre as pessoas incumbidas de executar as regras (monarcas, 
presidentes, administradores, etc); ou a propósito de alguma política pública específica.

Dados estes tipos de orientações políticas, os autores puderam estipular tipos de cultura política a eles subjacentes. O tipo de cultura política paroquial apresenta uma freqüência nula, ou muito próxima a isso, em relação às preocupações das pessoas em se tratando do sistema como um todo. Neste tipo de sociedade não há diretrizes políticas específicas, e as orientações políticas não são separadas das sociais ou religiosas. Já países que apresentaram uma cultura política de sujeição, demonstraram uma freqüência maior de orientações acerca de diferenciados sistemas políticos, bem como a diferentes resultados destes sistemas. Contudo, suas orientações para mecanismos de ingresso nos sistemas políticos aproximaram-se de zero. Já a cultura política participativa apresentou-se como aquela na qual membros da sociedade demonstraram-se explicitamente orientados para o sistema como um todo, levando em consideração suas dimensões administrativa e política, e as atitudes e avaliações das pessoas tenderam para a participação política e para a avaliação crítica das situações.

Vale lembrar que estes são tipos ideais de cultura política, e que eles foram verificados de maneiras mistas entre si. Ao se introduzirem elementos de uma cultura política em outra, elas podem se adaptar - por exemplo, uma sociedade de orientação paroquial pode se adequar quando orientações mais especializadas entram em cena. Esta heterogeneidade cultural permite afirmar que os casos encontrados demonstraram-se misturas entre todas as orientações (participativa, de sujeição e paroquial).

Deve-se ressaltar, ainda, que uma cultura política coaduna com a estrutura política de um país, como lembram os autores:

"In general, a parochial, subject, or participant culture would be most congruent with, respectively, a traditional political structure, a centralized authoritarian structure, and a democratic political structure” (ibid, p 20). 
Desta forma, pode-se afirmar que uma cultura cívica é aquela que sustenta orientações políticas participativas, nas quais o indivíduo, além de orientado para os mecanismos de ingresso no sistema político, tem conhecimento dos processos e estruturas do sistema de maneira generalista. De um cidadão de uma cultura cívica é esperado que seja envolvido nas questões políticas, racional em suas aproximações com a política, bem informado, com alto grau de confiança interpessoal, bem como se espera que esteja alocado em um sistema político democrático.

\section{Capital Social}

Contemporaneamente, ao retomar o tema de cultura política, Robert Putnam cunhou o termo capital social, o qual traduz a existência de redes sociais de relacionamentos que conectam as pessoas e, em um processo de retroalimentação, são pautadas e têm por frutos normas de reciprocidade e confiança generalizada. ${ }^{7}$

Os termos capital social e cultura cívica são muito próximos, tendo o capital social um aspecto coletivo e um individual. No caso do capital social individual, as conexões individuais favorecem os interesses das pessoas que as têm, e o indivíduo pode conseguir um emprego, um tipo de auxílio, ou vantagem pessoal qualquer. Não se desenvolvem apenas benefícios materiais imediatos neste tipo de capital social, mas há a possibilidade de que se consigam benesses para a ajuda humanitária, por exemplo.

\footnotetext{
${ }^{7}$ O termo capital social foi utilizado, pela primeira vez, por Hanifan, em 1920, para se referir às substâncias tangíveis que são levadas em consideração na vida cotidiana das pessoas, como amizade, simpatia, e intercurso social entre pessoas, o que mantém a sociedade unida. Em seguida, o termo foi utilizado por Loury (1977), Bourdieu (1983) e por Coleman (1988, 1989), para designar o conjunto de recursos inerentes às relações familiais e na organização social. Este capital social, segundo estes autores, é útil para o desenvolvimento cognitivo e social de crianças e jovens. A face de bem público do capital social foi debatida pela primeira vez em 1990, por Coleman (Foundations of Social Theory). Para detalhes acerca do histórico e diversas concepções de capital social ver OSTRON, Elinor. A social perspective on social capital: social capital and collective action. 2001.
} 
No caso do capital social coletivo, pode-se observar que uma comunidade bem conectada é capaz de adquirir ganhos gerais, como a geração de normas coletivas de reciprocidade, a exemplo da norma que preconiza: "se não for ao funeral de alguém, não irão ao seu". Mas a norma de reciprocidade mais eficiente neste tipo de comunidade é a "norma de reciprocidade generalizada", na qual se faz algo por alguém não se esperando nada específico em troca. Tal norma pode ser atingida em sociedades nas quais há freqüente interação entre diferentes tipos de pessoas que têm confiança mútua. Até mesmo os capitais econômicos e/ou políticos, quando embebidos em densas redes de capital social, incentivam a diminuição do oportunismo e mau-caratismo (Putnam, 2001).

O capital social pode tomar diversas formas, como a família, a catequese, um grupo de pôquer, etc., e pode ser dividido em dois grupos. O primeiro, chamado de capital social bridging, ou inclusivo, funciona no sentido de conectar grupos a valores externos aos seus e a difundir informações. Este tipo de capital social pode tomar a forma de movimentos de direitos civis, grupos de assistência social e organizações religiosas ecumênicas. O segundo tipo, o capital social bonding, ou exclusivista, se presta a definir um tipo específico de reciprocidade para mobilizar solidariedade, formando densas redes de capital social e psicológico para grupos específicos, gerando um alto grau de lealdade interna, bem como alta incidência de antagonismos com grupos externos. Tem-se por exemplos deste tipo de capital social as organizações fraternais, grupos femininos de oração e os grupos étnicos.

Apesar destes tipos de capital social serem intercambiáveis, o segundo tipo tem mais propensões a gerar más conseqüências coletivas, como sectarismo, etnocentrismo e corrupção, além de auxiliar a erigir formas de associações como a Ku Kux Klan e a máfia italiana, por exemplos.

A tolerância, o otimismo e a confiança generalizada são indicadores que apontam a propensão de os indivíduos serem mais predispostos a envolverem-se em distintas formas de ação coletiva, porque são mais abertos à interação com estranhos (Putnam, 1999; 2001). A tolerância política é um sinal de que um indivíduo aceita diferenças de pontos de vistas e respeita posições e preferências 
contrárias às suas. Um indivíduo tolerante busca conciliação e aceita conviver com visões de mundo conflitantes. Ambas as características são importantes para quem participa em formas de ação coletivas. Pessoas otimistas quanto ao futuro também se apresentam mais propensas a envolverem-se em movimentos e grupos sociais, pois também tendem a ver outras pessoas de maneira positiva.

Para adeptos desta linha teórica, a confiança está associada ao bom funcionamento das instituições democráticas, e ao bom convívio social. O conceito é de fundamental importância pelo fato de que é através dela que as pessoas enfrentam incertezas e imprevisibilidades decorrentes da crescente complexificação da vida, característica do mundo globalizado e das sociedades de massas. Contudo, para confiarem, as pessoas precisam ter a capacidade de prever o comportamento do outro, bem como ter clareza acerca das regras e normas que balizam as instituições que afetam sua vida (Moisés, 2005, p 11).

\section{A questão da confiança}

Explorarei com mais detalhes a questão da confiança generalizada, por considerála ingrediente fundamental em qualquer concepção de engajamento público. Neste sentido, ao se avaliar o exemplo banal de uma ida ao médico, quem garante que este médico pode curar? Ou até mesmo, que aquela pessoa que atende os pacientes seja, de fato, um médico, ou um bom médico? Qual a segurança que se tem para andar em ruas vazias e desertas à noite? Por que confiar nas pessoas?

A confiança é ingrediente necessário para o funcionamento das sociedades modernas em toda sua complexidade e diferença, sendo o substrato da fraternidade, auxiliando a manter os homens juntos.

Confiança envolve julgamento, às vezes implícito, e conseqüente aceitação frente a uma possível situação de vulnerabilidade, ao se permitir que o "outro" exerça poder discricionário sobre determinado bem ou situação. Desta forma, quando 
alguém confia, espera que a confiança que está depositando não seja abusada por parte do confiado.

Mark Warren afirma, na introdução de "Democracy and Trust":

"a society that fosters robust relations of trust is probably also a society that can afford fewer regulations and greater freedoms, deal with more contingencies, tap the energy and ingenuity of its citizens, limit the inefficiencies of rule-based means of coordination, and provide a greater sense of existential security and satisfaction" (Warren, 2001, p 06).

É mais problemático, todavia, imaginar-se uma situação de confiança generalizada em sociedades complexas como as contemporâneas, nas quais seus habitantes sequer entabulam conversações, apresentaram-se mais vulneráveis e têm poucas chances de monitorar suas interações mas que, paradoxalmente, podem propiciar expansão das condições de vida, pluralização e mobilidade.

Uma situação de vulnerabilidade pode ser superada pela confiança generalizada. $O$ fato de se confiar em estranhos é uma possibilidade de se falar em ações cooperativas que visem a objetivos comuns (o que extrapola o desejo individual dos envolvidos). Esta confiança funciona como amálgama social, relacionado aos direitos de cidadania, enraizados sócio-culturalmente e de implicações normativas. Afirmar isto significa que uma situação de confiança não envolve, exclusivamente, cálculos racionais. Isto significa dizer que não há situação pura na qual o confiante conhece todas as motivações do confiado a ponto de antecipar os interesses do segundo e supor que os interesses deste sejam considerados na ação (Moisés, 2005, $p$ 06).

Neste sentido, Clauss Offe afirma que as imagens e crenças que os indivíduos compartilham acerca das normas que modelam sua vida social têm papel fundamental para o desenvolvimento da confiança (Offe, 2001). 


\section{Confiança, Instituições e Cultura}

Desta perspectiva teórica, as instituições desempenham papel fundamental como facilitadoras da confiança generalizada. Segundo Offe, as instituições se baseiam em "modos formais de coordenação", a exemplo das relações financeiras (que coordenam a ação dos participantes no mercado), de autoridade (que legitimam os constrangimentos do uso da força e ação dos cidadãos através do judiciário e executivo), e de conhecimento (que promovem atenção e cuidados com os problemas correntes e futuros dos atores sociais). Mas, também dependem de seus "modos informais de coordenação", que operam por meio de comprometimentos que resultam de imagens e crenças acerca da vida, que membros das sociedades modernas compartilham sobre membros de outras comunidades, bem como as ações que se seguem a estas crenças.

Estes modos informais desafiam os modos formais por não serem estrategicamente manipuláveis ou previsíveis, assim como não podem ser ordenados em um currículo formal, estando presentes ou ausentes em um contexto social, mas não podendo ser facilmente criados através de ação estratégica (Offe, 2001).

Esta premissa remonta às preferências e inclinações comportamentais dos outros em termos de seu preparo para contribuir, cooperar e negar o egoísmo, oportunismo e cursos hostis de ação.

As imagens e quadros cognitivos que as pessoas antecipam como prováveis reações dos outros irão constranger políticas na micro-esfera, bem como estratégias de investimentos na macro-esfera:

"Seen from this angle, the superstructure of the political economy and the performance of its governing institutions seem to be based upon the soft underpinnings of images, perceptions, and anticipations that people form of each other" (Offe, 2001, p 45). 
A grande hipótese posta por Offe neste momento é a de que a qualidade das ordens institucionais é que determina os recursos morais e cognitivos de confiança que inspiram a cooperação. É a ordem institucional que gera o comprometimento do indivíduo, baseado na antecipação de que os demais participantes da comunidade política também se sentem comprometidos e compartilham dos mesmos valores.

Desta forma, a confiança é vista como a premissa com a qual indivíduos ou atores coletivos entram em interação com outros atores. Esta confiança remonta às preferências e inclinações comportamentais dos outros em termos de seu preparo para contribuir, cooperar e negar o egoísmo, oportunismo e cursos hostis de ação.

Alguns autores, baseados em assertivas da escola da escolha racional ${ }^{8}$, se opõem a esta perspectiva teórica, afirmando que o que nos levaria a cooperar e interagir socialmente é um sistema de 'checks and balances' operado pelas instituições.

Offe nos lembra, entretanto, que

"institutions are held to have built-in-self-correcting mechanisms that rule out major deviations from the expected and known course of operation. Institutions are being counted upon because they are durable and can be taken for granted once they are put in place. Thus the impersonal operation of self-sustaining mechanisms makes personal trust relations both impossible and dispensable. What can be taken for granted (almost like the force of gravity) does not need to be trusted ... Institutions are incomplete and ambiguous (at least "at the margin"), and they are contested (grifos do autor - Offe, 2001, p 66).

8 Para eles a confiança generalizada seria impossível em sociedades modernas devido à mobilidade das pessoas e a contingência de relações contratuais, somado ao fato das pessoas não se conhecerem por muito tempo (o que impede a confiança baseada em experiências de longo tempo), e a falta de interação continuada entre as pessoas que possibilite a antecipação do comportamento do "outro". Ver: Analyzing politics: rationality, behavior, and institutions / Kenneth A. Shepsle, Mark S. Bonchek. W.W. Norton, 1997. 
Duas mostram-se as objeções básicas acerca deste dilema institucionalista. A primeira se refere à idéia de que as regras institucionais não têm uma natureza abrangente a ponto de esgotarem situações, não servindo para todas as contingências e emergências. Isto significa dizer que estas regras estão sempre à disposição de controvérsias e de substituições, mesmo porque precisam, de tempos em tempos, serem ajustadas para que se mudem parâmetros. ${ }^{9}$ Como segunda objeção, o autor argumenta que as instituições não são convenções, que teriam características próprias; ao contrário, as instituições estabelecem padrões do que é precário. ${ }^{10} \mathrm{Em}$ contraste, elas regulam e contestam os meios, as distribuições de valores e insumos, além do fato de controlarem, de acordo com suas finalidades e recursos, as esferas de ação dos atores. Como conseqüência, a confiança nos anônimos mecanismos institucionais é justificada pela complacência voluntária daqueles atores que aplicam suas leis, bem como pela confiança daqueles atores que são supervisionados e fortalecidos pelas suas regras.

O que faz então com que as pessoas se submetam às instituições? Segundo Weber, e sua clássica tipologia tripartite de legitimidade, esta submissão ocorre devido à tradição, ao carisma ou à força racional-legal das leis.

Ao focarem-se as leis, especificamente, estas não são auto-executoras de si, e podem-se levantar alguns pontos duvidosos sobre sua capacidade de gerar confiança (pondo em xeque a imparcialidade e a justiça de suas normas e procedimentos). O potencial de normas institucionalizadas (leis) de gerarem confiança interpessoal pode ser posto em dúvida pelo fato de que estas leis foram feitas, mas podem ser mudadas. Outro ponto é o de que o impacto concreto destas leis depende do staff administrativo do executivo do Estado, o que dá margens para que uma possível aquiescência a estas leis seja proveniente do interesse de quem as utiliza e da discrição e resistência a tentações oportunistas

\footnotetext{
${ }^{9} \mathrm{~A}$ Constituição Federal é um exemplo, por precisar ser adicionada e/ou revista por emendas constitucionais e medidas provisórias.

${ }^{10}$ Convenções são estritamente auto-suficientes e ninguém tem incentivos para violá-las, bem como ninguém espera ninguém para ter incentivo de nelas estar.
} 
de quem as opera. Pode-se, ainda, levantar um terceiro ponto: complacência pode ser função da avaliação individual do ator acerca da probabilidade que este julga que todos os outros têm de estarem motivados a colaborar e não a desertar.

A questão, ao fim e ao termo, é esta: são as qualidades substantivas das instituições e sua capacidade de gerar consenso que determinam seu sucesso na agregação de lealdades daqueles aos quais suas ações supostamente regulam. Desta maneira:

\begin{abstract}
"institutions ... are endowed with a spirit, an ethos, an implicit moral theory, and ideé directrice, or a notion of some preferred way of conducting the life of the community ... it is this implied normative meaning of institutions and the moral plausibility I assume it will have for others which allows me to trust those that are involved in the same institutions - although they are strangers and not personally known to me ... its evidence and moral compellingness, that leads "them" to share with 'me' a commitment to the norms and values represented by the institutions and thus transform then, my anonymous fellow citizens into trustworthy and actually trusted "compatriots'" (Grifos do autor - Offe, 2001, p 70).
\end{abstract}

Isto se deve ao fato de que atitudes e normas constituem um equilíbrio de mútuo reforço. As instituições de cunho cooperativo, por exemplo, requerem aptidões e confianças interpessoais. Mas essas aptidões e essa confiança são mutuamente inculcadas e reforçadas pela colaboração organizada. As normas e os sistemas de participação social contribuem para propósitos coletivos e são, por sua vez, 
reforçadas, e reavaliadas, pelas crenças, valores e atitudes destas coletividades. "Nesse contexto, o debate do tipo 'o ovo ou a galinha' sobre cultura versus estrutura é essencialmente infrutífero. Mais importante é entender por que a história facilita certas trajetórias e obstrui outras" (Putnam, 2001, p 190).

Todavia, ao empreender uma analise histórica na Itália, e ter afirmado que o Norte daquele país tinha melhores instituições democráticas do que o Sul devido a seu vigoroso histórico de formação e manutenção de capital social, Putnam não obteve consenso entre os pesquisadores culturalistas (Ostrom, 1990; Ostrom et all, 1994; Harris e De Henzio, 1997; Ostrom, 2001).

\section{Geração de capital social e modificação na cultura política}

Para se falar em cultura cívica e capital social, deve-se apreciar os processos de formação social de determinada sociedade. A sociedade britânica, estudada por Almond e Verba, pode ser um exemplo. Segundo estes autores, este país é detentor de cultura cívica. Este padrão cultural, argumentam eles, se desenvolveu devido ao fato de, historicamente, mesclou-se modernidade e tradição na Grã Bretanha, quando ocorreu seu processo de secularização e o país separou-se da igreja católica de Roma, tendo principiado um processo de tolerância e diversidade religiosa.

A emergência de uma classe mercantil, mesclada a uma aristocracia com poder local, incluiu ambos estamentos nos riscos dos processos de trocas mercantis. Desta forma, a Grã-Bretanha iniciou a Revolução Industrial com uma cultura política entre suas elites que permitiu a rápida assimilação das mudanças sociais que se dariam nos séculos XVIII e XIX. Estas mesclas de poderes permitiram a emergência de uma cultura política pluralista, com tons tradicionalistas e progressistas, baseada na comunicação e na persuasão. As instituições políticas bretãs, forjadas envoltas neste manto cultural, incumbiram-se de difundir os valores e normas ideológicas da democracia, encarregando-se de fazer a 
manutenção de uma população civicamente ativa, que participa dos negócios públicos, com alto grau de informação sobre a coisa pública e com elevado senso de civismo (Almond e Verba, 1963).

Já o caso da Itália, estudada por Putnam em meados da década de 1990, foi utilizado para responder a pergunta de por que alguns governos democráticos têm bom desempenho e outros não. Este país foi escolhido por ter passado, na década de 1970, por uma reforma política e um processo de descentralização que desenhou suas atuais 20 regiões administrativas, tornando-as praticamente idênticas e com os mesmos poderes. Ainda assim, o Norte da Itália demonstrou-se mais eficiente - em se tratando de governança democrática, e possuidor de vínculos horizontais de capital social - em relação ao Sul.

Há, ainda, outra diferença entre a duas regiões. Esta está associada de maneira fundamental à proteção dos direitos republicanos, quais sejam, os direitos que cada cidadão tem de que os interesses públicos sejam públicos de fato, e não capturados por interesses privados. Esta preocupação está diretamente vinculada ao tema anterior, o dos valores cívicos, uma vez que no Sul da Itália se observaram distorções de comportamentos públicos, leiam-se cívicos, como a corrupção, o nepotismo e o corporativismo.

A explicação para tais diferenças, segundo Putnam, está fundamentada em fatores históricos. Ao saírem das brumas da Idade Média, no século XI, o colapso pela qual a então península que viria a ser a Itália estava passando teve fim, em seu lado Sul, pelo estabelecimento de um poderoso governo central, fortemente constituído nas tradições bizantinas e árabes. Em oposição, no Norte, onde malograram todas as tentativas de retorno ao poder imperial, prevaleceu, quase que inteiramente, o princípio da autonomia local (Putnam, 2001, p. 133).

Em outra obra polêmica, Bowling Alone, Putnam confirmou sua posição de que capital social é de difícil desenvolvimento, devido a seu caráter estrutural. Contudo, e diferentemente do capital econômico, não deve ser poupado, pois, quanto mais utilizado, mais o capital social se desenvolve. Estes argumentos 
foram corroborados por estudos acerca do capital social estadunidense, que após efervescência nas décadas de 1960/70 devido aos movimentos feminista e negro, principalmente, experimentou acentuado declínio devido a múltiplos fatores: a) ao advento da jornada familiar dupla, quando ambos os pais de família têm carreiras profissionais fora de casa, dedicando menos tempo à família; b) um acentuado processo de suburbanização; c) o aumento da quantidade de tempo gasto com entretenimento eletrônico; e, finalmente, mas o principal fator, d) uma forte mudança geracional, os filhos e netos das gerações fortemente engajadas em reivindicações pelos direitos civis apresentaram-se menos participativos (Putnam, 1999).

A partir de experiências históricas em diversos contextos, há um autor que analisa a herança cultural do Brasil. José Murilo de Carvalho afirmou que, ao proclamar sua independência de Portugal, em 1822, o país herdou uma tradição cívica "pouco encorajadora", devido às condições de nossa colonização, que exterminou pela guerra, escravização ou doença, milhões de povos seminômades que por aqui habitavam. Este fato, somado à finalidade da colonização, de caráter meramente comercial, colocou a recém conquistada terra na condição de empreendimento comercial.

Estas características marcaram este Brasil e não contribuíram para um ambiente propício à cidadania, "os escravos não eram cidadãos, não tinham os direitos civis básicos à integridade física [...], à liberdade [...] e à própria vida [...] existia uma população legalmente livre, mas a que faltavam quase todas as condições para o exercício dos direitos civis [...] e em direitos sociais ainda não se falava, pois a assistência social estava a cargo da igreja e de particulares" (Carvalho, 2002, pp 20-24).

A tese de Carvalho é a de que, ao contrário da Inglaterra ${ }^{11}$, no Brasil os direitos políticos apareceram primeiro, seguidos pelos sociais, e, finalmente, pelos civis -

\footnotetext{
${ }^{11} \mathrm{Na}$ clássica tese de T.H. Marshall, de que na Inglaterra, ao longo de três séculos, os direitos civis surgem primeiro, sendo seguidos dos políticos e dos sociais. Ver MARSHALL, T.H. Cidadania, classe social e status.
} 
todos com expansões e retrações, sendo ora afirmados, ora revogados. Segundo ele, isso impediu o desenvolvimento de uma cultura democrática.

Esta corrente histórica do culturalismo político, que apresentei até então, foi criticada por diversas razões, desde sua primeira tentativa sistemática de aplicação por Gabriel Almond e Sidney Verba em The Civic Culture. Esta obra foi criticada por seu "etnocentrismo ocidentalizante" (Pateman, 1989) e por sua adesão a um conceito minimalista de democracia, além de pressupor a existência de uma cultura política homogênea em cada sociedade.

As obras de Putnam (1999 e 2001), também foram criticadas por várias razões, três delas as principais: i) suas interpretações acerca da história medieval italiana são superficiais e generalistas; ii) a apresentação dos fatos históricos torna o capital social um produto determinista e anacrônico; e iii) ele confundiu prática democrática com performance política: se a confusão for desfeita, o capital social tornar-se-ia produto da relação entre performances governamentais e atores com interesses cívicos, e não a causa da atividade democrática. ${ }^{12}$

Assumindo que a cultura política de comunidades possa ser modificada, autores como Cristina Rojas, Richard M. Locke, José Álvaro Moisés e Tendler e Freedheim, baseados em estudos empíricos, consideraram que a cultura de determinadas sociedades foi modificada, ou está em processo de mudança, e que estas modificações dependeram das mudanças institucionais que foram tomadas visando a esta finalidade.

Locke, após apontar as deficiências das escolas sociológica e econômica no que tange à criação e desenvolvimento de cultura cívica e capital social, ${ }^{13}$ afirma que

\footnotetext{
${ }^{12}$ Ver Sidney Tarrow. Making Social Work Across Space and Time. The American Political Science Review, vol. $90 \mathrm{n}^{\circ} 02$.

${ }^{13}$ Segundo o autor: "First, its conception of the underlying factors sustaining trust is static. Second, its view of how trust is generated and sustained from a short-list of favorable conditions is mechanistic. Finally, and as a result of the first two problems, the literature on trust is overly pessimistic about the possibilities of creating trust in contexts where the favorable conditions and/or prerequisites supposedly underlying trust not exist". LOCKE, R. M. 2001. Building Trust. Artigo apresentado no "Annual Meetings of the American Political Science Association". San Francisco.
} 
para que se possam edificar redes de confiança recíprocas se faz necessário que haja um processo que misture ações auto-interessadas dos atores, com políticas governamentais apropriadas e mecanismos de "autogoverno" das associações civis envolvidas.

O autor cita o exemplo da região do Mezzogiorno, na Itália, onde os produtores de mussarela de búfala tinham um problema com a originalidade de seus queijos, que devido à elevada qualidade começaram a ser falsificados. Os produtores uniram-se e criaram o 'Consorzio di Tutela di Mozzarella di Bufala Campana', e ganharam um selo de autenticidade do governo regional, distribuído pelo próprio consórcio.

Já Cristina Rojas, ao analisar os três primeiros governos locais de Bogotá, após o processo de descentralização desenvolvido pelo governo central da Colômbia a partir dos idos de 1990, convenceu-se de que confiança, cooperação e reciprocidade puderam se desenvolver a partir de ações governamentais bem conduzidas.

Ela argumentou que na administração 1994-97, de Antanas Mockus, o Estado forneceu ferramentas para a auto-regulação dos cidadãos ${ }^{14}$, e ampliou o diálogo entre governo e população por meio de campanhas publicitárias para economizar água. A segunda gestão, de 1998-2001, empenhada por Gustavo Peñalosa, reorganizou o espaço público, abrindo $600.000 \mathrm{~m} 2$ de espaços verdes (parques e praças), onde a pessoas podiam se encontrar e conversar.

Também foram desenvolvidos fóruns de consulta popular sobre o orçamento municipal, com o slogan 'recursos públicos, recursos sagrados'. Ainda na política fiscal, o valor do imóvel foi vinculado à declaração espontânea do proprietário sobre o valor do bem imóvel no ato da cobrança dos impostos, o que teria gerado uma noção coletiva e pública de valor. ${ }^{15}$

${ }^{14}$ O governo implementou um sistema de placas de trânsito, que pedestres ou condutores mostravam, publicamente, condenando ou aprovando atitudes alheias, por exemplo.

${ }^{15}$ Como resultado das políticas, Rojas mostra indicadores como o total da arrecadação de 
Um estudo conduzido em 1994 por Tendler e Freedheim, a respeito do Programa Agentes de Saúde, no Ceará, se propôs a estudar os efeitos da descentralização do sistema de saúde, e teve por parâmetros os fundamentos teóricos do capital social. ${ }^{16}$ A conclusão do trabalho destas pesquisadoras foi a de que o bom desempenho do programa no Ceará foi resultado do caráter público e centralizador da política de saúde. Isto se deveu ao posicionamento do governo estadual no enrijecimento do processo de seleção dos agentes comunitários de saúde, o que aumentou a resistência da sociedade ao clientelismo, e fortaleceu a autonomia dos agentes em relação aos políticos tradicionais. Pari passu, as propagandas institucionais veiculadas na mídia encorajavam a população à rejeição de práticas clientelísticas, o que regenerou a aura do poder público, visto, até então, como foco principal de corrupção e manipulação. Com uma política pública bem elaborada, a confiança nas instituições públicas aumentou, o que facilitou a geração e manutenção de redes de reciprocidade e o sentimento cooperativo. Dois fatores de sucesso foram relacionados aos agentes: a) eles eram membros integrantes das comunidades, o que facilitou seu conhecimento real acerca das demandas da população local, e b) e por terem se apresentado como parceiros integrantes da administração pública.

Em outro estudo nacional, e mesmo tendo afirmado que a consolidação democrática é um longo processo, José Álvaro Moisés julgou que a cultura política brasileira está em mudança. Isto se deveu a quatro fatores fundamentais: i) a luta contra os constrangimentos políticos e legais à atividade política durante o período ditatorial no Brasil, somado à intervenção do Estado em associações da sociedade civil, chamaram a atenção desta para as virtudes da democracia; ii) durante o período ditatorial, as elites nacionais conviveram com um sistema político semi-

impostos prediais (similar a nosso IPTU), que subiu. Voluntariamente, $10 \%$ a mais da população passaram a pagar seus impostos. O número de homicídios por ano caiu de 4.452 em 1993 para 1.993 em 2001. O número de acidentes de trânsito decresceu de 1.387 casos em 1994 para 834 ocorrências em 2000; e os conflitos jurídicos passaram a ser resolvidos de maneira pacífica, como o caso dos menores infratores, que passaram a ser educadores sociais, induzindo as pessoas a utilizarem a faixa de pedestres, as passarelas, e, também, auxiliando como guias em livrarias públicas.

${ }^{16}$ Tendler, J. \& Friedhein, S. Trust in a Rent-Seeking world: health and government transformed in northeast Brazil. World Development, vol. 22, nº 12. 
competitivo, com realização periódica de eleições, o que aprofundou a dissidência entre as elites; iii) o início da abertura política coincidiu com as crises econômicas internas e externas (1972-73), o que aumentou a insatisfação entre o empresariado; e iv) quase duas décadas de modernização alteraram a macromorfologia da sociedade, aumentando a divisão do trabalho, concentrando populações em áreas metropolitanas, e provocando intensa mobilização sóciopolítica.

Todos estes fatores contribuíram para uma requalificação cognitiva de parcelas substantivas da população (entre suas elites e massa), gerando novas expectativas e demandas, mais complexas e volumosas, em relação ao papel do Estado e do poder público (Moises, 1995, pp 107-109).

Segundo Moisés, se está formando uma opinião pública mais atenta aos processos políticos, há um maior reconhecimento das instituições democráticas "per se", e existe uma adesão normativa da população à democracia. O autor conclui que "a valorização da democracia pelos públicos brasileiros de massa representa uma base de apoio atitudinal indispensável para surgimento de novos comportamentos democráticos" (Moisés, 1995, p. 266).

Fundamentados por argumentos como estes, organizações internacionais de fomento como o Banco Interamericano de Desenvolvimento (BID) e o Banco Mundial, assumem a diretriz normativa de que a geração de capital social estimula a diminuição da pobreza e torna ações governativas mais eficientes e eficazes. Desta forma, políticas públicas de desenvolvimento de capital social tornaram-se condição sine qua non para investimentos em projetos de incremento local em países em desenvolvimento.

Este debate sobre criação de capital social tem por um de seus temas centrais, como sustentei anteriormente, a relação de causalidade entre as dimensões cultural e institucional da vida política. Assumindo que estas esferas mantêm relações de retroalimentação, esta discussão deve partir de um patamar que 
considere a heterogeneidade tanto das pessoas, quanto das instituições que compõem a sociedade.

Assim, baseado na possibilidade de geração e modificação de cultura cívica e capital social através da participação e deliberação populares, investigou-se as diferentes relações entre diversas instituições e a cultura política das pessoas que delas fazem parte, tendo em vista as especificidades das instituições a que pertencem.

Para tanto, parto de um conceito de democracia que tem como ponto crucial a inclusão de cidadãos e sua participação continuada na deliberação dos assuntos de interesse coletivo. Um regime que não se limita a regras procedimentais de competição entre interesses diversos, mas que inclui uma dimensão normativa, ligada a valores republicanos, que deve ser partilhada por todos os integrantes da comunidade política. Neste ambiente, a deliberação é, ao mesmo tempo, fator de expressão de interesses e de criação de capital social e cultura cívica. Em outras palavras, acredito que haja relação entre a participação em determinadas instituições e o surgimento de valores, percepções e práticas políticas democráticas em seus membros. 


\section{Capítulo II - De Conselhos populares ao Estado: o aparecimento dos Conselhos Gestores de Saúde e os estudos empíricos sobre estes fóruns.}

A partir do processo de abertura política, em meados da década de 1980, o Brasil passou por um período de democratização em sua ordem política. Nesse contexto, setores da população que vinham se organizando se fortaleceram e buscaram canais mais visíveis de expressão para suas reivindicações. Isto ocorreu, inicialmente, através das Comunidades Eclesiais de Base (CEBs), dos clubes de mães, das Pastorais da Igreja Católica, das associações de bairros, dos grupos de educação popular, dos movimentos de carestia, sindicatos, partidos políticos, entre outros (Sader, 1988).

Já a partir do início da década de 1970, a visibilidade pública das reivindicações por direitos sociais e pelo fim do regime militar se vinha ampliando sensivelmente com o impulso dado pela reorganização do movimento sindical, em sua luta por autonomia em relação ao Estado.

As evidências, como aponta Eder Sader, eram inúmeras: "as votações recolhidas pelo MDB a partir de 1974, a extensão e as características de movimentos populares nos bairros da periferia da Grande São Paulo, a formação do chamado 'Movimento do Custo de Vida', o crescimento de correntes sindicais contestadoras da estrutura ministerial tutelar, o aparecimento das comunidades de base, as greves a partir de 1978, a formação do Partido dos Trabalhadores seriam manifestações de um comportamento coletivo de contestação da ordem social vigente" (Sader, 1988, p 30).

A enorme diversidade destes movimentos assumiu formas as mais diversas, que foram desde associações até movimentos rurais, como os sem-terra ou os movimentos de barragens, passando por movimentos de mulheres, comunidade de base da Igreja Católica, movimentos negros, sindicatos profissionais ou movimentos ecológicos, além do Partido Comunista Brasileiro (PCB), do Movimento Democrático Brasileiro (MDB), e novas organizações partidárias como 
o Partido dos Trabalhadores (PT), o Movimento Sanitário e agrupamentos pontuais como o MR8.

Sob o governo Figueiredo, decretou-se a anistia e a reforma partidária, em 1979. Esta reforma abriu espaço para a eleição direta de governadores e parlamentares de oposição, em 1982. (Doimo e Rodrigues, 2003, pp 102 a 105).

Em 1984 foi eleito Tancredo Neves, primeiro Presidente civil em 20 anos. Mas, devido a seu repentino falecimento, veio a ser substituído por José Sarney. Este processo marcou a abertura política do Brasil.

Em 1988, o Congresso Nacional consagrou uma nova Constituição. O modelo de democracia implantado no Brasil definiu e possibilitou a experimentação de novos procedimentos de gestão participativa das políticas sociais e dos Conselhos de Gestão de Políticas Públicas. De acordo com a Constituição, o Brasil é uma democracia representativa, com instrumentos de gestão direta e participativa.

A nova Carta Magna institucionalizou espaços de participação direta com a intenção de incentivar formas de socialização da informação e de experimentação que acomodassem a diversidade social em novos arranjos administrativos. Tais arranjos deveriam permitir processos argumentativos flexíveis e capazes de vincular atores diversos.

No bojo da multiplicidade de processos participativos que se instauraram no Brasil desde então estão os Conselhos Gestores de Saúde. Acerca destas instituições far-se-á uma breve incursão em seu histórico de desenvolvimento para, em seguida, apresentar-se os debates nacionais a respeito de seu funcionamento. 


\section{Movimentos Sanitarista e Populares e o processo de redemocratização}

Hoje, ao tratar-se do Sistema Único de Saúde (SUS), é corriqueiro se falar sobre seu caráter público, igualitário e universal, com controle popular. ${ }^{17}$ Outra peculiaridade do SUS é a existência de esferas de negociação entre governos federal, estaduais, municipais e sociedade civil, que se apresenta como uma prática na área desde há muito tempo. Estas características do sistema de saúde surgem com força na III Conferência Nacional de Saúde, em 1963, quando se começa a pensar uma reforma sanitária no país, visando-se à municipalização da assistência à saúde.

O movimento de reformulação do sistema de atenção à saúde no Brasil não se limitou a decisões tecnocráticas oriundas da burocracia estatal da década de 1970. Houve um processo de retomada e reformulação da crítica que se fazia ao sistema de saúde no período da democracia populista, antes do período militar, quando o Ministério da Saúde havia sido politizado por representantes da esquerda, particularmente do Partido Comunista Brasileiro (PCB).

Esta retomada ocorreu primeiramente nas faculdades de medicina (especificamente nos departamentos de medicina preventiva), em formação em diversos estados da Federação. Nesta época, final dos anos 1960, foi marcante a influência do pensamento crítico do argentino Juan César Garcia, sanitarista da

\footnotetext{
${ }^{17}$ Para a sociologia e a psicologia, o termo controle social designa os processos de influência do coletivo sobre o individual. Aplicados aos Conselhos, ele teve seu significado modificado, transformando-se em conceito operacional para designar o processo e os mecanismos de influência da sociedade sobre o Estado. Para tanto, a sociedade passa a ser identificada com o interesse geral e o Estado é tido como comprometido com interesses particulares. Assim, esta idéia de controle social que fundamenta os Conselhos carrega uma ambigüidade básica: por um lado projeta a idéia de um Estado neutro, passível de ser conduzido por segmentos que podem obter vantagens circunstanciais nos espaços decisórios. Por outro lado, tende a subestimar as possibilidades de autonomia e efetividade associadas à sua existência. Este ceticismo provém da concepção de um Estado não neutro e de aportes corporativistas. "Ambas situações extremas têm como base comum a visão instrumental dos Conselhos que, considerados 'braços' da sociedade, devem manter-se em posição externa ao Estado, seja para guerreá-lo, seja para vigiá-lo, seja para invadi-lo, podendo resultar numa perspectiva de controle social despolitizada e eventualmente inócua" (Carvalho, 1997, p 98). Mesmo com esta ambigüidade latente, o termo "controle social" permanece amplamente utilizado em documentos oficiais como leis e material de formação de conselheiros, além de apresentar-se usual entre as diversas categorias que formam os movimentos sociais que mantêm vínculos com questões do sistema de saúde.
} 
Organização Panamericana de Saúde (OPS) (Saddi, 2004, p 73). Suas idéias estimularam a utilização das ciências sociais aplicadas à saúde. No Brasil, esta prática foi definitivamente implementada com as publicações de $O$ dilema preventista, de Sérgio Arouca, e Medicina e sociedade, de Cecília Donnangelo (Escorel, 1998, p 19).

Sustentado a premissa de que a saúde e a doença na coletividade não podem ser explicadas exclusivamente por suas dimensões biológicas - uma vez que também são determinadas por processos de conformação social e histórica -, este movimento sustentou duas frentes de ação: uma política e uma social. Do ponto de vista social, profissionais recém formados em universidades como a UNICAMP e a USP começaram a realizar trabalhos comunitários nas regiões pobres de suas cidades.

Ao efetuarem este trabalho, estes jovens médicos transferiram conhecimento para a comunidade, exercendo um papel de intervenção para além da medicina curativa. Devido a isto, este movimento consagrou um processo de mudança no entendimento da população sobre o significado e alcance do que vem a ser público na saúde.

A face política do movimento pode ser evidenciada pelo fato de representantes deste movimento de saúde social terem começado a ocupar lugares de destaque nas Secretarias Municipais de Saúde quando, em 1982, a esquerda progressista do MDB assumiu prefeituras de municípios e governos de estados, e ganharam poder para barganhar posições no Ministério da Saúde.

Da perspectiva das iniciativas de cunho popular, clérigos e laicos identificados com a Teologia da Libertação e com as Comunidades Eclesiais de Base (CEBs), organizaram-se ao redor das paróquias locais, e deram força à noção de saúde como um direito a ser promovido pelo Estado. Tal ideário veio somado à forte noção coletiva de gerar mecanismos de participação popular, noção que priorizava a organização popular enquanto movimentos reivindicativos por melhoria de equipamentos médicos e de saneamento básico. 
Neste período, apoiados por Dom Helder Câmara (RJ), Dom Paulo Evaristo Arns (SP) e Dom Mauro Morelli (Baixada Fluminense), os movimentos populares de saúde foram adquirindo um caráter público de mobilização social e contestação ao regime militar, tendo por fundamento a reivindicação da saúde como um direito social. (Doimo e Rodrigues, 2003, p 98).

Em São Paulo, ainda sob a ditadura militar, "um fato emblemático da ação das forças de esquerda em torno da questão da saúde anunciaria o que viria a se reproduzir dez anos depois, por época da Constituinte: a junção da 'nova' esquerda e da 'velha' esquerda. Juntos, movimentos populares de bairro ligados à Igreja, de demais forças do chamado 'movimento popular', movimento médico ligado ao 'novo sindicalismo' e Movimento Sanitarista, hegemonizado pelo ainda proscrito Partido Comunista, promovem, nas dependências da FGV - Fundação Getúlio Vargas -, o primeiro grande 'Encontro por Melhores Condições de Saúde'. A partir dai, a defesa da saúde como direito reverberou aos quatro cantos do país, lado a lado ao clamor pela participação popular dos serviços públicos de saúde" (ibid, ibidem - grifos das autoras).

Neste momento, o Movimento Sanitário, liderado por profissionais como David Capistrano Filho, Eduardo Jorge, e Emerson Elias Merhy, propôs a criação do CEBES (Centro Brasileiro de Estudos de Saúde), com a intenção de formar um núcleo crítico de discussões sobre saúde pública. O principal intuito deste grupo era o de propor uma reforma no sistema de atendimento à saúde do Brasil, visando à universalização do atendimento e à integração da prática da medicina preventiva associada à curativa. Como narra Merhy, ao tratar do processo de criação do CEBES:

"Levamos a idéia para Sociedade Brasileira para o Progresso da Ciência (SBPC) de Brasília de 1976 e, numa reunião com 50 pessoas, percebemos que se tratava de uma vontade coletiva. Resolvemos então fazer um lançamento nacional desta idéia. Até dezembro de 1976 a idéia estava centralizada em São Paulo, mas depois de um ano já tínhamos 5 mil pessoas afiliadas. Esta sinergia prova que já havia um movimento favorável no país, tanto na academia quanto nas periferias. Este último era um movimento 
clandestino de esquerda, que se traduzia em movimento contra a ditadura. Tudo isso somava-se à tradição que já vinha dos anos 50/60 de fazer a crítica à política pública de saúde. Não éramos iguais, mas estávamos juntos em torno da luta pela democracia e pelo direito social”' (Saddi, 2004, p 75).

Estas pessoas discutiram, elaboraram e, em 1979, apresentaram pela primeira vez no $1^{\circ}$ Simpósio Nacional de Políticas de Saúde, em Brasília, um projeto denominado "Sistema Único de Saúde", que propunha a universalização do direito à saúde, integrando ações preventivas e curativas, e com fóruns de democrática participação popular.

Inspirados pela idéia, o governo federal reorientou algumas ações, lançando, ainda em 1979, o PIASS (Programa de Interiorização das Ações de Saúde e Saneamento), e, em 1980, o Prev-Saúde, que integrava os Ministérios da Saúde e Previdência.

A discussão do PIASS foi a porta institucional de entrada dos Sanitaristas no Ministério da Saúde, através da Secretaria Técnica de Apoio ao Grupo Executivo Interministerial (ST/GEIN). Assim, conformou-se o processo de participação política dos Sanitaristas, o qual se estenderia no ano seguinte, com a criação do Conselho Nacional de Secretários de Saúde, o CONASS.

Aquele projeto, o PIASS, contribuiu para estreitar o vínculo entre o Ministério da Saúde e os quadros políticos dos municípios e estados. Ademais, foi executado juntamente com várias experiências de saúde comunitária, voltadas para a implementação de uma rede básica de saúde nos municípios. Estes projetos eram levados a termo por Prefeituras sob o comando da oposição, o MDB.

Em 1982, implantaram-se as AIS (Ações Integradas da Saúde), que deram início formal à participação popular, fortaleceram a municipalização e propuseram a ação conjunta dos Ministérios do Interior, da Saúde, da Previdência e da Educação. 
A VII Conferência Nacional de Saúde teve por tema: $A$ instalação de uma rede básica de serviços de saúde, e trouxe para deliberação política a discussão acerca da extensão da cobertura da assistência à saúde. Esta conferência teve por fruto a nomeação de Eleutério Rodrigues Neto, sanitarista, para a diretoria do Departamento de Planejamento do INAMPS.

Esta nomeação teve importância estratégica para o Movimento Sanitário, pois significou a "abertura da instituição a novos quadros do movimento, pelo franqueamento de informações até então monopolizadas pelos estamentos burocráticos conservadores, pelo próprio avanço do processo político representado estrategicamente pelas [criação das] AIS" (Saddi, 2004, p 82).

Em março de 1986, com o fim da ditadura que ocorrera no ano anterior, o Congresso Nacional convoca a VIII Conferência Nacional de Saúde, com fundamental participação dos sanitaristas e dos Movimentos Populares de Saúde. Este evento tornou-se o mais importante da área da saúde.

Esta conferência foi marcada por seu caráter democrático, pela presença de milhares de delegados e representantes das mais diversas forças interessadas nas questões da saúde. A dinâmica processual deste encontro foi a de reunir debates em âmbito municipal, seguindo-se ao Estadual e culminando em uma discussão de rumos nacionais.

Desta conferência, a Comissão Nacional de Reforma Sanitária saiu com a incumbência técnica de "constituir-se no instrumento que viria a influir de forma determinante em dois processos que se iniciaram, concomitantemente, em 1987: um, no Executivo, a implantação do Sistema Unificado e Descentralizado de Saúde, o SUDS; outro, no Congresso Nacional, a elaboração da nova Constituição Federal" (MS, 2000, p. 62). 


\section{As conquistas institucionais na saúde}

Como fruto destes processos de participação, hoje se pode ler no artigo 198 da Constituição: "as ações e os serviços públicos de saúde integram uma rede regionalizada e hierarquizada e constituem um sistema único, organizado de acordo com as seguintes diretrizes:

1 - descentralização, com direção única em cada esfera de governo;

2 - atendimento integral, com prioridade para as atividades preventivas, sem prejuízo dos serviços assistenciais;

3 - participação da comunidade".

No terceiro item, o da participação social, deve-se apreender o conceito de controle social, bem como definição, acompanhamento de execução e fiscalização das políticas de saúde.

A Lei Orgânica da Saúde instaura duas formas de participação da comunidade: as conferências e os conselhos de saúde. As primeiras são fóruns amplos, onde se reúnem representantes da sociedade (usuários do SUS), profissionais de saúde, dirigentes, prestadores de serviços de saúde, parlamentares e afins, para, segundo o artigo $1^{\circ}$, parágrafo $1^{\circ}$ da Lei 8.142/90, "avaliar a situação da saúde e propor as diretrizes para a formulação da política de saúde" (ibid, ibidem).

As conferências são nacionais, de 04 em 04 anos e estaduais e municipais, de 02 em 02 anos. A nacional já está em sua $12^{\mathrm{a}}$ versão, tendo a oitava CNS, em 1986, desempenhado papel primordial, pois seu relatório final serviu de base para o capítulo de saúde da Constituição Federal. A nona CNS, realizada em 1992, exigiu

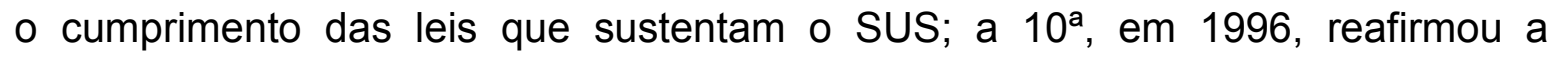
universalidade, a descentralização e a gratuidade dos serviços de saúde, além de ter exigido a efetivação de espaços para a participação popular e controle social no SUS. A $10^{a}$ edição também elaborou a Norma Operacional Básica 01/96, a qual instaurou o Piso de Atenção Básica - PAB - e estabeleceu dois planos de 
gestão municipais para a saúde, a saber: Gestão Plena de Atenção Básica e a Gestão Plena do Sistema Municipal de Saúde. A $11^{\text {a }}$ CNS deixou evidente a importância do controle social para que o Sistema Único fosse implementado nos mais de 5.500 municípios brasileiros. ${ }^{18}$

\section{A participação popular no SUS}

O ethos que permeia hoje o sistema brasileiro de saúde prevê a imprescindibilidade dos Conselhos de Saúde (CS). Estes são estruturas de atuação híbridas com o governo ${ }^{19}$, e devem ser o lócus onde se manifestam os interesses dos diferentes segmentos sociais, visando a possibilitar a negociação entre propostas que pretendem direcionar os recursos da saúde para objetivos diferentes. Os Conselhos de Saúde se organizam nas três esferas de governo: municipal, estadual e federal.

O ideal que sustenta os CS é o de que as formas mais eficazes de fiscalização e pressão são as de iniciativa preponderantemente de movimentos e entidades da sociedade civil organizada. Esta fiscalização se daria como resultante da articulação e da negociação dos interesses fracionados e específicos de cada segmento, em favor dos interesses e direitos de cidadania do conjunto da sociedade (MS, 2000).

Pode-se ler no parágrafo segundo do artigo primeiro da Lei 8.142/90 o seguinte: "O Conselho de Saúde, em caráter permanente e deliberativo, órgão colegiado composto por representantes do governo, prestadores de serviço, profissionais de saúde e usuários, atua na formulação de estratégias e no controle da execução da política de saúde na instância correspondente, inclusive nos aspectos econômicos

\footnotetext{
$1811^{\text {a }}$ Conferência Nacional de Saúde in Relatório Final "Efetivando o SUS: acesso, qualidade e humanização na atenção à saúde com controle social"

19 Legalmente, o Estado deve oferecer a infra-estrutura para o funcionamento dos Conselhos, como sala para reuniões, funcionários, telefone, etc. Além disto, o governo divide os assentos do Conselho com os movimentos sociais.
} 
e financeiros, cujas decisões serão homologadas pelo chefe do poder legalmente constituído em cada esfera do governo" (Legislação Federal, Lei no 8.142/90).

Desta perspectiva, as atribuições dos CG são: atuar na formulação e controle da execução da política de saúde, incluídos seus aspectos econômicos, financeiros e de gerência técnico-administrativa; traçar diretrizes de elaboração e aprovar os planos de saúde, adequando-os às diversas realidades epidemiológicas e à capacidade organizacional dos serviços; e estabelecer critérios e diretrizes quanto à localização e ao tipo de unidades prestadoras de serviços de saúde públicos e privados, no âmbito do SUS.

O trabalho destes Conselhos não deve ser confundido com o papel executivo do gestor de saúde. Este é o responsável pela execução da política de saúde, aquele por propor as diretrizes desta política, acompanhando as ações e fiscalizando a utilização dos recursos.

Em sua composição os CS devem contar com $50 \%$ de seu quadro de usuários do SUS e $25 \%$ dos quadros divididos entre governo e prestadores de serviços públicos e privados, restando, os demais $25 \%$ aos trabalhadores da saúde. Os usuários devem ser indicados por organismos ou entidades civis como movimentos comunitários, associações de moradores, de portadores de deficiência, de idosos, de defesa do consumidor ou eleitos na Conferência de Saúde.

Já os representantes do governo devem ser indicados pelos órgãos governamentais locais, como Prefeituras, ou pelos Estados e pela União. Os prestadores de serviços devem ser indicados por entidades que atuam no setor de assistência à saúde públicos e/ou privados. Já os trabalhadores da saúde devem ser profissionais da área administrativa ou de cuidados à saúde, e eleitos entre as entidades sindicais de saúde existentes nas diversas esferas do Estado (Prefeituras, governos estaduais e Federal). Membros do Legislativo não podem fazer parte dos CS. 
Estes Conselhos estão presentes na estrutura legal do Poder Executivo, sendo um mecanismo de fiscalização social dentro do Estado, ficando evidente tal presença ao olharmos os números oficiais em publicação do Ministério da Saúde: "hoje há mais de 50.000 Conselheiros de saúde nos 27 CS estaduais, há 3.000 CS municipais com funcionamento normal e regular (restam pouco mais de 1.900 Conselhos Municipais de Saúde com funcionamento ainda precário ou irregular)" (MS: 2000).

\section{Participação popular em saúde em São Paulo}

Em São Paulo, a organização do que se convencionou chamar de Movimento Popular de Saúde teve início principalmente em meados da década de 1970, em meio a um cenário de repressão política e cultural e de desigualdades sociais acentuadas.

Nesta época, na Zona Leste do município, intensificou-se a participação popular pela obtenção de serviços de saúde, serviços estes praticamente inexistentes naquela região. Em 1977, sanitaristas, estudantes, participantes das pastorais de saúde, dos clubes de mães, do movimento de custo de vida, e das associações de bairros, construíram as duas primeiras comissões de saúde da zona Leste: uma no Jd. Nordeste e outra em São Mateus.

Tais movimentos tiveram por conquista de suas reivindicações o Centro de Saúde do Jd. Nordeste, inaugurado em 1978. As modalidades de lutas destes movimentos eram assembléias populares, abaixo-assinados, passeatas e caravanas aos órgãos responsáveis pela saúde (Secretarias), no intuito de cobrar compromissos assumidos ou apresentar novas reivindicações.

Em 1979, uma assembléia em São Mateus, com mais de mil pessoas e com a presença do Secretário de Saúde, propôs a criação de um conselho de representantes da comunidade para fiscalizar os serviços de saúde. Isso foi somado à criação de um "conselho de notáveis do bairro" (delegados, presidentes 
de clubes de serviços, diretores de escolas e políticos) - instituído na mesma época, pela Secretaria Estadual de Saúde.

Imediatamente, a comissão de saúde da Zona Leste exigiu que os conselheiros usuários também fossem reconhecidos neste conselho, proposta aceita pelo governo do Estado, e, em dez dias, 8.146 pessoas haviam elegido 12 donas de casa para constituírem o $1^{\circ}$ Conselho de Saúde, o qual teria mandato por um prazo de dois anos (Sader, 1988 e Polis/PUC, 2002).

Em 1989, com o governo da então Prefeita Luiza Erundina (PT), o Secretário de Saúde, Eduardo Jorge, que foi militante do movimento de saúde da Zona Leste, auxiliou na criação do Conselho Municipal de Saúde.

Este tipo de política tornou-se usual em localidades governadas pelo Partido dos Trabalhadores, que tem por prática ocupar-se em estabelecer canais de interlocução com a sociedade. Este Conselho, contudo, foi extinto em 1993 com a chegada do Plano de Atendimento à Saúde (PAS), implantado no município pelo ex-Prefeito Paulo Maluf (Partido Progressista). ${ }^{20} \mathrm{O}$ Conselho do SUS foi retomado, em 2001, pelo, novamente Secretário de Saúde Eduardo Jorge.

Neste mesmo ano, foi aprovada na Câmara Municipal uma lei estabelecendo a existência dos Conselhos Distritais e de Unidades de Saúde, órgãos que tiveram seu desenho institucional feito similar ao do Conselho Municipal, ou seja, paritários entre os usuários do SUS e os técnicos que operam o sistema de saúde (gestores, prestadores de serviços e funcionalismo público).

Com a efetivação das Subprefeituras, em 2002, a lei foi emendada para que os Conselhos se adequassem à nova realidade distrital, e passaram, então, a Conselhos Gestores de Saúde das 31 Subprefeituras do município de São Paulo.

\footnotetext{
${ }^{20}$ Durante seu mandato, o Conselho Municipal foi substituído pelo Conselho do PAS, que tinha seus membros nomeados pelo Prefeito, e os Conselheiros eram remunerados para a tarefa. $O$ Conselho Municipal, mesmo tendo sua obrigatoriedade estabelecida pelo SUS, pode deixar de existir devido ao fato de o então prefeito ter aberto mão do repasse federal do PAB para 0 município de São Paulo.
} 


\section{1 - Os estudos sobre fóruns participativos}

Muito se fala e pesquisa sobre este incremento participacionista institucionalizado pela Constituição de 1988. Do ponto de vista empírico, a maioria dos estudos acerca destes espaços deliberativos preocupou-se com a eficiência de seus desenhos institucionais: para que estes fossem assertivos no tocante à inclusão de segmentos sociais outrora excluídos da arena de decisões políticas; sobre qual seja a função destes espaços deliberativos; como os potenciais participantes devem chegar a estes espaços; que assuntos devem apreciar; a freqüência de seus encontros; o empenho dos gestores e políticos com o projeto; entre outros aspectos operacionais (Fung, 2004).

A literatura que estuda participação e deliberação democráticas no Brasil faz uma avaliação generalista da situação, colocando estes instrumentos como ferramentas que propiciam maior visibilidade e transparências às ações estatais, colaborando para a erosão de uma sociedade de cultura estatista (Lavalle et all, 2004)

Também descreveram estas experiências como se constituindo em fóruns que estimularam e consolidaram a capacidade propositiva dos movimentos sociais e outros setores da sociedade civil.

Lembraram ainda, os estudos sobre participação, que estes mecanismos têm servido de canais de expressão, defesa e reivindicação de direitos das pessoas, especialmente daquelas outrora excluídas dos processos redistributivos no Brasil (Dagnino, 2002, pp 162-163).

\section{A questão do desenho institucional}

A literatura mais específica sobre CGS tem trabalhado em uma perspectiva mais prática, avaliando a expectativa inicial de que a institucionalização desses novos 
espaços de formulação, gestão, controle e avaliação de políticas públicas tivessem impacto efetivo na redefinição e formulação das políticas públicas, a partir da inclusão de um amplo espectro de cidadãos neste processo. Esta inclusão deveria favorecer a troca de informação e a transparência do processo político, ampliando, assim, as chances de que as políticas viessem a se tornar mais responsivas às necessidades da população, e que os serviços públicos fossem distribuídos de forma mais eqüitativa.

Diversos autores que avaliaram o desempenho desses novos fóruns participativos sugeriram, no entanto, que esses mecanismos têm contribuído de forma bastante modesta para a incorporação das demandas da sociedade civil nas políticas, bem como para ampliar o controle social sobre essas políticas. Segundo eles, a tradição autoritária do Estado brasileiro; a presença de uma cultura política autoritária que em muitos casos dificulta reconhecer e respeitar o outro como cidadão; a fragilidade da vida associativa e a própria resistência dos atores sociais e estatais em aceitarem participar desses fóruns, têm comprometido a efetiva participação social no processo de formulação e gestão das políticas. ${ }^{21}$

Neste cenário, a participação realimentaria as desigualdades - gerando um déficit de representatividade de atores desavantajados (cidadãos com baixa renda, baixos níveis de escolaridade e de acesso à informação, por exemplos), em relação a outros atores privados com mais recursos -, seja porque os mais pobres seguirão excluídos e carentes de recursos para articular suas demandas, seja porque os custos de participação seguirão sendo menores para os que têm mais recursos.

Neste sentido, há uma literatura que argumenta que os diferentes graus de influência dos atores participantes sobre processos decisórios estabelecem novas formas de particularismo societal, sendo que um dos riscos presentes na abertura desses canais de participação foi o controle de instâncias decisórias pelos grupos mais ativos e consolidados (Jacobi, 2004). Ademais, haveria uma tendência a um

\footnotetext{
${ }^{21}$ Carneiro, 2002; Schattan e Veríssimo, 2004.
} 
baixo grau de institucionalização dessas arenas e pouca articulação institucional entre os órgãos de decisão administrativa e os órgãos políticos, formados por políticos eleitos nos poderes Executivo e Legislativo.

Por outro lado, há um número expressivo de estudos sugerindo que esses fóruns podem, sob determinadas condições, além de ser inclusivos e incorporar os segmentos mais desfavorecidos da sociedade, desempenhar um papel relevante no processo de definição das políticas públicas.

Análises na área de democracia deliberativa, por exemplo, apontaram para o impacto dos processos de deliberação na democratização de políticas. ${ }^{22} \mathrm{~A}$ literatura sobre processos deliberativos já foi capaz de relacioná-los com a continuidade da participação, na medida em que se constatou que diferentes regras produzem diferentes resultados: elas encorajaram a mobilização e até mesmo interferiram diretamente nas estratégias a serem utilizadas.

Assim, os processos de deliberação conformaram as estratégias dos atores políticos e estabeleceram os parâmetros para os resultados políticos e de políticas públicas (Wampler, 2004, p 374), de maneira que as propensões não foram abstratas, mas se situaram num contexto específico de relações institucionais que alavancaram ou restringiram a oportunidade para a participação dos atores da sociedade civil, incluindo as daqueles atores que foram mais ativos e mais bem posicionados no campo das relações sociais (Lavalle et. al., 2004).

Neste sentido, há evidências favoráveis à expectativa de que os novos espaços participativos possam ser arenas públicas de representação para grupos sociais excluídos das instituições da arena política tradicional, uma vez que atores ricos e pobres da sociedade civil parecem igualmente propensos a participar destas arenas - cujo desenho favorece potencialmente o protagonismo de grupos sociais tradicionalmente sub-representados ou desfavorecidos -, contrariamente à literatura segundo a qual a participação política seria, em grande medida, afetada pela riqueza pessoal.

${ }^{22}$ Fung, 2004; Avritzer, 2000; Avritzer, 2002; Wampler e Avritzer, 2004. 
Também há estudos que apontaram para o fato de que haver empenho do gestor de políticas públicas e a existência pregressa de movimentos sociais organizados foram variáveis fundamentais para o desenvolvimento de espaços deliberativos, como os orçamentos participativos. Deste prisma, a sinergia gerada entre estes dois atores políticos (sociedade civil e gestores públicos) foi essencial para estes fóruns, uma vez que o ator político predispôs-se a compartilhar seu poder de gestão e disponibilizou a infra-estrutura para a efetivação do OP, e os atores políticos demandaram participação e se organizaram em torno da vontade de participar (Linhares, 2006).

\section{Instituições e cultura política}

Contudo, há uma outra perspectiva de análises possível para os processos participativos e deliberativos. Desta seara, pode-se avaliar e tentar compreender qual a influência que a participação e deliberação exercem sobre as pessoas e movimentos sociais que fazem parte destes processos.

O processo participativo mais estudado no Brasil, devido ao tempo de sua existência - mais de dez anos - foi o Orçamento Participativo de Porto Alegre. As conclusões dos estudos afirmam que mesmo onde movimentos corporativos e ações egoístas eram as regras, a prática da participação envolveu um processo de aprendizado através do qual algumas das contradições da democratização puderam ser superadas e a organização da sociedade civil aumentada.

Segundo os achados de Abers, em estudo sobre o OP Portoalegrense, a confiança das pessoas de que a participação Ihes pudesse trazer benefícios tangíveis teve um efeito mobilizador, e o efeito desta mobilização equilibrou desigualdades organizacionais entre os grupos participantes ao longo do tempo. 
Gradualmente, os participantes aprenderam as práticas da decisão coletiva ${ }^{23}$ e a negociar com a Prefeitura ${ }^{24}$.

Ademais, a dinâmica da definição de prioridades teria resultado em negociações capazes de possibilitar a ação coletiva: na medida em que as pessoas acumularam experiência no processo participativo perceberam que, sendo indefinido o número de interações, a melhor alternativa para que saíssem ganhando sempre (ao menos, na maior parte das vezes) era a cooperação. Também perceberam que a preocupação pelos interesses dos outros não necessariamente reduziria sua possibilidade de ganhos (Abers, 2001).

Ainda sobre o estudo do OP, um dos fatores essenciais para o sucesso da política foi o esforço e investimento por parte das autoridades políticas e órgãos públicos locais no processo, uma vez que a Prefeitura teve que mostrar claramente aos participantes porque a presença nas assembléias os beneficiaria e depois teve que cumprir suas promessas estritamente. Um outro fator estreitamente ligado a este, e crucial para fomentar a mobilização, é o que ela chama de "efeito demonstração". Este efeito foi assegurado pela certeza por parte dos participantes do processo de que suas reivindicações seriam aceitas, uma vez que o poder público demonstrou isto, ao realizar obras oriundas de reivindicações de edições anteriores do OP.

Segundo a autora, os fóruns de políticas públicas, em geral, não atraem participantes porque não fica claro para pessoas a relação dos primeiros com a vida cotidiana das últimas. Por isso, a identificação e a divulgação dos efeitos das políticas governamentais na vida das pessoas foi crucial para o sucesso da participação.

\footnotetext{
${ }^{23}$ Como, por exemplo, promover reuniões coerentes, aprender como debater e votar questões complexas, permitir a expressão de todos os participantes.

${ }_{24}$ Inclusive no sentido de obter informações sobre as ações do governo, a ponto de desmascarar tentativas de encobrir "sob jargão técnico" os motivos reais por trás da rejeição ou mudança das demandas votadas como prioritárias.
} 
Finalmente, há a importância do fator tempo, já que os processos participativos podem ter um longo período de maturação. Aliás, no caso do OP de Porto Alegre, quando a política ofereceu resultados, um número significativamente maior de participantes se mobilizou. E, se a própria mobilização inicial levou algum tempo, os complexos processos que propiciaram o desenvolvimento de atitudes cooperativas entre os participantes foram ainda mais demorados.

Para esta pesquisa, destacaram-se três fatores como sendo responsáveis pelo sucesso das atividades destes fóruns participativos ${ }^{25}$ : 1) o reconhecimento da legitimidade destes fóruns por parte da sociedade civil; 2) o compromisso das autoridades públicas com o projeto de participação; 3) seu desenho institucional, a exemplo da publicização dos CGS e da eficiência e disponibilidade da infraestrutura burocrática que os envolvem.

Assim, o fato de que, se por um lado, a existência de mecanismos formais de participação não pode assegurar per se a participação da totalidade da sociedade civil, por outro, esse quadro muda com a presença de: i) uma sociedade civil organizada, ii) de um contexto institucional que promova a mobilização, inclusão e participação dos atores, e iii) de autoridades políticas comprometidas com projetos de democracia participativa/deliberativa (Schmitter, 2001; Fung, 2004).

Como trato da relação entre instituições e cultura política - mais especificamente da relação entre a participação em determinados CGS e os valores e atitudes políticos de seus conselheiros - devo reforçar como compreendo o termo neste trabalho. Para mim, uma instituição é fundamentada por condições formais de coordenação: dinheiro, autoridade e conhecimento. Mas, também é permeada por condições informais: os comprometimentos que resultam de imagens e crenças acerca da vida, bem como as ações que seguem a estas crenças, as quais membros das sociedades modernas compartilham sobre membros de outras comunidades. (Offe, 2001).

${ }^{25}$ Tendo sido este sucesso apontado pelos indicadores de melhor redistribuição de serviços públicos e/ou pela inclusão de atores políticos outrora excluídos, seja ainda notado pela mudança na cultura política dos atores envolvidos. 


\section{A pesquisa}

Uma vez que os Conselhos Gestores de Saúde, para além de estatutos legais e modos formais de ação coletiva, implicam em percepções sociais entre indivíduos racionais, faz-se importante discutir a relação entre ambos, ou seja, as influências recíprocas entre um ethos que coordena informalmente as pessoas quando estas se unem visando a sanar suas necessidades, e as regras formais que organizam estes espaços.

Pode-se perguntar: há alguma relação entre as diferentes formas de organização e funcionamento dos Conselhos Gestores de Saúde (seus modos formais de coordenação) e as orientações e práticas políticas de seus Conselheiros (seus modos informais de coordenação)?

Para se estudar esta questão, elaborei uma pesquisa experimental com 16 conselheiros, distribuídos em quatro Conselhos.

Para tanto, partiu-se de uma análise empírica das configurações concretas dos Conselhos, considerando: a) seus processos de organização como os métodos utilizados para que se compusesse sua infra-estrutura social; seus meios de divulgação e relacionamentos mantidos com outras organizações, associações e movimentos sociais que os integram; os arranjos jurídicos e políticos que norteiam seu processo de deliberação; e o empenho do gestor local com o sucesso do fórum.

Esta análise do desenho institucional destes fóruns serviu para que se pudesse selecionar os Conselhos nos quais seriam entrevistados os conselheiros. Preocupou-se, nesta seleção, em eleger quatro Conselhos com características institucionais diferentes, para que se pudesse avaliar a relação destes com o perfil das práticas e valores políticos dos conselheiros que deles fazem parte.

O passo seguinte foi avaliar o perfil de orientações políticas dos Conselheiros do segmento dos usuários do SUS que fazem parte dos Conselhos selecionados. 
Visando a esta finalidade, elaborou-se um questionário que foi aplicado a 16 conselheiros, nos quatro Conselhos diferentes. Este instrumento foi capaz de medir: i) a relação do conselheiro com seu entorno de moradia; ii) seu grau de associativismo e participação popular; iii) seus valores políticos e sociais; e iv) suas percepções acerca do sistema público de saúde.

Ao se propor este estudo experimental, verifico se há relação entre o desenho institucional dos Conselhos e os valores, atitudes e práticas políticas dos conselheiros. Desta forma, a hipótese que desta questão decorre é a seguinte: os valores, práticas e percepções políticas dos conselheiros variam de acordo com o desenho institucional dos Conselhos de Saúde.

Ao longo do trabalho, e se tendo percebido a variação da cultura política dos conselheiros em função do período de início de suas atividades associativas, verificou-se a hipótese complementar: os valores, percepções e atitudes políticas dos conselheiros variam de acordo com seu período de tempo de participação.

Tenho ciência das limitações desta proposta, uma vez que ideal seria se se pudesse experimentar a variação dos valores democráticos e práticas políticas dos conselheiros em relação a seu tempo de participação nos diversos Conselhos de Saúde. Contudo, o curto tempo de existência destes fóruns (apenas 05 anos), e o tempo destinado a esta pesquisa (02 anos) impedem que se faça um estudo longitudinal mais acurado. No entanto, este trabalho, que é uma pesquisa experimental, apresenta-se como uma primeira investigação, e deixa aberta a possibilidade de se retornar a estes mesmos conselheiros, com o passar do tempo, e se averiguar as variações de suas percepções, valores e práticas democráticas. 


\section{Capítulo III - Métodos de análise, escolha de casos e apresentação dos dados.}

Neste trabalho, o desenho institucional dos Conselhos (seus modos formais de coordenação) corresponde à variável independente; e a cultura cívica e o capital social (seus modos informais de coordenação), à variável dependente.

Para que se pudesse analisar a relação entre ambas, foram selecionados os Conselhos com base em dados de seu desenho institucional, como seus processos burocráticos, suas estratégias de publicização, e o empenho do gestor local de saúde com o funcionamento do fórum.

\section{Os Conselhos selecionados}

Parte dos dados que utilizei para a seleção dos Conselhos estudados têm sua fonte em um banco de dados gerado no início de 2004, em pesquisa realizada no Centro Brasileiro de Análise e Planejamento (CEBRAP). O problema da pesquisa que os originou foi a questão da existência de relações sistemáticas entre o grau de organização e comprometimento dos atores sociais e estatais, e a forma de organizar os Conselhos (Coelho, 2004, $p$ 257). ${ }^{26}$

O instrumento que colheu estes dados era destinado a avaliar o modus operandi destas instituições no que tangia a suas estruturas legal, administrativa, burocrática e de comunicação.

O questionário estava dividido em três blocos. O primeiro, intitulado eleições $e$ composição, visava a avaliar a formatação dos Conselhos Gestores de Saúde, como suporte governamental, paridade, regularidade das reuniões, e o respeito e operacionalização das leis que instituíram estes organismos ${ }^{27}$. O segundo bloco,

\footnotetext{
${ }^{26}$ A pesquisa intitula-se "Construindo Conselhos que façam a diferença", de uma parceria entre o Institute of Development Studies e o CEBRAP, sob a coordenação de Vera Schattan.

${ }^{27}$ Lei $n^{\circ} 13.325 / 02$ e Lei, $n^{\circ} 42.005 / 02$
} 
intitulado procedimentos, analisou a organização cotidiana destes Conselhos, como organização da Secretaria Geral, coordenação das reuniões, composição do Pleno e atribuição das Comissões e/ou grupos de trabalho, bem como meios burocráticos dos quais se utilizam os Conselhos de Saúde no seu dia-a-dia. No bloco relações, investigaram-se as diversas conexões mantidas pelos Conselhos com: demais CGS; outros Conselhos existentes (pessoa deficiente, educação, etc.); diversos movimentos sociais; e poderes Legislativo, Executivo e Judiciário.

Outra parte dos dados utilizados para a seleção dos Conselhos estudados teve sua fonte nos próprios Conselhos. Utilizei-me das listas de composição dos CGS para verificar a ocupação destes fóruns. Os Conselhos têm 24 assentos destinados à sociedade civil. Parte-se do suposto de que a plena ocupação destas cadeiras demonstra a legitimação destes espaços por parte da sociedade civil. Os números podem indicar, ainda, uma maior ou menor eficiência do governo local na publicização dos processos de eleição dos conselheiros para os Conselhos.

Utilizando-me destes dados (do CEBRAP e dos Conselhos), elaborei um indicador sintético intitulado Índice de Institucionalidade. ${ }^{28} \mathrm{O}$ propósito deste índice foi o de verificar maior ou menor fluidez e assertividade nos processos deliberativos dos Conselhos; apurar a facilitação das operações cotidianas do Conselho via atitudes de fomento tomadas pelo gestor de saúde local; e checar se os Conselhos mais bem divulgados demonstraram ter uma ocupação maior de representantes civis em seus assentos.

A variação deste índice, como as de todos os demais, apresentou-se de zero $(0,00)$ a um $(1,00)$. Esta oscilação significa que quanto mais próximo a 1,00 mais institucionalizado demonstrou-se o Conselho. Para obter-se este intervalo, utilizeime de um cálculo aritmético dos dados obtidos para os CGS, o qual: (valor observado - menor valor do conjunto) / (Maior valor do conjunto - menor valor do conjunto), ou (VO-mvc) / (Mvc-mvc).

\footnotetext{
${ }^{28}$ A descrição da metodologia para confecção destes indicadores está detalhada no apêndice "b" deste trabalho.
} 
O índice de Institucionalidade está apresentado na tabela abaixo: ${ }^{29}$

TABELA 01 - APRESENTAÇÃO DO ÍNDICE DE INSTITUCIONALIDADE PARA AS 31 SUBPREFEITURAS DE SÃO PAULO, 2005.

\begin{tabular}{|l|r|}
\hline \multicolumn{2}{|c|}{ INDICE DE INSTITUCIONALIDADE } \\
\hline Conselho & Inst \\
\hline Aricanduva & 0,87 \\
\hline Butantã & 0,69 \\
\hline Campo Limpo & 0,56 \\
\hline Casa Verde & 0,56 \\
\hline Cidade Ademar & 0,97 \\
\hline Cidade Tiradentes & 0,61 \\
\hline Ermelino Matarazzo & 0,61 \\
\hline Freguesia do O & 0,68 \\
\hline Guaianazes & 0,61 \\
\hline Ipiranga & 0,00 \\
\hline Itaim Paulista & 0,62 \\
\hline Itaquera & 0,38 \\
\hline Jabaquara & 0,69 \\
\hline Jd Ângela & 0,15 \\
\hline Lapa & 0,72 \\
\hline Mooca & 0,53 \\
\hline Parelheiros & 0,84 \\
\hline Penha & 0,66 \\
\hline Perus & 0,70 \\
\hline Pinheiros & 0,82 \\
\hline Pirituba & 0,76 \\
\hline Santana & 1,00 \\
\hline Santo Amaro & 0,55 \\
\hline São Mateus & 0,51 \\
\hline São Miguel & 0,83 \\
\hline Se & 0,75 \\
\hline Socorro & 0,76 \\
\hline Tremembé & 0,67 \\
\hline VI Maria & 0,79 \\
\hline VI Mariana & 0,96 \\
\hline VI Prudente/Sapopemba & 0,42 \\
\hline FONTE: Banco de dados CEBRAPIIDS. 2004; CGS, $2004 / 05$ \\
\hline
\end{tabular}

${ }^{29} \mathrm{Em}$ todas as tabelas coloridas foi adotada a convenção de cores de que a mediana aparece em azul, os valores abaixo dela em vermelho, e os acima em verde. 
Percebe-se ao analisar os dados que o Conselho da Subprefeitura de Tremembé foi o que qualificou a mediana $(0,67)$, o de Ipiranga apresentou o menor indicador $(0,00)$ e Santana o maior $(1,0)$.

Para aproximar os Conselhos no que tange às realidades socioeconômicas das Subprefeituras nas quais estão localizados, utilizei o Índice de Desenvolvimento Humano - Municipal (IDH-M) como parâmetro. Esta aproximação é importante para se evitar que a observação de uma possível variação no perfil de comportamento político dos conselheiros se desse por fatores socioeconômicos locais, e não devido à variação do desenho institucional dos Conselhos.

Este índice - elaborado levando-se em conta a metodologia internacional de cálculo para o IDH desenvolvida por Amartya Sen -, tem por objetivo a incorporação da dimensão humana ao planejamento do desenvolvimento, visando-se a especificar não apenas o que está sendo produzido, mas como o que se espera da distribuição deste produto, bem como permite que se planeje que tipo de políticas concretas devem ser aplicadas para assegurar uma eqüitativa distribuição de renda (Pedroso, 2003).

Para este estudo, foram selecionados quatro Conselhos entre os 31 que compõem o universo do município de São Paulo (01 CGS em cada Subprefeitura). A questão que se coloca é: tudo o mais constante no quesito socioeconômico, se o fato de um Conselho ter se apresentado mais ou menos institucionalizado apresentou correlação com as atitudes e valores políticos de seus Conselheiros.

Para tanto, escolheram-se dois Conselhos com colocações no Índice de Institucionalidade acima da mediana, e dois com colocações abaixo. A seguir está apresentada a forma da seleção: 
TABELA 03 - DEMONSTRAÇÃO DA METODOLOGIA PARA SELEÇÃO DOS CONSELHOS ESTUDADOS, 2005.

\begin{tabular}{|c|c|c|}
\hline \multicolumn{3}{|c|}{ CONSELHOS SELECIONADOS } \\
\hline CONSELHOS & IDH-M & Ilnst \\
\hline A & constante & acima da mediana \\
\hline B & constante & acima da mediana \\
\hline C & constante & abaixo da mediana \\
\hline D & constante & abaixo da mediana \\
\hline
\end{tabular}

Para visualizar os Conselhos selecionados (grifado em cinza), apresento a tabela abaixo: 
TABELA 04 - APRESENTAÇÃO DOS CONSELHOS SELECIONADOS, 2005.

\begin{tabular}{|l|c|c|}
\hline \multicolumn{3}{|c|}{ CONSELHOS SELECIONADOS } \\
\hline \multicolumn{1}{|c|}{ Subprefeitura/Conselho } & IDH-M & IInst \\
\hline Aricanduva & 0,763 & 0,87 \\
\hline Butantã & 0,79 & 0,69 \\
\hline Campo Limpo & 0,74 & 0,56 \\
\hline Casa Verde & 0,73 & 0,56 \\
\hline Cidade Ademar & 0,695 & 0,97 \\
\hline Cidade Tiradentes & 0,672 & 0,61 \\
\hline Ermelino & 0,732 & 0,61 \\
\hline Freguesia do O & 0,7 & 0,68 \\
\hline Guaianazes & 0,674 & 0,61 \\
\hline Ipiranga & 0,767 & 0 \\
\hline Itaim Paulista & 0,671 & 0,62 \\
\hline Itaquera & 0,71 & 0,38 \\
\hline Jabaquara & 0,733 & 0,69 \\
\hline Jd Ângela & 0,644 & 0,15 \\
\hline Lapa & 0,853 & 0,72 \\
\hline Mooca & 0,8 & 0,53 \\
\hline Parelheiros & 0,65 & 0,84 \\
\hline Penha & 0,735 & 0,66 \\
\hline Perus & 0,698 & 0,70 \\
\hline Pinheiros & 0,91 & 0,82 \\
\hline Pirituba & 0,711 & 0,76 \\
\hline Santana & 0,81 & 1 \\
\hline Santo Amaro & 0,856 & 0,55 \\
\hline São Mateus & 0,676 & 0,51 \\
\hline São Miguel & 0,677 & 0,83 \\
\hline Se & 0,842 & 0,75 \\
\hline Socorro & 0,671 & 0,76 \\
\hline Tremembé & 0,68 & 0,67 \\
\hline VI Maria & 0,735 & 0,79 \\
\hline VI Mariana & 0,88 & 0,96 \\
\hline VI Prudente/Sapopemba & 0,699 & 0,42 \\
\hline FONTE: Banco de dados CEBRAPIDS. 2004; PMSP/CGS $2004 / 05 ;$ e Pedroso, \\
\hline 2001. & & \\
\hline
\end{tabular}

Todos os Conselhos tiveram suas variações socioeconômicas aproximadas pelo IDH-M: Parelheiros 0,650; Cidade Tiradentes 0,672; Perus 0,698 e Vila Prudente/Sapopemba 0,699. Assim, Perus e Parelheiros foram os Conselhos que 
apresentaram o Índice de Institucionalidade acima da mediana $(0,70$ e 0,84 respectivamente). Em oposição, Cidade Tiradentes e Vila Prudente apresentaram este indicador abaixo da mediana $(0,61$ e 0,42$)$.

Para a seleção dos conselheiros estudados levaram-se em consideração informações que demonstraram a intensidade de suas atividades participativas ao longo de sua vida.

\section{Os conselheiros selecionados}

Para esta seleção, utilizei-me da quantificação do número de instituições de cunho participativo das quais os conselheiros fizeram parte.

Tal quantificação foi utilizada para se averiguar se as atitudes e valores políticos dos conselheiros em questão foram fruto de um processo de construção pregresso a seu ingresso no Conselho. Assim, esta variável, além de selecionar os conselheiros, colocou-se como variável de controle neste trabalho.

Para se levantar estes dados, foi aplicado para todos os conselheiros titulares do segmento dos usuários do SUS dos 04 CGS selecionados (34 pessoas) ${ }^{30}$ um breve questionário colhendo dados acerca de seu envolvimento com instituições de cunho participativo ao longo de suas vidas.

Ao analisar os dados obtidos, percebeu-se que há clara distinção entre três períodos de início de participação entre os conselheiros. Estes períodos diferem pelo fato de suas atividades terem seu início em datas diferentes no tempo. $O$ período de participação "depois de 2001" teve por característica ser um tipo de participação que se inicia com o forte incremento da Prefeitura de São Paulo na

\footnotetext{
${ }^{30}$ São 34 , e não 48 , os conselheiros entrevistados devido ao fato de que 14 deles não foram encontrados, todos devido a motivos de força maior (por terem mudado de domicílio, por terem perdido o telefone, ou não quererem dar entrevistas).
} 
criação de políticas públicas como o Orçamento Participativo e os Conselhos Gestores de Políticas Públicas.

Os dois outros períodos ("anterior e/ou 1980" e "entre 1981 e 1992") tiveram por característica iniciarem-se antes mesmo da década de 1980, e apresentarem maior freqüência entre os anos 1981 e 1992, franco processo de abertura e consolidação democráticas no Brasil.

Vale lembrar que os períodos em questão possuem suas matizes próprias: o período "anterior e/ou até 1980" foi marcado pelo fortalecimento eleitoral do MDB, em 1974, e pelas greves operárias de 1978. Esta segunda metade da década de 1970 foi apresentada pela literatura da época como sendo o período no qual os movimentos sociais e operários emergiram com a marca da autonomia e da contestação à ordem estabelecida (Sader, 1988, p 35).

O segundo período, "entre 1981 e 1992" foi de grande efervescência social e conquistas democráticas. Obtém-se a anistia partidária no governo Figueiredo, o que abriu a possibilidade de eleição direta para governadores e parlamentares. Elegeu-se o primeiro Presidente civil após cerca de vinte anos de ditadura (1985); promulga-se a Constituição Cidadã (1988); impediu-se o exercício de um Presidente democraticamente eleito através de manifestações populares e ações do Congresso Nacional (1992).

Já o terceiro período, "depois de 2001", amadureceu a tendência que se observava ao final da década de 1990 de início da relação entre sociedade civil e Estado. Nesta etapa as associações iniciam um relacionamento com os partidos políticos por um lado, e com as agências públicas por outro. Neste ponto surgem os conselhos de políticas públicas no Brasil, das mais diversas ordens, do negro à mulher, passando pela saúde e criança. Esta participação em conselhos populares evoluiu para sua forma institucional, num híbrido entre sociedade civil e Estado. Esta institucionalização colocava em questão o discurso dos movimentos nos dois períodos anteriores, pois a identidade dos movimentos estava calcada no discurso da espontaneidade e parecia difícil encontrar caminho para a co-participação no 
Estado. Contudo, o privado estava entrando no público, gerando tensões e controvérsias acerca do modus operandi de como os movimentos se apoderariam deste novo cenário, ou seja, quem teria direito a participar, de que maneira, em que momento, e uma sorte de um sem número destas questões operacionais (Cardoso, 1994).

Os dados dos distintos períodos de participação podem ser vistos na tabela abaixo:

TABELA 05 - FREQUÊNCIA DO ANO DE INÍCIO DE PARTICIPAÇÃO DOS CONSELHEIROS, 2005.

\begin{tabular}{|l|c|c|}
\hline \multicolumn{2}{|c|}{ período de tempo de participação } \\
\hline \multicolumn{1}{|c|}{ ano de início } & $\mathbf{N}$ & $\%$ \\
\hline até 1980 & 5 & 31,3 \\
\hline entre 1981 e 1992 & 6 & 37,5 \\
\hline depois de 2001 & 5 & 31,3 \\
\hline Total & 16 & 100 \\
\hline
\end{tabular}

FONTE: VERISSIMO, 2005.

Esta informação é de fundamental importância, uma vez que permitiu que se controlasse a variável dependente (os valores, percepções e orientações políticas dos conselheiros) por grupos de ano de início de participação dos conselheiros. Isto permitiu uma hipótese complementar a este trabalho: os valores, percepções e atitudes políticas dos conselheiros variam de acordo com seu período de tempo de participação.

Assim, a seleção de conselheiros levou em conta os dados da seguinte maneira: foram escolhidos quatro conselheiros em cada um dos quatro Conselhos, dois conselheiros acima da mediana do número de instituições das quais participou desde o início de suas atividades associativas, e dois abaixo, totalizando uma amostra de 16 indivíduos.

Abaixo podemos ver a tabela com todos os conselheiros selecionados lado a lado: 
TABELA 06 - APRESENTAÇÃO DOS CONSELHEIROS SELECIONADOS, POR CONSELHO, 2005.

\begin{tabular}{|c|c|c|c|c|c|c|}
\hline \multicolumn{7}{|c|}{ Conselheiros Selecionados - Índice de Participação } \\
\hline \multirow[b]{2}{*}{ Conselho } & \multirow[b]{2}{*}{ Conselheiro } & \multicolumn{3}{|c|}{$\begin{array}{c}\text { Período de Participação (N de } \\
\text { associações) }\end{array}$} & \multirow[b]{2}{*}{ total } & \multirow[b]{2}{*}{ IP } \\
\hline & & $\begin{array}{c}\text { período } \\
\text { anterior } \\
\text { e/ou até } \\
1980\end{array}$ & $\begin{array}{c}\text { entre } \\
1981 \\
\text { até } \\
1992 \\
\end{array}$ & $\begin{array}{l}\text { depois } \\
\text { de } 2001\end{array}$ & & \\
\hline \multirow{4}{*}{ Parelheiros } & P5 & 0 & 1 & 1 & 2 & 0,00 \\
\hline & P8 & 1 & 0 & 1 & 2 & 0,00 \\
\hline & P9 & 0 & 0 & 5 & 5 & 1,00 \\
\hline & P12 & 0 & 4 & 1 & 5 & 1,00 \\
\hline \multirow{4}{*}{ VI Prudente } & VP1 & 2 & 2 & 3 & 7 & 0,86 \\
\hline & VP3 & 0 & 0 & 1 & 1 & 0,00 \\
\hline & VP9 & 0 & 0 & 1 & 1 & 0,00 \\
\hline & VP12 & 0 & 1 & 4 & 5 & 0,57 \\
\hline \multirow{4}{*}{ Cid Tiradentes } & CT1 & 0 & 0 & 2 & 2 & 0,00 \\
\hline & CT7 & 0 & 1 & 1 & 2 & 0,00 \\
\hline & CT8 & 2 & 1 & 4 & 7 & 0,63 \\
\hline & СТ9 & 0 & 5 & 5 & 10 & 1,00 \\
\hline \multirow{4}{*}{ Perus } & $\mathrm{Pe} 2$ & 0 & 0 & 2 & 2 & 0,00 \\
\hline & $\mathrm{Pe} 3$ & 0 & 1 & 2 & 3 & 0,25 \\
\hline & Pe10 & 2 & 2 & 2 & 6 & 1,00 \\
\hline & $\mathrm{Pe} 12$ & 1 & 1 & 3 & 5 & 0,75 \\
\hline
\end{tabular}

FONTE: VERÍSSIMO, J. 2005.

Nesta tabela constam os Conselhos selecionados, na primeira coluna. $\mathrm{Na}$ segunda apresento os conselheiros elencados. Para preservá-los da exposição de seus nomes, Ihes atribuí siglas: as letras remetem-se aos Conselhos dos quais são oriundos, e os números correspondem à sua posição inicial no conjunto de conselheiros de seu Conselho de origem (estes conjuntos variam de 01 a 12, e podem ser vistos no apêndice "a" deste trabalho).

A coluna de período de participação indica a quantidade de instituições das quais o conselheiro fez parte a partir do período de tempo de início de sua participação. A última coluna, intitulada Índice de Participação $(I P)$, apresenta a variação dos 
conselheiros de zero $(0,00)$ a um $(1,00)$. Quanto mais próximo de 1,00 mais participação. ${ }^{31}$

Assim, percebe-se na tabela 06 que os conselheiros selecionados tiveram perfis diversos em relação à sua participação. Em Vila Prudente, por exemplo, vê-se os conselheiros VP3 e VP9 apresentaram os mais baixos indicadores de participação do conjunto $(0,00)$, o que também ocorreu com os conselheiros P5, P8, CT1, CT7 e Pe2.

Contudo, há casos como o de CT9, em Cidade Tiradentes, que apresentou participar desde a década de 1980 em cinco associações, e depois de 2001 iniciou a participação em outras cinco. Seu indicador foi o maior possível: 1,00. também apresentaram este indicador os conselheiros P9, P12 e Pe10.

Já em Perus, Pe2 iniciou sua participação depois de 2001 participando em 02 associações, e seu indicador ficou em 0,00. Neste Conselho Pe12 disse participar em uma associação desde o período anterior e/ou até 1980, e em uma "entre 1981 e 1992", e iniciou a participar em outras três depois de 2001, de maneira que seu índice ficou em 0,75.

Apresentada a metodologia para seleção dos casos estudados, passo agora à exposição do questionário utilizado para se medir as percepções e práticas políticas dos conselheiros.

\section{O questionário aplicado aos conselheiros}

Selecionados os conselheiros, a etapa seguinte foi a de entrevistá-los. Para tanto, foi elaborado um questionário e, a partir de seus resultados, confeccionaram-se indicadores objetivos que permitiram a análise das variações de suas respostas no

\footnotetext{
${ }^{31}$ Para cálculo deste índice utilizei-me da mesma fórmula que os demais índices deste trablho. Dada a soma da quantidade de instituições das quais os conselheiros fizeram parte, utilizei-me do cálculo (VOC$\mathrm{mVC}) /($ Mvc-mvc).
} 
tocante a seus graus de: informação geral e política, valores sócio-políticos, participação e associativismo, capital social, tolerância, capilaridade social, confiança generalizada, na polícia e no sistema médico, e percepções acerca do sistema público de saúde e do papel institucional dos Conselhos.

O questionário foi elaborado contendo seis blocos (avaliação do entorno de moradia; avaliação do capital social e participação; avaliação da participação política e associativismo; avaliação de valores políticos; avaliação das percepções do conselheiro sobre o sistema público de saúde; e avaliação socioeconômica). ${ }^{32}$

Utilizei-me de três metodologias diferentes neste instrumento de coleta. A primeira delas consistiu em perguntas de opinião fechadas e auto-posicionamentos em escalas. No último bloco do questionário foi utilizado um método que consistiu em contar pequenas estórias para os conselheiros (que tinham por teor situações vividas no cotidiano dos Conselhos), e convidá-los a posicionarem-se em uma escala de zero a 10 , dadas as assertivas apresentadas em relação às estórias. 0 último método foi uma pergunta aberta, questionando-os acerca de suas motivações primeiras para terem se envolvido com participação popular, bem como qual foi sua trajetória associativa e profissional.

\footnotetext{
${ }^{32} \mathrm{~A}$ íntegra do questionário pode ser vista no anexo deste trabalho.
} 


\section{1 - Apresentação dos resultados}

Apresento agora os resultados da pesquisa. ${ }^{33}$ As tabelas são apresentadas da seguinte maneira: os números constantes nas células indicam a quantidade de conselheiros que respondeu às questões de maneira afirmativa $(\mathrm{N})$. Os totais foram calculados por coluna e linha, indicando a somatória das respostas por categoria (Conselhos ou Grupos de período de início de participação) e pelo total da amostra.

\section{a) Informação Geral}

Como se vê nas tabelas abaixo, a TV e o rádio foram os dois veículos de informação mais utilizados pelos conselheiros tanto agrupados por Conselho, quanto agregados por período de início de participação. Este dado foi fortalecido pelas tabelas que se seguem. Perguntados acerca da freqüência com que utilizaram os meios de comunicação, a TV apareceu como veículo sempre utilizado pelos conselheiros, quando agregados por Conselhos. Já quando agregados por período de início de participação, a importância da televisão foi compartilhada, nos grupos "até 1980" e "entre 1981 e 1992", com a leitura de jornais e com a conversa sobre política com os amigos. No grupo "depois de 2001", a TV voltou a ter preponderância praticamente absoluta como fonte de informação política dos conselheiros.

\footnotetext{
${ }^{33}$ Vale lembrar, como disse no final do capítulo 02, que esta é uma pesquisa experimental, não estatística, e que tem por finalidade a exploração de evidências acerca da relação entre instituições e cultura cívica, bem como entre esta e o período de início de participação dos conselheiros.
} 
TABELA 07: FREQUÊNCIA DE USO DE FONTES DE INFORMAÇÃO GERAL UTILIZADAS PELOS CONSELHEIROS, POR CONSELHO DE QUE FAZ PARTE.

\begin{tabular}{|c|c|c|c|c|c|c|}
\hline \multicolumn{7}{|c|}{$\begin{array}{l}\text { Agora eu gostaria de saber sobre o uso que você faz de meios de } \\
\text { comunicação como jornal, rádio e televisão. Com que freqüência você * }\end{array}$} \\
\hline $\begin{array}{c}\text { Conselho } \\
\text { de que faz } \\
\text { parte }\end{array}$ & Veículo & $\begin{array}{l}\text { diariamente/quase } \\
\text { todos dias }\end{array}$ & $\begin{array}{c}\text { algumas } \\
\text { vezes por } \\
\text { semana }\end{array}$ & $\begin{array}{l}\text { quase } \\
\text { nunca }\end{array}$ & $\begin{array}{c}\text { não } \\
\text { tem o } \\
\text { hábito }\end{array}$ & Total \\
\hline \multirow{3}{*}{$\begin{array}{l}\mathrm{VI} \\
\text { Prudente }\end{array}$} & TV & 4 & & & & 4 \\
\hline & Rádio & 3 & 1 & & & 4 \\
\hline & Jornal & 0 & 3 & & 1 & 4 \\
\hline \multicolumn{2}{|l|}{ Total } & 7 & 4 & & 1 & 12 \\
\hline \multirow{3}{*}{ Perus } & TV & 3 & & 1 & & 4 \\
\hline & Rádio & 3 & 1 & & & 4 \\
\hline & Jornal & 4 & & & & 4 \\
\hline \multicolumn{2}{|l|}{ Total } & 10 & 1 & 1 & & 12 \\
\hline \multirow{3}{*}{$\begin{array}{l}\text { Cid } \\
\text { Tiradentes }\end{array}$} & TV & 4 & & & & 4 \\
\hline & Rádio & 3 & 1 & & & 4 \\
\hline & Jornal & 1 & 1 & 2 & & 4 \\
\hline \multicolumn{2}{|l|}{ Total } & 8 & 2 & 2 & & 12 \\
\hline \multirow{3}{*}{ Parelheiros } & TV & 4 & & & & 4 \\
\hline & Rádio & 1 & & 1 & 2 & 4 \\
\hline & Jornal & 0 & 2 & 2 & & 4 \\
\hline \multicolumn{2}{|l|}{ Total } & 5 & 2 & 3 & 2 & 12 \\
\hline
\end{tabular}

FONTE: VERÍSSIMO, J. 2005.

* Respostas múltiplas 
TABELA 7.1: FREQUÊNCIA DE USO DE FONTES DE INFORMAÇÃO GERAL UTILIZADAS PELOS CONSELHEIROS, POR PERÍODO DE INÍCIO DE PARTICIPAÇÃO.

\begin{tabular}{|c|c|c|c|c|c|c|}
\hline \multicolumn{7}{|c|}{$\begin{array}{c}\text { Agora eu gostaria de saber sobre o uso que você faz de meios de comunicação } \\
\text { como jornal, rádio e televisão. Com que freqüência vocêt }\end{array}$} \\
\hline Período & Veículo & $\begin{array}{l}\text { diariamente/quase } \\
\text { todos dias }\end{array}$ & $\begin{array}{l}\text { algumas vezes } \\
\text { por semana }\end{array}$ & $\begin{array}{l}\text { quase } \\
\text { nunca }\end{array}$ & $\begin{array}{l}\text { não tem } \\
\text { o hábito }\end{array}$ & Total \\
\hline \multirow{4}{*}{ 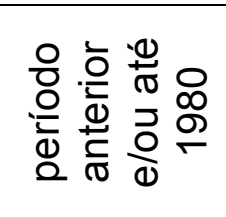 } & TV & 5 & & & & 5 \\
\hline & Rádio & 2 & 1 & & 2 & 5 \\
\hline & Jornal & 1 & 2 & 2 & & 5 \\
\hline & Total & 8 & 3 & 2 & 2 & 15 \\
\hline \multirow{4}{*}{ 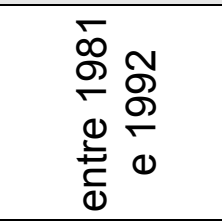 } & TV & 5 & & 1 & & 6 \\
\hline & Rádio & 4 & 1 & 1 & & 6 \\
\hline & Jornal & 2 & 2 & 2 & & 6 \\
\hline & Total & 11 & 3 & 4 & & 18 \\
\hline & & & & & & \\
\hline \multirow{4}{*}{$\begin{array}{l}\frac{0}{0} \\
\frac{\infty}{0} \overline{8} \\
\frac{0}{0}\end{array}$} & TV & 5 & & & & 5 \\
\hline & Rádio & 4 & 1 & & & 5 \\
\hline & Jornal & 2 & 2 & & 1 & 5 \\
\hline & Total & 11 & 3 & & 1 & 15 \\
\hline
\end{tabular}

FONTE: VERISSSIMO, J. 2005.

${ }^{*}$ Respostas múltiplas

O uso da internet, como apresentado nas tabelas abaixo, demonstrou-se muito escasso entre os conselheiros. 11 dos 16 entrevistados afirmaram não fazer uso da rede de computadores, e não há variação neste dado quando analisado por período de início da participação. 
TABELA 08: USO DA INTERNET PELOS CONSELHEIROS, POR CONSELHO DE QUE FAZ PARTE.

\begin{tabular}{|l|c|c|c|}
\hline \multicolumn{3}{|c|}{$\begin{array}{c}\text { Apesar de sabermos que o uso da Internet } \\
\text { ainda é pequeno, gostaríamos de Ihe } \\
\text { perguntar se você já usa a Internet? }\end{array}$} \\
\hline $\begin{array}{l}\text { Conselho de que faz } \\
\text { parte }\end{array}$ & sim & não & Total \\
\hline VI. Prudente & 1 & 3 & 4 \\
\hline Perus & 2 & 2 & 4 \\
\hline Cid. Tiradentes & 1 & 3 & 4 \\
\hline Parelheiros & 1 & 3 & 4 \\
\hline Total & 5 & 11 & 16 \\
\hline
\end{tabular}

FONTE: VERISSSIMO, J. 2005.

\section{TABELA 8.1: USO DA INTERNET PELOS CONSELHEIROS, POR PERÍODO DE INÍCIO DE PARTICIPAÇÃO.}

\begin{tabular}{|l|c|c|c|}
\hline \multicolumn{4}{|c|}{$\begin{array}{c}\text { Apesar de sabermos que o uso da Internet } \\
\text { ainda é pequeno, gostaríamos de Ihe } \\
\text { perguntar se você já usa a Internet? }\end{array}$} \\
\hline $\begin{array}{l}\text { Período } \\
\text { sim }\end{array}$ & não & Total \\
\hline $\begin{array}{l}\text { período anterior e/ou até } \\
1980\end{array}$ & 0 & 5 & 5 \\
\hline entre 1981-1992 & 4 & 2 & 6 \\
\hline depois de 2001 & 1 & 4 & 5 \\
\hline Total & 5 & 11 & 16 \\
\hline
\end{tabular}

FONTE: VERISSIMO, J. 2005.

\section{b) Informação Política}

Noticiário na TV e conversa com amigos apresentaram-se como as principais fontes de informação política dos conselheiros. Quando agregados por Conselhos, percebe-se que os conselheiros de Cidade Tiradentes, em sua maioria (03), disseram sempre participar de reuniões para discutir questões políticas. Quando se olham os dados separados por período de início de participação, os conselheiros dos grupos "período anterior e/ou até 1980" e "entre 1981 e 1992" mostraram-se bastante engajados em atividades que geram informação política, quando comparados ao grupo "depois de 2001". 
Estes - ao contrário dos dois outros grupos que disseram exercer "sempre" todas as atividades -, afirmaram ter por principal fonte de informação política a televisão.

\section{TABELA 09: FREQUÊNCIA DO USO DE FONTES DE INFORMAÇÕES POLÍTICAS, POR CONSELHO DE QUE FAZ PARTE.}

\begin{tabular}{|c|c|c|c|c|c|c|}
\hline \multicolumn{7}{|c|}{$\begin{array}{l}\text { Vou ler uma lista de atividades e gostaria de saber com qual freqüência você as faz. } \\
\text { Com que freqüência você * }\end{array}$} \\
\hline 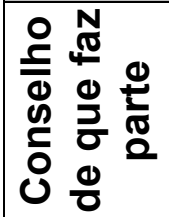 & Atividade & $\begin{array}{c}\text { Assiste } \\
\text { noticiário na } \\
\text { TV }\end{array}$ & $\begin{array}{l}\text { Lê sobre } \\
\text { política nos } \\
\text { jornais }\end{array}$ & $\begin{array}{l}\text { Conversa sobre } \\
\text { política com os } \\
\text { amigos }\end{array}$ & $\begin{array}{c}\text { Participa de } \\
\text { reuniões para } \\
\text { discutir questões } \\
\text { políticas }\end{array}$ & Total \\
\hline \multirow{5}{*}{ 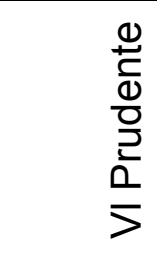 } & sempre & 3 & 2 & 4 & 1 & 10 \\
\hline & às vezes & & 1 & & 1 & 2 \\
\hline & raramente & 1 & & & & 1 \\
\hline & nunca & & 1 & & 2 & 3 \\
\hline & \begin{tabular}{|l|} 
Total \\
\end{tabular} & 4 & 4 & 4 & 4 & 16 \\
\hline & & & & & & \\
\hline & sempre & 2 & 1 & 1 & 2 & 6 \\
\hline & às vezes & 1 & 1 & 2 & & 4 \\
\hline & raramente & 1 & 1 & & 1 & 3 \\
\hline & nunca & & 1 & 1 & 1 & 3 \\
\hline & Total & 4 & 4 & 4 & 4 & 16 \\
\hline \multirow{5}{*}{ 은 $\frac{\stackrel{d}{\frac{d}{c}}}{\frac{d}{0}}$} & sempre & 3 & 1 & 3 & 3 & 10 \\
\hline & às vezes & & & & & \\
\hline & raramente & 1 & 3 & & & 4 \\
\hline & nunca & & & 1 & 1 & 2 \\
\hline & \begin{tabular}{|l|} 
Total \\
\end{tabular} & 4 & 4 & 4 & 4 & 16 \\
\hline & & & & & & \\
\hline \multirow{5}{*}{ 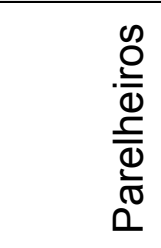 } & sempre & 4 & 4 & 4 & 1 & 13 \\
\hline & às vezes & & & & 2 & 2 \\
\hline & raramente & & & & 1 & 1 \\
\hline & nunca & & & & & \\
\hline & \begin{tabular}{|l|} 
Total \\
\end{tabular} & 4 & 4 & 4 & 4 & 16 \\
\hline
\end{tabular}

FONTE: VERÍSSIMO, J. 2005.

* Respostas múltiplas 


\section{TABELA 9.1: FREQUÊNCIA DO USO DE FONTES DE INFORMAÇÕES POLÍTICAS, POR PERÍODO DE INÍCIO DE PARTICIPAÇÃO.}

\begin{tabular}{|c|c|c|c|c|c|c|}
\hline \multicolumn{7}{|c|}{$\begin{array}{l}\text { Vou ler uma lista de atividades e gostaria de saber com qual freqüência você as faz. } \\
\text { Com que freqüência você * }\end{array}$} \\
\hline $\begin{array}{l}\text { 응 } \\
\frac{0}{2} \\
0 \\
0\end{array}$ & Atividade & $\begin{array}{c}\text { Assiste } \\
\text { noticiário na } \\
\text { TV }\end{array}$ & $\begin{array}{l}\text { Lê sobre } \\
\text { política nos } \\
\text { jornais }\end{array}$ & $\begin{array}{c}\text { Conversa sobre } \\
\text { política com os } \\
\text { amigos }\end{array}$ & $\begin{array}{c}\text { Participa de } \\
\text { reuniões para } \\
\text { discutir questões } \\
\text { políticas }\end{array}$ & Total \\
\hline \multirow{5}{*}{ 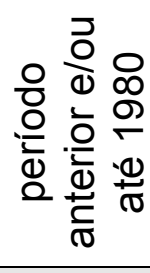 } & sempre & 4 & 4 & 5 & 2 & 15 \\
\hline & às vezes & & & & 3 & 3 \\
\hline & raramente & 1 & 1 & & & 2 \\
\hline & nunca & & & & & \\
\hline & Total & 5 & 5 & 5 & 5 & 20 \\
\hline \multirow{5}{*}{ 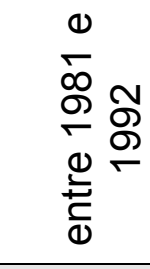 } & sempre & 4 & 3 & 5 & 5 & 17 \\
\hline & às vezes & 1 & 2 & 1 & & 4 \\
\hline & raramente & 1 & 1 & & 1 & 3 \\
\hline & nunca & & & & & \\
\hline & Total & 6 & 6 & 6 & 6 & 24 \\
\hline \multirow{5}{*}{$\begin{array}{l}\frac{0}{0} \\
\frac{\infty}{0} \delta \\
\frac{0}{0} \\
\frac{0}{0}\end{array}$} & sempre & 4 & 1 & 2 & & 7 \\
\hline & às vezes & & & 1 & & 1 \\
\hline & raramente & 1 & 2 & & 1 & 4 \\
\hline & nunca & & 2 & 2 & 4 & 8 \\
\hline & Total & 5 & 5 & 5 & 5 & 20 \\
\hline
\end{tabular}

FONTE: VERÍSSIMO, J. 2005.

* Respostas múltiplas

\section{c) Valores sócio-políticos}

Com relação ao grau de atividade política dos conselheiros, percebeu-se que aqueles de Cidade Tiradentes e Parelheiros (o primeiro com índice de institucionalidade abaixo da mediana e o segundo com este indicador acima desta marca) declararam já terem participado de todas as atividades relacionadas na tabela abaixo de maneira mais ativa do que os de Perus e Vila Prudente. 


\section{TABELA 10: GRAU DE ATIVIDADE POLÍTICA, POR CONSELHO DE QUE FAZ}

PARTE.

\begin{tabular}{|c|c|c|c|c|c|c|c|}
\hline \multicolumn{8}{|c|}{$\begin{array}{c}\text { Vou ler algumas diferentes formas de ação política que as pessoas podem adotar. } \\
\begin{array}{c}\text { Gostaria que você dissesse se já fez alguma dessas ações, se você poderia fazê-las, } \\
\text { ou se nunca, em nenhuma circunstância, faria.* }\end{array}\end{array}$} \\
\hline $\begin{array}{l}\text { Conselho de } \\
\text { que faz parte }\end{array}$ & Atividade & $\begin{array}{l}\text { Assinar } \\
\text { um } \\
\text { manifesto }\end{array}$ & $\begin{array}{l}\text { Participar } \\
\text { de boicote }\end{array}$ & $\begin{array}{l}\text { Participar de } \\
\text { manifestações }\end{array}$ & $\begin{array}{l}\text { Participar } \\
\text { de greves }\end{array}$ & $\begin{array}{l}\text { Ocupar } \\
\text { prédios }\end{array}$ & Total \\
\hline \multirow{4}{*}{ VI Prudente } & Já fez & 3 & 1 & 2 & & & 6 \\
\hline & \begin{tabular}{|l|} 
Poderia \\
fazer
\end{tabular} & 1 & 2 & & 2 & 1 & 6 \\
\hline & Nunca faria & & 1 & 2 & 2 & 3 & 8 \\
\hline & Total & 4 & 4 & 4 & 4 & 4 & 20 \\
\hline \multirow{4}{*}{ Perus } & Já fez & 3 & 2 & 2 & 1 & 1 & 9 \\
\hline & $\begin{array}{l}\text { Poderia } \\
\text { fazer }\end{array}$ & & 2 & 1 & 2 & 1 & 6 \\
\hline & Nunca faria & 1 & & 1 & 1 & 2 & 5 \\
\hline & Total & 4 & 4 & 4 & 4 & 4 & 20 \\
\hline \multirow{5}{*}{$\begin{array}{l}\text { Cid. } \\
\text { Tiradentes }\end{array}$} & & & & & & & \\
\hline & Já fez & 3 & 1 & 4 & 4 & & 12 \\
\hline & $\begin{array}{l}\text { Poderia } \\
\text { fazer }\end{array}$ & 1 & 3 & & & 1 & 5 \\
\hline & Nunca faria & & & & & 3 & 3 \\
\hline & Total & 4 & 4 & 4 & 4 & 4 & 20 \\
\hline & & & & & & & \\
\hline \multirow{4}{*}{ Parelheiros } & Já fez & 3 & 1 & 4 & 3 & 1 & 12 \\
\hline & \begin{tabular}{|l|} 
Poderia \\
fazer
\end{tabular} & & 2 & & & & 2 \\
\hline & Nunca faria & 1 & 1 & & 1 & 3 & 6 \\
\hline & Total & 4 & 4 & 4 & 4 & 4 & 20 \\
\hline
\end{tabular}

FONTE: VERISSIMO, J. 2005.

* Respostas múltiplas

Observando-se por período de início de participação, ficou evidente a diferença entre os grupos "período anterior e/ou até 1980" e "entre 1981 e 1992", que demonstraram ter um grau de atividade política (categoria "já fez" na tabela 10.1) muito superior ao grupo "depois de 2001". Corroborando este dado, a categoria "nunca faria", olhada no grupo "depois de 2001" foi muito superior aos demais grupos. 
TABELA 10.1: GRAU DE ATIVIDADE POLÍTICA, POR PERÍODO DE INÍCIO DE PARTICIPAÇÃO.

\begin{tabular}{|c|c|c|c|c|c|c|c|}
\hline \multicolumn{8}{|c|}{$\begin{array}{c}\text { Vou ler algumas diferentes formas de ação política que as pessoas podem adotar } \\
\text { Gostaria } \begin{array}{c}\text { que você dissesse se já fez alguma dessas ações, se você poderia } \\
\text { fazê-las, ou se nunca, em nenhuma circunstância, faria.* }\end{array}\end{array}$} \\
\hline Período & Atividade & $\begin{array}{c}\text { Assinar um } \\
\text { manifesto }\end{array}$ & $\begin{array}{l}\text { Participar } \\
\text { de boicote }\end{array}$ & $\begin{array}{l}\text { Participar de } \\
\text { manifestações }\end{array}$ & $\begin{array}{l}\text { Participar } \\
\text { de greves }\end{array}$ & $\begin{array}{l}\text { Ocupar } \\
\text { prédios }\end{array}$ & Total \\
\hline \multirow{4}{*}{$\begin{array}{l}\text { período } \\
\text { anterior } \\
\text { e/ou até } \\
1980\end{array}$} & Já fez & 3 & 2 & 5 & 3 & 1 & 14 \\
\hline & \begin{tabular}{|l} 
Poderia \\
fazer
\end{tabular} & 1 & 2 & & 1 & & 4 \\
\hline & Nunca faria & 1 & 1 & & 1 & 4 & 7 \\
\hline & Total & 5 & 5 & 5 & 5 & 5 & 25 \\
\hline & & & & & & & \\
\hline \multirow{4}{*}{$\begin{array}{l}\text { entre } \\
1981 \text { e } \\
1992\end{array}$} & Já fez & 6 & 2 & 6 & 4 & 1 & 19 \\
\hline & \begin{tabular}{|l|}
$\begin{array}{l}\text { Poderia } \\
\text { fazer }\end{array}$ \\
\end{tabular} & & 4 & & 2 & 3 & 9 \\
\hline & Nunca faria & & & & & 2 & 2 \\
\hline & Total & 6 & 6 & 6 & 6 & 6 & 30 \\
\hline & & & & & & & \\
\hline \multirow{4}{*}{$\begin{array}{l}\text { depois } \\
\text { de } 2001\end{array}$} & Já fez & 3 & 1 & 1 & 1 & & 6 \\
\hline & $\begin{array}{l}\begin{array}{l}\text { Poderia } \\
\text { fazer }\end{array} \\
\end{array}$ & 1 & 3 & 1 & 1 & & 6 \\
\hline & Nunca faria & 1 & 1 & 3 & 3 & 5 & 13 \\
\hline & Total & 5 & 5 & 5 & 5 & 5 & 25 \\
\hline
\end{tabular}

FONTE: VERISSIMO, J. 2005.

* Respostas múltiplas

Quando perguntados sobre diversas maneiras de se governar um país, todos julgaram ser uma coisa muito boa (5), ou boa (11), ter um regime democrático. Contudo, 11 deles estimaram que ter técnicos especialistas governando seria um regime muito bom (1), ou bom (10). Chamo a atenção para os conselheiros de Perus, região na qual a totalidade dos respondentes (4) afirmou que ter técnicos governando seria uma coisa boa, e dois deles afirmaram que ter um governo militar seria uma coisa boa. 
TABELA 11: GRAU DE VALORES DEMOCRÁTICOS, POR CONSELHO DE QUE FAZ PARTE.

\begin{tabular}{|l|l|c|c|c|c|}
\hline \multicolumn{4}{|c}{ O que você pensa de cada uma dessas maneiras de governar um país? } \\
\hline \multirow{4}{*}{$\begin{array}{l}\text { Conselho de } \\
\text { que faz parte }\end{array}$} & Atividade & $\begin{array}{c}\text { Ter líder que } \\
\text { não tenha que } \\
\text { se preocupar } \\
\text { com o } \\
\text { Congresso }\end{array}$ & $\begin{array}{c}\text { Técnicos } \\
\text { especialistas } \\
\text { governando }\end{array}$ & $\begin{array}{c}\text { Ter } \\
\text { governo } \\
\text { militar }\end{array}$ & $\begin{array}{c}\text { Ter regime } \\
\text { democrático }\end{array}$ \\
\hline \multirow{4}{*}{ VI. Prudente } & Muito boa & 1 & & 1 & 2 \\
\hline & Boa & & 1 & & 2 \\
\hline & Ruim & 1 & 3 & 1 & \\
\hline & Muito Ruim & 2 & & 2 & \\
\hline \multirow{5}{*}{ Perus } & Muito boa & & & & 1 \\
\hline & Boa & 1 & 4 & 2 & 3 \\
\hline & Ruim & & & & \\
\hline & Muito Ruim & 3 & & 2 & \\
\hline Cid. Tiradentes & Muito boa & & & & 1 \\
\hline & Boa & 2 & 3 & 1 & 3 \\
\hline & Ruim & 1 & & 1 & \\
\hline & Muito Ruim & 1 & 1 & 2 & \\
\hline \multirow{5}{*}{ Parelheiros } & Muito boa & & 1 & & 1 \\
\cline { 2 - 7 } & Boa & 1 & 2 & & 3 \\
\hline & Ruim & & & 3 & \\
\hline & Muito Ruim & 3 & 1 & 1 & \\
\hline
\end{tabular}

FONTE: VERISSIMO, J. 2005.

Analisados por período de início de participação, os conselheiros do grupo "depois de 2001" apresentaram uma certa predileção por um regime militar, tendo afirmado, 03 de 05 deles, ser este tipo de regime uma coisa boa. Dois deles julgaram bom (1) e muito bom (1) ter um líder forte que não se preocupe com o Congresso, e três responderam que ter técnicos especialistas no governo seria uma coisa boa. 
TABELA 11.1: GRAU DE VALORES DEMOCRÁTICOS, POR PERÍODO DE INÍCIO DE PARTICIPAÇÃO.

\begin{tabular}{|c|c|c|c|c|c|}
\hline \multicolumn{6}{|c|}{ O que você pensa de cada uma dessas maneiras de governar um país? } \\
\hline Período & Atividade & $\begin{array}{c}\text { Ter líder que } \\
\text { não tenha que } \\
\text { se preocupar } \\
\text { com o } \\
\text { Congresso }\end{array}$ & $\begin{array}{c}\text { Técnicos } \\
\text { especialistas } \\
\text { governando }\end{array}$ & $\begin{array}{c}\text { Ter } \\
\text { governo } \\
\text { militar }\end{array}$ & $\begin{array}{l}\text { Ter regime } \\
\text { democrático }\end{array}$ \\
\hline \multirow{4}{*}{$\begin{array}{c}\text { Período } \\
\text { anterior } \\
\text { e/ou até } \\
1980\end{array}$} & Muito boa & 0 & & & 3 \\
\hline & Boa & 1 & 3 & 1 & 2 \\
\hline & Ruim & 0 & & 1 & \\
\hline & Muito Ruim & 4 & 2 & 3 & \\
\hline \multirow{4}{*}{$\begin{array}{l}\text { entre } 1981 \\
\text { e } 1992\end{array}$} & Muito boa & 0 & 1 & & 1 \\
\hline & Boa & 2 & 4 & & 5 \\
\hline & \begin{tabular}{|l|} 
Ruim \\
\end{tabular} & 1 & 1 & 3 & \\
\hline & Muito Ruim & 3 & & 3 & \\
\hline \multirow{4}{*}{$\begin{array}{c}\text { depois de } \\
2001\end{array}$} & Muito boa & 1 & & & 1 \\
\hline & Boa & 1 & 3 & 3 & 4 \\
\hline & Ruim & 1 & 2 & 1 & \\
\hline & Muito Ruim & 2 & & 1 & \\
\hline
\end{tabular}

FONTE: VERÍSSIMO, J. 2005.

Em relação ao nível de orgulho nacional dos conselheiros, estes se mostraram, em geral, muito orgulhosos (6) ou orgulhosos (7) de serem brasileiros. Se olhados agregados por Conselho, vê-se que Vila Prudente (que é o Conselho com o menor índice de institucionalidade: 0,42 ) obteve o maior número de conselheiros que se declararam muito orgulhosos com sua nacionalidade.

TABELA 12: ORGULHO NACIONAL, POR CONSELHO DE QUE FAZ PARTE.

\begin{tabular}{|l|c|c|c|c|}
\hline \multicolumn{5}{|c|}{ E em relação a ser brasileiro(a)? Como você se considera? } \\
\hline $\begin{array}{l}\text { Conselho de } \\
\text { que faz parte }\end{array}$ & muito orgulhoso & orgulhoso & não muito orgulhoso & Total \\
\hline Vl. Prudente & 4 & & & 4 \\
\hline Perus & 1 & 2 & 1 & 4 \\
\hline Cid \\
Tiradentes & 1 & 2 & 1 & 4 \\
\hline Parelheiros & & 3 & 1 & 4 \\
\hline Total & 6 & 7 & 3 & 16 \\
\hline
\end{tabular}

FONTE: VERISSIMO, J. 2005. 
Já se agregados por período de início de participação, pode-se ler nas tabelas que o grupo que se mostrou mais orgulhoso de ser brasileiro foi o grupo que iniciou sua participação depois de 2001.

TABELA 12.1: ORGULHO NACIONAL, POR PERÍODO DE INÍCIO DE PARTICIPAÇÃO.

\begin{tabular}{|l|c|c|c|c|}
\hline \multicolumn{5}{|c|}{ E em relação a ser brasileiro(a)? Como você se considera? } \\
\hline Período & muito orgulhoso & orgulhoso & não muito orgulhoso & Total \\
\hline $\begin{array}{l}\text { período anterior e/ou } \\
\text { até 1980 }\end{array}$ & 1 & 2 & 2 & 5 \\
\hline entre 1981 e 1992 & 1 & 4 & 1 & 6 \\
\hline depois de 2001 & 4 & 1 & 0 & 5 \\
\hline Total & 6 & 7 & 3 & 16 \\
\hline
\end{tabular}

FONTE: VERISSIMO, J. 2005.

A política indicou despertar bons sentimentos à maioria dos conselheiros: entusiasmo (4), interesse (2), paixão (1), compromisso (5). Apenas quatro deles disseram que ela suscita desgosto (1) e desconfiança (3). Se olhados agrupados por Conselho vê-se que Perus (que obteve o segundo maior índice de institucionalidade: 0,70 ) alcançou o maior número de pessoas que se disseram desconfiadas da política (2).

\section{TABELA 13: SENTIMENTO EM RELAÇÃO À POLÍTICA, POR CONSELHO DE QUE FAZ PARTE.}

Todos temos diferentes sentimentos em relação à política. Em você, a política causa

\begin{tabular}{|l|c|c|c|c|c|c|c|}
\hline $\begin{array}{l}\text { Conselho de } \\
\text { que faz } \\
\text { parte }\end{array}$ & entusiasmo & interesse & paixão & desgosto & compromisso & desconfiança & Total \\
\hline Vl. prudente & 2 & & 1 & & & 1 & 4 \\
\hline Perus & & 1 & & & 1 & 2 & 4 \\
\hline $\begin{array}{l}\text { Cid. } \\
\text { Tiradentes }\end{array}$ & 1 & & & 1 & 2 & & 4 \\
\hline Parelheiros & 1 & 1 & & & 2 & & 4 \\
\hline Total & 4 & 2 & 1 & 1 & 5 & 3 & 16 \\
\hline
\end{tabular}

FONTE: VERISSIMO, J. 2005. 
Já se agregados por período de início de participação, percebe-se que o grupo que iniciou suas atividades associativas depois de 2001 avaliou a política de maneira menos otimista: de cinco conselheiros um deles disse sentir-se desgostoso com a política e três desconfiados em relação à ela.

\section{TABELA 13.1: SENTIMENTO EM RELAÇÃO À POLÍTICA, POR PERÍODO DE INÍCIO DE PARTICIPAÇÃO.}

\begin{tabular}{|l|c|c|c|c|c|c|c|}
\hline \multicolumn{7}{|c|}{ Todos temos diferentes sentimentos em relação à política. Em você, a política causa } \\
\hline $\begin{array}{l}\text { Conselho de } \\
\text { que faz parte }\end{array}$ & entusiasmo & interesse & paixão & desgosto & compromisso & desconfiança & Total \\
\hline $\begin{array}{l}\text { período } \\
\text { anterior e/ou } \\
\text { até 1980 }\end{array}$ & 3 & & & & 2 & & 5 \\
\hline $\begin{array}{l}\text { entre 1981 e } \\
1992\end{array}$ & 1 & 2 & & & 3 & & 6 \\
\hline $\begin{array}{l}\text { depois de } \\
2001\end{array}$ & & & 1 & 1 & & 3 & 5 \\
\hline Total & 4 & 2 & 1 & 1 & 5 & 3 & 16 \\
\hline
\end{tabular}

FONTE: VERISSIMO, J. 2005.

\section{d) Participação e Associativismo ${ }^{34}$}

Foram apresentadas diversas associações para os conselheiros responderem se delas participaram formalmente, esporadicamente, ou se já participaram e não participam mais. Percebe-se em Vila Prudente que tanto a participação formal (8) quanto a esporádica (7) mostraram-se menores do que a dos conselheiros das outras regiões: Perus (11 e 08), Cidade Tiradentes (12 e 09), e de Parelheiros (11 e 08). Os conselheiros daquele Conselho também apresentaram menor diversidade de instituições nas quais participam e/ou participaram (07 tipos), se comparados com os de Perus (14), Cidade Tiradentes (11), e os de Parelheiros (10).

\footnotetext{
${ }^{34}$ As respostas das tabelas desta seção são múltiplas.
} 


\section{TABELA 14: NÚMERO DE ASSOCIAÇÕES DAS QUAIS FAZEM PARTE OS CONSELHEIROS DE VILA PRUDENTE.}

\begin{tabular}{|l|c|c|c|c|}
\hline \multicolumn{4}{|c|}{ Vila Prudente - Você participa de: } \\
\hline Associação / escala & formalmente & esporadicamente & $\begin{array}{c}\text { já } \\
\text { participei }\end{array}$ & não \\
\hline Entidade beneficente & 1 & & & 3 \\
\hline Associação recreativa/esportiva & & 1 & & 3 \\
\hline Associação de defesa dos Direitos Humanos & 1 & 1 & & 2 \\
\hline Defesa dos Consumidores & & & & 2 \\
\hline Associação religiosa & 1 & 1 & & 3 \\
\hline Grupos de Fé e política & 1 & & 1 & 3 \\
\hline Associações de Moradia & & 1 & & 1 \\
\hline Partido Político & 1 & 1 & & 3 \\
\hline Associação de Saúde & 3 & & & 4 \\
\hline Associação ligada a educação & & & & 4 \\
\hline Associação de meio ambiente & & & & 4 \\
\hline Associação de cultura & & & & 4 \\
\hline Entidade empresarial/patronal & & & & 4 \\
\hline Entidade estudantil & & & & 3 \\
\hline Associação de auto-ajuda & & & 1 & 56 \\
\hline Sindicato de trabalhadores & & & & \\
\hline Associação profissional & 8 & 7 & & \\
\hline Outros tipos de associações & & & & \\
\hline Total & & & & \\
\hline
\end{tabular}

FONTE: VERÍSSIMO, J. 2005. 


\section{TABELA 14.1: NÚMERO DE ASSOCIAÇÕES DAS QUAIS FAZEM PARTE OS CONSELHEIROS DE PERUS.}

\begin{tabular}{|l|c|c|c|c|}
\hline \multicolumn{4}{|c|}{ Perus - Você participa de: } \\
\hline Associação / escala & formalmente & esporadicamente & $\begin{array}{c}\text { já } \\
\text { participei }\end{array}$ & não \\
\hline Entidade beneficente & 1 & & 1 & 2 \\
\hline Associação recreativa/esportiva & & 1 & 1 & 3 \\
\hline Associação de defesa dos Direitos Humanos & 1 & & & 4 \\
\hline Defesa dos Consumidores & & & & 3 \\
\hline Associação religiosa & & 1 & & 2 \\
\hline Grupos de Fé e política & 2 & & 1 & 2 \\
\hline Associações de Moradia & & 1 & & 1 \\
\hline Partido Político & & & & 3 \\
\hline Associação de Saúde & 3 & & & 3 \\
\hline Associação ligada a educação & & & & 4 \\
\hline Associação de meio ambiente & 1 & & & 4 \\
\hline Associação de cultura & & & & 4 \\
\hline Entidade empresarial/patronal & & & & 3 \\
\hline Entidade estudantil & 1 & 1 & & 3 \\
\hline Associação de auto-ajuda & 1 & & 3 & 50 \\
\hline Sindicato de trabalhadores & 1 & & & \\
\hline Associação profissional & 11 & & & \\
\hline Outros tipos de associações & & & & \\
\hline Total & & & & \\
\hline
\end{tabular}

FONTE: VERÍSSIMO, J. 2005. 


\section{TABELA 14.1.2: NÚMERO DE ASSOCIAÇÕES DAS QUAIS FAZEM PARTE OS CONSELHEIROS DE CIDADE TIRADENTES.}

\begin{tabular}{|l|c|c|c|c|}
\hline \multicolumn{4}{|c|}{ Cidade Tiradentes - Você participa de: } \\
\hline Associação / escala & formalmente & esporadicamente & $\begin{array}{c}\text { já } \\
\text { participei }\end{array}$ & não \\
\hline Entidade beneficente & 1 & & & 3 \\
\hline Associação recreativa/esportiva & & 1 & & 3 \\
\hline Associação de defesa dos Direitos Humanos & 1 & 1 & & 2 \\
\hline Defesa dos Consumidores & & & & 2 \\
\hline Associação religiosa & 2 & & & 1 \\
\hline Grupos de Fé e política & 1 & 2 & & 2 \\
\hline Associações de Moradia & 1 & 1 & & 1 \\
\hline Partido Político & 2 & 1 & & 2 \\
\hline Associação de Saúde & 2 & & & 3 \\
\hline Associação ligada a educação & 2 & 1 & & 3 \\
\hline Associação de meio ambiente & & 1 & & 4 \\
\hline Associação de cultura & & & & 4 \\
\hline Entidade empresarial/patronal & & & & 4 \\
\hline Entidade estudantil & & & & 2 \\
\hline Associação de auto-ajuda & & & 1 & 3 \\
\hline Sindicato de trabalhadores & & & 3 & 48 \\
\hline Associação profissional & & & & \\
\hline Outros tipos de associações & 12 & 9 & & \\
\hline Total & & & & \\
\hline
\end{tabular}

FONTE: VERÍSSIMO, J. 2005. 


\section{TABELA 14.1.3: NÚMERO DE ASSOCIAÇÕES DAS QUAIS FAZEM PARTE OS CONSELHEIROS DE PARELHEIROS.}

\begin{tabular}{|l|c|c|c|c|}
\hline \multicolumn{5}{|c|}{ Parelheiros - Você participa de: } \\
\hline Associação / escala & formalmente & esporadicamente & $\begin{array}{c}\text { já } \\
\text { participei }\end{array}$ & não \\
\hline Entidade beneficente & 1 & & & 3 \\
\hline Associação recreativa/esportiva & 1 & & & 3 \\
\hline Associação de defesa dos Direitos Humanos & 1 & 2 & & 1 \\
\hline Defesa dos Consumidores & 1 & & & 2 \\
\hline Associação religiosa & 2 & & 2 & 1 \\
\hline Grupos de Fé e política & 1 & & & 1 \\
\hline Associações de Moradia & 3 & & & 2 \\
\hline Partido Político & & 2 & 1 & 1 \\
\hline Associação de Saúde & & & & 1 \\
\hline Associação ligada a educação & 1 & & & 4 \\
\hline Associação de meio ambiente & & 3 & & 4 \\
\hline Associação de cultura & & & & 4 \\
\hline Entidade empresarial/patronal & & & & 2 \\
\hline Entidade estudantil & & & & 4 \\
\hline Associação de auto-ajuda & & & & 4 \\
\hline Sindicato de trabalhadores & & & 5 & 48 \\
\hline Associação profissional & 11 & & & \\
\hline Outros tipos de associações & & & & \\
\hline Total & & & & \\
\hline
\end{tabular}

FONTE: VERÍSSIMO, J. 2005.

Estas diferenças saltaram aos olhos quando se compararam os grupos de ano de início de participação. Os conselheiros que iniciaram a vida associativa no período anterior e/ou até 1980 afirmaram participar intensamente de diversos tipos de associações (13), e de maneira freqüente: formalmente 18, e esporadicamente 11 . 


\section{TABELA 14.2: NÚMERO DE ASSOCIAÇÕES DAS QUAIS FAZEM PARTE OS CONSELHEIROS QUE INICIARAM SUA PARTICIPAÇÃO NO PERÍODO ANTERIOR E/OU ATÉ 1980.}

\begin{tabular}{|c|c|c|c|c|}
\hline \multicolumn{5}{|c|}{ período anterior e/ou até 1980 - Você participa de: } \\
\hline Associação / escala & formalmente & esporadicamente & $\begin{array}{c}\text { já } \\
\text { participei }\end{array}$ & não \\
\hline Entidade beneficente & 1 & & 1 & 3 \\
\hline Associação recreativa/esportiva & & & & 5 \\
\hline Associação de defesa dos Direitos Humanos & 2 & 2 & & 1 \\
\hline Defesa dos Consumidores & 1 & & & 4 \\
\hline Associação religiosa & 3 & 1 & & 1 \\
\hline Grupos de Fé e política & 2 & 2 & & 1 \\
\hline Associações de Moradia & 1 & & & 4 \\
\hline Partido Político & 1 & 2 & 2 & \\
\hline Associação de Saúde & 2 & & & 3 \\
\hline Associação ligada a educação & 2 & 1 & 1 & 1 \\
\hline Associação de meio ambiente & & 3 & & 2 \\
\hline Associação de cultura & & & & 5 \\
\hline Entidade empresarial/patronal & & & & 5 \\
\hline Entidade estudantil & & & & 5 \\
\hline Associação de auto-ajuda & & & & 5 \\
\hline Sindicato de trabalhadores & 1 & & 3 & 1 \\
\hline Associação profissional & 1 & & & 4 \\
\hline Outros tipos de associações & 1 & & 1 & 3 \\
\hline Total & 18 & 11 & 8 & 53 \\
\hline
\end{tabular}

FONTE: VERÍSSIMO, J. 2005.

Com o grupo "entre 1981 e 1992" a situação se aproxima: são 12 diferentes tipos de associações e uma participação mais freqüente que a do grupo anterior: 21 respostas de participação formal e 18 de esporádica. 
TABELA 14.2.1: NÚMERO DE ASSOCIAÇÕES DAS QUAIS FAZEM PARTE OS CONSELHEIROS QUE INICIARAM SUA PARTICIPAÇÃO ENTRE 1981 E 1992.

\begin{tabular}{|l|c|c|c|c|}
\hline \multicolumn{4}{|c|}{ entre 1981 e 1992 - Você participa de: } \\
\hline Associação / escala & formalmente & esporadicamente & $\begin{array}{c}\text { já } \\
\text { participei }\end{array}$ & não \\
\hline Entidade beneficente & 2 & & 1 & 4 \\
\hline Associação recreativa/esportiva & 1 & 1 & & 4 \\
\hline Associação de defesa dos Direitos Humanos & 2 & 2 & & 2 \\
\hline Defesa dos Consumidores & & & & 2 \\
\hline Associação religiosa & 4 & & & 1 \\
\hline Grupos de Fé e política & 3 & 2 & & 1 \\
\hline Associações de Moradia & 2 & 3 & 1 & 3 \\
\hline Partido Político & 2 & 3 & & 3 \\
\hline Associação de Saúde & 3 & & & 4 \\
\hline Associação ligada a educação & 1 & 2 & & 6 \\
\hline Associação de meio ambiente & & 3 & & 6 \\
\hline Associação de cultura & 1 & 1 & & 6 \\
\hline Entidade empresarial/patronal & & & & 4 \\
\hline Entidade estudantil & & & & 6 \\
\hline Associação de auto-ajuda & & & & 67 \\
\hline Sindicato de trabalhadores & & & & \\
\hline Associação profissional & & & & \\
\hline Outros tipos de associações & 21 & 18 & & \\
\hline Total & & & & \\
\hline
\end{tabular}

FONTE: VERÍSSIMO, J. 2005.

Já os conselheiros agregados por terem iniciado sua participação depois de 2001 disseram fazer parte de poucas associações (07 tipos) e as freqüentaram de maneira não tão freqüente em relação aos conselheiros dos outros agrupamentos: 06 respostas de participação formal e 03 de esporádicas. 
TABELA 14.2.3: NÚMERO DE ASSOCIAÇÕES DAS QUAIS FAZEM PARTE OS CONSELHEIROS QUE INICIARAM SUA PARTICIPAÇÃO DEPOIS DE 2001.

\begin{tabular}{|l|c|c|c|c|}
\hline \multicolumn{5}{|c|}{ depois de 2001 - Você participa de: } \\
\hline Associação / escala & formalmente & esporadicamente & $\begin{array}{c}\text { já } \\
\text { participei }\end{array}$ & não \\
\hline Entidade beneficente & 1 & & & 4 \\
\hline Associação recreativa/esportiva & & 1 & 1 & 4 \\
\hline Associação de defesa dos Direitos Humanos & & & & 5 \\
\hline Defesa dos Consumidores & & & & 3 \\
\hline Associação religiosa & 1 & 1 & 1 & 3 \\
\hline Grupos de Fé e política & & & & 5 \\
\hline Associações de Moradia & 1 & & & 2 \\
\hline Partido Político & & & & 5 \\
\hline Associação de Saúde & 3 & & & 5 \\
\hline Associação ligada a educação & & & & 5 \\
\hline Associação de meio ambiente & & & & 5 \\
\hline Associação de cultura & & & & 5 \\
\hline Entidade empresarial/patronal & & & & 5 \\
\hline Entidade estudantil & & & & 4 \\
\hline Associação de auto-ajuda & & & & 79 \\
\hline Sindicato de trabalhadores & & & & \\
\hline Associação profissional & & & & \\
\hline Outros tipos de associações & & & & \\
\hline Total & & & & \\
\hline
\end{tabular}

FONTE: VERÍSSIMO, J. 2005.

\section{e) Tolerância}

Em relação à tolerância à homossexualidade percebe-se - à pequena exceção dos conselheiros de Parelheiros (que é o Conselho com maior índice institucional: $0,84)$-, que esta mostrou-se uma situação bastante tolerável pelos conselheiros de todos os Conselhos estudados. Já quando se falou em aborto, o quadro se inverteu e vê-se uma situação bastante conservadora, tendo 11 dos 16 conselheiros se posicionado como esta sendo uma atitude "nunca aceitável". 
TABELA 15: TOLERÂNCIA AO ABORTO E À HOMOSSEXUALIDADE, POR CONSELHO DE QUE FAZ PARTE.

\begin{tabular}{|c|c|c|c|c|c|c|c|c|c|c|c|}
\hline \multicolumn{12}{|c|}{$\begin{array}{l}\text { Você pensa que a homossexualidade e o aborto são sempre } \\
\text { aceitáveis, nunca aceitáveis, ou você tem alguma opinião } \\
\text { intermediária? }\end{array}$} \\
\hline categ. & $\begin{array}{l}\text { Conselho de que faz } \\
\text { parte / escala }\end{array}$ & 1 & 2 & 34 & 45 & 6 & & 8 & 9 & 10 & Total \\
\hline \multirow{4}{*}{ Homo } & VI. Prudente & & & & & & & & & 4 & 4 \\
\hline & Perus & & & & & & & & 1 & 3 & 4 \\
\hline & Cid. Tiradentes & & 1 & 1 & 11 & & & & & 1 & 4 \\
\hline & Parelheiros & & & & 2 & & & 1 & & & 4 \\
\hline \multirow{4}{*}{ Aborto } & VI Prudente & 3 & & 1 & & & & & & & 4 \\
\hline & Perus & 2 & & & 2 & & & & & & 4 \\
\hline & Cid Tiradentes & 1 & 1 & & 2 & & & & & & 4 \\
\hline & Parelheiros & 3 & & & & 1 & & & & & 4 \\
\hline
\end{tabular}

FONTE: VERÍSSIMO, J. 2005.

Percebe-se que esta não é uma questão que varia quando se muda a agregação dos dados. O aborto permaneceu sendo o oposto da homossexualidade, como uma prática nunca aceitável pelos conselheiros dos três grupos abaixo. A maior freqüência de conselheiros que julgaram a prática nunca aceitável (posição 01 na escala) está no grupo "depois de 2001".

TABELA 15.1: TOLERÂNCIA AO ABORTO E À HOMOSSEXUALIDADE, POR PERÍODO DE INÍCIO DE PARTICIPAÇÃO.

\begin{tabular}{|c|c|c|c|c|c|c|c|c|c|c|c|}
\hline \multicolumn{12}{|c|}{$\begin{array}{c}\text { Você pensa que a homossexualidade e o aborto são sempre } \\
\text { aceitáveis, nunca aceitáveis, ou você tem alguma opinião } \\
\text { intermediária? }\end{array}$} \\
\hline categ. & Período / escala & 1 & 2 & 3 & 4 & 5 & 6 & $7 \varepsilon$ & 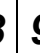 & & Total \\
\hline \multirow{3}{*}{ Homo } & período anterior e/ou até 1980 & & 1 & & & 1 & . & 1 & & & 4 \\
\hline & entre 1981 e 1992 & & & & 1 & 2 & & 1 & 1 & & 4 \\
\hline & depois de 2001 & & & & & & & & & & 4 \\
\hline \multirow{4}{*}{ Aborto } & & & & & & & & & & & \\
\hline & período anterior e/ou até 1980 & 3 & 1 & & & 1 & & & & & 4 \\
\hline & entre 1981 e 1992 & 2 & & 1 & & & 1 & & & & 4 \\
\hline & depois de 2001 & 4 & & & & 1 & & & & & 4 \\
\hline
\end{tabular}

FONTE: VERISSIMO, J. 2005. 


\section{f) Capital Social}

Conversar com os vizinhos diariamente foi uma prática que a maioria dos conselheiros entrevistados (9) afirmou ter. À exceção de Perus, onde a conversa mostrou-se ser mais espaçada no tempo: a maioria dos conselheiros (3) respondeu que fala com seus vizinhos semanalmente.

TABELA 16: FREQUÊNCIA DE CONVERSA COM VIZINHOS, POR CONSELHO.

\begin{tabular}{|l|c|c|c|}
\hline \multicolumn{4}{|c|}{ Com que freqüencia você conversa com seus } \\
vizinhos?
\end{tabular}

FONTE: VERISSIMO, J. 2005.

Agregados por período de início de participação, os conselheiros que iniciaram sua participação em 2001 afirmaram ter o hábito da conversar diariamente com os vizinhos menos arraigado do que os conselheiros dos outros dois grupos.

\section{TABELA 16.1: FREQUÊNCIA DE CONVERSA COM VIZINHOS, POR PERÍODO} DE INÍCIO DE PARTICIPAÇÃO.

\begin{tabular}{|l|c|c|c|}
\hline \multicolumn{4}{|c|}{ Com que freqüência você conversa com seus vizinhos? } \\
\hline Período & todos os dias & toda semana & Total \\
\hline $\begin{array}{l}\text { período anterior } \\
\text { e/ou até 1980 }\end{array}$ & 4 & 1 & 5 \\
\hline entre 1980 e 1992 & 5 & 1 & 6 \\
\hline depois de 2001 & & 5 & 5 \\
\hline Total & 9 & 7 & 16 \\
\hline
\end{tabular}

FONTE: VERISSIMO, J. 2005. 
Os favores entre vizinhos demonstraram acontecer menos entre os conselheiros Vila Prudente do que entre os das demais regiões. Nestas, 08 conselheiros afirmaram que favores acontecem sempre, e quatro que ocorrem às vezes. Cidade Tiradentes (que detém o segundo mais baixo indicador de institucionalidade: 0,61 ) foi o CGS onde os conselheiros mais responderam que os vizinhos se fazem favores sempre (04).

\section{TABELA 17: FREQUÊNCIA DE FAVORES ENTRE VIZINHOS, POR CONSELHO DE QUE FAZ PARTE.}

\begin{tabular}{|l|c|c|c|c|c|}
\hline \multicolumn{7}{|c|}{ freqüência de favores entre vizinhos } \\
\hline $\begin{array}{l}\text { Conselho de } \\
\text { que faz parte }\end{array}$ & sempre & $\begin{array}{c}\text { às } \\
\text { vezes }\end{array}$ & raramente & nunca & Total \\
\hline VI Prudente & & 1 & 1 & 2 & 4 \\
\hline Perus & 2 & 2 & & & 4 \\
\hline $\begin{array}{l}\text { Cid } \\
\text { Tiradentes }\end{array}$ & 4 & & & & 4 \\
\hline Parelheiros & 2 & 1 & & 1 & 4 \\
\hline Total & 8 & 4 & 1 & 3 & 16 \\
\hline
\end{tabular}

FONTE: VERISSIMO, J. 2005.

Estes números pouco se alteraram quando agregados por ano do início da participação dos conselheiros. Destaca-se, contudo, o grupo "entre 1981 e 1992", no qual os conselheiros afirmaram que os vizinhos se fazem favores uns aos outros sempre (04) e às vezes (02) com mais freqüência que os dois outros grupos.

\section{TABELA 17.2: FREQUÊNCIA DE FAVORES ENTRE VIZINHOS, POR PERÍODO DE INÍCIO DE PARTICIPAÇÃO.}

\begin{tabular}{|l|c|c|c|c|c|}
\hline \multicolumn{5}{|c|}{ freqüência de favores entre vizinhos } \\
\hline Grupo & sempre & $\begin{array}{c}\text { às } \\
\text { vezes }\end{array}$ & raramente & nunca & Total \\
\hline $\begin{array}{l}\text { período anterior e/ou } \\
\text { até 1980 }\end{array}$ & 2 & 1 & 1 & 1 & 4 \\
\hline entre 1980 e 1992 & 4 & 2 & & & 4 \\
\hline depois de 2001 & 2 & 1 & & 2 & 4 \\
\hline Total & 8 & 4 & 1 & 3 & 16 \\
\hline
\end{tabular}

FONTE: VERISSIMO, J. 2005. 
Perguntados se se reuniram com amigos ou órgãos públicos para resolverem problemas do bairro ou cidade nos últimos 12 meses, percebe-se que estas práticas apresentaram freqüências muito comuns entre os conselheiros das quatro regiões estudadas. Apenas os conselheiros de Vila Prudente, em sua maioria, disseram não ter participado de reuniões com vizinhos.

\section{TABELA 18: FREQUÊNCIA DE REUNIÕES COMUNITÁRIAS, POR CONSELHO DE QUE FAZ PARTE.}

\begin{tabular}{|l|c|c||c|c||c|}
\hline \multicolumn{4}{|c|}{$\begin{array}{c}\text { Nos últimos } 12 \text { meses você se reuniu para resolver } \\
\text { problemas do seu bairro ou cidade? }\end{array}$} \\
\hline $\begin{array}{l}\text { Conselho de que } \\
\text { faz parte }\end{array}$ & $\begin{array}{c}\text { órgãos } \\
\text { públicos }\end{array}$ & \multicolumn{2}{c|}{$\begin{array}{c}\text { com } \\
\text { vizinhos }\end{array}$} & \multirow{2}{*}{ Total } \\
\cline { 2 - 5 } & sim & não & sim & não & \\
\hline VI Prudente & 3 & 1 & 1 & 3 & 4 \\
\hline Perus & 4 & & 4 & & 4 \\
\hline Cid Tiradentes & 4 & & 4 & & 4 \\
\hline Parelheiros & 4 & & 4 & & 4 \\
\hline Total & 15 & 1 & 13 & 3 & 16 \\
\hline
\end{tabular}

FONTE: VERÍSSIMO, J. 2005.

Mudando-se a agregação dos dados, vê-se que a variação das informações é muito pequena, devendo-se chamar a atenção para dois conselheiros do grupo "depois de 2001" que não participaram de reuniões comunitárias.

TABELA 18.1: FREQUÊNCIA DE REUNIÕES COMUNITÁRIAS, POR PERÍODO DE INÍCIO DE PARTICIPAÇÃO.

\begin{tabular}{|l|c|c||c|c||c|}
\hline Nos últimos 12 meses você se reuniu para resolver problemas do \\
seu bairro ou cidade?
\end{tabular}

FONTE: VERÍSSIMO, J. 2005. 
Ao se avaliar a vida social dos conselheiros de Vila Prudente percebe-se que estes afirmaram que seu lazer está mais concentrado na ida à casa de amigos e parentes, bares, festas e à igreja. Também se nota que a prática de esportes e a ida ao cinema mostraram-se práticas de descanso incomuns entre eles.

\section{TABELA 19: AVALIAÇÃO DA VIDA SOCIAL DOS CONSELHEIROS DE VILA PRUDENTE.}

\begin{tabular}{|l|c|c|c|c|c|}
\hline \multicolumn{6}{|c|}{$\begin{array}{l}\text { Vou apresentar algumas atividades que você pode fazer durante } \\
\text { o seu tempo livre ou de lazer. Eu gostaria de saber se você }\end{array}$} \\
\hline Atividade & Sempre & $\begin{array}{c}\text { Às } \\
\text { vezes }\end{array}$ & Raramente & Nunca & Total \\
\hline $\begin{array}{l}\text { a. Visita amigos e } \\
\text { parentes }\end{array}$ & 1 & 2 & 1 & 0 & 4 \\
\hline $\begin{array}{l}\text { b. Vai a bares ou } \\
\text { restaurantes }\end{array}$ & 1 & 2 & 1 & 0 & 4 \\
\hline $\begin{array}{l}\text { c. Vai ao cinema } \\
\text { d. Vai a festas } \\
\text { (de amigos, } \\
\text { parentes, de } \\
\text { igreja, de } \\
\text { associações, etc) }\end{array}$ & 0 & 0 & 3 & 1 & 4 \\
\hline $\begin{array}{l}\text { e. Passeia em } \\
\text { praças }\end{array}$ & 1 & 2 & 0 & 1 & 4 \\
\hline $\begin{array}{l}\text { f. Passeia em } \\
\text { cachoeiras, } \\
\text { reservas naturais }\end{array}$ & 1 & 0 & 1 & 2 & 4 \\
\hline $\begin{array}{l}\text { g. Pratica } \\
\text { esportes ou fazer } \\
\text { exercícios }\end{array}$ & 1 & 0 & 0 & 3 & 4 \\
\hline $\begin{array}{l}\text { h. Vai ao estádio } \\
\text { de futebol }\end{array}$ & 1 & 0 & 1 & 2 & 4 \\
\hline i. Vai à Igreja & 2 & 1 & 1 & 0 & 4 \\
\hline
\end{tabular}

FONTE: VERISSIMO, J. 2005. 
O padrão é praticamente o mesmo entre os conselheiros de Perus, somando-se às práticas de lazer já citadas, a prática de esportes ("sempre realizada" por 02 dos 04 conselheiros). Para os conselheiros desta região a igreja mostrou-se o principal meio de sociabilidade (03 conselheiros afirmaram freqüentá-la sempre).

\section{TABELA 19.1: AVALIAÇÃO DA VIDA SOCIAL DOS CONSELHEIROS DE PERUS.}

\begin{tabular}{|l|c|c|c|c|c|}
\hline \multicolumn{6}{|c|}{$\begin{array}{l}\text { Vou apresentar algumas atividades que você pode fazer durante o seu } \\
\text { tempo livre ou de lazer. Eu gostaria de saber secê }\end{array}$} \\
\hline Atividade & Sempre & $\begin{array}{c}\text { Às } \\
\text { vezes }\end{array}$ & Raramente & Nunca & Total \\
\hline $\begin{array}{l}\text { a. Visita amigos e } \\
\text { parentes }\end{array}$ & & 3 & 1 & & 4 \\
\hline $\begin{array}{l}\text { b. Vai a bares ou } \\
\text { restaurantes }\end{array}$ & 1 & 2 & 1 & & 4 \\
\hline c. Vai ao cinema & & 1 & 1 & 2 & 4 \\
\hline $\begin{array}{l}\text { d. Vai a festas (de } \\
\text { amigos, parentes, de } \\
\text { igreja, de associações, } \\
\text { etc) }\end{array}$ & 2 & 2 & & & 4 \\
\hline $\begin{array}{l}\text { e. Passeia em praças } \\
\text { f. Passeia em } \\
\text { cachoeiras, reservas } \\
\text { naturais }\end{array}$ & 2 & 1 & & 1 & 4 \\
\hline $\begin{array}{l}\text { g. } \text { Pratica esportes ou } \\
\text { fazer exercícios }\end{array}$ & 2 & 1 & & 1 & 4 \\
\hline $\begin{array}{l}\text { h. Vai ao estádio de } \\
\text { futebol }\end{array}$ & & & & 4 & 4 \\
\hline $\begin{array}{l}\text { i. Vai à lgreja } \\
\text { F. }\end{array}$ & 3 & 1 & & & 4 \\
\hline
\end{tabular}

FONTE: VERISSIMO, J. 2005.

Entre os conselheiros de Cidade Tiradentes a principal atividade de lazer apareceu como sendo as festas. A igreja, a exemplo dos demais Conselhos, permaneceu freqüente para a vida social destes conselheiros. 
TABELA 19.1.2: AVALIAÇÃO DA VIDA SOCIAL DOS CONSELHEIROS DE CIDADE TIRADENTES.

\begin{tabular}{|c|c|c|c|c|c|}
\hline \multicolumn{6}{|c|}{$\begin{array}{c}\text { Vou apresentar algumas atividades que você pode fazer durante o seu } \\
\text { tempo livre ou de lazer. Eu gostaria de saber se você }\end{array}$} \\
\hline Atividade & Sempre & $\begin{array}{c}\text { Às } \\
\text { vezes }\end{array}$ & Raramente & Nunca & Total \\
\hline $\begin{array}{l}\text { a. Visita amigos e } \\
\text { parentes }\end{array}$ & 2 & 1 & 1 & & 4 \\
\hline $\begin{array}{l}\text { b. Vai a bares ou } \\
\text { restaurantes }\end{array}$ & 1 & 1 & 1 & 1 & 4 \\
\hline c. Vai ao cinema & & 1 & 1 & 2 & 4 \\
\hline $\begin{array}{l}\text { d. Vai a festas (de } \\
\text { amigos, parentes, de } \\
\text { igreja, de associações, } \\
\text { etc) }\end{array}$ & 4 & & & & 4 \\
\hline e. Passeia em praças & 2 & 1 & & 1 & 4 \\
\hline $\begin{array}{l}\text { f. Passeia em } \\
\text { cachoeiras, reservas } \\
\text { naturais }\end{array}$ & & & 2 & 2 & 4 \\
\hline $\begin{array}{l}\text { g. Pratica esportes ou } \\
\text { fazer exercícios }\end{array}$ & 2 & 2 & & & 4 \\
\hline $\begin{array}{l}\text { h. Vai ao estádio de } \\
\text { futebol }\end{array}$ & & & & 4 & 4 \\
\hline i. Vai à Igreja & 2 & 1 & 1 & & 4 \\
\hline
\end{tabular}

FONTE: VERÍSSIMO, J. 2005.

Igreja, festas e visita à casa de amigos e parentes, corroborando as práticas de lazer dos conselheiros dos demais Conselhos, mostraram-se as atividades sociais mais praticadas pelos conselheiros do Conselho de Parelheiros, o qual detém, por sua vez, o melhor índice de institucionalização: 0,84. 
TABELA 19.1.3: AVALIAÇÃO DA VIDA SOCIAL DOS CONSELHEIROS DE PARELHEIROS.

\begin{tabular}{|c|c|c|c|c|c|}
\hline \multicolumn{6}{|c|}{$\begin{array}{c}\text { Vou apresentar algumas atividades que você pode fazer durante o seu } \\
\text { tempo livre ou de lazer. Eu gostaria de saber se você }\end{array}$} \\
\hline Atividade & Sempre & $\begin{array}{c}\text { Às } \\
\text { vezes }\end{array}$ & Raramente & Nunca & Total \\
\hline $\begin{array}{l}\text { a. Visita amigos e } \\
\text { parentes }\end{array}$ & 2 & 2 & & & 4 \\
\hline $\begin{array}{l}\text { b. Vai a bares ou } \\
\text { restaurantes }\end{array}$ & & & 1 & 3 & 4 \\
\hline c. Vai ao cinema & & & 2 & 2 & 4 \\
\hline $\begin{array}{l}\text { d. Vai a festas (de } \\
\text { amigos, parentes, de } \\
\text { igreja, de associações, } \\
\text { etc) }\end{array}$ & 3 & & 1 & & 4 \\
\hline e. Passeia em praças & & & 1 & 3 & 4 \\
\hline $\begin{array}{l}\text { f. Passeia em } \\
\text { cachoeiras, reservas } \\
\text { naturais }\end{array}$ & & 2 & & 2 & 4 \\
\hline $\begin{array}{l}\text { g. Pratica esportes ou } \\
\text { fazer exercícios }\end{array}$ & 1 & 1 & & 2 & 4 \\
\hline $\begin{array}{l}\text { h. Vai ao estádio de } \\
\text { futebol }\end{array}$ & & & 1 & 3 & 4 \\
\hline i. Vai à lgreja & 3 & 1 & & & 4 \\
\hline
\end{tabular}

FONTE: VERÍSSIMO, J. 2005.

Entre os conselheiros que iniciaram sua vida associativa período anterior e/ou até 1980 as festas nas casas de amigos, parentes igrejas ou associações, e a ida à igreja apareceram como as duas formas mais freqüentes de lazer. Estas se mostraram ser a prática da quase totalidade dos conselheiros no primeiro caso (4), e de todos eles no caso da igreja (5). 
TABELA 19.2: AVALIAÇÃO DA VIDA SOCIAL DOS CONSELHEIROS QUE INICIARAM SUA PARTICIPAÇÃO PERÍODO ANTERIOR E/OU ATÉ 1980.

\begin{tabular}{|l|c|c|c|c|c|}
\hline \multicolumn{6}{|c|}{$\begin{array}{c}\text { Vou apresentar algumas atividades que você pode fazer durante o seu } \\
\text { tempo livre ou de lazer. Eu gostaria de saber se você }\end{array}$} \\
\hline Atividade & Sempre & $\begin{array}{c}\text { Às } \\
\text { vezes }\end{array}$ & Raramente & Nunca & Total \\
\hline $\begin{array}{l}\text { a. Visita amigos e } \\
\text { parentes }\end{array}$ & 2 & 2 & 1 & & 5 \\
\hline $\begin{array}{l}\text { b. Vai a bares ou } \\
\text { restaurantes }\end{array}$ & & & 3 & 2 & 5 \\
\hline c. Vai ao cinema & & & 1 & 4 & 5 \\
\hline $\begin{array}{l}\text { d. Vai a festas (de } \\
\text { amigos, parentes, de } \\
\text { igreja, de associações, } \\
\text { etc) }\end{array}$ & 4 & & 1 & & 5 \\
\hline e. Passeia em praças & 1 & & 1 & 3 & 5 \\
\hline $\begin{array}{l}\text { f. Passeia em } \\
\text { cachoeiras, reservas } \\
\text { naturais }\end{array}$ & 1 & 1 & 1 & 2 & 5 \\
\hline $\begin{array}{l}\text { g. Pratica esportes ou } \\
\text { fazer exercícios }\end{array}$ & 1 & 2 & & 2 & 5 \\
\hline $\begin{array}{l}\text { h. Vai ao estádio de } \\
\text { futebol }\end{array}$ & 1 & & & 4 & 5 \\
\hline i. Vai à lgreja & 5 & & & 5 \\
\hline
\end{tabular}

FONTE: VERÍSSIMO, J. 2005.

As festas apareceram como a principal prática social dos conselheiros do grupo que iniciou a participar entre 1981 e 1992. Para estes conselheiros a ida à igreja já não foi unânime, mas ainda apareceu com muita força (04). A novidade é que dois destes conselheiros afirmaram sempre praticar esportes como forma de lazer, e três deles disseram passear em cachoeiras e reservas naturais às vezes. 
TABELA 19.2.1: AVALIAÇÃO DA VIDA SOCIAL DOS CONSELHEIROS QUE INICIARAM SUA PARTICIPAÇÃO ENTRE 1981 E 1992.

\begin{tabular}{|l|c|c|c|c|c|}
\hline \multicolumn{6}{|c|}{$\begin{array}{l}\text { Vou apresentar algumas atividades que você pode fazer durante o } \\
\text { seu tempo livre ou de lazer. Eu gostaria de saber se você }\end{array}$} \\
\hline Atividade & Sempre & $\begin{array}{c}\text { Às } \\
\text { vezes }\end{array}$ & Raramente & Nunca & Total \\
\hline $\begin{array}{l}\text { a. Visita amigos e } \\
\text { parentes }\end{array}$ & & 3 & 3 & & 6 \\
\hline $\begin{array}{l}\text { b. Vai a bares ou } \\
\text { restaurantes }\end{array}$ & 1 & 1 & 2 & 2 & 6 \\
\hline c. Vai ao cinema & & 2 & 3 & 1 & 6 \\
\hline $\begin{array}{l}\text { d. Vai a festas (de } \\
\text { amigos, parentes, } \\
\text { de igreja, de } \\
\text { associaçóes, etc) }\end{array}$ & 4 & 2 & & & 6 \\
\hline $\begin{array}{l}\text { e. Passeia em } \\
\text { praças }\end{array}$ & & 1 & 4 & 1 & 6 \\
\hline $\begin{array}{l}\text { f. Passeia em } \\
\text { cachoeiras, } \\
\text { reservas naturais }\end{array}$ & & 3 & 2 & 1 & 6 \\
\hline $\begin{array}{l}\text { g. Pratica } \\
\text { esportes ou fazer } \\
\text { exercícios }\end{array}$ & 2 & & 2 & 2 & 6 \\
\hline $\begin{array}{l}\text { h. Vai ao estádio } \\
\text { de futebol }\end{array}$ & & & 2 & 4 & 6 \\
\hline $\begin{array}{l}\text { i. Vai à lgreja } \\
\text { FONTE. VERissIMO, }\end{array}$ & 4 & 1 & 1 & & 6 \\
\hline
\end{tabular}

FONTE: VERISSIMO, J. 2005.

Curioso é o fato de que ao serem agregados por tempo de participação, os conselheiros que a iniciaram depois de 2001 não referiram a igreja como modo freqüente de lazer. Neste grupo, a prática de esporte apareceu como prática de lazer mais utilizada, e a visita a amigos e parentes também perdeu a relevância. As festas e a ida a bares ou restaurantes, contudo, permaneceram relacionadas como práticas comuns de lazer. 
TABELA 19.2.2: AVALIAÇÃO DA VIDA SOCIAL DOS CONSELHEIROS QUE INICIARAM SUA PARTICIPAÇÃO DEPOIS DE 2001.

\begin{tabular}{|c|c|c|c|c|c|}
\hline \multicolumn{6}{|c|}{$\begin{array}{c}\text { Vou apresentar algumas atividades que você pode fazer durante o } \\
\text { seu tempo livre ou de lazer. Eu gostaria de saber se você }\end{array}$} \\
\hline Atividade & Sempre & Às vezes & Raramente & Nunca & Total \\
\hline $\begin{array}{l}\text { a. Visita amigos e } \\
\text { parentes }\end{array}$ & & 2 & 3 & & 5 \\
\hline $\begin{array}{l}\text { b. Vai a bares ou } \\
\text { restaurantes }\end{array}$ & 1 & 3 & & 1 & 5 \\
\hline c. Vai ao cinema & & & 3 & 2 & 5 \\
\hline $\begin{array}{l}\text { d. Vai a festas } \\
\text { (de amigos, } \\
\text { parentes, de } \\
\text { igreja, de } \\
\text { associações, etc) }\end{array}$ & 2 & 3 & & & 5 \\
\hline $\begin{array}{l}\text { e. Passeia em } \\
\text { praças }\end{array}$ & 2 & 1 & & 2 & 5 \\
\hline $\begin{array}{l}\text { f. Passeia em } \\
\text { cachoeiras, } \\
\text { reservas naturais }\end{array}$ & & 1 & & 4 & 5 \\
\hline $\begin{array}{l}\text { g. Pratica } \\
\text { esportes ou fazer } \\
\text { exercícios }\end{array}$ & 3 & & & 2 & 5 \\
\hline $\begin{array}{l}\text { h. Vai ao estádio } \\
\text { de futebol }\end{array}$ & & & & 5 & 5 \\
\hline i. Vai à Igreja & 1 & 2 & 1 & 1 & 5 \\
\hline
\end{tabular}

FONTE: VERÍSSIMO, J. 2005.

\section{g) Confiança Generalizada, na Polícia e no sistema médico}

A maioria dos conselheiros, 12 dos 16 entrevistados, concordou em parte com a afirmação de que a maioria das pessoas do bairro são confiáveis. Apenas um conselheiro do Conselho com o mais baixo indicador de institucionalidade, 0,42, (Vila Prudente) concordou totalmente, e dois conselheiros em Perus (Conselho que detém o segundo mais elevado indicador de institucionalidade: 0,70 ) discordaram em parte. 
TABELA 20: CONFIANÇA NOS MORADORES DO BAIRRO, POR CONSELHO DE QUE FAZ PARTE.

\begin{tabular}{|l|c|c|c|c|}
\hline \multicolumn{5}{|c|}{ Pode-se confiar na maioria das pessoas deste bairro. Você? } \\
\hline $\begin{array}{l}\text { Conselho de } \\
\text { que faz parte }\end{array}$ & $\begin{array}{c}\text { concorda } \\
\text { totalmente }\end{array}$ & $\begin{array}{c}\text { concorda } \\
\text { em parte }\end{array}$ & $\begin{array}{c}\text { discorda } \\
\text { em parte }\end{array}$ & Total \\
\hline VI Prudente & 1 & 3 & & 4 \\
\hline Perus & & 2 & 2 & 4 \\
\hline Cid Tiradentes & & 3 & 1 & 4 \\
\hline Parelheiros & & 4 & & 4 \\
\hline Total & 1 & 12 & 3 & 16 \\
\hline
\end{tabular}

FONTE: VERISSIMO, J. 2005.

Separando-se os conselheiros por período de início de participação, percebe-se que o grupo "entre 1981 e 1992" foi o que mais teve conselheiros que disseram discordar da afirmação (02), mas também foi o único grupo no qual houve um conselheiro que concordou totalmente com ela. O grupo "período anterior e/ou até 1980" foi unânime em afirmar que concorda parcialmente com a afirmativa.

\section{TABELA 20.1: CONFIANÇA NOS MORADORES DO BAIRRO, POR PERÍODO DE INÍCIO DE PARTICIPAÇÃO.}

\begin{tabular}{|l|c|c|c|c|}
\hline \multicolumn{5}{|c|}{ Pode-se confiar na maioria das pessoas deste bairro. Você? } \\
\hline Período & $\begin{array}{c}\text { concorda } \\
\text { totalmente }\end{array}$ & $\begin{array}{c}\text { concorda em } \\
\text { parte }\end{array}$ & $\begin{array}{c}\text { discorda em } \\
\text { parte }\end{array}$ & Total \\
\hline $\begin{array}{l}\text { período anterior } \\
\text { e/ou até 1980 }\end{array}$ & & 5 & & 5 \\
\hline $\begin{array}{l}\text { entre 1981 e } \\
1992\end{array}$ & 1 & 3 & 2 & 6 \\
\hline depois de 2001 & 1 & 4 & 1 & 5 \\
\hline Total & 1 & 12 & 3 & 16 \\
\hline
\end{tabular}

FONTE: VERISSIMO, J. 2005. 
Indagados se julgam os vizinhos pessoas prestativas, metade dos conselheiros concordou em parte (08). Três deles concordaram totalmente, e o mesmo número discordou em parte. A novidade em relação às tabelas anteriores foi a de que dois dos 16 conselheiros entrevistados disseram discordar totalmente da afirmativa. Estes conselheiros que discordaram encontram-se um em Perus, e o outro em Parelheiros - ambos com os mais elevados índices de institucionalidade: 0,70 e 0,84 respectivamente.

TABELA 21: AVALIAÇÃO DA SOLICITUDE DOS VIZINHOS, POR CONSELHO DE QUE FAZ PARTE.

\begin{tabular}{|l|c|c|c|c|c|}
\hline \multicolumn{5}{|c|}{ Os vizinhos neste bairro são pessoas prestativas. Você? } \\
\hline $\begin{array}{l}\text { Conselho de } \\
\text { que faz parte }\end{array}$ & $\begin{array}{c}\text { concorda } \\
\text { totalmente }\end{array}$ & $\begin{array}{c}\text { concorda em } \\
\text { parte }\end{array}$ & $\begin{array}{c}\text { discorda } \\
\text { em parte }\end{array}$ & $\begin{array}{c}\text { discorda } \\
\text { totalmente }\end{array}$ & Total \\
\hline VI Prudente & 1 & 3 & & & 4 \\
\hline Perus & 1 & & 2 & 1 & 4 \\
\hline $\begin{array}{l}\text { Cid } \\
\text { Tiradentes }\end{array}$ & 1 & 3 & 1 & & 4 \\
\hline Parelheiros & 3 & 8 & 3 & 2 & 16 \\
\hline Total & 2 & 2 & & 1 & 4 \\
\hline
\end{tabular}

FONTE: VERISSIMO, J. 2005.

As opiniões foram bastante diversas quando analisadas por período de início de participação. Na tabela abaixo se pode ver que o grupo "depois de 2001" apareceu com o maior número de conselheiros que menos concordou com a afirmativa da solicitude dos vizinhos: três conselheiros concordaram em parte, um deles discordou em parte e outro discordou totalmente. 
TABELA 21.1: AVALIAÇÃO DA SOLICITUDE DOS VIZINHOS, POR PERÍODO DE INÍCIO DE PARTICIPAÇÃO.

\begin{tabular}{|l|c|c|c|c|c|}
\hline \multicolumn{5}{|c|}{ Os vizinhos neste bairro são pessoas prestativas. Você? } \\
\hline Período & $\begin{array}{c}\text { concorda } \\
\text { totalmente }\end{array}$ & $\begin{array}{c}\text { concorda } \\
\text { em parte }\end{array}$ & $\begin{array}{c}\text { discorda em } \\
\text { parte }\end{array}$ & $\begin{array}{c}\text { discorda } \\
\text { totalmente }\end{array}$ & Total \\
\hline $\begin{array}{l}\text { período anterior } \\
\text { elou até 1980 }\end{array}$ & 2 & 2 & & 1 & 5 \\
\hline $\begin{array}{l}\text { entre 1981 e } \\
1992\end{array}$ & 1 & 3 & 2 & & 6 \\
\hline depois de 2001 & & 3 & 1 & 1 & 5 \\
\hline Total & 3 & 8 & 3 & 2 & 16 \\
\hline
\end{tabular}

FONTE: VERISSIMO, J. 2005.

Questionados sobre a confiança na maioria das pessoas, a maioria absoluta dos conselheiros, 13 deles, afirmou que cuidado nunca é demais, quando se perguntou: de maneira geral, você diria que podemos confiar na maioria das pessoas ou você acha que cuidado nunca é demais?

Os conselheiros de Cidade Tiradentes foram unânimes ao responderem que cuidado nunca é demais. Dentre os conselheiros dos outros três Conselhos (Vila Prudente, Perus e Parelheiros) houve a freqüência de um conselheiro em cada Conselho que respondeu que se pode confiar na maioria das pessoas.

TABELA 22: AVALIAÇÃO DE CONFIANÇA GENERALIZADA, POR CONSELHO DE QUE FAZ PARTE.

\begin{tabular}{|l|c|c|c|}
\hline \multicolumn{1}{|c|}{$\begin{array}{c}\text { De maneira geral, você diria que podemos confiar na maioria } \\
\text { das pessoas, ou você acha que cuidado nunca é demais? }\end{array}$} \\
\hline $\begin{array}{l}\text { Conselho de } \\
\text { que faz parte }\end{array}$ & $\begin{array}{c}\text { podemos confiar na } \\
\text { maioria das pessoas }\end{array}$ & $\begin{array}{c}\text { cuidado nunca e } \\
\text { demais }\end{array}$ & Total \\
\hline VI Prudente & 1 & 3 & 4 \\
\hline Perus & 1 & 3 & 4 \\
\hline $\begin{array}{l}\text { Cid } \\
\text { Tiradentes }\end{array}$ & & 4 & 4 \\
\hline Parelheiros & 1 & 3 & 4 \\
\hline Total & 3 & 13 & 16 \\
\hline
\end{tabular}

FONTE: VERISSIMO, J. 2005. 
Os três conselheiros que disseram que se pode confiar na maioria das pessoas iniciaram suas vidas associativas no período anterior e/ou até 1980. Os conselheiros que começaram a participar entre 1981 e 1992 e depois de 2001, entretanto, mostraram-se coesos ao afirmar que cuidado nunca é demais.

\section{TABELA 22.1: AVALIAÇÃO DE CONFIANÇA GENERALIZADA, POR PERÍODO DE INÍCIO DE PARTICIPAÇÃO.}

\begin{tabular}{|l|c|c|c|}
\hline \multicolumn{4}{|c|}{$\begin{array}{c}\text { De maneira geral, você diria que podemos confiar na maioria } \\
\text { das pessoas, ou você acha que cuidado nunca é demais? }\end{array}$} \\
\hline Período & $\begin{array}{l}\text { podemos confiar na } \\
\text { maioria das pessoas }\end{array}$ & $\begin{array}{c}\text { cuidado } \\
\text { nunca e } \\
\text { demais }\end{array}$ & Total \\
\hline $\begin{array}{l}\text { período anterior } \\
\text { e/ou até 1980 }\end{array}$ & 3 & 2 & 5 \\
\hline $\begin{array}{l}\text { entre 1981 e } \\
1992\end{array}$ & & 6 & 6 \\
\hline depois de 2001 & & 5 & 5 \\
\hline Total & 3 & 13 & 16 \\
\hline
\end{tabular}

FONTE: VERISSIMO, J. 2005.

Mediu-se entre os conselheiros sua confiança na polícia e no sistema de atenção médica. Os dados que compuseram as respostas se seguem nas tabelas.

TABELA 23: CONFIANÇA NA ATUAÇÃO DA PM, POR CONSELHO DE QUE FAZ PARTE.

\begin{tabular}{|l|c|c|c|c|}
\hline \multicolumn{5}{|c|}{ Pensando na atuação da Polícia Militar (PM) em sua vizinhança, você } \\
\hline $\begin{array}{l}\text { Conselho de que } \\
\text { faz parte }\end{array}$ & confia & confia pouco & não confia & Total \\
\hline Vl. Prudente & & 3 & 1 & 4 \\
\hline Perus & 1 & 2 & 1 & 4 \\
\hline Cid. Tiradentes & 1 & 1 & 2 & 4 \\
\hline Parelheiros & 2 & 2 & & 4 \\
\hline Total & 4 & 8 & 4 & 16 \\
\hline
\end{tabular}

FONTE: VERISSIMO, J. 2005 
Como se vê na tabela acima, 12 conselheiros disseram confiar pouco ou não confiar na Polícia Militar (08 e 04 conselheiros, respectivamente). Os conselheiros do Conselho de Parelheiros (o mais institucionalizado, segundo o índice utilizado) foram os que mais afirmaram confiar na PM: dois deles disseram confiar na atuação da polícia e dois deles confiar pouco.

Vê-se na tabela abaixo que os dados não sofreram grandes alterações se agregados por período de início de participação. O grupo que iniciou sua participação no período anterior e/ou até 1980 teve a maior freqüência de conselheiros que disseram confiar na PM (2), e o grupo que iniciou entre 1981 e 1992 apresentou o maior número dos que afirmaram não confiar.

\section{TABELA 23.1: CONFIANÇA NA ATUAÇÃO DA PM, POR PERÍODO DE INÍCIO DE PARTICIPAÇÃO.}

\begin{tabular}{|l|c|c|c|c|}
\hline \multicolumn{5}{|c|}{ Pensando na atuação da Polícia Militar (PM) em sua vizinhança, você } \\
\hline Período & confia & confia pouco & não confia & Total \\
\hline $\begin{array}{l}\text { período anterior e/ou } \\
\text { até 1980 }\end{array}$ & 2 & 2 & 1 & 5 \\
\hline entre 1981 e 1992 & 1 & 3 & 2 & 6 \\
\hline depois de 2001 & 1 & 3 & 1 & 5 \\
\hline Total & 4 & 8 & 4 & 16 \\
\hline
\end{tabular}

FONTE: VERÍSSIMO, J. 2005

Perguntados sobre a eficiência da polícia para solucionar os problemas de segurança no bairro, a maioria dos conselheiros (11) avaliou a atuação da PM como pouco eficiente. Em Parelheiros, metade dos conselheiros entrevistados (2) disse que a atuação da polícia é eficiente. Já em Vila Prudente (o Conselho com menor índice de institucionalidade), todos os ouvidos para nossa pesquisa disseram que a polícia é pouco eficiente. 
TABELA 24: AVALIAÇÃO DA EFICIÊNCIA DA PM, POR CONSELHO DE QUE FAZ PARTE.

\begin{tabular}{|l|c|c|c|c|}
\hline \multicolumn{5}{|c|}{ Pensando na resolução de problemas de violência em sua vizinhança, } \\
você diria que a PM é ...
\end{tabular}

FONTE: VERISSIMO, J. 2005

Analisados agregados por período de início de participação, os dados não apresentaram grandes alterações. Olhando-se a tabela abaixo, nota-se que o grupo "período anterior e/ou até 1980" teve o maior número de conselheiros que julgou a atuação da PM eficiente (02).

\section{TABELA 24.1: AVALIAÇÃO DA EFICÊNCIA DA PM, POR PERÍODO DE INÍCIO DE PARTICIPAÇÃO..}

\begin{tabular}{|l|c|c|c|c|}
\hline \multicolumn{5}{|l|}{ Pensando na resolução de problemas de violência em sua vizinhança, você } \\
diria que a PM é ... \\
\hline Período & eficiente & pouco eficiente & nada eficiente & Total \\
\hline $\begin{array}{l}\text { período anterior } \\
\text { e/ou até 1980 }\end{array}$ & 2 & 3 & & 5 \\
\hline entre 1981 e 1992 & 1 & 5 & & 6 \\
\hline depois de 2001 & 1 & 3 & 1 & 5 \\
\hline Total & 4 & 11 & 1 & 16 \\
\hline
\end{tabular}

FONTE: VERISSIMO, J. 2005

Sobre o sistema de saúde, questionados acerca de sua segurança em relação ao atendimento médico em sua vizinhança, 10 dos 16 conselheiros se disseram sentir inseguros, e 03 deles se declararam muito inseguros. Vila Prudente, Cidade Tiradentes e Parelheiros apresentaram cada um a freqüência de um conselheiro que se disse sentir seguro com o atendimento à saúde. Perus, em detrimento a ser o detentor do segundo mais elevado índice de institucionalidade $(0,70)$ foi o 
Conselho no qual os conselheiros afirmaram se sentir mais inseguros, tendo dois deles declarado se sentirem inseguros e os outros dois muito inseguros.

\section{TABELA 25: CONFIANÇA NO ATENDIMENTO À SAÚDE, POR CONSELHO DE QUE FAZ PARTE.}

\begin{tabular}{|l|c|c|c|c|}
\hline \multicolumn{6}{|c|}{ Como você se sente ao precisar de atendimento à saúde na } \\
sua vizinhança?
\end{tabular}

FONTE: VERISSIMO, J. 2005.

Separados por período de início de participação, vê-se, na tabela abaixo, que o grupo "período anterior e/ou até 1980" apresentou dois conselheiros que julgaram sentir-se seguros ao necessitar de atendimento médico na região onde moram. Já o grupo que iniciou sua participação em 2001 mostrou-se mais inseguro: 02 conselheiros declararam sentirem-se inseguros e 03 muito inseguros.

\section{TABELA 25.1: CONFIANÇA NO ATENDIMENTO À SAÚDE, POR PERÍODO DE INÍCIO DE PARTICIPAÇÃO..}

\begin{tabular}{|l|c|c|c|c|}
\hline \multicolumn{6}{|l|}{ Como você se sente ao precisar de atendimento à saúde na sua } \\
vizinhança?
\end{tabular}

FONTE: VERISSIMO, J. 2005

Já quando os conselheiros avaliaram a atuação dos médicos, nove dentre os 16 julgaram que confiam na atuação daqueles. Em Parelheiros foi onde a confiança nos médicos mostrou-se maior entre os conselheiros entrevistados, 03 
responderam confiar na atuação médica na região. Perus e Cidade Tiradentes, contudo, apresentaram a maior freqüência dos conselheiros que "confiam pouco" na atuação dos médicos: 02 conselheiros em cada um destes Conselhos.

TABELA 26: CONFIANÇA NOS MÉDICOS, POR CONSELHO DE QUE FAZ PARTE.

\begin{tabular}{|l|c|c|c|c|}
\hline \multicolumn{5}{|c|}{$\begin{array}{c}\text { Pensando na atuação dos médicos dos postos de saúde e } \\
\text { hospitais em sua vizinhança, você }\end{array}$} \\
\hline $\begin{array}{l}\text { Conselho de } \\
\text { que faz parte }\end{array}$ & confia muito & confia & confia pouco & Total \\
\hline Vl. Prudente & 1 & 2 & 1 & 4 \\
\hline Perus & & 2 & 2 & 4 \\
\hline Cid. Tiradentes & & 2 & 2 & 4 \\
\hline Parelheiros & & 3 & 1 & 4 \\
\hline Total & 1 & 9 & 6 & 16 \\
\hline
\end{tabular}

FONTE: VERISSIMO, J. 2005

Agregados por período de início de participação, o grupo dos conselheiros que iniciou sua participação no período anterior e/ou até 1980 evidenciou-se como o mais confiante na atuação dos médicos: todos os conselheiros deste grupo disseram confiar. Já o grupo que iniciou sua participação depois de 2001 foi o que declarou menos confiança: três dos cinco conselheiros deste grupo disseram confiar pouco na atuação dos médicos nos postos de saúde e hospitais da região.

TABELA 26.1: CONFIANÇA NOS MÉDICOS, POR PERÍODO DE INÍCIO DE PARTICIPAÇÃO.

\begin{tabular}{|l|c|c|c|c|}
\hline \multicolumn{5}{|c|}{$\begin{array}{c}\text { Pensando na atuação dos médicos dos postos de saúde e } \\
\text { hospitais em sua vizinhança, você }\end{array}$} \\
\hline $\begin{array}{l}\text { Período } \\
\text { período anterior } \\
\text { e/ou até 1980 }\end{array}$ & confia muito & confia & confia pouco & Total \\
\hline entre 1981 e 1992 & & 5 & & 5 \\
\hline depois de 2001 & 1 & 3 & 3 & 6 \\
\hline Total & 1 & 9 & 3 & 5 \\
\hline
\end{tabular}

FONTE: VERISSIMO, J. 2005 
Convidados a avaliarem a eficiência do sistema de saúde, 10 conselheiros julgaram-no pouco eficiente. Perus e Cidade Tiradentes $(0,70$ e 0,61 ponto no índice de institucionalidade, respectivamente) apresentaram, cada qual, três conselheiros que julgaram o sistema pouco eficiente. Já Vila Prudente $(0,42$ ponto no índice) e Parelheiros ( 0,84 ponto) tiveram os conselheiros divididos: 02 deles, em cada Conselho, avaliaram que o sistema é eficiente, e outros 02 que ele é pouco eficiente.

TABELA 27: AVALIAÇÃO DA EFICIÊNCIA DO SISTEMA DE SAÚDE, POR CONSELHO DE QUE FAZ PARTE.

\begin{tabular}{|l|c|c|c|}
\hline \multicolumn{4}{|c|}{$\begin{array}{c}\text { Pensando na resolução de seus problemas de saúde } \\
\text { em sua vizinhança, você diria que as unidades de } \\
\text { saúde são ... }\end{array}$} \\
\hline $\begin{array}{l}\text { Conselho de } \\
\text { que faz parte }\end{array}$ & eficiente & pouco eficiente & Total \\
\hline VI. Prudente & 2 & 2 & 4 \\
\hline Perus & 1 & 3 & 4 \\
\hline Cid. Tiradentes & 1 & 3 & 4 \\
\hline Parelheiros & 2 & 2 & 4 \\
\hline Total & 6 & 10 & 16 \\
\hline
\end{tabular}

FONTE: VERISSIMO, J. 2005

Agregados por período de início de participação, observou-se que o primeiro grupo da tabela 27.1, "período anterior e/ou até 1980", foi o que apresentou a maior freqüência de conselheiros que avaliou o sistema como sendo eficiente. Já 05 dos 06 conselheiros do grupo "entre 1981 e 1992" analisaram o sistema de saúde como pouco eficiente.

TABELA 27.1: AVALIAÇÃO DA EFICIÊNCIA DO SISTEMA DE SAÚDE, POR PERÍODO DE INÍCIO DE PARTICIPAÇÃO..

\begin{tabular}{|l|c|c|c|}
\hline \multicolumn{3}{|c|}{$\begin{array}{c}\text { Pensando na resolução de seus problemas de saúde em sua } \\
\text { vizinhança, você diria que as unidades de saúde são ... }\end{array}$} \\
\hline Período & eficiente & pouco eficiente & Total \\
\hline período anterior e/ou até 1980 & 3 & 2 & 5 \\
\hline entre 1981 e 1992 & 1 & 5 & 6 \\
\hline depois de 2001 & 2 & 3 & 5 \\
\hline Total & 6 & 10 & 16 \\
\hline
\end{tabular}

FONTE: VERISSIMO, J. 2005 


\section{h) Avaliação dos Conselhos Gestores de Saúde}

Ao opinarem sobre as possibilidades geradas pela implementação dos Conselhos Gestores de Saúde, os conselheiros julgaram que, em geral, as oportunidades de decisão sobre as obras da saúde e a prestação de contas das Subprefeituras aumentaram (10 e 09 conselheiros, respectivamente). Contudo, 07 deles acharam que a atenção dada às demandas da população por parte das Subprefeituras permaneceu a mesma de antes da implementação dos Conselhos. Analisando a questão do poder dos vereadores, 05 conselheiros disseram ter aumentado a influência daqueles sobre as questões locais de saúde. Os conselheiros que viram menos possibilidades geradas pelos Conselhos foram os de Perus, no qual três conselheiros julgaram que a prestação de contas da Subprefeitura diminuiu com o advento dos Conselhos, e que a atenção às demandas da população permaneceu a mesma de antes da instauração destes fóruns. Lembro que este Conselho, de Perus, obteve a segunda maior posição no índice institucional: 0,70.

\section{TABELA 28: AVALIAÇÃO DOS CONSELHEIROS DE VILA PRUDENTE E PERUS ACERCA DAS OPORTUNIDADES GERADAS PELA IMPLEMENTAÇÃO DOS CONSELHOS.}

\begin{tabular}{|c|c|c|c|c|c|c|c|c|}
\hline \multicolumn{9}{|c|}{$\begin{array}{c}\text { Na sua opinião, com os Conselhos de Saúde ... na sua região aumentam, diminuem ou continuam } \\
\text { iguais?* }\end{array}$} \\
\hline $\begin{array}{l}\text { Conselho de } \\
\text { que faz parte }\end{array}$ & \multicolumn{4}{|c|}{ Vila Prudente } & \multicolumn{4}{|c|}{ Perus } \\
\hline Oportunidades & $\begin{array}{l}\text { decidir } \\
\text { sobre } \\
\text { as } \\
\text { obras } \\
\text { de } \\
\text { saúde }\end{array}$ & $\begin{array}{c}\text { prestação } \\
\text { de contas } \\
\text { das Sub }\end{array}$ & $\begin{array}{c}\text { atenção } \\
\text { às } \\
\text { demandas } \\
\text { da } \\
\text { população }\end{array}$ & $\begin{array}{c}\text { poder dos } \\
\text { Vereadores }\end{array}$ & \begin{tabular}{|l} 
decidir \\
sobre \\
as \\
obras \\
de \\
saúde
\end{tabular} & $\begin{array}{c}\text { prestação } \\
\text { de contas } \\
\text { das Sub }\end{array}$ & $\begin{array}{c}\text { atenção } \\
\text { às } \\
\text { demandas } \\
\text { da } \\
\text { população }\end{array}$ & $\begin{array}{l}\text { poder dos } \\
\text { Vereadores }\end{array}$ \\
\hline aumentou & 4 & 3 & 2 & & & & & 2 \\
\hline diminuiu & & & & & 2 & 3 & & 1 \\
\hline continua igual & & 1 & 2 & 4 & 2 & 1 & 4 & 1 \\
\hline
\end{tabular}

FONTE: VERÍSSIMO, J. 2005

${ }^{*}$ Respostas múltiplas 


\section{TABELA 28.1: AVALIAÇÃO DOS CONSELHEIROS DE CIDADE TIRADENTES E PARELHEIROS ACERCA DAS OPORTUNIDADES GERADAS PELA IMPLEMENTAÇÃO DOS CONSELHOS.}

\begin{tabular}{|l|c|c|c|c||c|c|c||}
\hline \multicolumn{2}{|c|}{ Na sua opinião, com os Conselhos de Saúde ... na sua região aumentam, diminuem ou continuam } \\
iguais?*
\end{tabular}

FONTE: VERÍSSIMO, J. 2005

* Respostas múltiplas

Ao se analisar os dados agregados por período de início de participação, nota-se que o grupo mais otimista em suas avaliações acerca das possibilidades geradas pelo aparecimento dos Conselhos foi o que iniciou sua participação entre 1981 e 1992. Todos os conselheiros deste grupo julgaram ter aumentado o poder de decisão popular sobre as obras da saúde depois da implementação dos Conselhos; 04 conselheiros avaliaram que a prestação de contas das Subprefeituras aumentou e três acharam que aumentou a atenção dada às demandas da população. Em contraste, o grupo que iniciou suas atividades participativas depois de 2001 foi o mais cético em relação à implementação dos Conselhos: dois conselheiros julgaram que as possibilidades da população decidir sobre as obras de saúde diminuíram, e dois que ela permaneceu inalterada; três deles também disseram que a prestação de contas da Subprefeitura diminuiu ou continua igual; quatro dos cinco conselheiros deste grupo afirmaram que a atenção às demandas da população continuou igual a antes dos Conselhos, e três deles disseram que o poder dos vereadores permaneceu igual, e dois que este poder aumentou. 


\section{TABELA 28.2: OPORTUNIDADES GERADAS PELA IMPLEMENTAÇÃO DOS CONSELHOS, POR PERÍODO DE INÍCIO DE PARTICIPAÇÃO.}

\begin{tabular}{|c|c|c|c||c|c|c||c|c|c|}
\hline \multicolumn{2}{|c|}{ Na sua opinião, com os Conselhos de Saúde ... na sua região aumentam, diminuem ou } \\
continuam iguais?*
\end{tabular}

FONTE: VERÍSSIMO, J. 2005

* Respostas múltiplas

Perguntou-se aos conselheiros se eles julgavam que a organização dos Conselhos tem sido democrática. Metade deles, 08, julgou que sim, e 02 deles disseram ser muito democrática. Os conselheiros que julgaram a organização de seu Conselho mais democrática foram os de Vila Prudente (Conselho que detém o menor índice institucional): 01 conselheiro disse ser muito democrática e 02 disseram ser democrática. 02 conselheiros em Perus e 02 em Parelheiros afirmaram que a organização de seus Conselhos tem sido pouco democrática.

TABELA 29: GRAU DE DEMOCRATIZAÇÃO NA ORGANIZAÇÃO DOS CONSELHOS, POR CONSELHO DE QUE FAZ PARTE.

\begin{tabular}{|l|c|c|c|c|}
\hline \multicolumn{5}{|c|}{ Na sua opinião, a organização do CGS tem sido: } \\
\hline Conselho & $\begin{array}{c}\text { muito } \\
\text { democrática }\end{array}$ & democrática & $\begin{array}{c}\text { pouco } \\
\text { democrática }\end{array}$ & Total \\
\hline VI Prudente & 1 & 2 & 1 & 4 \\
\hline Perus & & 2 & 2 & 4 \\
\hline Cid Tiradentes & & 3 & 1 & 4 \\
\hline Parelheiros & 1 & 1 & 2 & 4 \\
\hline Total & 2 & 8 & 6 & 16 \\
\hline
\end{tabular}

FONTE: VERISSSIMO, J. 2005 
Analisando-se os dados por período de início de participação dos conselheiros, nota-se que as opiniões estiveram muito próximas entre os três períodos. Contudo, quatro dos cinco conselheiros do período anterior e/ou até 1980 julgaram a organização de seus Conselhos muito democrática (01) ou democrática (03). Já 03 conselheiros que iniciaram sua participação entre 1981 e 1992 avaliaram que seus Conselhos têm organizações pouco democráticas.

\section{TABELA 29.1: GRAU DE DEMOCRATIZAÇÃO NA ORGANIZAÇÃO DOS CONSELHOS, POR PERÍODO DE INÍCIO DE PARTICIPAÇÃO.}

\begin{tabular}{|l|c|c|c|c|}
\hline \multicolumn{5}{|c|}{ Na sua opinião, a organização do CGS tem sido: } \\
\hline Período & $\begin{array}{c}\text { muito } \\
\text { democrática }\end{array}$ & democrática & $\begin{array}{c}\text { pouco } \\
\text { democrática }\end{array}$ & Total \\
\hline $\begin{array}{l}\text { período anterior } \\
\text { e/ou até 1980 }\end{array}$ & 1 & 3 & 1 & 5 \\
\hline $\begin{array}{l}\text { entre 1981 e } \\
1992\end{array}$ & & 3 & 3 & 6 \\
\hline depois de 2001 & 1 & 2 & 2 & 5 \\
\hline Total & 2 & 8 & 6 & 16 \\
\hline
\end{tabular}

FONTE: VERISSIMO, J. 2005

i) Avaliação das percepções cívico-republicanas dos conselheiros acerca das diretrizes do SUS (universalidade, integralidade e controle social).

Acerca das percepções dos conselheiros sobre suas atividades de participação nos Conselhos, propôs-se uma dinâmica visando a analisar suas avaliações sobre o sistema de saúde como um todo. Para tanto, baseando-se nas diretrizes normativas do SUS (publicidade, universalidade, integralidade e controle social) desenvolveu-se uma dinâmica baseada em estórias contadas para os conselheiros, as quais foram fundamentadas em situações do cotidiano de CGS. Com base nas historietas, fizeram-se questionamentos acerca das posturas tomadas ora pelos conselheiros, ora pelas administrações municipais das 
localidades fictícias criadas (todas as estórias, e as respectivas questões suscitadas, podem ser vistas no questionário anexo a este trabalho, questões de E.1 a E.4). Em seguida foi solicitado que eles declarassem concordância ou discordância em relação às situações descritas, utilizando-se para tanto, de uma escala na qual 01 significa discordo totalmente, e 10 concordo totalmente.

Esta dinâmica serviu de parâmetro para que se avaliassem os valores cívicorepublicanos dos conselheiros no que tange às suas percepções e práticas acerca do bem público.

A primeira narrativa falava de um Sr. que, após uma via crucis para conseguir atendimento na rede pública de saúde, fora vítima de negligência médica em uma pequena cidade do interior, e, depois da doença ter se agravado, foi encaminhado para tratamento no hospital da capital.

As pontuações indicaram que os conselheiros discordaram da peregrinação do paciente para obter atendimento: nove dos 16 conselheiros colocaram-se na posição um da escala quando questionados se a Prefeitura agiu de maneira correta.

Um viés um tanto localista aparece entre os conselherios de Cidade Tiradentes e Perus, Conselhos que obtiveram 0,61 e 0,70 respectivamente no índice de institucionalidade. Os conselheiros destes Conselhos afirmaram com mais força que os demais conselheiros que o hospital da cidade não deveria receber pacientes de outras localidades e que os moradores da capital deveriam se unir para impedir a vinda de pacientes de outros municípios. Contudo, todos os conselheiros demonstraram a força da idéia de que a participação gera dividendos ao afirmarem que a população da cidadezinha deveria reivindicar um hospital (11 conselheiros se posicionaram na posição 10 da escala). 
TABELA 30: AVALIAÇÃo CíVICO-REPUBLICANA (CASO E.1), POR CONSELHO DE QUE FAZ PARTE.

\begin{tabular}{|c|c|c|c|c|c|c|c|c|c|c|c|c|c|c|c|c|c|c|}
\hline \multicolumn{19}{|c|}{ Tratamento em outra cidade - E.1* } \\
\hline \multirow{2}{*}{$\begin{array}{l}\text { Conselho de que faz } \\
\text { parte }\end{array}$} & \multicolumn{4}{|c|}{$\begin{array}{c}\text { VI. } \\
\text { Prudente }\end{array}$} & \multicolumn{4}{|c|}{ Perus } & \multicolumn{5}{|c|}{$\begin{array}{c}\text { Cid. } \\
\text { Tiradentes }\end{array}$} & \multicolumn{5}{|c|}{ Parelheiros } \\
\hline & 1 & 4 & 5 & 10 & 1 & 5 & 9 & 10 & 1 & 5 & 6 & 7 & 10 & 1 & 3 & 0 & 8 & 10 \\
\hline $\begin{array}{l}\text { Prefeitura agiu } \\
\text { corretamente }\end{array}$ & 1 & 1 & 1 & 1 & 3 & & & 1 & 3 & & & 1 & & 2 & & & 1 & 1 \\
\hline $\begin{array}{l}\text { Prefeitura agiu de } \\
\text { maneira errada }\end{array}$ & 1 & 1 & & 2 & & 2 & & 2 & & 1 & & & 3 & 2 & & 1 & & 1 \\
\hline $\begin{array}{l}\text { Hospital da cidade não } \\
\text { deveria receber }\end{array}$ & 2 & 1 & 1 & & 2 & 1 & & 1 & 1 & 1 & & & 2 & 2 & & 1 & & 1 \\
\hline $\begin{array}{l}\text { Moradores cidadezinha } \\
\text { deveriam reivindicar } \\
\text { hospital }\end{array}$ & & & 1 & 3 & & & 1 & 3 & & 1 & & & 3 & 1 & & & 1 & 2 \\
\hline $\begin{array}{l}\text { Moradores da capital } \\
\text { deveriam se unir para } \\
\text { impedir vinda de } \\
\text { pacientes de outra } \\
\text { cidade }\end{array}$ & 4 & & & & 2 & & & 2 & 1 & 2 & & & 1 & 3 & 1 & & & \\
\hline
\end{tabular}

FONTE: VERISSIMO, J. 2005.

*Respostas múltiplas

Ao se agregar os conselheiros por período de início de participação, percebe-se que os padrões de respostas mantiveram-se os mesmos, não apresentando variações muito drásticas entre si. Os conselheiros que iniciaram sua participação em 2001 mostraram forte apelo para a participação: 04 conselheiros deste grupo se posicionaram " 10 " na escala quando perguntados se os moradores da pequena cidade deveriam se unir para reivindicar um hospital (o padrão se manteve mesmo quando a participação significaria a restrição da universalidade do atendimento, como é caso deste grupo ter demonstrado essa inclinação quando 03 de seus conselheiros declararam que os "moradores da capital deveriam se unir para impedir a vinda de pacientes de outras cidades"). 


\section{TABELA 30.1: AVALIAÇÃO CÍVICO-REPUBLICANA (CASO E.1), POR PERÍODO DE INÍCIO DE PARTICIPAÇÃO.}

\begin{tabular}{|c|c|c|c|c|c|c|c|c|c|c|c|c|}
\hline \multicolumn{13}{|c|}{ Tratamento em outra cidade - E.1 ${ }^{*}$} \\
\hline \multirow{2}{*}{$\begin{array}{l}\text { Período/escala } \\
\text { Avaliação }\end{array}$} & \multicolumn{3}{|c|}{$\begin{array}{c}\text { período } \\
\text { anterior } \\
\text { elou até } \\
1980\end{array}$} & \multicolumn{6}{|c|}{ entre 1981 e 1992} & \multicolumn{3}{|c|}{$\begin{array}{c}\text { depois de } \\
2001\end{array}$} \\
\hline & 1 & \begin{tabular}{l|l|}
4 & 5 \\
\end{tabular} & 10 & 1 & 3 & 5 & 68 & 9 & 10 & 1 & 45 & 510 \\
\hline $\begin{array}{l}\text { Prefeitura agiu } \\
\text { corretamente }\end{array}$ & 2 & 1 & 1 & 3 & & 1 & & & & 4 & & \\
\hline $\begin{array}{l}\text { Prefeitura agiu de } \\
\text { maneira errada }\end{array}$ & 3 & 1 & 1 & & & 2 & 1 & & 3 & & 1 & 4 \\
\hline $\begin{array}{l}\text { Hospital da cidade } \\
\text { não deveria receber }\end{array}$ & 3 & 1 & 1 & & & & & & & & & \\
\hline $\begin{array}{l}\text { Moradores } \\
\text { cidadezinha deveriam } \\
\text { reivindicar hospital }\end{array}$ & 1 & & 4 & & & 1 & & 1 & 3 & & 1 & 4 \\
\hline $\begin{array}{l}\text { Moradores da capital } \\
\text { deveriam se unir para } \\
\text { impedir vinda de } \\
\text { pacientes de outra } \\
\text { cidade }\end{array}$ & 4 & 1 & & 4 & 1 & 1 & & & & 2 & & \\
\hline
\end{tabular}

FONTE: VERISSIMO, J. 2005.

*Respostas múltiplas

A segunda situação proposta para análise narrou a estória de um município onde o atendimento à saúde corria dentro de todos os padrões de excelência, até o acampamento de centenas de Sem Terra na região. Dado este fato, a Prefeitura proibiu o atendimento aos Sem Terra alegando que se eles fossem acolhidos, o atendimento aos locais pioraria.

Percebe-se que esta tabela demonstra que de maneira geral os conselheiros discordaram que os Sem Terra não fossem atendidos, achando que eles deveriam "ser atendidos de qualquer maneira". Mas quando se mencionou a questão da reivindicação, seja a ida do MST ao Conselho Municipal de Saúde (CMS), ou a ida dos três "segmentos" ao governo do Estado para solicitar mais verbas para o 
atendimento (alternativa 5), metade dos conselheiros entrevistados posicionou-se na posição "10" da escala, demonstrando concordância veemente com a alternativa.

\section{TABELA 31: AVALIAÇÃO CíVICO-REPUBLICANA (CASO E.3), POR CONSELHO DE QUE FAZ PARTE.}

\begin{tabular}{|c|c|c|c|c|c|c|c|c|c|c|c|c|c|c|c|c|c|c|c|c|c|c|c|c|}
\hline \multicolumn{25}{|c|}{ Atendimento aos Sem Terra* - E.3. } \\
\hline $\begin{array}{l}\text { Conselho de que } \\
\text { faz parte }\end{array}$ & \multicolumn{6}{|c|}{ VI Prudente } & \multicolumn{5}{|c|}{ Perus } & \multicolumn{6}{|c|}{ Cid Tiradentes } & \multicolumn{7}{|c|}{ Parelheiros } \\
\hline escala & 1 & 2 & 3 & 5 & 8 & 10 & 1 & 5 & 6 & 8 & 10 & 1 & 5 & 6 & 7 & 8 & 10 & 1 & 5 & 6 & 7 & 8 & 9 & 10 \\
\hline $\begin{array}{l}1 \text { - Atitude correta, } \\
\text { quem paga imposto } \\
\text { tem prioridade no } \\
\text { atendimento }\end{array}$ & 1 & & 1 & 1 & 1 & & 3 & & & & 1 & 2 & 2 & & & & & 4 & & & & & & \\
\hline $\begin{array}{l}2 \text { - Sem Terra } \\
\text { deveriam reivindicar } \\
\text { verbas para gov do } \\
\text { Estado }\end{array}$ & 1 & & 1 & & 1 & 1 & 1 & & & & 3 & 1 & 1 & & 1 & & 1 & 3 & & & 1 & & & \\
\hline $\begin{array}{l}3 \text { - Deveriam ter sido } \\
\text { atendidos de qualquer } \\
\text { maneira }\end{array}$ & & & & & 2 & 2 & & & & 1 & 3 & & 1 & & 1 & & 2 & & & & & 2 & & 2 \\
\hline $\begin{array}{l}4 \text { - Deveriam ir ao } \\
\text { CMS requerer } \\
\text { atendimento }\end{array}$ & & & 1 & & & 3 & 1 & & 1 & & 2 & & & & 1 & & 3 & & & & 1 & 1 & 1 & 1 \\
\hline $\begin{array}{l}5 \text { - CMS, MST e PM } \\
\text { deveria requerer } \\
\text { verbas para governo } \\
\text { do Estado, para depois } \\
\text { atenderem os ST }\end{array}$ & 1 & & & & & 3 & 1 & 1 & & & 2 & 1 & & & & 1 & 2 & 1 & 1 & 1 & & & & 1 \\
\hline
\end{tabular}

FONTE: VERISSIMO, J. 2005.

*Respostas múltiplas

Olhando-se esta mesma tabela com os dados agregados por período de início de participação, percebe-se que os conselheiros que iniciaram sua participação depois de 2001 julgaram que os Sem Terra deveriam ser atendidos após haver verba para tal: no quinto tópico da tabela abaixo, 01 conselheiro deste grupo se posicionou no meio da escala, " 5 ", e os demais ( 04 conselheiros) posicionaram-se na escala máxima de concordância da tabela, "10", em relação a esta alternativa. 
TABELA 31.1: AVALIAÇÃO CÍVICO-REPUBLICANA (CASO E.3), POR PERÍODO DE INÍCIO DE PARTICIPAÇÃO.

\begin{tabular}{|c|c|c|c|c|c|c|c|c|c|c|c|c|c|c|c|c|c|c|}
\hline \multicolumn{19}{|c|}{ Atendimento aos Sem Terra* - E.3 } \\
\hline \multirow{2}{*}{$\begin{array}{l}\text { Período / escala } \\
\text { Avaliação } \\
\end{array}$} & \multicolumn{7}{|c|}{$\begin{array}{c}\text { período anterior } \\
\text { e/ou até } 1980\end{array}$} & \multicolumn{6}{|c|}{$\begin{array}{c}\text { entre } 1981 \text { e } \\
1992\end{array}$} & \multicolumn{5}{|c|}{$\begin{array}{c}\text { depois de } \\
2001\end{array}$} \\
\hline & 1 & 3 & 5 & 7 & 8 & 9 & 10 & 1 & 5 & 6 & 7 & 8 & 10 & 1 & 5 & 6 & 8 & 10 \\
\hline $\begin{array}{l}1 \text { - Atitude correta, } \\
\text { quem paga imposto } \\
\text { tem prioridade no } \\
\text { atendimento }\end{array}$ & 3 & & 1 & & 1 & & & 5 & 1 & & & & & 3 & 1 & & & 1 \\
\hline $\begin{array}{l}2 \text { - Sem Terra } \\
\text { deveriam reivindicar } \\
\text { verbas para gov do } \\
\text { Estado }\end{array}$ & 2 & 1 & 1 & 1 & & & & 3 & & & 1 & & 2 & 1 & & & 1 & 3 \\
\hline $\begin{array}{l}3 \text { - Deveriam ter } \\
\text { sido atendidos de } \\
\text { qualquer maneira }\end{array}$ & & & 1 & & 2 & & 2 & & & & 1 & 1 & 3 & & & & 2 & 3 \\
\hline $\begin{array}{l}4 \text { - Deveriam ir ao } \\
\text { CMS requerer } \\
\text { atendimento }\end{array}$ & 1 & 1 & & & & 1 & 2 & & & & 2 & 1 & 3 & & & 1 & & 4 \\
\hline $\begin{array}{l}5 \text { - CMS, MST e PM } \\
\text { deveria requerer } \\
\text { verbas para governo } \\
\text { do Estado, para } \\
\text { depois atenderem } \\
\text { os ST }\end{array}$ & 2 & & & & & & 3 & 2 & 1 & 1 & & 1 & 1 & & 1 & & & 4 \\
\hline
\end{tabular}

FONTE: VERISSIMO, J. 2005.

*Respostas múltiplas

O último estímulo aos conselheiros foi o conto de um conselheiro, muito querido por todos da região, que tinha um filho construindo um "puxadinho" em seu terreno, pois havia se casado. Em uma obra de um posto de saúde sobraram alguns materiais, e este conselheiro pediu ao Conselho que the desse o material que sobrou da obra, e o Conselho permitiu. 
Os dados dizem que os conselheiros foram, em sua maioria, contrários ao conselheiro poder pegar o material de qualquer maneira. Vê-se isto no primeiro item da tabela: a maioria dos conselheiros posicionou-se de cinco para baixo na escala. Neste sentido, nota-se que todos os entrevistados foram unânimes ao terem afirmado que o material não poderia ter sido pego de qualquer maneira. À fraca exceção de Perus, os conselheiros julgaram não ter autoridade para dar o material para ninguém (tópico 04 da tabela abaixo). Pode-se ver contudo, uma convergência entre os conselheiros para que este material fosse doado a algum movimento de moradia (ponto 03 na tabela).

\section{TABELA 32: AVALIAÇÃO CÍVICO-REPUBLICANA (CASO E.4), POR CONSELHO DE QUE FAZ PARTE.}

\begin{tabular}{|c|c|c|c|c|c|c|c|c|c|c|c|c|c|c|c|c|c|c|c|c|c|c|c|c|}
\hline \multicolumn{25}{|c|}{ Atendimento aos Sem Terra* } \\
\hline $\begin{array}{l}\text { Conselho de que } \\
\text { faz parte }\end{array}$ & \multicolumn{6}{|c|}{ VI Prudente } & \multicolumn{5}{|c|}{ Perus } & \multicolumn{6}{|c|}{ Cid Tiradentes } & \multicolumn{7}{|c|}{ Parelheiros } \\
\hline Avaliação/escala & $1 \mid 2$ & $2 \mid 3$ & 5 & 6 & 8 ( 1 & 10 & 1 & 56 & 8 & 1( & 1 & 2 & 4 & 5 & $6 \mid 7$ & 8 & 10 & 1 & 2 & 56 & 7 & 8 & 9 & 10 \\
\hline $\begin{array}{l}1 \text { - Fez bem ao } \\
\text { pedir, o CMS é } \\
\text { soberano }\end{array}$ & 3 & & & & & 1 & 2 & & & 2 & 1 & & 1 & & & 2 & & 1 & & 1 & & & 1 & 1 \\
\hline $\begin{array}{l}2 \text { - Poderia pegar } \\
\text { de qualquer } \\
\text { maneira, o material } \\
\text { sobrou }\end{array}$ & 4 & & & & & & 4 & & & & 4 & & & & & & & 5 & 2 & & & & & \\
\hline $\begin{array}{l}3 \text { - Deveria ter dado } \\
\text { a algum Movimento } \\
\text { de Moradia }\end{array}$ & 2 & & 1 & 1 & & & 2 & & & 2 & & 1 & & 1 & & & 2 & & & \begin{tabular}{l|l}
1 & 1
\end{tabular} & & & & 2 \\
\hline $\begin{array}{l}4 \text { - CMS não tem } \\
\text { autoridade, deveria } \\
\text { ter pedido } \\
\text { sindicância para } \\
\text { apurar a sobra de } \\
\text { materiais }\end{array}$ & & & & 1 & & 3 & 1 & 1 & 1 & 1 & & 1 & & & & & 3 & & & & & & 1 & 2 \\
\hline
\end{tabular}

FONTE: VERISSIMO, J. 2005.

${ }^{*}$ Respostas múltiplas 
Agrupando-se os conselheiros por período de início de participação, os padrões de respostas da tabela anterior praticamente se repetem. Duas peculiaridades se fazem notar, contudo: o grupo que iniciou sua participação no período anterior e/ou até 1980 mostrou-se contrário à idéia de que o conselheiro fez bem ao pedir o material para o Conselho: 03 conselheiros posicionaram-se no ponto " 01 " da escala e um no ponto "04" (ver item 01 da tabela). Contrariamente, 03 dos conselheiros que começaram suas atividades participacionistas em 2001 posicionaram-se completamente a favor.

Este mesmo grupo - que iniciou sua vida associativa depois de 2001 - foi fortemente contrário à proposição de que se desse este material para um movimento de moradia que possuísse mutirão: todos os conselheiros deste grupo posicionaram-se até o ponto cinco da escala (03 na posição um e 02 na posição cinco).

\section{TABELA 32.1: AVALIAÇÃO CÍVICO-REPUBLICANA (CASO E.4), POR PERÍODO DE INÍCIO DE PARTICIPAÇÃO.}

\begin{tabular}{|c|c|c|c|c|c|c|c|c|c|c|c|c|c|c|c|c|c|}
\hline \multicolumn{18}{|c|}{ Doação privada de material público- E. 4* } \\
\hline \multirow{2}{*}{$\begin{array}{l}\text { Período / escala } \\
\text { Avaliação }\end{array}$} & \multicolumn{7}{|c|}{$\begin{array}{l}\text { período anterior } \\
\text { e/ou até } 1980\end{array}$} & \multicolumn{6}{|c|}{$\begin{array}{c}\text { entre } 1981 \mathrm{e} \\
1992\end{array}$} & \multicolumn{4}{|c|}{$\begin{array}{c}\text { depois de } \\
2001\end{array}$} \\
\hline & 1 & 2 & 4 & 5 & 6 & 9 & 10 & 1 & 2 & 5 & 6 & 8 & 10 & 1 & & 8 & 10 \\
\hline $\begin{array}{l}1 \text { - Fez bem ao pedir, } \\
\text { o CMS é soberano }\end{array}$ & 3 & & 1 & & & 1 & & 2 & & 1 & & 1 & 1 & 2 & & & 3 \\
\hline $\begin{array}{l}2 \text { - Poderia pegar de } \\
\text { qualquer maneira, o } \\
\text { material sobrou }\end{array}$ & 4 & 1 & & & & & & 6 & & & & & & 5 & & & \\
\hline $\begin{array}{l}3 \text { - Deveria ter dado } \\
\text { a algum Movimento } \\
\text { de Moradia }\end{array}$ & & & & & 1 & & 4 & 1 & 1 & 1 & 1 & & 2 & 3 & 2 & & \\
\hline $\begin{array}{l}4 \text { - CMS não tem } \\
\text { autoridade, deveria } \\
\text { ter pedido } \\
\text { sindicância para } \\
\text { apurar a sobra de } \\
\text { materiais }\end{array}$ & & & & 1 & & & 2 & & 1 & & & 1 & 4 & 1 & & 1 & 3 \\
\hline
\end{tabular}

FONTE: VERISSIMO, J. 2005.

*Respostas múltiplas 
Refletindo-se acerca dos dados, ainda de maneira generalista, pode-se perceber que as variações nas respostas dos conselheiros acentuaram-se quando estes foram observados por período de início de participação, em comparação com sua variação quando agrupadas por Conselhos.

Desta maneira, soma-se à nossa hipótese original - os valores, práticas e percepções políticas dos conselheiros variam de acordo com o desenho institucional dos Conselhos de Saúde - a hipótese complementar de que os valores, práticas e percepções políticas dos conselheiros variam de acordo com o período de início de sua participação.

Apresentar-se-ão os resultados das análises dos dados no capítulo que se segue. 


\section{Capítulo IV - Avaliação do capital social, cultura cívica e percepções acerca das diretrizes do SUS.}

Com base nos dados apresentados, passo à sua análise. Para tanto, os dados foram agrupados em indicadores - por CGS e por período de início de participação dos conselheiros. Nos dois casos, levaram-se em consideração como variáveis dependentes: 1) o capital social e a cultura cívica dos conselheiros; e 2) a avaliação cívico-republicana dos conselheiros, feita com base nas estórias a eles contadas.

\section{Os indicadores}

Para a análise dos dados, construíram-se indicadores objetivos visando-se a dinamizar a comparação entre o perfil dos conselheiros tanto quando agregados por Conselhos dos quais fazem parte, quanto agrupados por período de tempo de participação.

Com estes indicadores conseguiu-se agregar diversas características de um mesmo fenômeno, como acesso a diversos veículos de informação (para os indicadores de informação geral e política), e variados valores sociais e políticos (para o indicador de valores sócio-políticos), por exemplo.

Tais indicadores foram construídos de acordo com as hipóteses propostas para o trabalho: i) os valores, práticas e percepções políticas dos conselheiros variam de acordo com o desenho institucional dos Conselhos de Saúde; ii) os valores, práticas e percepções políticas dos conselheiros variam de acordo com o período de início de sua participação.

Para tanto, estabeleceu-se um valor de ponderação para cada resposta dada pelos conselheiros às questões aplicadas e apresentadas no capítulo anterior. Para as respostas que indicaram associação com práticas mais democráticas e cívicas (como ver noticiário todos os dias, conversar sobre política com amigos, 
participar de reuniões para resolver problemas do bairro ou cidade, participar de mais eventos sociais) estabeleceu-se um valor de ponderação maior.

A suposição teórica que sustenta estas ponderações é a de que quanto maior o contato que a pessoa tiver com veículos de informação, mais participar de organizações associativas, maior for sua capilaridade social e mais cívicos forem seus valores e percepções acerca das instituições democráticas, há mais chances de que as avaliações e julgamentos políticos desta pessoa sejam mais críticos no sentido de que suas performances individuais levem em consideração a dimensão pública das relações sociais.

Os resultados das ponderações foram somados e agregados. Desta forma, os resultados que se seguem nas células das tabelas abaixo representam estas agregações, não significando a quantidade de conselheiros que respondeu a uma questão específica. ${ }^{35}$

\section{i) Capital Social e Cultura Cívica.}

Estes dois tópicos traduzem a existência de redes sociais de relacionamentos que conectam as pessoas, sendo pautadas e frutificando normas de reciprocidade e confiança generalizada e nas instituições, bem como desenvolvendo tolerância para com as pessoas. Estes fatores favorecem que os indivíduos sejam mais propensos a envolverem-se em distintas formas de ação coletiva, por serem mais receptivos à interação social. Espera-se que pessoas com elevado capital social e cultura cívica tenham boa informação política e geral, vida associativa e social ativas, tenham valores políticos democráticos e apresentem-se mais tolerantes e confiantes.

\footnotetext{
${ }^{35}$ Todas as ponderações e agregações podem ser vistas no apêndice "b" deste trabalho.
} 


\section{a) Indicador de Informação Geral e Política ${ }^{36}$}

O acesso à informação geral e política demonstra a propensão das pessoas a avaliações mais críticas acerca dos acontecimentos políticos e sociais. Pessoas mais informadas têm mais facilidade em opinar acerca da coisa pública e são mais conscientes ao participar das decisões políticas. Perguntou-se aos conselheiros se eles lêem jornais, escutam rádio, assistem à televisão, e usam a Internet, e com que freqüências fazem isso.

O peso dado às respostas foi o seguinte: se o conselheiro respondeu que teve contato com o veículo de informação diariamente ou quase todos os dias, multiplicou-se o número de respondentes $(\mathrm{N})$ por 04 ; se algumas vezes por semana por 03; e se quase nunca por 02. Não foi atribuído fator de ponderação se o conselheiro declarou não ter o hábito (ver tabelas 01 a 1.3 no apêndice "b").

Ao se agrupar os conselheiros em Conselhos, vê-se que os resultados apresentaram-se muito próximos entre si, tendo apenas os conselheiros de Parelheiros demonstrado pouco acesso à informação geral.

Já o indicador de informação política - formado por perguntas que mediram se o conselheiro assiste noticiário sobre política, lê sobre política, discute sobre política com amigos e participa de reuniões para discutir sobre política -, foi menor entre os conselheiros de Perus.

Isto não quer dizer que as pessoas deste Conselho não tenham declarado se informar sobre política ou participar de discussões ou eventos políticos, mas que elas disseram participar com menor intensidade, como pode ser constatado nas tabelas 02 e 2.1, no mesmo apêndice citado acima.

\footnotetext{
${ }^{36}$ Para estes indicadores de informação o maior valor possível é 72 pontos, e o menor é 0.
} 
TABELA 01: INDICADOR DE INFORMAÇÃO GERAL, POR CONSELHO QUE FAZ PARTE.

\begin{tabular}{|l|c|c|c|c|}
\hline \multicolumn{5}{|c|}{ Indicador de Informação Geral* } \\
\hline $\begin{array}{l}\text { Conselho } \\
\text { que faz } \\
\text { parte }\end{array}$ & VI Prudente & Perus & Cid Tiradentes & Parelheiros \\
\hline Pontuação & $\mathbf{4 1}$ & $\mathbf{4 7}$ & $\mathbf{4 3}$ & $\mathbf{3 3}$ \\
\hline
\end{tabular}

* TV, rádio, jornal e Internet FONTE: VERÍSSIMO, 2005.

TABELA 02: INDICADOR DE INFORMAÇÃO POLÍTICA, POR CONSELHO QUE FAZ PARTE.

\begin{tabular}{|c|c|c|c|c|}
\hline \multicolumn{5}{|c|}{ Indicador de Informação Política* } \\
\hline $\begin{array}{c}\text { Conselho } \\
\text { que faz } \\
\text { parte }\end{array}$ & VI Prudente & Perus & Cid Tiradentes & Parelheiros \\
\hline Pontuação & 35 & 29 & 34 & 44 \\
\hline
\end{tabular}

* assiste noticiário sobre política, lê sobre política, discute sobre política com amigos e participa de reuniões para discutir sobre política FONTE: VERÍSSIMO, 2005.

Já ao se agruparem os conselheiros por período de início de participação ${ }^{37}$, podese constatar que os conselheiros que iniciaram sua participação no período anterior e/ou até o ano de 1980 declararam acessar menos os veículos de informação geral. Já em relação à informação política, foram os que iniciaram sua vida participativa depois de 2001 os que afirmaram ter acessado menos conteúdos políticos. As pessoas que iniciaram sua participação em atividades associativas entre os anos de 1981 e 1992 foram as que se mostraram mais bem informadas em ambos aspectos.

\footnotetext{
${ }^{37}$ A década de 1990 está representada apenas até o ano de 1992 pelo fato de, em nosso universo pesquisado, não haver casos de início de participação entre 1993 e 2000.
} 


\section{TABELA 1.1: INDICADOR DE INFORMAÇÃO GERAL, POR PERÍODO DE INÍCIO DE PARTICIPAÇÃO.}

\begin{tabular}{|c|c|c|c|}
\hline \multicolumn{4}{|c|}{ Indicador de Informação Geral $^{*}$} \\
\hline Período & $\begin{array}{c}\text { período } \\
\text { anterior } \\
\text { e/ou até } \\
1980\end{array}$ & $\begin{array}{c}\text { entre } \\
1981 \text { e } \\
1992\end{array}$ & $\begin{array}{c}\text { depois de } \\
2001\end{array}$ \\
\hline Pontuação & $\mathbf{4 5}$ & $\mathbf{6 5}$ & $\mathbf{5 4}$ \\
\hline
\end{tabular}

${ }^{*}$ TV, rádio, jornal e Internet.

FONTE: VERÍSSIMO, 2005.

\section{TABELA 2.2: INDICADOR DE INFORMAÇÃO POLÍTICA, POR PERÍODO DE INÍCIO DE PARTICIPAÇÃO.}

\begin{tabular}{|l|c|c|c|}
\hline \multicolumn{4}{|c|}{ Indicador de Informação Política* } \\
\hline Período & $\begin{array}{l}\text { período } \\
\text { anterior } \\
\text { e/ou até } \\
1980\end{array}$ & $\begin{array}{l}\text { entre } \\
1981 \text { e } \\
1992\end{array}$ & $\begin{array}{l}\text { depois de } \\
2001\end{array}$ \\
\hline Pontuação & $\mathbf{5 3}$ & $\mathbf{6 2}$ & $\mathbf{2 6}$ \\
\hline
\end{tabular}

FONTE: VERÍSSIMO, 2005.

* assiste noticiário sobre política, lê sobre política, discute sobre política com amigos e participa de reuniões para discutir sobre política.

Também se pode perceber na Tabela 1.1, no apêndice " $b$ " do trabalho, que está se tratando de pessoas que com muita freqüência disseram assistir à televisão, ouvir o rádio e ler jornais, não apenas para informações gerais, mas também em busca de informações políticas.

b) Indicador de Valores Sócio-políticos ${ }^{38}$

Os valores sócio-políticos dos entrevistados foram medidos levando-se em consideração seu orgulho nacional, os tipos de ações políticas das quais eles já fizeram parte (assinaturas de manifestos, boicotes, manifestações, greves e ocupações), como avaliaram diversos regimes de governo (ditadura, tecnocracia,

\footnotetext{
${ }^{38}$ Os valores deste indicador variam de 0 a 96.
} 
extinção do parlamento e democracia), e que sentimentos declararam ter pela política. Levando-se estas variáveis em conta, elaborou-se um indicador de valores sócio-políticos, no qual quanto mais elevados os números, mais democráticos, orgulhosos de serem brasileiros e politicamente ativos se disseram ser os conselheiros. ${ }^{39}$

\section{TABELA 03: INDICADOR DE VALORES SÓCIO-POLÍTICOS, POR CONSELHO QUE FAZ PARTE.}

\begin{tabular}{|l|c|c|c|c|}
\hline \multicolumn{5}{|c|}{ Indicador de Valores Sócio-Políticos } \\
\hline $\begin{array}{c}\text { Indicador / Conselho que faz } \\
\text { parte }\end{array}$ & VI. Prudente & Perus & $\begin{array}{c}\text { Cid. } \\
\text { Tiradentes }\end{array}$ & Parelheiros \\
\hline Atividade Política & 18 & 24 & 29 & 26 \\
\hline Valores Democráticos & 8 & 8 & 8 & 8 \\
\hline Orgulho Nacional & 12 & 8 & 8 & 7 \\
\hline Interesse em relação à política & 3 & 2 & 3 & 4 \\
\hline Total & $\mathbf{4 1}$ & $\mathbf{4 2}$ & $\mathbf{4 8}$ & $\mathbf{4 5}$ \\
\hline
\end{tabular}

FONTE: VERÍSSIMO, 2005.

Observando-se a tabela, constata-se que os valores, como os demais indicadores apresentados antes, estão muito próximos entre si. Deve-se chamar a atenção para a variável que deu aos conselheiros de Cidade Tiradentes o maior valor, que é a de atividade política. Isto demonstra que, excetuando-se a prática de ocupação de prédios, os conselheiros desta localidade disseram já ter exercido todas as outras atividades citadas acima (ver tabela 03, apêndice "b").

Analisando-se os dados, tendo-se agregado os conselheiros por período de início de participação, nota-se uma diferença. Os conselheiros que começaram sua vida associativa depois de 2001 apresentaram uma freqüência de atividade política bastante abaixo dos dois outros grupos. Os conselheiros deste período também se manifestaram menos confortáveis em relação à política.

\footnotetext{
${ }^{39}$ As tabelas e ponderações utilizadas para construção deste indicador podem ser vistas no item III do apêndice "b": Indicador de Valores Sócio-Políticos.
} 


\section{TABELA 3.1: INDICADOR DE VALORES SÓCIO-POLÍTICOS, POR PERÍODO DE INÍCIO DE PARTICIPAÇÃO.}

\begin{tabular}{|l|c|c|c|}
\hline \multicolumn{4}{|c|}{ Indicador de Valores Sócio-Políticos } \\
\hline Indicador / Período & $\begin{array}{c}\text { período } \\
\text { anterior e/ou } \\
\text { até 1980 }\end{array}$ & $\begin{array}{c}\text { entre 1981 e } \\
1992\end{array}$ & depois de 2001 \\
\hline Atividade Política & 32 & 47 & 18 \\
\hline Valores Democráticos & 10 & 12 & 10 \\
\hline Orgulho Nacional & 9 & 12 & 14 \\
\hline Interesse em relação à política & 5 & 6 & 1 \\
\hline Total & $\mathbf{5 6}$ & $\mathbf{7 7}$ & $\mathbf{4 3}$ \\
\hline
\end{tabular}

FONTE: VERÍSSIMO, 2005.

c) Indicador de Participação e Associativismo ${ }^{40}$

Ao se olhar para a participação associativa dos conselheiros dos Conselhos de Saúde das Subprefeituras, constata-se que a participação formal em diversas associações demonstrou-se bastante alta. De maneira geral, pode-se verificar que todos os 16 conselheiros entrevistados disseram ter uma vida associativa vibrante e participar de mais de um movimento, não necessariamente vinculado à questão da saúde (podendo variar drasticamente, como Movimento Sem Terra, partidos políticos e sindicatos). A tabela abaixo demonstra a quantidade de diferentes associações das quais participam os conselheiros $(\mathbf{N})$, e a pontuação que obtiveram no indicador:

\footnotetext{
${ }^{40}$ Quanto maior a pontuação obtida pelos conselheiros de determinado Conselho ou período de início de participação, maior a aproximação com os conceitos de capital social e cultura cívica.
} 
TABELA 04: AVALIAÇÃO DO ASSOCIATIVISMO, POR CONSELHO QUE FAZ PARTE.

\begin{tabular}{|l|c|c|c|c|c|c|c|c|}
\hline \multicolumn{7}{|c|}{ Indicador de Participação e Associativismo** } \\
\hline \multirow{2}{*}{ Participa das associações* } & VI. Prudente & \multicolumn{2}{|c|}{ Perus } & \multicolumn{2}{c|}{ Cid. } & \multicolumn{2}{c|}{ Tiradentes } & Parelheiros \\
\cline { 2 - 10 } & $\mathbf{N}$ & Pontos & $\mathbf{N}$ & Pontos & $\mathbf{N}$ & Pontos & $\mathbf{N}$ & Pontos \\
\hline formalmente $x$ 4 & 8 & 32 & 11 & 44 & 12 & 48 & 11 & 44 \\
\hline esporadicamente $x$ 3 & 7 & 21 & 8 & 24 & 9 & 27 & 8 & 24 \\
\hline já participei, não mais $x$ 2 & 1 & 2 & 3 & 6 & 3 & 6 & 5 & 10 \\
\hline Total & 16 & $\mathbf{5 5}$ & 22 & $\mathbf{7 4}$ & 24 & $\mathbf{8 1}$ & 24 & $\mathbf{7 8}$ \\
\hline
\end{tabular}

FONTE: VERÍSSIMO, 2005.

${ }^{*}$ Respostas múltiplas.

**Tabelas com a descrição das associações levadas em consideração no apêndice "b", item IV.

Como se pode perceber, os conselheiros de Vila Prudente afirmaram ter uma prática participacionista menos intensa em relação aos conselheiros dos demais Distritos. Os dos outros três Conselhos apresentaram pontuação muito próxima em seus resultados, com uma leve preponderância, em Parelheiros, dos conselheiros afirmarem terem deixado de participar de associações.

Curioso que, ao se olhar para os agrupamentos por período de início de associativismo nota-se, mais uma vez, que o período que iniciou sua participação comunitária depois de 2001 demonstrou ter participação significativamente inferior aos dois outros, sendo o grupo "entre 1981 e 1992" o que apresentou mais força associativa. 
TABELA 4.1: IDICADOR DE ASSOCIATIVISMO, POR PERÍODO DE INÍCIO DE PARTICIPAÇÃO.

\begin{tabular}{|l|c|c|c|c|c|c|}
\hline \multicolumn{6}{|c|}{ Indicador de Participação e Associativismo* } \\
\hline \multirow{2}{*}{ Participa das associações** } & $\begin{array}{c}\text { período } \\
\text { anterior e/ou } \\
\text { até } 1980\end{array}$ & $\begin{array}{c}\text { entre } 1981 \text { e } \\
1992\end{array}$ & \multicolumn{2}{c|}{$\begin{array}{c}\text { depois de } \\
2001\end{array}$} \\
\cline { 2 - 7 } & $\mathbf{N}$ & Pontos & $\mathbf{N}$ & Pontos & $\mathbf{N}$ & Pontos \\
\hline formalmente $\times$ 4 & 18 & 72 & 21 & 84 & 6 & 24 \\
\hline esporadicamente $\times 3$ & 11 & 33 & 18 & 54 & 3 & 9 \\
\hline já participei, não mais $\times 2$ & 8 & 16 & 3 & 6 & 2 & 4 \\
\hline Total & 37 & $\mathbf{1 2 1}$ & 42 & $\mathbf{1 4 4}$ & 11 & $\mathbf{3 7}$ \\
\hline
\end{tabular}

FONTE: VERÍSSIMO, 2005.

${ }^{*}$ Respostas múltiplas

** Tabela com a descrição das associações levadas em consideração no apêndice "b", item IV.

A suposição teórica com a qual trabalho é a de que esta vida associativa vibrante permite a geração e o fortalecimento de normas de reciprocidade e confiança generalizada e nas instituições, bem como auxilia no desenvolvimento da tolerância para com as pessoas de uma maneira geral, o que suscita relações horizontais de reciprocidade e desenvolvem valores democráticos.

d) Indicador de Tolerância ${ }^{41}$

Para se medir tolerância, propôs-se dois temas polêmicos nas opiniões da sociedade brasileira para reflexão dos conselheiros: a homossexualidade e o aborto. Assim, convidaram-se os conselheiros a se posicionarem em uma escala na qual 01 significa uma prática nunca aceitável e 10 uma prática sempre aceitável. Para se obter o indicador, somaram-se os valores dos autoposicionamentos declarados pelos conselheiros (por Conselho que fazem parte e por período de início de participação). Por exemplo, um Conselho que

${ }^{41}$ Dada a escala de 10 pontos, o maior valor que poderia ter sido atingido pelo conjunto dos conselheiros é de 40 pontos, quando agregados por Conselhos, e de 60 pontos, se agregados por período de início de participação. 
tenha apresentado três conselheiros na posição 10 da escala e um na sete somou 37 pontos no indicador.

Assim, a tolerância em relação à homossexualidade mostrou-se muito mais ampla do que a tolerância em relação ao aborto. O mais curioso é que os conselheiros de Vila Prudente, que se mostraram mais tolerantes em relação à homossexualidade, mostraram-se os menos tolerantes em relação ao aborto. Abaixo se tem os dados do indicador sintético de tolerância (que leva em conta a soma das duas escalas). Percebe-se que os conselheiros de Cidade Tiradentes e Parelheiros apresentaram-se os menos tolerantes:

\section{TABELA 05: INDICADOR DE TOLERÂNCIA, POR CONSELHO QUE FAZ} PARTE.

\begin{tabular}{|l|c|}
\hline \multicolumn{2}{|l|}{ Indicador de tolerância } \\
\hline Conselho & Total \\
\hline VI Prudente & $\mathbf{4 6}$ \\
\hline Perus & $\mathbf{5 1}$ \\
\hline Cid Tiradentes & $\mathbf{3 4}$ \\
\hline Parelheiros & $\mathbf{3 4}$ \\
\hline
\end{tabular}

Analisando-se os dados agrupados por período de início de participação dos conselheiros, percebe-se que o grupo que iniciou sua participação em 2001 declarou-se mais tolerante que os demais.

TABELA 5.1: INDICADOR DE TOLERÂNCIA, POR PERÍODO DE INÍCIO DE PARTICIPAÇÃO.

\begin{tabular}{|l|c|c|}
\hline \multicolumn{2}{|c|}{ Indicador de Tolerância } \\
\hline Grupo & N & Total \\
\hline $\begin{array}{l}\text { período anterior e/ou } \\
\text { até 1980 }\end{array}$ & 5 & $\mathbf{3 4}$ \\
\hline entre 1981 e 1992 & 6 & $\mathbf{5 2}$ \\
\hline depois de 2001 & 5 & $\mathbf{5 9}$ \\
\hline FONTE: VERÍ́SSIMO, 2005.
\end{tabular}


e) Indicador de Capital Social ${ }^{42}$

Para verificar-se o grau de capital social dos conselheiros, elaborou-se uma medida levando-se em consideração: quantidade de visitas a parentes, passeios como cinema, festas e parques, idas à igreja, ao estádio de futebol, a bares ou restaurantes, favores feitos entre vizinhos e participação em reuniões para solucionar problemas do bairro. Os resultados indicam a somatória dos pontos atribuídos a cada conselheiro, quanto maior o número, mais capital social.

TABELA 06: INDICADOR DE CAPITAL SOCIAL, POR CONSELHO QUE FAZ PARTE. ${ }^{43}$

\begin{tabular}{|l|c|c|c|c|}
\hline \multicolumn{5}{|c|}{ Indicador de Capital Social } \\
\hline Atividade & VI Prudente & Perus & Cid Tiradentes & Parelheiros \\
\hline Conversa com vizinhos & 14 & 13 & 15 & 15 \\
\hline Favores entre vizinhos & 8 & 14 & 16 & 12 \\
\hline $\begin{array}{l}\text { Reuniões para solucionar } \\
\text { problemas }\end{array}$ & 4 & 8 & 8 & 8 \\
\hline Vida social & 88 & 88 & 85 & 66 \\
\hline Total & $\mathbf{1 1 4}$ & $\mathbf{1 2 0}$ & $\mathbf{1 2 4}$ & $\mathbf{1 0 1}$ \\
\hline
\end{tabular}

FONTE: VERÍSSIMO, 2005.

As respostas dos conselheiros de todos os CGS mostraram-se muito próximas neste indicador. Deve-se, contudo, chamar a atenção para uma vida social mais intensa em Perus e Vila Prudente, o que variou o índice total dos conselheiros destes Conselhos para cima. O oposto ocorreu em Parelheiros, onde os conselheiros declararam ter uma vida social mais tacanha em relação aos demais. Em Vila Prudente, apesar de os conselheiros terem dito conversarem com seus vizinhos, quando comparados com os dos outros conselhos afirmaram fazer menos favores uns aos outros.

\footnotetext{
${ }^{42}$ As variações nos valores desta seção oscilam de 0 (zero) a 185 pontos.

${ }^{43}$ Os dados que compõem este indicador, e a possível variação de seus valores, podem ser vistos entre no item VI, no apêndice " $b$ ".
} 
TABELA 6.1: INDICADOR DE CAPITAL SOCIAL, POR PERÍODO DE INÍCIO DE PARTICIPAÇÃO.

\begin{tabular}{|l|c|c|c|}
\hline \multicolumn{4}{|c|}{ Indicador de Capital Social } \\
\hline Atividade & $\begin{array}{c}\text { período } \\
\text { anterior } \\
\text { e/ou até } \\
\mathbf{1 9 8 0}\end{array}$ & $\begin{array}{c}\text { entre 1981 e } \\
\mathbf{1 9 9 2}\end{array}$ & $\begin{array}{c}\text { depois de } \\
\mathbf{2 0 0 1}\end{array}$ \\
\hline Conversa com vizinhos & 19 & 23 & 15 \\
\hline Favores entre vizinhos & 13 & 22 & 11 \\
\hline Reuniões para solucionar problemas & 9 & 11 & 08 \\
\hline Vida social & 88 & 123 & 86 \\
\hline Total & $\mathbf{1 2 9}$ & $\mathbf{1 7 9}$ & $\mathbf{1 2 0}$ \\
\hline
\end{tabular}

FONTE: VERÍSSIMO, 2005.

Ao se olhar para os dados, vê-se que os conselheiros alocados no grupo "depois de 2001" apresentaram indicadores menos expressivos. Mostraram-se, em geral, pessoas que disseram fazer menos favores uns aos outros, conversar menos com seus vizinhos, participar de menos reuniões para solucionar problemas do bairro e ter uma vida social menos ativa.

f) Indicadores de Confiança Generalizada, na polícia e no sistema médico ${ }^{44}$

A questão dos conselheiros de Vila Prudente terem afirmado fazer menos favores entre vizinhos não significa que eles tenham declarado que confiem menos nestes, como mostra a tabela abaixo. Para esta questão da confiança, perguntouse se os conselheiros julgavam que as pessoas do bairro fossem confiáveis, se é comum que se fizessem favores entre vizinhos, e se se podia confiar na maioria das pessoas ou cuidado nunca é demais. Pode-se verificar que os conselheiros de Perus e Cidade Tiradentes apareceram como tendo os menores índices de confiança generalizada, e os conselheiros de Vila Prudente foram os que mais declararam ter confiança generalizada. Estes também julgaram seus vizinhos mais solícitos. ${ }^{45}$

\footnotetext{
${ }^{44}$ As tabelas que originaram os indicadores desta seção podem ser vistas no item VII do apêndice "b".

${ }^{45}$ A variação do indicador de Confiança Generalizada é de 0 a 54 pontos.
} 
TABELA 07: INDICADOR DE CONFIANÇA GENERALIZADA, POR CONSELHO QUE FAZ PARTE.

\begin{tabular}{|l|c|c|c|c|}
\hline \multicolumn{5}{|c|}{ Indicador de confiança generalizada } \\
\hline Medida / Conselho que faz parte & VI Prudente & Perus & $\begin{array}{c}\text { Cid } \\
\text { Tiradentes }\end{array}$ & Parelheiros \\
\hline Confiança nas pessoas do bairro & 9 & 6 & 7 & 8 \\
\hline Avaliação da solicitude dos vizinhos & 9 & 5 & 7 & 7 \\
\hline Confiança generalizada & 2 & 2 & 0 & 2 \\
\hline Total & $\mathbf{2 0}$ & $\mathbf{1 3}$ & $\mathbf{1 4}$ & $\mathbf{1 7}$ \\
\hline
\end{tabular}

FONTE: VERÍSSIMO, 2005.

Nota-se na tabela abaixo que os conselheiros agrupados na categoria dos que iniciaram sua participação recentemente, em 2001, disseram confiar menos nas pessoas de uma maneira geral. Já os que iniciaram sua participação há mais de duas décadas, período anterior e/ou até 1980, afirmaram sentirem-se mais confortáveis no que tange à confiança na maioria das pessoas.

TABELA 7.1: INDICADOR DE CONFIANÇA GENERALIZADA, POR PERÍODO DE INÍCIO DE PARTICIPAÇÃO.

\begin{tabular}{|l|c|c|c|}
\hline \multicolumn{4}{|c|}{ Indicador de confiança generalizada } \\
\hline Medida/Período & $\begin{array}{c}\text { período } \\
\text { anterior e/ou } \\
\text { até 1980 }\end{array}$ & $\begin{array}{c}\text { entre 1981 e e } \\
1992\end{array}$ & $\begin{array}{c}\text { depois de } \\
2001\end{array}$ \\
\hline Confiança nas pessoas do bairro & 10 & 11 & 9 \\
\hline Avaliação da solicitude dos vizinhos & 10 & 11 & 7 \\
\hline Confiança generalizada & 6 & 0 & 0 \\
\hline Total & $\mathbf{2 6}$ & $\mathbf{2 2}$ & $\mathbf{1 6}$ \\
\hline
\end{tabular}

FONTE: VERÍSSIMO, 2005.

Ainda sobre a questão da confiança, quis-se saber dos conselheiros qual a avaliação que eles faziam de algumas instituições públicas. Para tanto, perguntouse se eles se sentiam seguros ao precisarem de policiamento ou atendimento à saúde na região onde moram. Também se questionou a eficiência da Polícia Militar (PM) e do sistema de saúde no que tange à resolução de problemas em suas áreas de competência. Utilizando-se do mesmo método que nas tabelas 
anteriores, apuseram-se valores às respostas dos conselheiros, de maneira que os números das tabelas abaixo indicam mais confiança quanto maiores forem. ${ }^{46}$

Ao se olharem os resultados, percebe-se, em oposição aos dados obtidos em Parelheiros acerca da confiança generalizada, os conselheiros desta região disseram confiar mais nas instituições citadas. Em se tratando do sistema de saúde, à exceção de Perus que avaliou mal a atuação do sistema, esta instituição pública foi mais bem avaliada do que a PM. Isto pode indicar uma ponderação maior no julgamento dos conselheiros em relação às políticas de saúde, por terem se demonstrado mais vinculados a esta.

Também se pode notar que o indicador de "confiança nos médicos" mostrou-se maior do que o da "atuação do sistema de saúde" e da "eficiência das unidades de saúde". Isto pode demonstrar uma avaliação mais positiva da etapa da política pública que para os conselheiros seja mais tangível. Ou seja, o problema não se mostrou ser a atuação dos profissionais de saúde, mas de um sistema, que é impessoal e de difícil personificação.

TABELA 08: INDICADOR DE CONFIANÇA NAS INSTITUIÇÕES MÉDICA E POLICIAL, POR CONSELHO QUE FAZ PARTE. ${ }^{47}$

\begin{tabular}{|l|c|c|c|c|}
\hline \multicolumn{5}{|c|}{ Indicador de Confiança nas Instituições de Políticas Públicas } \\
\hline Instituição / Conselho & VI Prudente & Perus & $\begin{array}{c}\text { Cid } \\
\text { Tiradentes }\end{array}$ & Parelheiros \\
\hline Atuação da PM & 3 & 4 & 3 & 6 \\
\hline Eficiência da PM & 4 & 5 & 4 & 6 \\
\hline Atuação do sistema de saúde & 5 & 2 & 4 & 5 \\
\hline Confiança nos médicos & 8 & 6 & 6 & 7 \\
\hline Eficiência das unidades de saúde & 6 & 5 & 5 & 6 \\
\hline Total & $\mathbf{2 6}$ & $\mathbf{2 2}$ & $\mathbf{2 2}$ & $\mathbf{3 0}$ \\
\hline
\end{tabular}

FONTE: VERÍSSIMO, 2005.

Percebe-se na tabela abaixo o mesmo padrão de avaliação por parte do conjunto dos conselheiros. Aqueles pertencentes ao grupo com menos tempo de

\footnotetext{
${ }^{46}$ Os dados que originaram este indicador estão explícitos na seção VII do segundo apêndice deste trabalho.

${ }^{47} \mathrm{O}$ mínimo possível na pontuação total deste indicador é zero (0). Já o maior indicador possível é 86 pontos.
} 
participação afirmaram confiar menos na eficiência da polícia e do sistema médico do que os que participam há mais tempo.

\section{TABELA 8.1: INDICADOR DE CONFIANÇA NAS INSTITUIÇÕES MÉDICA E POLICIAL, POR PERÍODO DE INÍCIO DE PARTICIPAÇÃO.}

\begin{tabular}{|l|c|c|c|}
\hline \multicolumn{4}{|c|}{ Indicador de Confiança nas Instituições } \\
\hline Medida/Período & $\begin{array}{c}\text { período } \\
\text { anterior e/ou } \\
\text { até 1980 }\end{array}$ & $\begin{array}{c}\text { entre 1981 } \\
\text { e 1992 }\end{array}$ & $\begin{array}{c}\text { depois } \\
\text { de 2001 }\end{array}$ \\
\hline Atuação da PM & 6 & 5 & 5 \\
\hline Eficiência da PM & 5 & 7 & 5 \\
\hline Atuação do sistema de saúde & 7 & 7 & 2 \\
\hline Confiança nos médicos & 10 & 9 & 5 \\
\hline Eficiência das unidades de saúde & 8 & 7 & 7 \\
\hline Total & $\mathbf{3 6}$ & $\mathbf{3 5}$ & $\mathbf{2 4}$ \\
\hline
\end{tabular}

FONTE: VERÍSSIMO, 2005.

ii) Percepções dos conselheiros acerca dos CGS e das diretrizes institucionais do SUS (publicidade, universalidade, integralidade e controle social).

Neste ponto, propôs-se que os conselheiros avaliassem as possibilidades ou dificuldades geradas pela implementação dos Conselhos Gestores de Saúde, como a possibilidade de a população local decidir sobre as obras de saúde, a quantidade e qualidade das prestações de contas das Subprefeituras para a população e a atenção dada às demandas da população.

Na tabela abaixo, nota-se que apenas os conselheiros de Perus apresentaram ter uma avaliação menos positiva da implementação dos CGS como geradores de possibilidades locais. A maioria de seus conselheiros julgou que, nos pontos recém citados, a situação permaneceu a mesma. Já nos demais Conselhos, a 
percepção dos conselheiros foi a de que as possibilidades de fiscalização e decisão sociais aumentaram com a atividade dos Conselhos. ${ }^{48}$

TABELA 09: INDICADOR DE AVALIAÇÃO DOS CGS, POR CONSELHO QUE FAZ PARTE.

\begin{tabular}{|l|c|c|c|c|}
\hline \multicolumn{5}{|c|}{ Avaliação das possibilidades geradas pelos CGS } \\
\hline Categoria & VI Prudente & Perus & Cid Tiradentes & Parelheiros \\
\hline aumentou & 27 & 0 & 27 & 21 \\
\hline Continua igual & 9 & 14 & 2 & 4 \\
\hline Total & $\mathbf{3 3}$ & $\mathbf{1 4}$ & $\mathbf{2 9}$ & $\mathbf{2 5}$ \\
\hline
\end{tabular}

FONTE: VERÍSSIMO, 2005.

Quando foram perguntados sobre a organização do Conselho, se democrática, ou não, em geral os conselheiros julgaram que é democrática, mas, novamente, a avaliação dos membros do Conselho de Perus foi ligeiramente inferior aos demais.

TABELA 10: INDICADOR DE ORGANIZAÇÃO DO CGS, POR CONSELHO QUE FAZ PARTE.

\begin{tabular}{|l|c|c|c|c|}
\hline \multicolumn{5}{|c|}{ Na sua opinião, a organização do CGS tem sido: } \\
\hline $\begin{array}{c}\text { Conselho } \\
\text { que faz } \\
\text { parte }\end{array}$ & $\begin{array}{c}\text { muito } \\
\text { democrática }\end{array}$ & democrática & $\begin{array}{c}\text { pouco } \\
\text { democrática }\end{array}$ & Total \\
\hline $\begin{array}{l}\text { VI } \\
\text { Prudente }\end{array}$ & 1 & 2 & 1 & $\mathbf{8}$ \\
\hline Perus & & 2 & 2 & $\mathbf{6}$ \\
\hline $\begin{array}{l}\text { Cid } \\
\text { Tiradentes }\end{array}$ & & 3 & 1 & $\mathbf{7}$ \\
\hline Parelheiros & 1 & 1 & 2 & $\mathbf{7}$ \\
\hline
\end{tabular}

FONTE: VERÍSSIMO, 2005.

Ao se analisarem estes mesmos dados agregados pelo período de início de participação dos conselheiros, percebe-se que a melhor avaliação das possibilidades geradas pela implementação dos CGS foi feita pelo grupo que iniciou sua participação entre 1981 e 1992. Já a pior avaliação, e seguindo o

\footnotetext{
${ }^{48}$ Os valores das tabelas 09 a 10.2 variam de 0 (zero) a 48 pontos.
} 
padrão dos indicadores anteriores, foi feita pelo grupo que iniciou sua vida associativa mais recentemente, depois de 2001. Para este grupo, como se pode ver na tabela 9.2, as chances da população decidir sobre as obras da saúde, e a prestação de contas das Subprefeituras para a população diminuíram ou permaneceram da mesma maneira após a implementação dos CGS.

\section{TABELA 9.2: INDICADOR DE AVALIAÇÃO DAS POSSIBILIDADES GERADAS PELOS CGS, POR PERÍODO DE INÍCIO DE PARTICIPAÇÃO.}

\begin{tabular}{|l|c|c|c|}
\hline \multicolumn{4}{|c|}{ Avaliação das possibilidades geradas pelos CGS } \\
\hline Categoria & $\begin{array}{c}\text { período } \\
\text { anterior e/ou } \\
\text { até } 1980\end{array}$ & $\begin{array}{c}\text { entre } 1981 \text { e } \\
1992\end{array}$ & $\begin{array}{c}\text { a partir de } \\
2001\end{array}$ \\
\hline aumentou & 27 & 36 & 12 \\
\hline diminuiu & 5 & 3 & 5 \\
\hline continua igual & 4 & 8 & 12 \\
\hline Total & $\mathbf{3 6}$ & $\mathbf{4 7}$ & $\mathbf{2 9}$ \\
\hline
\end{tabular}

FONTE: VERÍSSIMO, 2005.

Em relação à pergunta acerca da organização dos Conselhos, se democrática ou não, vemos na tabela abaixo que, a exemplo da agregação por Conselho de que fazem parte, os períodos de início de participação permaneceram muito próximos entre si em suas avaliações, julgando a organização dos Conselhos, de maneira geral, democráticas. A exceção foi o grupo "entre 1981 e 1992", que apresentou 03 conselheiros que julgaram a organização dos Conselhos pouco democrática.

TABELA 10.2: INDICADOR DE ORGANIZAÇÃO DOS CGS, POR PERÍODO DE INÍCIO DE PARTICIPAÇÃO.

\begin{tabular}{|l|c|c|c|c|}
\hline \multicolumn{5}{|c|}{ Avaliação da organização do CGS } \\
\hline Período & muito democrática & democrática & pouco democrática & Total \\
\hline $\begin{array}{l}\text { período anterior } \\
\text { e/ou até 1980 }\end{array}$ & 1 & 3 & 1 & 10 \\
\hline entre 1981 e 1992 & & 3 & 3 & $\mathbf{9}$ \\
\hline depois de 2001 & 1 & 2 & 2 & $\mathbf{9}$ \\
\hline
\end{tabular}

FONTE: VERÍSSIMO, 2005.

No caso da tabela abaixo as pontuações indicam a somatória do autoposicionamento dos conselheiros (em uma escala de zero a 10) quando se 
questionaram suas avaliações acerca das situações fictícias que se criaram para analisar as percepções deles acerca das diretrizes normativas do SUS (publicidade, universalidade, integralidade e controle social). Por exemplo, se em uma determinada situação um conselheiro se posicionou 01, e três se colocaram na posição 10 da escala, a somatória total deste Conselho, para esta situação foi 31. ${ }^{49}$

Contudo, e diferentemente dos indicadores anteriores, devido à dinâmica desta proposta de metodologia ser mais subjetiva que as demais, ter mais pontuação agregada não significou mais ou menos postura cívico-republicana por parte dos conselheiros.

Analisando-se os dados, percebe-se um padrão bastante acurado de conhecimento sobre o sistema de saúde por parte dos entrevistados. Na primeira estória (do paciente que foi vítima de negligência médica e foi encaminhado para tratamento na cidade vizinha), vê-se que os conselheiros discordaram da peregrinação do paciente para obter atendimento. Contudo, opinaram que se o município não tinha hospital, o melhor foi ter encaminhado o paciente para a cidade vizinha, uma vez que o SUS tem caráter universal. ${ }^{50}$

É visível que todos os conselheiros demonstraram a força da idéia das possibilidades geradas pela participação ao terem afirmado que a população da pequena cidade deveria reivindicar um hospital.

\footnotetext{
${ }^{49}$ Os resultados destas tabelas, quando agregados por Conselho do qual o conselheiro faz parte apresentaram um valor mínimo de 04 e máximo de 40 pontos. Já quando agregados por período de início de participação, os valores variaram entre 5 e 60 pontos.

${ }_{50}$ Muitos conselheiros explanaram o fato de que um hospital deve ser construído para cada 200.000 habitantes.
} 
TABELA 11: INDICADOR DE JULGAMENTO CÍVICO-REPUBLICANO (CASO E.1), POR CONSELHO QUE FAZ PARTE.

\begin{tabular}{|l|c|c|c|c|}
\hline \multicolumn{5}{|c|}{ Tratamento em outra cidade - E.1 } \\
\hline Avaliação / Conselho que faz parte & VI. Prudente & Perus & $\begin{array}{c}\text { Cid. } \\
\text { Tiradentes }\end{array}$ & Parelheiros \\
\hline 1- Prefeitura agiu corretamente & 20 & 13 & 10 & 20 \\
\hline 2 - Prefeitura agiu de maneira errada & 25 & 30 & 35 & 18 \\
\hline 3 - hospital da cidade não deveria receber & 11 & 17 & 26 & 12 \\
\hline $\begin{array}{l}4 \text { - moradores cidadezinha deveriam } \\
\text { reivindicar hospital }\end{array}$ & 35 & 39 & 35 & 29 \\
\hline $\begin{array}{l}\text { 5 - moradores da capital deveriam se unir } \\
\text { para impedir vinda de pacientes de outra } \\
\text { cidade }\end{array}$ & 4 & 22 & 31 & 6 \\
\hline
\end{tabular}

FONTE: VERÍSSIMO, 2005.

Os padrões de respostas, ao se agregarem os conselheiros por período de início de participação, permaneceram muito similares entre si, não apresentando variações muito acentuadas. Percebe-se o fator da força do ideário da participação como veículo de aquisição de serviços de saúde, principalmente nos conselheiros que iniciaram sua participação depois de 2001 - item 04 da tabela. Contudo, esta inclinação participacionista apareceu mesmo quando a participação poderia significar a restrição da universalidade do atendimento, como foi o caso deste grupo (depois de 2001) ter demonstrado essa inclinação quando declarou que os "moradores da capital deveriam se unir para impedir a vinda de pacientes de outras cidades" (item 05). 
TABELA 11.1: INDICADOR DE JULGAMENTO CÍVICO-REPUBLICANO (CASO E.1), POR PERÍODO DE INÍCIO DE PARTICIPAÇÃO. ${ }^{51}$

\begin{tabular}{|l|c|c|c|}
\hline \multicolumn{4}{|c|}{ Tratamento em outra cidade - E.1 } \\
\hline Avaliação & $\begin{array}{c}\text { período } \\
\text { anterior } \\
\text { e/ou até } \\
1980\end{array}$ & $\begin{array}{c}\text { entre 1981 } \\
\text { e 1992 }\end{array}$ & $\begin{array}{c}\text { depois de } \\
2001\end{array}$ \\
\hline $\begin{array}{l}\text { 1 - Prefeitura agiu } \\
\text { corretamente }\end{array}$ & 26 & 23 & 14 \\
\hline $\begin{array}{l}2 \text { - Prefeitura agiu de } \\
\text { maneira errada }\end{array}$ & 18 & 41 & 41 \\
\hline $\begin{array}{l}3 \text { - Hospital da cidade } \\
\text { não deveria receber }\end{array}$ & 18 & 22 & 26 \\
\hline $\begin{array}{l}4-\text { Moradores } \\
\text { cidadezinha deveriam } \\
\text { reivindicar hospital }\end{array}$ & 41 & 52 & 45 \\
\hline $\begin{array}{l}5 \text { - Moradores da capital } \\
\text { deveriam se unir para } \\
\text { impedir vinda de } \\
\text { pacientes de outra } \\
\text { cidade }\end{array}$ & 9 & 12 & 32 \\
\hline
\end{tabular}

FONTE: VERÍSSIMO, 2005.

A segunda situação proposta para análise (que narrou a estória de um município onde o atendimento à saúde corria dentro de todos os padrões de excelência, até o acampamento de centenas de Sem Terra na região), demonstrou bem o ethos dos conselheiros em relação à participação e à reivindicação. De maneira geral eles discordaram que os Sem Terra não devessem ser atendidos, tendo achado que eles deveriam ter sido acolhidos de qualquer maneira. Mas quando se mencionou a questão da reivindicação, seja a ida do MST ao CMS, ou a ida dos três "segmentos" (Prefeitura, Conselho e MST) ao governo do Estado (alternativas 4 e 5), as pontuações também cresceram muito ${ }^{52}$.

\footnotetext{
${ }^{51}$ Neste caso de agregação dos dados (por período de início de participação), a maior pontuação de um grupo é de 60 pontos e a menor de cinco.

52 Lembro que dada a escala de 01 a 10, e a quantidade de 04 conselheiros por Conselho que faz parte, a maior situação de discordância pontua 04, e a maior de concordância pontua 40.
} 
Isto não indicou necessariamente que os conselheiros foram contrários ao atendimento dos Sem Terra, mas, antes, que se posicionaram a favor de um processo reivindicatório, prática que se verificou muito forte em seus espectros.

\section{TABELA 12: INDICADOR DE JULGAMENTO CÍVICO-REPUBLICANO (CASO E.3), POR CONSELHO QUE FAZ PARTE.}

\begin{tabular}{|l|c|c|c|c|}
\hline \multicolumn{5}{|c|}{ Atendimento aos Sem Terra - E.3 } \\
\hline Avaliação & $\begin{array}{c}\text { Vl. } \\
\text { Prudente }\end{array}$ & Perus & $\begin{array}{c}\text { Cid. } \\
\text { Tiradentes }\end{array}$ & Parelheiros \\
\hline $\begin{array}{l}\text { 1 - Atitude correta, quem paga } \\
\text { imposto tem prioridade no } \\
\text { atendimento }\end{array}$ & 15 & 13 & 7 & 4 \\
\hline $\begin{array}{l}\text { 2 - Sem Terra deveriam } \\
\text { reivindicar verbas para governo } \\
\text { do Estado }\end{array}$ & 22 & 31 & 23 & 10 \\
\hline $\begin{array}{l}3 \text { - Deveriam ter sido atendidos } \\
\text { de qualquer maneira }\end{array}$ & 36 & 38 & 32 & 36 \\
\hline $\begin{array}{l}4 \text { - Deveriam ir ao CMS requerer } \\
\text { atendimento }\end{array}$ & 33 & 26 & 37 & 34 \\
\hline $\begin{array}{l}\text { 5 - CMS, MST e PM deveriam } \\
\text { requerer verbas para governo do } \\
\text { Estado, para depois atenderem } \\
\text { os ST }\end{array}$ & 31 & 26 & 29 & 22 \\
\hline
\end{tabular}

FONTE: VERÍSSIMO, 2005.

Olhando-se os dados agregados por período de início de participação, percebe-se um posicionamento mais exclusivista dos conselheiros que iniciaram sua participação depois de 2001 em relação à situação. Estes julgaram, de maneira geral, que os Sem Terra deveriam ser atendidos após haver verba para esse atendimento. $\mathrm{O}$ caráter de reivindicação social também aparece com muita força nesta questão, quando os conselheiros afirmaram (à exceção do grupo "período anterior e/ou até 1980") que os Sem Terra deveriam reivindicar verbas para o governo do Estado, e que eles deveriam reivindicar atendimento no Conselho Municipal de Saúde (questões 02 e 04 da tabela abaixo). 
TABELA 12.1: INDICADOR DE JULGAMENTO CÍVICO-REPUBLICANO (CASO E.3), POR PERÍODO DE INÍCIO DE PARTICIPAÇÃO.

\begin{tabular}{|l|c|c|c|}
\hline \multicolumn{3}{|c|}{ Atendimento aos Sem Terra - E.3 } \\
\hline Avaliação & $\begin{array}{c}\text { período } \\
\text { anterior } \\
\text { e/ou até } \\
1980\end{array}$ & $\begin{array}{c}\text { entre 1981 } \\
\text { e 1992 }\end{array}$ & $\begin{array}{c}\text { depois de } \\
2001\end{array}$ \\
\hline $\begin{array}{l}1 \text { - Atitude correta, quem } \\
\text { paga imposto tem } \\
\text { prioridade no } \\
\text { atendimento }\end{array}$ & 16 & 10 & 18 \\
\hline $\begin{array}{l}2 \text { - Sem Terra deveriam } \\
\text { reivindicar verbas para } \\
\text { gov do Estado }\end{array}$ & 17 & 30 & 39 \\
\hline $\begin{array}{l}3 \text { - Deveriam ter sido } \\
\text { atendidos de qualquer } \\
\text { maneira }\end{array}$ & 41 & 55 & 38 \\
\hline $\begin{array}{l}4-\text { Deveriam ir ao CMS } \\
\text { requerer atendimento }\end{array}$ & 33 & 51 & 46 \\
\hline $\begin{array}{l}5-\text { CMS, MST e PM } \\
\text { deveria requerer verbas } \\
\text { para governo do Estado, } \\
\text { para depois atenderem } \\
\text { os ST }\end{array}$ & 32 & 31 & 45 \\
\hline
\end{tabular}

FONTE: VERÍSSIMO, 2005.

O último estímulo dado aos conselheiros narra a estória de um conselheiro que solicitou ao Conselho sobras de material de uma obra de um posto de saúde e obteve autorização para pegá-los.

Percebe-se que os conselheiros foram muito coerentes ao pensarem a coisa pública. Afirmaram, em sua maioria, serem contrários ao conselheiro ter podido pegar o material de qualquer maneira (item 2). Contudo, mais uma vez, o espírito participacionista os pregou uma peça, e pode-se ver que, excetuando-se os conselheiros de Vila Prudente, a tendência de se julgar que este material pudesse ter sido doado a algum movimento de moradia mostrou-se muito forte (item 3 ). 
Mais forte, em praticamente todos os Conselhos, foi o posicionamento de poder executivo que declararam ter os conselheiros ao terem concordado que 0 conselheiro tenha ido pedir permissão ao Conselho antes de pegar o material de construção (item 1).

TABELA 13: INDICADOR DE JULGAMENTO CÍVICO-REPUBLICANO (CASO E.4), POR CONSELHO QUE FAZ PARTE.

\begin{tabular}{|c|c|c|c|c|}
\hline \multicolumn{5}{|c|}{ Doação privada de material público- E. 4} \\
\hline Avaliação & VI. Prudente & Perus & Cid. Tiradentes & Parelheiros \\
\hline $\begin{array}{l}1 \text { - Fez bem ao } \\
\text { pedir, o CMS é } \\
\text { soberano }\end{array}$ & 33 & 22 & 21 & 25 \\
\hline $\begin{array}{l}2 \text { - Poderia } \\
\text { pegar de } \\
\text { qualquer } \\
\text { maneira, o } \\
\text { material sobrou }\end{array}$ & 4 & 4 & 4 & 6 \\
\hline $\begin{array}{l}3 \text { - Deveria ter } \\
\text { dado a algum } \\
\text { Movimento de } \\
\text { Moradia }\end{array}$ & 13 & 22 & 27 & 31 \\
\hline $\begin{array}{l}4 \text { - CMS não tem } \\
\text { autoridade, } \\
\text { deveria ter } \\
\text { pedido } \\
\text { sindicância para } \\
\text { apurar a sobra } \\
\text { de materiais }\end{array}$ & 36 & 24 & 32 & 37 \\
\hline
\end{tabular}

FONTE: VERÍSSIMO, 2005.

Agregando-se os conselheiros por período de início de participação, repetiram-se os padrões de respostas da tabela anterior. Duas distinções se fizeram notar, contudo: o grupo que iniciou sua participação no período anterior e/ou até 1980 foi contrário à idéia de que o conselheiro fez bem ao pedir o material para o Conselho. O segundo ponto que se deve chamar atenção diz respeito ao grupo que iniciou sua vida associativa depois de 2001: estes conselheiros mostraram-se intensamente contrários à proposição de que se doasse este material para um movimento de moradia. 
TABELA 13.1: INDICADOR DE JULGAMENTO CÍVICO-REPUBLICANO (CASO E.4), POR PERÍODO DE INÍCIO DE PARTICIPAÇÃO.

\begin{tabular}{|l|c|c|c|}
\hline \multicolumn{4}{|c|}{ Doação privada de material público- E. 4 } \\
\hline Avaliação & $\begin{array}{c}\text { período } \\
\text { anterior e/ou } \\
\text { até 1980 }\end{array}$ & $\begin{array}{c}\text { entre 1981 } \\
\text { e 1992 }\end{array}$ & $\begin{array}{c}\text { depois de } \\
2001\end{array}$ \\
\hline $\begin{array}{l}\text { 1 - Fez bem ao pedir, o } \\
\text { CMS é soberano }\end{array}$ & 16 & 25 & 32 \\
\hline $\begin{array}{l}\text { 2 - Poderia pegar de } \\
\text { qualquer maneira, o } \\
\text { material sobrou }\end{array}$ & 6 & 6 & 5 \\
\hline $\begin{array}{l}\text { 3 - Deveria ter dado a } \\
\text { algum Movimento de } \\
\text { Moradia }\end{array}$ & 46 & 35 & 13 \\
\hline $\begin{array}{l}4-\text { CMS não tem } \\
\text { autoridade, deveria ter } \\
\text { pedido sindicância para } \\
\text { apurar a sobra de } \\
\text { materiais }\end{array}$ & 40 & 50 & 39 \\
\hline
\end{tabular}

FONTE: VERÍSSIMO, 2005. 


\section{1 - Considerações finais}

$\mathrm{Na}$ tabela abaixo se apresentam os dados dos resultados obtidos pelos conselheiros, agregados por Conselhos, nos indicadores que se discutiram até então:

TABELA 14: COMPARAÇÃO ENTRE OS INDICADORES DE CULTURA CÍVICA E CAPITAL SOCIAL, POR CONSELHO QUE FAZ PARTE.

\begin{tabular}{|l|c|c|c|c|}
\hline \multicolumn{5}{|c|}{ Comparação entre os Indicadores } \\
\hline \multirow{2}{*}{ Indicador } & VP & $P e$ & $C T$ & $P a$ \\
\hline Informação Geral & 41 & 47 & 43 & 33 \\
\hline Informação Política & 35 & 29 & 34 & 44 \\
\hline Valores Sócio-Políticos & 41 & 42 & 48 & 45 \\
\hline $\begin{array}{l}\text { Participação e } \\
\text { Associativismo }\end{array}$ & 55 & 74 & 81 & 78 \\
\hline Tolerância & 46 & 51 & 34 & 34 \\
\hline Capital Social & 114 & 120 & 124 & 101 \\
\hline Confiança Generalizada & 20 & 13 & 14 & 17 \\
\hline $\begin{array}{l}\text { Confiança na polícia e } \\
\text { sistema médico }\end{array}$ & 26 & 22 & 22 & 30 \\
\hline $\begin{array}{l}\text { Possibilidades Geradas } \\
\text { pelos CGS }\end{array}$ & 33 & 14 & 29 & 25 \\
\hline Organização dos CGS & 8 & 6 & 7 & 7 \\
\hline Total & 423 & 442 & 457 & 433 \\
\hline Indicador 53 & $\mathbf{0 , 0 0}$ & $\mathbf{0 , 5 6}$ & $\mathbf{1 , 0 0}$ & $\mathbf{0 , 2 9}$ \\
\hline
\end{tabular}

FONTE: VERISSSIMO, J. 2005.

Pôde-se perceber no andamento da análise dos dados que quando as respostas dos conselheiros foram agregadas por Conselho não houve um padrão de

\footnotetext{
${ }^{53} \mathrm{O}$ cálculo que se utilizou para a confecção deste indicador foi o mesmo que se usou para os demais índices deste trabalho: (VO-mvc) / (Mvc-mvc).
} 
diferenciação nítido que se permitisse aferir uma conclusão. Ao olhar-se para os indicadores mais baixos, por exemplo, percebe-se que ao se falar de instrução geral os conselheiros de Parelheiros obtiveram o menor índice, 33. Já ao se tratar de informação política, estes mesmos conselheiros detiveram o indicador mais elevado, 44 pontos, e os de Perus o pior, 29.

Os indicadores dos Valores Sócio-Políticos e de Associativismo tiveram uma relação entre si, pois Cidade Tiradentes, a região detentora do mais alto valor no primeiro, 48, também tem o mais elevado valor no segundo, 81. Esta associação também ocorreu nos demais Conselhos: Parelheiros obteve 45 e 78, respectivamente; Perus 42 e 74; e em Vila Prudente os conselheiros demonstraram estes indicadores mais baixos, 41 pontos e 55 . Isto leva a se concluir que os conselheiros que participaram mais de atividades associativas tendem a ter valores mais democráticos, a terem mais orgulho nacional e serem politicamente mais ativos.

Esta relação se esvaiu ao tratarem-se os dados de tolerância e capital social. Os conselheiros mais democráticos e participativos não foram, necessariamente, os mais tolerantes e com mais capital social. Neste ponto, os conselheiros de Perus apresentaram-se os mais tolerantes (51), e os de Cidade Tiradentes os que tiveram mais capital social (124).

Tratando de Confiança Generalizada e Confiança nas Instituições Médica e Policial, nota-se que Vila Prudente demonstrou ter mais confiança generalizada (20), enquanto Parelheiros apareceu como tendo mais confiança nas instituições que citamos (30). Mas ter muita confiança na polícia e no sistema médico não demonstrou ter relação com a avaliação que os conselheiros fizeram das possibilidades geradas pela implementação dos Conselhos. Neste ponto, os conselheiros de Vila Prudente foram os que melhor avaliaram as possibilidades geradas pela implementação dos CGS: obtiveram 33 pontos, oito pontos a mais do que Parelheiros (25), região na qual os conselheiros melhor avaliaram a polícia e o sistema médico. Contudo, estes se posicionaram 11 pontos distantes daqueles que pior avaliaram estas possibilidades, os conselheiros de Perus (14). 
Sobre as opiniões atribuídas pelos conselheiros acerca do grau de democratização na organização dos Conselhos, houve uma relação entre os que viram mais possibilidades trazidas pela implantação dos CGS e aqueles que acharam os Conselhos mais democráticos. Os conselheiros de Vila Prudente foram os que melhor avaliaram este quesito (08), e os que pior o fizeram foram os de Perus (06).

Em se tratando das avaliações situacionais às quais os conselheiros foram submetidos, baseados nas estórias que Ihes foram contadas, os conselheiros de Parelheiros se mostraram mais atentos às diretrizes de universalidade e integralidade do SUS (tabelas 11 e 12). Contudo, foram os que mais se distanciaram da diretriz do controle social, ao julgarem as atividades do Conselho soberanas a ponto de terem a prerrogativa de doarem materiais de obras públicas (tabela 13).

Como se vê pelos dados da tabela abaixo, não há relação entre ser conselheiro do Conselho Gestor de Saúde que obteve os posicionamentos mais altos nos Índice de Institucionalidade e apresentar os indicadores mais elevados em seus perfis de cultura cívica e intensidade de capital social.

\section{TABELA 15: VERIFICAÇÃO DA RELAÇÃO ENTRE OS INDÍCES DE INTITUCIONALIDADE DOS CONSELHOS COM O INDICADOR DE COMPORTAMENTO POLÍTICO DOS CONSELHEIROS, 2005.}

\begin{tabular}{|l|c|c|c|}
\hline \multicolumn{4}{|c|}{ CONSELHOS SELECIONADOS } \\
\hline Conselhos de que fazem parte & IDH-M & IInst & $\begin{array}{c}\text { Comportamento } \\
\text { político }\end{array}$ \\
\hline Cidade Tiradentes & 0,672 & 0,61 & 1,00 \\
\hline Parelheiros & 0,650 & 0,84 & 0,29 \\
\hline Perus & 0,698 & 0,70 & 0,56 \\
\hline VI Prudente/Sapopemba & 0,699 & 0,42 & 0,00 \\
\hline FONTE: PEDROSOS, M. 2001; Banco de dados CEBRAPIIDS. 2004, PMSP/SMS, 2003 e VERISSIMO, J. \\
\hline
\end{tabular}
2005.

Como se fez notar, o Conselho de Cidade Tiradentes apresentou o maior índice de cultura cívica e capital social entre seus conselheiros, a despeito de ter um 
baixo Índice de Institucionalidade. O Conselho de Perus, que apresentou o índice de institucionalidade acima da mediana $(0,70)$, atingiu o segundo mais alto indicador de cultura cívica entre seus conselheiros. Parelheiros, que deteve o maior resultado do Índice de Institucionalidade, apresentou o terceiro maior grau de cultura cívica entre seus conselheiros.

Contudo, ao agregarem-se os dados em grupos por tempo pregresso de participação, percebe-se na tabela abaixo, ao se olhar para os 10 indicadores que se construíram ao longo desta seção, uma forte associação entre o período de início de participação do conselheiro e seu perfil de comportamento, valores e atitudes políticas.

TABELA 14.1: COMPARAÇÃO ENTRE OS INDICADORES, POR PERÍODO DE INÍCIO DE PARTICIPAÇÃO.

\begin{tabular}{|c|c|c|c|}
\hline \multicolumn{4}{|c|}{ Comparação entre os Indicadores } \\
\hline \multirow[b]{2}{*}{ Indicador } & \multicolumn{3}{|c|}{ Período de início de Participação } \\
\hline & $\begin{array}{c}\text { período anterior e/ou } \\
\text { até } 1980\end{array}$ & entre 1981 e 1992 & a partir 2001 \\
\hline Informação Geral & 45 & 65 & 54 \\
\hline Informação Política & 53 & 62 & 26 \\
\hline $\begin{array}{l}\text { Valores Sócio- } \\
\text { Políticos }\end{array}$ & 56 & 77 & 43 \\
\hline $\begin{array}{l}\text { Participação e } \\
\text { Associativismo }\end{array}$ & 121 & 144 & 37 \\
\hline Tolerância & 34 & 52 & 59 \\
\hline Capital Social & 129 & 179 & 120 \\
\hline $\begin{array}{l}\text { Confiança } \\
\text { Generalizada }\end{array}$ & 26 & 22 & 16 \\
\hline $\begin{array}{l}\text { Confiança nas } \\
\text { Instituições }\end{array}$ & 36 & 35 & 24 \\
\hline $\begin{array}{l}\text { Possibilidades } \\
\text { Geradas pelos CGS }\end{array}$ & 36 & 47 & 29 \\
\hline $\begin{array}{l}\text { Organização dos } \\
\text { CGS }\end{array}$ & 10 & 9 & 9 \\
\hline Total & 562 & 712 & 428 \\
\hline Indicador & 0,47 & 1,00 & 0,00 \\
\hline
\end{tabular}

FONTE: VERISSIMO, 2005. 
O grupo de conselheiros que iniciou sua participação depois de 2001 apresentou os menores resultados em 08 dos 10 indicadores. ${ }^{54}$ Ao se observar com cautela, percebe-se que este grupo apresentou o valor mais alto apenas no indicador "Tolerância". Assim, o Indicador de Cultura Cívica destes conselheiros apresentouse como sendo o mais baixo: 0,00 .

Em oposição está o grupo que iniciou sua participação entre os anos de 1981 e 1992, que apresentou os melhores indicadores em 06 dos 10 construídos. $^{55}$ Talvez isto possa ser justificado pelo fato desta coorte ter iniciado suas atividades associativas em franco período de reabertura política, o que justificaria terem demonstrado maior interesse por informações políticas, mais inclinados para valores democráticos e, por participarem há mais tempo, tiveram oportunidades de terem tomado parte em mais associações. Já a sua melhor avaliação em relação à organização dos Conselhos pode ser explicada pelo fato de estes conselheiros terem feito parte de movimentos populares antes da implementação do Sistema Único de Saúde, e a existência dos Conselhos ser uma reivindicação antiga destes movimentos.

Outro traço do grupo "depois de 2001" pode ser visto na avaliação que fizeram acerca das diretrizes normativas do SUS. Apesar do forte crédito que depositaram em atividades de reivindicações públicas (tabela 11.1, E.1, item 4 e tabela 12.1, E.3, itens 2 e 5), demonstraram forte caráter privatista e localista, (tabela 11.1, E.1, itens 4 e 5; e tabela 12.1, E.3, itens 1 e 2), além de terem demonstrado um entendimento super-dimensionado das atribuições dos Conselhos (Tabela 13.1, E.4, item 1; e 12.1, E.3, item 4).

\footnotetext{
${ }^{54}$ Os indicadores são: Informação Política, Valores Sócio-Políticos, Participação e Associativismo, Capital Social, Confiança Geral e nas Instituições Médica e Policial, Possibilidades Geradas pelos CGS, e organização dos CGS.

${ }_{55}$ Informação Geral e Política, Valores Sócio-Políticos, Participação e Associativismo, Capital Social e Possibilidades Geradas pelos CGS, são os indicadores.
} 
À guisa de conclusão - e lembrando que esta pesquisa é um estudo experimental, que antes de qualquer outra coisa visou a levantar indícios acerca dos debates entre instituições, capital social e cultura cívica -, pode-se relevar a hipótese de que o capital e a cultura cívica dos conselheiros tenham sido atributos gerados e fortalecidos pelo seu tempo pregresso de participação.

Como se viu, ao se apresentarem os dados não houve relação significativa entre o perfil de cultura política dos conselheiros e o desenho institucional dos Conselhos. Como demonstraram os dados, os conselheiros do Conselho de Cidade Tiradentes, com o segundo mais baixo Índice de Institucionalidade, apresentaram comportamentos, valores e atitudes mais democráticas e cívicas, bem como mais capital social, em relação aos conselheiros dos demais Conselhos. Já os conselheiros do Conselho de Parelheiros (Conselho que detém o mais elevado índice de Institucionalidade) apresentaram o segundo pior indicador de comportamento político, tendo demonstrado ser os conselheiros menos tolerantes, e com menos informação geral e capital social.

Todavia, houve clara associação entre o período de início de participação do conselheiro e seu comportamento político. O grupo de conselheiros que demonstrou o maior índice de cultura cívica, capital social, informação política e valores democráticos, foi aquele que iniciou suas atividades participativas no advento da abertura política e consolidação democrática (grupo "entre 1981 e 1992"). Por terem mais tempo de participação do que o grupo que iniciou suas atividades associativas a partir do ano de 2001, os conselheiros daquele grupo se mostraram mais entusiasmados com as possibilidades geradas pelos Conselhos; com valores democráticos mais arraigados; com redes de capital social mais amplas e com uma vida associativa e social mais intensas. 


\section{Capítulo V - Comunidade e democracia.}

Como se pôde perceber pela análise dos dados, houve relação entre aprimoramento de cultura cívica, capital social, práticas e valores democráticos, e um aperfeiçoamento da percepção cívico-republicana do bem público, em função do tempo de participação dos conselheiros em diversas organizações associativas.

Contudo, e como evidenciaram os dados, não houve associação entre este ou aquele desenho institucional dos Conselhos dos quais os conselheiros fazem parte e seu perfil de valores, práticas e percepções acerca da democracia.

Para verificar-se esta relação, levou-se em consideração, em se tratando dos Conselhos, sua organização burocrática, o grau de empenho do gestor com a operacionalização dos diversos Conselhos, os instrumentos de publicização destes fóruns e a porcentagem de ocupação dos assentos destinadas à sociedade civil nestes espaços. ${ }^{56}$

Desta perspectiva, vê-se que os Conselhos de Parelheiros e Perus mostraram-se os mais institucionalizados (os quais obtiveram 0,84 e 0,70 ponto no índice de Institucionalidade, respectivamente), em oposição aos Conselhos de Cidade Tiradentes e Vila Prudente $(0,61$ e 0,42). Assim, pode-se afirmar que os dois primeiros Conselhos demonstraram ser burocraticamente melhor organizados; deterem mais empenho do gestor com a operacionalização de seus espaços; possuírem mais variedade de relações institucionais e meios de divulgação de suas atividades e resoluções, bem como terem as 24 cadeiras destinadas à sociedade civil ocupadas.

Visando a aferição de valores, práticas e comportamentos democráticos dos conselheiros, construíram-se alguns indicadores: Informação Geral e Política, Valores Sócio-políticos, Participação e Associativismo, Tolerância, Capital Social,

\footnotetext{
${ }^{56}$ Para detalhes sobre as variáveis utilizadas para estas seleções ver apêndice "a".
} 
Confiança Generalizada, na polícia e sistema médico, Possibilidades geradas pelos CGS e Organização dos Conselhos.

Como se discutiu no primeiro capítulo deste trabalho, as orientações políticas das pessoas podem ser internalizadas em suas relações com as instituições. Desta perspectiva, qualidades substantivas inerentes às instituições determinam os recursos morais e cognitivos das pessoas, fomentando o comprometimento individual - este baseado na antecipação que o ator político faz de que os demais participantes de determinada instituição também se sintam comprometidos a compartilhar os mesmos valores.

Esperava-se, desta forma, que os indicadores de orientações políticas medidos entre os conselheiros dos Conselhos que apresentaram os melhores indicadores de institucionalidade também se tivessem demonstrado elevados. Contudo, ao se analisarem os dados, o que se viu foi que os conselheiros do Conselho de Parelheiros (que detém o melhor Índice de Institucionalidade) apresentaram apenas três indicadores, dentre dez, acima dos outros três Conselhos (Informação Política, Participação e Associativismo e Confiança na polícia e sistema médico). Os conselheiros do segundo Conselho com o maior Índice de Institucionalidade, Perus, demonstraram apenas 02 indicadores (Informação Geral e Tolerância) mais elevados que o Conselho de Cidade Tiradentes, este com a terceira melhor colocação institucional. Os conselheiros deste Conselho, por sua vez, apresentaram 04 indicadores (Informação Geral, Valores Sócio-Políticos, Participação e Associativismo e Capital Social) acima dos conselheiros do quarto Conselho no Índice de Institucionalidade, Vila Prudente.

Dadas estas evidências, volto à hipótese complementar deste trabalho: os valores, percepções e atitudes políticas dos conselheiros variam de acordo com seu período de tempo de participação.

Desta perspectiva (quando foram agregados por tempo de início de participação dos conselheiros), os dados desta pesquisa mostraram-se relevantes. Como se demonstrou no capítulo 04, o grupo de conselheiros que iniciou suas atividades 
participativas depois de 2001 apresentou os mais baixos indicadores de comportamentos, valores e atitudes democráticas (08 dos 10 indicadores construídos). Também se observou pelos dados que o grupo que iniciou sua participação entre 1981 e 1992 apresentou 06 dos 10 indicadores acima dos demais grupos.

Pode-se discutir estas evidências empíricas pela perspectiva teórica de que para se falar em comportamento político, deve-se apreciar os processos de formação social dos quais as pessoas fizeram parte em suas sociedades. Desta perspectiva, grandes estudos como o caso da Itália (estudado por Putnam) e da Inglaterra (estudado por Almond e Verba) mereceram destaque no primeiro capítulo deste trabalho (Putnam, 2001; Almond e Verba, 1963).

Contudo, e reforçando a crítica de que os resultados destes trabalhos podem ser lidos como eurocêntricos, deterministas e anacrônicos, verificou-se, nesta pesquisa, que a cultura política das pessoas modificou-se de acordo com o período de início de participação e deliberação populares dos conselheiros.

Como se viu no terceiro capítulo, o período, "entre 1981 e 1992" foi de grande efervescência social e conquistas democráticas. Em oposição, o grupo "depois de 2001" tem por característica ter iniciado suas atividades participacionistas em um período de expansão de instituições híbridas entre sociedade civil e Estado (como os CGS, por exemplo). Isto gerou tensões e controvérsias acerca do modus operandi de como os movimentos sociais (anteriormente independentes e questionadores das ações do Estado) se apoderariam deste novo cenário.

Discutiu-se no segundo capítulo o ethos que permeia as atividades dos Conselhos Gestores de Saúde: são espaços que visam a possibilitar a negociação entre governo, prestadores de serviços e sociedade civil em relação à suas diversas propostas de direcionamento dos recursos da saúde. Esta presença da sociedade no direcionamento das políticas de saúde também proporcionaria a possibilidade da fiscalização da eficiência e eficácia das diretrizes de políticas públicas estabelecidas. 
Desta perspectiva, pode-se aproximar o ideário destes Conselhos das premissas normativas da escola da democracia participacionista. A partir desta concepção, pode-se deduzir que os Conselhos visam à diminuição de desigualdades sociais via participação popular nos processos decisórios.

Contudo, a participação, não apenas nestes fóruns, mas como em diversos tipos de organizações participativas, permite uma interação face-a-face entre as pessoas, através da qual os indivíduos podem interagir uns com os outros, debatendo as decisões tomadas pelas autoridades políticas, bem como 0 conteúdo moral das diferentes relações que existem no âmbito social.

Desta perspectiva deliberacionista, ao participarem nestas instituições, as pessoas deliberam acerca de questões políticas, e adotam estratégias para tornar as autoridades políticas sensíveis a suas demandas. Esta dinâmica estabelece uma relação entre participação e argumentação públicas, que se institucionaliza nas redes de comunicação dos espaços público-políticos dos quais os conselheiros fizeram parte desde o início de suas atividades participacionistas.

Assim, quando se demonstrou no capítulo 03 que os conselheiros que iniciaram sua participação entre 1981 e 1992 (em relação ao grupo que iniciou suas atividades participacionistas depois de 2001), participaram de mais reuniões comunitárias para solucionarem problemas do bairro; que eles visitaram mais os amigos e parentes e que fazem parte de mais associações, está-se assumindo que estas pessoas deliberaram mais acerca da coisa pública.

\section{Trajetórias}

Partindo desta premissa, pode-se confirmar os dados da pesquisa a partir das histórias associativas dos conselheiros, que demonstraram que aqueles dos grupos "anterior e/ou até 1980" e "entre 1981 e 1992" se envolveram na vida participativa muito antes do advento dos Conselhos. É o caso de alguns deles que se engajaram inicialmente nos movimentos reivindicatórios da Igreja Católica, 
como as Pastorais e as CEBs. Em alguns casos, no bojo da reabertura política, engajaram-se na fundação do Partido dos Trabalhadores. Estes conselheiros, já no primeiro governo petista na capital paulista (1989-1992), participaram das primeiras experiências dos Conselhos de Saúde. Em um destes casos, o conselheiro participou da fundação das CEBs e do PT, e depois fez parte do PMDB e o PSDB.

Em outros casos, os sindicatos desempenharam importante papel no início das atividades de alguns conselheiros. Em um caso específico, o conselheiro envolveu-se com o Movimento Popular de Saúde porque suas reuniões aconteciam no espaço do Sindicato dos Trabalhadores da Indústria Têxtil, do qual ele fazia parte. Daí para os CGS foi uma questão de tempo. Já a aliança entre o Sindicato dos Trabalhadores da Indústria de Cimento e Cal e o Movimento de Saúde se deu pelo fato de o trabalho destes operários ser bastante deletério à saúde, e estes trabalhadores reivindicarem atendimento à saúde específico devido a suas atividades.

O vínculo entre as Associações de Bairro e o Movimento de Saúde se deu praticamente em suas origens, uma vez que as reivindicações por benfeitorias de saúde eram tratadas pelos participantes destas associações conjuntamente com as discussões por saneamento básico, asfaltamento, moradia, entre outras.

A própria deficiência física foi a motivação de outro conselheiro. Em 1981, para melhor compreender suas limitações, e reivindicar melhores condições de locomoção e de atendimento à saúde, ele se filiou ao movimento da pessoa deficiente. No processo participativo se vinculou ao PT, e chegou aos Conselhos.

Já no grupo "depois de 2001", os conselheiros iniciaram suas atividades participacionistas com os Conselhos de Saúde ou no Orçamento Participativo.

As motivações de ingresso na vida participacionista, nos três grupos, mostraramse diversas, e a primeira motivação dos conselheiros demonstrou-se ser um cálculo de que participando poderiam melhorar suas condições de saúde. 
Contudo, aparentemente há indicações de que possa ter havido mudanças nos valores, percepções e práticas democráticas destes conselheiros com o passar do tempo, uma vez que os conselheiros que participam há mais tempo demonstraram ter mais cultura cívica e capital social. ${ }^{57}$

\section{Participação, deliberação e compartilhamento de valores}

Lembro que a participação em organizações associativas apresenta-se como prática de reivindicações e deliberações coletivas. Ao participarem destes espaços, visando a solucionar seus problemas, as pessoas se confrontam com diferentes concepções e opiniões acerca da coisa pública, e deliberam sobre aquilo que lhes é comum.

Isto pode ser observado pela multiplicidade de organizações das quais os conselheiros fazem parte, mesclando questões sindicais com as de saúde, estas com problemas de urbanização e organizações como partidos políticos.

As trajetórias e esforços dos conselheiros em relação à coisa pública, e seu alto grau de engajamento em ações coletivas, apontam na direção de uma questão: como se pode gerar e desenvolver laços mútuos e horizontais de reciprocidade, confiança e tolerância bem como se aguçar as percepções para o bem público e a disposição para a ação coletiva das pessoas?

Advoga-se a idéia de que, para que se desenvolva este ethos, não basta ir ao Estado com reivindicações pontuais, limitar-se ao voto sazonal para eleição das elites governantes, ou permanecer fazendo-se acordos auto-interessados e precisos. Faz-se necessário, antes, que se participe nas esferas de debates

\footnotetext{
${ }^{57}$ Cito dois exemplos que apareceram nesta pesquisa: o primeiro caso é o de um conselheiro que trabalha como voluntário na obra de ampliação de um posto de saúde - reforma a qual há muito eles reivindicavam no Conselho - a despeito de estar desempregado. O segundo caso, o de uma conselheira que ao ingressar no CGS de sua Subprefeitura, se solidarizou com o fato de as ambulâncias não chegarem no local onde moram devido à rua não ser asfaltada, e transformou seu carro "na ambulância da rua".
} 
públicos, o que contribuiria para a edificação e/ou fortalecimento de uma cultura política cívico-republicana.

Desta perspectiva, os espaços deliberativos assumem o significado estratégico de garantir a força integradora e a autonomia da prática de entendimento entre os cidadãos. Assim, o status de cidadão é definido pelo critério de liberdades positivas. Estas liberdades garantem a participação em uma prática comum, cujo exercício faz com que os cidadãos sejam "autores políticos responsáveis de uma comunidade de pessoas livres e iguais ... Esse poder [de autonomia da prática de entendimento] na realidade provém do poder comunicativamente gerado na prática da autodeterminação dos cidadãos e se legitima na medida em que protege essa prática por meio da institucionalização da liberdade pública" (Habermas, 1995, p. 41).

Assim, a sociedade civil é uma condição necessária para a democracia, uma vez que estimula a pluralidade de grupos de interesse que acabam sendo, posteriormente, representados na esfera política. Desta forma, ela se torna a base de uma fundação democrática sólida.

Remetendo-me novamente para os dados da pesquisa, vê-se que os conselheiros, de maneira geral, mostraram-se pessoas com alta pluralidade de participação civil: entidades beneficentes, associações recreativas, de auto-ajuda, de defesa dos consumidores, grupos de fé e política, sindicatos de trabalhadores, associações profissionais e partidos políticos, entre outras.

Esta diversidade de interação social faz da sociedade civil o lócus para o desenvolvimento de uma concepção de "comunidade política". O encontro destas diversas demandas em espaços como os Conselhos Gestores de Saúde pode promover um incremento comunitário e uma equivalência entre as instituições democráticas, além de poder facilitar a promoção uma identidade política compartilhada entre os sujeitos: uma concepção comum de cidadania. 
Isto pode ser exemplificado pelo padrão das respostas dadas pelos conselheiros a questões como o da doação de material público a um indivíduo privado ou o atendimento aos Sem Terra (discutidas no item $i$ do capítulo 03). Visivelmente os conselheiros demonstraram compartilhar uma noção pública e universalista do SUS ao terem defendido 0 atendimento integral aos Sem Terra, independentemente do que fosse ocorrer com o sistema de saúde da cidade (que não estava preparado para a elevação na quantidade de atendimentos). Também se observou este padrão com a declaração dos conselheiros de que sobras de material de obras públicas não deveriam ser dispensadas a particulares.

Pode-se, também, evidenciar esta criação e compartilhamento comunitário de uma noção de bem público com a estória do cidadão que foi enviado para tratamento em outra cidade, devido ao fato de sua cidade não possuir um hospital (item $i$ do capítulo 03 , tabelas 30 e 30.1 ). Os conselheiros afirmaram a necessidade de que a população da cidade sem hospital se unisse para reivindicar este equipamento. Isto demonstrou que a participação e a reivindicação se apresentaram construtos identitários comuns entre os membros dos Conselhos de Saúde, bem como o sistema público de saúde mostrou fazer parte de um ideário compartilhado de bem comum.

Este padrão de posicionamento foi edificado em um processo de deliberação comum entre os indivíduos, o qual permitiu que as pessoas construíssem uma identidade comunitária e uma noção de bem público.

Todavia, em situações de pluralismo cultural e social, por trás das metas politicamente relevantes, há interesses e orientações valorativas que podem ser consideradas individualmente. Estes interesses podem, contudo, ser evidenciados e negociados em uma deliberação pública devido às pretensões de validade inerentes ao processo comunicativo: a pretensão de verdade das afirmações feitas pelos participantes no processo comunicativo; à correção e à adequação das normas; e à veracidade (o que significa que os participantes do diálogo sejam sinceros na expressão dos seus sentimentos). 
"As negociações deste tipo pressupõem, certamente, a disponibilidade para a cooperação; a saber, a disposição de, respeitando as regras do jogo, chegar a resultados que possam ser aceitos por todas as partes, ainda que por razões distintas ... A despeito disso, a equidade dos compromissos é medida por condições e procedimentos que, por sua vez, necessitam de uma justificação racional (normativa) com respeito a se são justos ou não" (grifos do autor Habermas, 1995, p 44/45). Desta forma, a constituição de uma concepção de justiça pode se dar no e através do processo deliberativo.

Ao se trazer, novamente, os dados deste trabalho, especificamente o caso dos Sem Terra, vê-se que foi unânime entre os conselheiros a noção compartilhada do que seria justo em relação ao atendimento médico aos Sem Terra: o SUS é universal e gratuito (estas são as regras do jogo, e justificam-se pois todos necessitam de atendimento à saúde), logo os Sem Terra deveriam ter sido atendidos de qualquer maneira (ver item $i$ do capítulo 03 , tabelas 31 e 31.1).

O processo deliberativo do qual fizeram parte os conselheiros, além de ter gerado um ethos compartilhado de bem público e uma noção de justiça, demonstrou favorecer as pessoas que participaram de seus procedimentos no sentido de que estas desenvolveram cultura cívica, capital social, interesse pela política, confiança generalizada e aprimoraram seus valores democráticos.

Estes fatores se evidenciaram ao se olharem os grupos de conselheiros por tempo de participação: os grupos que disseram participar de processos deliberativos há mais tempo se mostraram mais confiantes no próximo, mais informados acerca da política, desenvolveram valores democráticos mais arraigados, e teceram redes mais amplas de capital social. 


\section{Comunidade e democracia}

Postas estas questões, defendo uma concepção cívico-republicana de bem público, a qual se fundamenta em um construto social edificado a partir da diversidade de interesses e pontos de vistas acerca dos assuntos da res publica.

Desta perspectiva, o principal valor da atividade política é a busca pelo bem comum, o qual só pode ser alcançado através da participação e deliberação ativas das pessoas nos assuntos da comunidade política.

Nestes processos, os cidadãos compartilham o compromisso de reconhecerem a legitimidade de suas diferenças e de associarem-se em função de decisões de ações comuns visando a objetivos públicos. Tal compromisso envolve a aceitação de princípios basais como a liberdade e a igualdade, e recoloca a noção de direitos de cidadania, não apenas calcada em nuances sócio-políticas, mas embasadas pela diversidade de identidades derivadas de relações culturais como raça, religião, sexo, etc.

Se a cidadania for entendida como uma identificação política com a res publica, criada através da participação e da deliberação, o indivíduo deixa de ser um recipiente passivo de direitos específicos e sob a proteção da lei.

Esta identidade política comum permitiria o engajamento de propostas diferentes, pois as pessoas estariam unidas por um arranjo de valores ético-políticos, com os quais se identificariam. Havendo tal identificação, os conflitos inerentes à esfera política seriam alocados em uma câmara de equivalências entre as diversas demandas (gays, mulheres, negros, etc.). Esta câmara não deveria estabelecer uma mera aliança entre os diversos interesses, mas ser o lócus no qual estas forças pudessem modificar mutuamente suas identidades.

Desta maneira, preservar-se-ia a disputa gerada pela pluralidade constante da esfera privada, que seria alocada em espaços de deliberações públicas, nos quais os atores envolvidos teriam a oportunidade de conhecer outras demandas e 
agirem em prol da geração de uma concepção do que seja o bem coletivo, bem como pela sua manutenção.

Neste sentido, nossos estudos apontaram para a possibilidade de desenvolvimento de uma consciência comunitária. Olhando os dados dos conselheiros que iniciaram sua participação no período anterior e/ou até 1980 e aqueles do período entre 1981 e 1992, vê-se que seu comportamento cívicorepublicano foi mais refinado do que os iniciaram suas atividades associativas recentemente (depois de 2001).

Apenas para se relembrar os dados discutidos no capítulo 04, os conselheiros dos períodos "anterior e/ou até 1980" e "entre 1981 e 1992" se mostraram pessoas com capital social bastante elevado, demonstraram deter alto índice de confiança generalizada e nas instituições policial e médica, evidenciaram ter mais apreço pelos valores democráticos e possuir percepções mais claras acerca das diretrizes normativas do SUS.

Desta forma, pode-se esperar que estes Conselhos Gestores de Saúde, e as tantas outras formas que assumem as esferas de deliberação públicas, venham a contribuir para um novo modelo de cidadania. Um modelo que não visaria apenas à promoção da igualdade, mas, também, à instituição de um cidadão questionador acerca da própria lógica da ação estatal, e que buscasse novas formas de participação e deliberação nas decisões e acerca delas.

Este novo status relacional não levaria apenas a uma reconfiguração das relações entre Estado e sociedade - pois as demandas desta nova sociedade não se dirigiriam apenas ao reconhecimento de determinada reivindicação por parte do Estado ou de outro grupo específico -, mas ao reconhecimento pelo conjunto da sociedade da legitimidade de uma situação particular.

Em uma democracia deliberativa, os atores sociais pertenceriam a uma comunidade política e se identificariam com os princípios éticos-políticos por terem feito parte do processo que estabeleceu o consenso expressado pela comunidade 
política. Estamos falando da conformação de cidadãos cívico-republicanos, que visariam a uma justiça igualitária na res publica, sem precisarem abrir mão de sua liberdade ou solapar a alheia.

Desta perspectiva, esta pesquisa apresentou evidências de que os processos de participação e deliberação públicas, se fomentados no tempo, podem ser o fundamento para a construção desta comunidade política. 


\section{BIBLIOGRAFIA}

ABERS, Rebecca. Inventando a Democracia: distribuição de recursos públicos através de participação popular em Porto Alegre, RS. 2001 in http://www.ongcidade.org/site/noticias/noticias completa. php?idNoticias=25.

ABRASCO (1993) Relatório final da oficina: incentivo à participação popular e controle social em saúde. (Série Saúde e movimento, n.1). Brasília: ABRASCO.

ABU-EL-HAJ, J. O Debate em Torno do Capital Social: Uma visão crítica in Bib, $\mathrm{n}^{\circ}$ 47, $1^{\circ}$ semestre, 1999.

ACHARYA, A. et all. Civil Society Representation in the Participatory Budget and Deliberative Councils of São Paulo. IDS Bulletin. Vol. 35, n 2. April 2004.

ALMOND G. e VERBA, S. The Civic Culture. Litlle Brown and Company. 1963.

ALONSO, A. e COSTA, V. The Dinamics of Public Hearings for Environmental Licensing: The case of São Paulo Ring Road. IDS Bulletin. Vol. 35, $n^{\circ} 2$. April 2004.

ARAUJO, C. Estado e Democracia. In de VITA, A. e BORON, A. (orgs.). Teoria e Filosofia Política. Edusp e CLACSO. 2004.

ARATO, A. e COHEN, J. redescobrindo a Sociedade Civil in AVRITZER, Leornardo (org). Sociedade Civil e Democratização. Del Rey editora. Belo Horizonte. 1994.

ASSOCIAÇÃO PALISTA DE SAÚDE PÚBLICA. Organizações Sociais: Público e Privado na Saúde. Gabinete do Vereador Adriano Diogo. São Paulo. Sem data.

AUGUSTO, Maria Helena Oliva. Política Social e Tecnologia em Saúde. Tese de Doutoramento - USP. São Paulo. 1986.

AUGUSTO, Maria Helena Oliva. Entre o Publico e o Privado. Tempo Social, vol. $10 \mathrm{n}^{\circ} 1$, fevereiro de 2000. São Paulo. 2000.

AVRITZER, L; Recamán, M.; Venturi, G. O Associativismo na cidade de São Paulo. in AVRITZER, L. (org). A Participação em São Paulo. Editora Unesp. 2004.

. Teoria Democrática e deliberação pública in Lua Nova, n 49, 2000.

BAQUERO, M. Democracia, Cultura e comportamento político: uma análise brasileira in PERISSINOTO, R. e FUKS, M. (orgs.) Democracia Teoria e Prática. Relumé Dumará. 2002. 
BARRY, Bryan. Sociologists, Economists and Democracy. University of Chicago Press. 1978.

BIGNOTTO, N. Origens do Republicanismo Moderno. UFMG. 2001

BIGNOTTO, N. O Republicanismo Hoje. UFMG. 2002.

BRESSER-PERREIRA, L. C. e GRAU, N. C. O Público Não-Estatal na Reforma do Estado. FGV e CLAD. 1999.

CARNEIRO, Carla Bronzo L. Conselhos: Uma reflexão sobre os condicionantes de sua atuação e os desafios de sua efetivação. Informativo CEPAM. Vol. 1; No. 3. Março. São Paulo: Fundação Prefeito Faria Lima. Pp: 62-70. 2002.

CARPINI, Michael X. DELLI; Cook, Fay Lomax y Jacobs, Lawrence R. (2003). "Talking Together: discursive capital and civil deliberation in America". Paper delivered to meeting of Midwest Political Science Association. Chicago.

CARVALHO, A.I. Conselhos de saúde no Brasil: participação cidadã e controle social. Rio de Janeiro: IBAM/ FASE. 1995.

CARVALHO, Maria do Carmo A. A. e Teixeira, Ana clauidia C.. Conselhos Gestores de Políticas Púbicas. Publicação Polis. 2000.

CARVALHO, Antonio Ivo de. Conselhos de Saúde, responsabilidade pública e cidadania: a reforma sanitária como reforma do Estado in FLEURY, Sonia (org.). Saúde e democracia: a luta do CEBES. Lemos editorial. 1997.

COELHO, Vera Schattan. "Brazil's Health Councils: The Challenge of Building Participatory Political Institutions". IDS Bulletin. Vol. 35. No.2. April, 2004. Brighton (UK). pp 33- 39. 2004.

COHEN, Jean. Trust, voluntary association ans workable democracy: the contemporary American discourse of civil society in WARREN, Mark E. (editor) Democracy and Trust. Cambridge University Press. 1999.

COHEN, Jean L. e ARATO, Andrew. Sociedad Civil y Teoría Política. Fondo de Cultura Económica. México. 2000.

COHN, A.; Elias, P. e Jacobi, P. Participação popular e gestão de serviços de saúde: Um olhar sobre a experiência do município de São Paulo, Revista Saúde em Debate, n. 38/ março. Brasil. 1993.

CONASENS. Relatório do XIV Congresso Nacional de Secretários Municipais de Saúde: Descentralização: Gestão Local Construindo Municípios Saudáveis. Athalaia. Goiânia. 1998. 
CONSELHO NACIONAL DE SAÚDE. Relatório Final da $11^{\text {a }}$ Conferência Nacional de Saúde: O Brasil falando como quer ser tratado. Série Histórica do CNS, nº 1. Brasília. 2000.

CONSELHO NACIONAL DE SAÚDE. Plenárias Nacionais de Conselhos de Saúde: Resgate Histórico do Controle Social no SUS in Série Histórica do Conselho Nacional de Saúde nº 3. Brasília. 2000.

CORNWALL, Andrea. New Democratic Spaces? The Politics and Dynamics of Institutionalised Participation, IDS Bulletin. Vol. 35. No.2. April, 2004. Brighton (UK). pp 1-10.

CÔRTES, S. M. V. Participação de usuários nos Conselhos municipais de saúde e de assstênica social de Porot Alegre. in PERISSINOTO, R. e FUKS, M. (orgs.) Democracia Teoria e Prática. Relumé Dumará. 2002.

DAGNINO, Evelina. Sociedade Civil, Espaços Públicos e a Construção Democrática no Brasil: Limites e Possibilidades in DAGNINO, Evelina (org). Sociedade Civil e Espaços Públicos no Brasil. Paz e Terra. 2000.

Democracia: Teoria e Prática: a participação da sociedade civil. in PERISSINOTO, R. e FUKS, M. (orgs.) Democracia Teoria e Prática. Relumé Dumará. 2002.

DAHL, R. Um prefácio a teoria democrática. Jorge Zahar. 1989. Paulo. 2005.

A Poliarquia: participação e oposição. Editora da Universidade de São

DOIMO, A. M. A Vez e a Voz do Popular - Movimentos sociais e participação política no Brasil pós-70. Rio de Janeiro: Relume-Dumará: ANPOCS, 1995.

e RODRIGUES, M. A. A formulação da nova política de saúde no Brasil em tempos de democratização: entre uma conduta estatista e uma concepção de atuação política in Política e Sociedade - Revista de Sociologia e Política, $n^{\circ}$ 03, outubro de 2003.

Pluralidade Religiosa à Brasileira, associtivismo e movimentos sociais em São Paulo in AVRITZER, L. (org.) A Participação em São Paulo. editora da UNESP. 2004.

ESCOREL, Sarah M. Reviravolta na saude: origem e articulacao do movimento sanitário. ? 1987.

FLEURY, S. A questão democrática na saúde in FLEURY, Sonia (org.). Saúde e democracia: a luta do CEBES. Lemos editorial. 1997. 
FISHKIN, James. The Voice of the People. Yale University Press. New Haven. 1995

FONT, Joan. Participación ciudadana y decisions públicas: conceptos, experiencias y metodologias. Mimeo. 2004.

FRIEDMANN, John. Empowerment - The Politics of Alternative Development. Blackwell Publishers. Massachusets. 1998.

FUNG, Archon. Receitas para esferas públicas: oito desenhos institucionais e suas conseqüências in COELHO, V. S. P. e NOBRE, M. (orgs) Participação e deliberação. Editora 34. 2004.

GAVENTA, John. Representation, Community Leadership and Participation: Citizen Involvement in Neighbourhood Renewal and Local Governance. Mimeo. 2004.

GOHN, Maria da Glória. 2003. O Papel dos Conselhos Gestores na Gestão Urbana in www.brasaus.org.

GONÇALVES, M.A.S. Teoria da ação comunicativa de Habermas: possibilidades de uma ação educativa de cunho interdisciplinar na escola in Educação Social, 1999, vol.20, n.66, p.125-140.

GOULART, Jefferson O. Poder Local e Novas Experiências Democráticas. Tese de doutoramento apresentada ao Departamento de Ciência Política da USP. 2002.

GOVERNO DO ESTADO DE SÃO PAULO. Oficina de Capacitação para Conselheiros de Saúde de Guarulhos. Secretaria de Estado da Saúde de SP. São Paulo. 2000.

GRÜNER, E. A Tragédia, ou o Fundamento Perdido do Político. In de VITA, A. e BORON, A. (orgs.). Teoria e Filosofia Política. Edusp e CLACSO. 2004.

HABERMAS, J. The theory of communicative action. Beacon Press, 1987.

HABERMAS, J. Três modelos normativos de democracia in Lua Nova, $\mathrm{n}^{\circ} 36$, 1995.

HE, Baogang. Civil Society and Democracy in WARREN, Mark E. (editor) Democracy and Trust. Cambridge University Press. 1999.

INSTITUTO POLIS/PUC-SP. Saúde:Conselho Municipal. Gráfica Peres. 2002.

LAVALLE, Adrián Gurza. Crítica ao Modelo da Nova Sociedade Civil in Lua Nova, $n^{\circ}$ 47. 1999. 
et all. Atores da sociedade civil e atores políticos: participação nas novas políticas democráticas em São Paulo in AVRITZER, L. (org). A Participação em São Paulo. Editora Unesp. 2004a.

et all. Lugares e atores da democracia: arranjos isntitucionais participativos e sociedade civil em São Paulo in COELHO, V. S. P. e NOBRE, M. (orgs) Participação e deliberação. Editora 34. 2004b.

LINHARES, Clarice Barretos. A Disseminação dos Orçamentos Participativos: Um breve panorama das experiências no Brasil de 1989 a 2004 in http://www.democraciaparticipativa.org, consultada em 23/01/2006, ás 12:02hs.

LOCKE, R. M. Building Trust. Artigo apresentado no "Annual Meetings of the American Political Science Association”. San Francisco. 2001.

MCPHERSON, C.B. The Life and Times of Liberal Democracy. Oxford University Press. 1977.

MARSHALL, T.H. Cidadania, classe social e status. Zahar. 1967.

MICHELS, R. Partidos Políticos. Senzala. 1987.

MINISTÉRIO DA SAÚDE. A Prática do Controle Social in Série Histórica do CNS, nº1. Ministério da Saúde. Brasília. 2000

MINISTÉRIO DA SAÚDE. O Sistema Público de Saúde Brasileiro. Ministério da Saúde. Brasília. 2002.

MINISTÉRIO DA SAÚDE. O Sistema de Saúde Brasileiro in Experiências Inovadoras. Agosto, n¹. Ministério da Saúde. Brasília. 2002.

MINISTÉRIO DA SAÚDE. O Conselho de Saúde: Manual $\mathrm{n}^{\circ} 1$. Instituto Sallus. Brasília. 2000.

MOTTA, Carlos Renato. As novas formas de participação social nas políticas públicas. Revista on line de economia da UFRJ in www.furj.br. 2005.

MOISÉS, José Álvaro. Os brasileiros e a democracia. Editora Ática. 1995.

A desconfiança dos cidadãos de instituições democráticas.

Texto não publicado apresentado para discussão do grupo de pesquisa coordenado pelo Prof. Dr. José Álvaro Moisés. 2005.

MOUFFE, Chantal. Democratic Citizenship and the Political Community in MOUFFE, Chantal (editor). Dimensions of Radical Democracy. Verso Press. 1992. 
NEWTON, K. e NORRIS, P. Confidence in Public Institutions: faith, culture or performance? In PHARR, S. J. e PUTNAM, R. D. Princeton University Press. 2000.

NOBRE, M. Participação e deliberação na teoria democrática: uma introdução in COELHO, V. S. P. e NOBRE, M. (orgs) Participação e deliberação. Editora 34. 2004.

NORRIS, Pippa. The Grouwth of Critical Citizens? in NORRIS, Pippa (editor). Critical Citizens. Oxford University Press. 1999.

OFFE, Claus. How can we trust our fellow citizens? in WARREN, M. (editor) Democracy and Trust. Cambridge University Press. 2001.

ORTEGA, Francisco. Para uma política da amizade: Arendt, Derrida, Foucault. Relume Dumará. 2000.

OSTROM, E. e AHN, T.K. A social science perspective on social capital: social capital and collective action. Artigo apresentado na "European Research Conference on 'Social Capital: Interdisciplinary Perspectives', Exeter, United Kingdom, September 15-20, 2001.

PATEMAN, Carole. The civic culture: a philosophic critique. The civic culture revisited. Boston: Litle, Brown and Company, 1989. . Participação e teoria democrática. Paz e Terra. 1992.

PEDROSO, Marcel de Moraes. Desenvolvimento humano no município de São Paulo. Dissertação de Mestrado apresentada para o Departamento de Economia Política da PUC/SP. 2003.

PETTIT, P. Republicanism. Oxford University Press. 1997.

PUTNAM, Robert. The Prosperous Community: social capital and public life. The American Prospect 13. 1993.

Simon \& Schuster. 1999. . Bowling Alone: the collapse and revival of American community. Editora da FGV. 2001. Comunidade e Democracia: a experiência da Itália Moderna.

RIBEIRO, R. J. A república. Publifolha. 2001.

A democracia. Publifolha. 2002. 
RODGRIGUES NETO, Eleutério. A via do parlamento in FLEURY, Sonia (org.). Saúde e democracia: a luta do CEBES. Lemos editorial. 1997.

ROJAS, Cristina. Forging Civic Culture in Bogotá City. Artigo apresentado no workshop 'Citizen Participation in the Context of Fiscal Decentralization: Best Practices in Municipal Administration in Latin America and Asia, Tokyo and Kobe'. Asian Development Bank. 2002.

SADER, Eder. Quando Novos Personagens Entram em Cena. Paz e Terra. Rio de Janeiro. 1988.

SADDI, Fabiana da Cunha. Estado, Sociedade e descentralização da política pública de saúde no México (1982-2000) e no Brasil (1985-1998): construindo um novo domínio público em contexto de dupla transição política. Tese de Doutorado apresentada ao Departamento de Sociologia da USP. 2004.

SCHATTAN, Vera et all. IDS Bulletin. Making Rights Real. Vol. 33, n² 2. April 2002.

et all. Brazil's Health Councils: The Chalenge of Builfing Participatory Political Institutions. IDS Bulletin. Vol. 35, n² 2. April 2004.

e VERÍSSIMO, José. Considerações sobre o processo de escolha dos representantes da sociedade civil nos Conselhos de Saúde em São Paulo in AVRITZER, L. (org). A Participação em São Paulo. Editora Unesp. 2004

SCHIMITTER, Philippe C. Participation in Governance Arrangements. European University Institute. Mimeo. 2001.

SCHUMPETER, J. Capitalismo, socialismo e democracia. Editora Fundo de Cultura. 1961.

SECRETARIA DE SAÚDE DO RIO GRANDE DO SUL. SUS é Legal: Legislação Federal e Estadual. Conselho Estadual de Saúde da Secretaria da Saúde do RS. 2000.

SEYD, Patrick e WHITELEY, Paul. Is Britain still a civic culture? Artigo apresentado para o encontro anual do grupo de British Politics da American Political Science Association. Setembro de 2002.

SHEPSLE , Kenneth A. e BONCHEK, Mark S. Analyzing politics: rationality, behavior, and institutions. W.W. Norton. 1997.

SPOSATI, A. e Lobo, E. Controle social e políticas públicas. In: Cadernos de Saúde Pública, Vol.4, No.8. Brasil. 1992.

TARROW, Sidney. Making Social Science Work Across Space and Time: a critical reflection on Robert Putnam's Making Democracy Work in The American Political Science Review, vol. 90, nº2, (389-397), June, 1996. 
TEIXEIRA, Elenaldo Celso. Sociedade Civil e Participação Cidadã no Poder Local. Editora UFBA. 2000.

VIANA, Ana L. Desenho, modo de operação e representação dos interesses do sistema municipal de saúde e os conselhos de saúde in Revista Ciência e Saúde Coletiva. Vol. III, No.1. Brasil. 1998.

TENDLER, J. \& FRIEDHEIN, S. Trust in a Rent-Seeking world: health and government transformed in northeast Brazil. World Development, vol. 22, nº 12.

VIEIRA, Liszt. Cidadania e sociedade civil no espaço público democrático. Revista on line da PUC - Rio, em 03/01/2005 in www.pucrio.br/sobrepuc/depto/direito/revista/online/rev11_liszt.html.

VITALE, D. Democracia direta e poder local: a experiência brasileira do Orçamento Participativo in COELHO, V. S. P. e NOBRE, M. (orgs) Participação e deliberação. Editora 34. 2004.

WAMPLER, B e AVRITZER, L. Públicos Participativos: sociedade civil e novas instituições no Brasil democrático in COELHO, V. S. P. e NOBRE, M. (orgs) Participação e deliberação. Editora 34. 2004.

WAMPLER, B. Instituições, Associações e interesses no orçamento participativo de São Paulo in AVRITZER, L. A participação em São Paulo, Editora da UNESP. 2004.

WARREN, Mark E. Introduction in WARREN, Mark E. (editor) Democracy and Trust. Cambridge University Press. 2001.

WEBER, M. Conceitos Básicos de Sociologia. Editora Moraes. 1987. 


\section{a) DESCRIÇÃO DA METODOLOGIA PARA ESCOLHA DOS CONSELHOS E CONSELHEIROS ESTUDADOS}

Como se colocou nos capítulos três e quatro utilizou-se diversos indicadores para a construção do Índice de Institucionalidade que serviu à seleção dos Conselhos que estudados neste trabalho.

Selecionaram-se três categorias de informações com base no banco de dados fruto da pesquisa Construindo Conselhos que Façam a Diferença, desenvolvida no CEBRAP: i) Indicadores de Organização (IOrg), ii) Índicadores de Empenho do Gestor (IEG) e o iii) Indicadores de Publicização dos Conselhos (IP). Já para a quarta categoria de indicadores, Índicores de Taxa de Ocupação (ITO), utilizaramse dados dos próprios Conselhos Gestores.

Os Índice de Desenvolvimento Humano - Municipal (IDH-M), é oriundos de estudos secundários (Pedroso, 2003 e PMSP).

Neste apêndice apresenta-se a descrição da metodologia empregada para se construir estes índices.

\section{A escolha dos Conselhos estudados}

Os dados dos indicadores de organização, de empenho do gestor e de publicização, como se disse, foram retirados das respostas às questões do questionário aplicado aos 31 Conselhos Gestores de Saúde de São Paulo. ${ }^{58}$ Para cada questão foi atribuído um valor máximo, de acordo com a resposta dada. Estes valores foram somados, depois padronizados por uma fórmula aritmética

\footnotetext{
${ }^{58}$ Estudo feito no CEBRAP, 2004. Detalhes desta pesquisa foram apresentados no capítulo 03.
} 
simples que ordenou seus resultados, de forma que sua variação final se apresentou entre os valores 0,00 a $1,00 .{ }^{59}$

As questões que se utilizaram para cada categoria, e seus respectivos valores máximos, foram as seguintes:

I. Indicadores de Organização: existência de Regimento Interno publicado em Diário Oficial (1); existência de documentação relativa ao processo eleitoral (1); homologação e divulgação, também em Diário Oficial, da composição do Conselho (1); existência de coordenador fixo para as reuniões do pleno do Conselho (1); existência de banco de dados nos quais constem informações sobre os movimentos sociais presentes na região (1); existência e quantidade de comissões elaboradas pelo Conselho (14); se ha acordo para duração das reuniões (1); se este tempo é seguido (1); se a presença dos conselheiros é registrada em ata própria para este fim (1); se a pauta da última reunião foi composta pelos três segmentos envolvidos nos Conselhos (usuários, governo e servidores sa saúde) (3); se as pessoas que presidem as reuniões tiveram treinamento para desempenhar esta atividade (1); quais e quantas as atividades desenvolvidas pelo Conselho (11); se o Conselho possui Secretaria Geral (1); quantos funcionários tem a Secretaria Geral (tantos pontos quantos funcionários existirem); se os Conselhos Gestores das Subprefeituras têm informações arquivadas em bancos de dados acerca dos Conselhos Gestores das Unidades de Saúde de sua região (1); e, finalmente, se as Unidades de Saúde da Subprefeitura encaminham dados sobre seu funcionamento para os Conselhos Gestores (1).

A tabela abaixo demonstra o Índice Organizacional para as 31 Subprefeituras, e seus dados foram sinalizados de forma que os valores em verde encontram-se acima do valor da mediana $(0,54)$; já os valores em vermelho indicam os Conselhos que estão posicionados abaixo desta linha. A própria mediana está

\footnotetext{
${ }^{59}$ A fórmula é a seguinte: (valor observado - menor valor do conjunto) / (Maior valor do conjunto menor valor do conjunto), ou (VO-Mvc) / (Mvc-mvc).
} 
assinalada em azul. A coluna "total" indica a soma dos valores das variáveis utilizadas para a construção do índice.

TABELA 01 - APRESENTAÇÃO DO ÍNDICE ORGANIZACIONAL PARA AS 31 SUBPREFEITURAS DE SÃO PAULO, 2005.

\begin{tabular}{|l|c|c|}
\hline \multicolumn{3}{|c|}{ INDICE ORGANIZACIONAL } \\
\hline \multicolumn{1}{|c|}{ Subprefeitura } & Total & IOrg \\
\hline Aricanduva & 27 & 0,89 \\
\hline Butantã & 20 & 0,64 \\
\hline Campo Limpo & 17 & 0,54 \\
\hline Casa Verde & 18 & 0,57 \\
\hline Cidade Ademar & 28 & 0,93 \\
\hline Cidade Tiradentes & 19 & 0,61 \\
\hline Ermelino & 15 & 0,46 \\
\hline Freguesia do O & 17 & 0,54 \\
\hline Guaianazes & 15 & 0,46 \\
\hline Ipiranga & 2 & 0,00 \\
\hline Itaim Paulista & 11 & 0,32 \\
\hline Itaquera & 9 & 0,25 \\
\hline Jabaquara & 16 & 0,50 \\
\hline Jd Ângela & 5 & 0,11 \\
\hline Lapa & 24 & 0,79 \\
\hline Mooca & 17 & 0,54 \\
\hline Parelheiros & 26 & 0,86 \\
\hline Penha & 20 & 0,64 \\
\hline Perus & 20 & 0,64 \\
\hline Pinheiros & 18 & 0,57 \\
\hline Pirituba & 20 & 0,64 \\
\hline Santana & 30 & 1,00 \\
\hline Santo Amaro & 16 & 0,50 \\
\hline São Mateus & 13 & 0,39 \\
\hline São Miguel & 17 & 0,54 \\
\hline Sé & 16 & 0,50 \\
\hline Socorro & 15 & 0,46 \\
\hline Tremembé & 20 & 0,64 \\
\hline VI Maria & 22 & 0,71 \\
\hline VI Mariana & 30 & 1,00 \\
\hline VI Prudente/Sapopemba & 12 & 0,36 \\
\hline FONTE:Banco cas & \\
\hline
\end{tabular}

FONTE: Banco de dados CEBRAP/IDS. 2004

II. Indicadores de Empenho do Gestor: se o Conselho tem verba própria para sua atuação (1); se o Conselho mantém relações com o Secretário de Saúde (1) e com o Subprefeito (1); se o Subprefeito encaminha material acerca da 
Subprefeitura para o Conselho (1); se o Coordenador de Saúde da Subprefeitura vai às reuniões do Conselho (1); que tipos de dados a Coordenadoria de Saúde disponibiliza ao Conselho (4); como se dá a disponibilização destes dados (4); se o Coordenador de Saúde recebe o Conselho em seu gabinete (1); com que freqüência o Coordenador recebe o Conselho em seu gabinete (2); se há algum tipo de dificuldade para o Conselho obter dados da Coordenadoria de Saúde (2); se os Vereadores encaminham seus projetos da área da saúde para os Conselhos (1); se o Conselho já recorreu à Comissão de Saúde da Câmara dos Vereadores (1).

A tabela abaixo demonstra os valores obtidos para o índice. As cores, seguindo o padrão do índice anterior indicam, em vermelho os valores abaixo da mediana, esta em azul $(0,69)$, e os valores em cor verde indicam que os valores estão acima deste patamar. 


\section{TABELA 02 - APRESENTAÇÃO DO ÍNDICE DE EMPENHO DO GESTOR PARA AS 31 SUBPREFEITURAS DE SÃO PAULO, 2005.}

\begin{tabular}{|l|c|c|}
\hline \multicolumn{3}{|c|}{ INDICE DE EMPENHO DO GESTOR } \\
\hline \multicolumn{1}{|c|}{ Conselho } & Total & IEG \\
\hline Aricanduva & 18 & 1,00 \\
\hline Butantã & 12 & 0,63 \\
\hline Campo Limpo & 13 & 0,69 \\
\hline Casa Verde & 11 & 0,56 \\
\hline Cidade Ademar & 11 & 0,56 \\
\hline Cidade Tiradentes & 11 & 0,56 \\
\hline Ermelino & 16 & 0,88 \\
\hline Freguesia do O & 10 & 0,50 \\
\hline Guaianazes & 16 & 0,88 \\
\hline Ipiranga & 2 & 0,00 \\
\hline Itaim Paulista & 9 & 0,44 \\
\hline Itaquera & 5 & 0,19 \\
\hline Jabaquara & 14 & 0,75 \\
\hline Jd Ângela & 3 & 0,06 \\
\hline Lapa & 12 & 0,63 \\
\hline Mooca & 14 & 0,75 \\
\hline Parelheiros & 15 & 0,81 \\
\hline Penha & 12 & 0,63 \\
\hline Perus & 14 & 0,75 \\
\hline Pinheiros & 13 & 0,69 \\
\hline Pirituba & 13 & 0,69 \\
\hline Santana & 17 & 0,94 \\
\hline Santo Amaro & 12 & 0,63 \\
\hline São Mateus & 13 & 0,69 \\
\hline São Miguel & 13 & 0,69 \\
\hline Sé & 13 & 0,69 \\
\hline Socorro & 14 & 0,75 \\
\hline Tremembé & 12 & 0,63 \\
\hline VI Maria & 14 & 0,75 \\
\hline VI Mariana & 7 & 0,31 \\
\hline VI Prudente/Sapopemba & 13 & 0,69 \\
\hline FONTE: Banco de dados CEBRAP/IDS. & 2004 & \\
\hline
\end{tabular}

III. Indicadores de Publicização: qual foi o método escolhido para convidar as associações que fizeram parte da primeira eleição do pleno (3); quais os métodos de divulgação das eleições do Conselho (10); se a pauta das reuniões é disponibilizada para o público (1); quais os meios de divulgação desta pauta (tantos pontos quanto meios de divulgação); maneiras de divulgação das deliberações do pleno (13); quantos movimentos sociais estão presentes no 
Conselho (tantos pontos quantos movimentos existirem); se o Conselho convida associações ligadas à saúde para suas reuniões (1); a quais instâncias do governo e da sociedade civil o Conselho já recorreu para exercer suas atividades (10); se o Conselho já organizou encontro com munícipes em geral (1); se organizou a Conferência Distrital de Saúde (1); quais os métodos que utilizou para divulgar estas atividades (18); qual era o intuito do evento organizado (7).

Este índice, seguindo-se a convenção de cores adotada, apresentou-se desta forma: 
TABELA 03 - APRESENTAÇÃO DO ÍNDICE DE PUBLICIDADE PARA AS 31 SUBPREFEITURAS DE SÃO PAULO, 2005.

\begin{tabular}{|l|c|c|}
\hline \multicolumn{3}{|c|}{ INDICE PUBLICIZAÇÃO } \\
\hline \multicolumn{1}{|c|}{ Subprefeitura } & Total & IP \\
\hline Aricanduva & 18 & 0,50 \\
\hline Butantã & 20 & 0,57 \\
\hline Campo Limpo & 13 & 0,32 \\
\hline Casa Verde & 14 & 0,36 \\
\hline Cidade Ademar & 31 & 0,96 \\
\hline Cidade Tiradentes & 16 & 0,43 \\
\hline Ermelino & 16 & 0,43 \\
\hline Freguesia do O & 25 & 0,75 \\
\hline Guaianazes & 16 & 0,43 \\
\hline Ipiranga & 4 & 0,00 \\
\hline Itaim Paulista & 28 & 0,86 \\
\hline Itaquera & 18 & 0,50 \\
\hline Jabaquara & 22 & 0,64 \\
\hline Jd Ângela & 10 & 0,21 \\
\hline Lapa & 17 & 0,46 \\
\hline Mooca & 11 & 0,25 \\
\hline Parelheiros & 20 & 0,57 \\
\hline Penha & 18 & 0,50 \\
\hline Perus & 18 & 0,50 \\
\hline Pinheiros & 29 & 0,89 \\
\hline Pirituba & 23 & 0,68 \\
\hline Santana & 25 & 0,75 \\
\hline Santo Amaro & 15 & 0,39 \\
\hline São Mateus & 14 & 0,36 \\
\hline São Miguel & 31 & 0,96 \\
\hline Sé & 26 & 0,79 \\
\hline Socorro & 27 & 0,82 \\
\hline Tremembé & 19 & 0,54 \\
\hline VI Maria & 23 & 0,68 \\
\hline VI Mariana & 32 & 1,00 \\
\hline VI Prudente/Sapopemba & 9 & 0,18 \\
\hline FONTE:Banco dedados CEBRAPIDS & 204 \\
\hline
\end{tabular}

FONTE: Banco de dados CEBRAP/IDS. 2004

IV. Indicador de Taxa de Ocupação: $O$ dado que se utilizou para o Indicador da Taxa de Ocupação foi o número de cadeiras ocupadas nos Conselhos pelos conselheiros usuários do SUS. Como se sabe, os Conselhos são compostos por usuários do SUS (50\% das cadeiras), governo $(12,5 \%)$, trabalhadores da saúde (25\%) e prestadores de serviços (12,5\%). 
Optou-se por elaborar o ITO apenas com a amostra dos Conselheiros usuários, pois o foco de análise o qual se propôs esta pesquisa foi o padrão cívico deste segmento de Conselheiros. Isto também se justifica uma vez que os Conselheiros dos outros segmentos têm relações orgânicas com os Conselhos, seja por vínculos com o projeto político como os representantes do governo, pela manutenção da profissão que desempenham como é o caso dos trabalhadores, ou por visarem à nutrição de relações comerciais com o governo, como os prestadores de serviços.

Desta forma, visando-se a tentar minimizar vícios corporativistas e/ou de clientela política ou comercial, detivemos nossas atenções nos usuários do Sistema Único de Saúde.

Feitas estas considerações, demonstra-se como o índice foi composto: das 24 cadeiras destinadas aos Conselheiros usuários (12 titulares e 12 suplentes), somaram-se as ocupadas, e apôs-se a mesma fórmula aritmética aplicada aos demais índices, a qual (VO-mVC) / (MVC-mVC). Desta forma, o maior valor do conjunto representa a totalidade possível de ocupação das cadeiras destinadas aos usuários do SUS: 24 assentos. Os dados finais apresentaram-se da seguinte forma: 
TABELA 04 - APRESENTAÇÃO DO ÍNDICE TAXA DE OCUPAÇÃO PARA AS 31 SUBPREFEITURAS DE SÃO PAULO, 2005.

\begin{tabular}{|l|c|c|c|}
\hline \multicolumn{4}{|c|}{ INDICE DE TAXA DE OCUPAÇÃO } \\
\hline \multicolumn{1}{|c|}{ Subprefeitura } & \% (N=24) & N & ITO \\
\hline Aricanduva & $91,67 \%$ & 22 & 0,85 \\
\hline Butantã & $66,67 \%$ & 16 & 0,38 \\
\hline Campo Limpo & $100,00 \%$ & 24 & 1,00 \\
\hline Casa Verde & $100,00 \%$ & 24 & 1,00 \\
\hline Cidade Ademar & sem dados & 0 & 0 \\
\hline Cidade Tiradentes & $100,00 \%$ & 24 & 1,00 \\
\hline Ermelino & sem dados & 0 & 0 \\
\hline Freguesia & sem dados & 0 & 0 \\
\hline Guaianazes & $62,50 \%$ & 15 & 0,31 \\
\hline Ipiranga & $83,33 \%$ & 20 & 0,69 \\
\hline Itaim Paulista & sem dados & 0 & 0 \\
\hline Itaquera & $100,00 \%$ & 24 & 1,00 \\
\hline Jabaquara & $66,67 \%$ & 16 & 0,38 \\
\hline Jd Ângela & sem dados & 0 & 0 \\
\hline Lapa & $100,00 \%$ & 24 & 1,00 \\
\hline Mooca & sem dados & 0 & 0 \\
\hline Parelheiros & $100,00 \%$ & 24 & 1,00 \\
\hline Penha & $83,33 \%$ & 20 & 0,69 \\
\hline Perus & $100,00 \%$ & 24 & 1,00 \\
\hline Pinheiros & $79,17 \%$ & 19 & 0,62 \\
\hline Pirituba & $100,00 \%$ & 24 & 1,00 \\
\hline Santana & sem dados & 0 & 0 \\
\hline Santo Amaro & $62,50 \%$ & 15 & 0,31 \\
\hline Sao Mateus & $91,67 \%$ & 22 & 0,85 \\
\hline São Miguel & sem dados & 0 & 0 \\
\hline Se & $100,00 \%$ & 24 & 1,00 \\
\hline Socorro & $100,00 \%$ & 24 & 1,00 \\
\hline Tremembe & sem dados & 0 & 0 \\
\hline VI Maria & $45,83 \%$ & 11 & 0,00 \\
\hline VI Mariana & $87,50 \%$ & 21 & 0,77 \\
\hline VI Prudente/Sapopemba & $100,00 \%$ & 24 & 1,00 \\
\hline FONTE: listas de presença dos Conselhos Gestores, $2004-05$ & - Subprefeituras \\
& & & \\
\hline
\end{tabular}

V. O IDH-M que se utilizou foi confeccionado levando em consideração as seguintes variáveis: i) longevidade: medida pela esperança de vida ao nascer, mantendo-se inalterados os padrões de mortalidade prevalecentes na época do nascimento. Este indicador reflete as condições de saúde, mortalidade infantil, nutrição, higiene, acesso a serviços públicos básicos, e mortalidade decorrente da violência; ii) renda: medida pelo poder de compra da população, baseado no PIB 
per capita e ajustado ao custo de vida local; e iii) educação: medida por uma combinação da taxa de alfabetização de adultos e a taxa combinada de matrícula nos níveis de ensino fundamental, médio e superior. ${ }^{60}$

A idéia de se apresentar o IDH-M é a de manter-se ceteris paribus possíveis variações nos resultados da pesquisa, as quais possam ser promovidas por uma sensível alteração socioeconômica das áreas selecionadas. Os valores totais foram os seguintes:

${ }^{60}$ Para maiores informações acerca do IDH-M selecionado, ver: PEDROSO, Marcel de Moraes. Desenvolvimento humano no município de São Paulo. Dissertação de Mestrado apresentada ao Departamento de Economia Política da Pontifícia Universidade Católica de São Paulo. 2003. 


\section{TABELA 06 - APRESENTAÇÃO DO ÍNDICE DE DESENVOLVIMENTO HUMANO PARA AS 31 SUBPREFEITURAS DE SÃO PAULO, 2003.}

\begin{tabular}{|l|c|}
\hline \multicolumn{2}{|c|}{ IDH-M } \\
\hline \multicolumn{1}{|c|}{ SUBPREFEITURA } & IDH-M \\
\hline Aricanduva & 0,763 \\
\hline Butantã & 0,790 \\
\hline Campo Limpo & 0,740 \\
\hline Casa Verde & 0,730 \\
\hline Cidade Ademar & 0,695 \\
\hline Cidade Tiradentes & 0,672 \\
\hline Ermelino Matarazzo & 0,732 \\
\hline Freguesia do Ó & 0,700 \\
\hline Guaianases & 0,674 \\
\hline Ipiranga & 0,767 \\
\hline Itaim Paulista & 0,671 \\
\hline Itaquera & 0,710 \\
\hline Jabaquara & 0,733 \\
\hline Jardim Ângela & 0,644 \\
\hline Lapa & 0,853 \\
\hline Mooca & 0,800 \\
\hline Parelheiros & 0,650 \\
\hline Penha & 0,735 \\
\hline Perus & 0,698 \\
\hline Pinheiros & 0,910 \\
\hline Pirituba & 0,711 \\
\hline Santana & 0,810 \\
\hline Santo Amaro & 0,856 \\
\hline São Mateus & 0,676 \\
\hline São Miguel & 0,677 \\
\hline Sé & 0,842 \\
\hline Socorro & 0,671 \\
\hline Tremembé & 0,680 \\
\hline Vila Maria & 0,735 \\
\hline Vila Mariana & 0,880 \\
\hline Vl Prudente/Sapopemba & 0,699 \\
\hline FONTE: PEDROSO, M. 2001 \\
\hline
\end{tabular}




\section{A escolha dos conselheiros estudados}

Para a seleção dos conselheiros estudados, considerou-se a efetividade de sua participação, medida pelo número de associações de cunho participativo das quais eles fizeram (ou fazem) parte.

Dividiram-se os tipos de participação em duas categorias de engajamento pregresso entre os conselheiros: "antes de 1980 até 1992" e "a partir de 2001". 61 Estes grupos apresentaram características de participação distintas entre si. Para se ver detalhes das características destes grupos remeter-se ao capítulo três deste trabalho.

Os dados das tabelas abaixo foram padronizados em um indicador sintético chamado de Índice de Efetividade de Participação, para variarem de zero $(0,00)$ a um $(1,00)$. Para as entrevistas, selecionaram-se 02 Conselheiros presentes nos dois primeiros quartis, e dois que estivessem nos dois últimos, em cada CGS.

No Conselho de Parelheiros os conselheiros selecionados para a entrevista foram: P5, P8, P9 e P12.

\footnotetext{
${ }^{61} \mathrm{Na}$ análise dos dados estes grupos foram divididos em três para evitar-se vieses nos resultados, uma vez que se fossem agregados em apenas dois grupos, um deles ficaria com 11 casos e o outro com 05. Agregados em três categorias, obteve-se três grupos homogêneos: "até 1980" com 05 casos, "entre 1981 e 1992" com 06 casos" e "a partir de 2001" com 05.
} 
TABELA 07 - SELEÇÃO DOS CONSELHEIROS DE PARELHEIROS, 2005.

\begin{tabular}{|c|c|c|c|c|c|}
\hline \multicolumn{6}{|c|}{ Parelheiros } \\
\hline \multirow[b]{2}{*}{ Conselheiro } & \multicolumn{3}{|c|}{ período de participação } & \multirow[b]{2}{*}{ total } & \multirow[b]{2}{*}{ IP } \\
\hline & $\begin{array}{c}\text { período } \\
\text { anterior e/ou } \\
\text { até } 1980\end{array}$ & $\begin{array}{c}\text { entre } \\
1981 \text { até } \\
1992\end{array}$ & $\begin{array}{c}\text { a partir } \\
\text { de } \\
2001\end{array}$ & & \\
\hline \multicolumn{6}{|l|}{ P1 } \\
\hline $\mathrm{P} 2$ & & 1 & 1 & 2 & 0,00 \\
\hline P3 & \multicolumn{5}{|c|}{ sem dados } \\
\hline P4 & & 2 & 2 & 4 & 0,67 \\
\hline P5 & 0 & 1 & 1 & 2 & 0,00 \\
\hline P6 & & 1 & 4 & 5 & 1,00 \\
\hline $\mathrm{P} 7$ & & 2 & 2 & 4 & 0,67 \\
\hline P8 & 1 & 0 & 1 & 2 & 0,00 \\
\hline P9 & 0 & 0 & 5 & 5 & 1,00 \\
\hline P10 & & 0 & 4 & 4 & 0,67 \\
\hline P11 & \multicolumn{5}{|c|}{ sem dados } \\
\hline $\mathrm{P} 12$ & 0 & 4 & 1 & 5 & 1,00 \\
\hline
\end{tabular}

FONTE: VERISSIMO, 2005.

Os conselheiros de Vila Prudente demonstraram ter participado mais até 1992, do que a partir de 2001. Para a pesquisa selecionaram-se os conselheiros VP01, VP03, VP09 e VP 12. 
TABELA 09 - SELEÇÃO DOS CONSELHEIROS DE VILA PRUDENTE, 2005.

\begin{tabular}{|c|c|c|c|c|c|}
\hline \multicolumn{6}{|c|}{ Vila Prudente } \\
\hline \multirow[b]{2}{*}{ Conselheiro } & \multicolumn{3}{|c|}{ período de participação } & \multirow[b]{2}{*}{ total } & \multirow[b]{2}{*}{ IP } \\
\hline & $\begin{array}{c}\text { período } \\
\text { anterior e/ou } \\
\text { até } 1980\end{array}$ & $\begin{array}{c}\text { entre } \\
1981 \text { até } \\
1992\end{array}$ & $\begin{array}{l}\text { a partir } \\
\text { de } 2001\end{array}$ & & \\
\hline VP1 & 2 & 2 & 3 & 7 & 0,86 \\
\hline VP2 & \multicolumn{5}{|c|}{ sem dados } \\
\hline VP3 & 0 & 0 & 1 & 1 & 0,00 \\
\hline VP4 & \multicolumn{5}{|c|}{ sem dados } \\
\hline VP5 & \multicolumn{5}{|c|}{ sem dados } \\
\hline VP6 & & 4 & 0 & 4 & 0,43 \\
\hline VP7 & & 5 & 0 & 5 & 0,57 \\
\hline VP8 & & 5 & 3 & 8 & 1,00 \\
\hline VP9 & 0 & 0 & 1 & 1 & 0,00 \\
\hline VP10 & \multicolumn{5}{|c|}{ sem dados } \\
\hline VP11 & \multicolumn{5}{|c|}{ sem dados } \\
\hline VP12 & 0 & 1 & 4 & 5 & 0,57 \\
\hline
\end{tabular}

FONTE: VERISSIMO, 2005.

Para os conselheiros de Cidade Tiradentes demonstraram ser pessoas que participavam em mais de duas associações até 1992, e a partir de 2001 engajaram-se, em sua maioria, em duas ou mais instituições. Para as entrevistas deste Conselho selecionaram-se os conselheiros СT01, СT07, СТ 08 e СT09. 
TABELA 10 - SELEÇÃO DOS CONSELHEIROS DE CIDADE TIRADENTES, 2005.

\begin{tabular}{|c|c|c|c|c|c|}
\hline \multicolumn{6}{|c|}{ Cidade Tiradentes } \\
\hline \multirow[b]{2}{*}{ Conselheiro } & \multicolumn{3}{|c|}{ período de participação } & \multirow[b]{2}{*}{ total } & \multirow[b]{2}{*}{ IEP } \\
\hline & $\begin{array}{c}\text { período } \\
\text { anterior } \\
\text { elou até } \\
1980\end{array}$ & $\begin{array}{c}\text { entre } \\
1981 \\
\text { até } \\
1992\end{array}$ & $\begin{array}{l}\text { a partir } \\
\text { de } 2001\end{array}$ & & \\
\hline CT1 & 0 & 0 & 2 & 2 & 0,00 \\
\hline CT2 & \multicolumn{5}{|c|}{ sem dados } \\
\hline СТ3 & \multicolumn{5}{|c|}{ sem dados } \\
\hline CT4 & \multicolumn{5}{|c|}{ sem dados } \\
\hline CT5 & \multicolumn{5}{|c|}{ sem dados } \\
\hline СT6 & & 0 & 2 & 2 & 0,00 \\
\hline СT7 & 0 & 1 & 1 & 2 & 0,00 \\
\hline СТ8 & 2 & 1 & 4 & 7 & 0,63 \\
\hline CT9 & 0 & 5 & 5 & 10 & 1,00 \\
\hline CT10 & 0 & 4 & 2 & 6 & 0,50 \\
\hline CT11 & 0 & 3 & 2 & 5 & 0,38 \\
\hline CT12 & 0 & 2 & 1 & 3 & 0,13 \\
\hline
\end{tabular}

FONTE: VERISSSIMO, 2005.

Já o Conselho de Perus apresentou baixa participação em ambas esferas. Contudo, percebe-se que há um padrão de participação, e estes conselheiros acentuaram sua participação a partir de 2001. Entrevistaram-se neste Conselho os conselheiros Pe02, Pe03, P10 e Pe12. 
TABELA 11 - SELEÇÃO DOS CONSELHEIROS DE PERUS, 2005.

\begin{tabular}{|c|c|c|c|c|c|}
\hline \multicolumn{6}{|c|}{ Perus } \\
\hline \multirow[b]{2}{*}{ Conselheiro } & \multicolumn{3}{|c|}{ período de participação } & \multirow[b]{2}{*}{ total } & \multirow[b]{2}{*}{ IEP } \\
\hline & $\begin{array}{c}\text { período } \\
\text { anterior e/ou } \\
\text { até } 1980\end{array}$ & $\begin{array}{c}\text { entre } \\
1981 \text { até } \\
1992\end{array}$ & $\begin{array}{l}\text { a partir } \\
\text { de } 2001\end{array}$ & & \\
\hline Pe1 & & 1 & 2 & 3 & 0,25 \\
\hline $\mathrm{Pe} 2$ & 0 & 0 & 2 & 2 & 0,00 \\
\hline $\mathrm{Pe} 3$ & 0 & 1 & 2 & 3 & 0,25 \\
\hline Pe4 & 0 & 1 & 1 & 2 & 0,00 \\
\hline Pe5 & \multicolumn{5}{|c|}{ sem dados } \\
\hline Pe6 & \multicolumn{5}{|c|}{ sem dados } \\
\hline $\mathrm{Pe} 7$ & 0 & 2 & 3 & 5 & 0,75 \\
\hline Pe8 & 0 & 1 & 2 & 3 & 0,25 \\
\hline Pe9 & 0 & 2 & 2 & 4 & 0,50 \\
\hline Pe10 & 2 & 2 & 2 & 6 & 1,00 \\
\hline Pe11 & 0 & 3 & 2 & 5 & 0,75 \\
\hline Pe12 & 1 & 1 & 3 & 5 & 0,75 \\
\hline
\end{tabular}

FONTE: VERÍSSIMO, 2005. 


\section{b) VARIÁVEIS UTILIZADAS NA CONSTRUÇÃO DOS INDICADORES}

Para se calcular os indicadores, atribuíram-se pesos para as categorias de respostas. Para as respostas que indicavam mais ganho de capital social e cultura cívica por parte dos conselheiros foi atribuído peso maior (que variou de acordo com a questão).

Os totais das ponderações foram somados, e a soma destes resultados, por sua vez, compuseram os resultados dos indicadores. As ponderações feitas e suas respectivas somatórias podem ser vistas nas tabelas abaixo.

I) Indicador de Informação Geral

TABELA 01: FREQUÊNCIA DE USO DE FONTES DE INFORMAÇÃO GERAL UTILIZADAS PELOS CONSELHEIROS, POR CONSELHO QUE FAZ PARTE DE QUE FA PARTE.

Agora eu gostaria de saber sobre o uso que você faz de meios de comunicação como jornal, rádio e televisão. Com que freqüência você

\begin{tabular}{|c|c|c|c|c|c|c|}
\hline $\begin{array}{l}\text { Conselho } \\
\text { de que } \\
\text { faz parte }\end{array}$ & Veículo & $\begin{array}{l}\text { diariamente/quase } \\
\text { todos dias X4 }\end{array}$ & $\begin{array}{l}\text { algumas vezes } \\
\text { por semana X3 }\end{array}$ & $\begin{array}{c}\text { quase } \\
\text { nunca } \\
X 2 \\
\end{array}$ & $\begin{array}{l}\text { não tem o } \\
\text { hábito }\end{array}$ & Total \\
\hline \multirow{4}{*}{$\begin{array}{l}\frac{0}{2} \\
\frac{1}{0} \\
\frac{0}{2} \\
\frac{0}{2} \\
>\end{array}$} & TV & 4 & & & & 16 \\
\hline & Rádio & 3 & 1 & & & 15 \\
\hline & Jornal & 0 & 3 & & 1 & 9 \\
\hline & \multicolumn{5}{|l|}{ Total } & 40 \\
\hline & & & & & & \\
\hline \multirow{4}{*}{$\frac{\infty}{2}$} & TV & 3 & & 1 & & 14 \\
\hline & Rádio & 3 & 1 & & & 15 \\
\hline & Jornal & 4 & & & & 16 \\
\hline & & 45 \\
\hline
\end{tabular}




\begin{tabular}{|c|c|c|c|c|c|c|}
\hline \multicolumn{7}{|c|}{ conclusão } \\
\hline Conselho & Veículo & $\begin{array}{l}\text { diariamente/quase } \\
\text { todos dias X4 }\end{array}$ & $\begin{array}{l}\text { algumas vezes } \\
\text { por semana X3 }\end{array}$ & $\begin{array}{c}\text { quase } \\
\text { nunca } \\
\text { X2 }\end{array}$ & $\begin{array}{c}\text { não tem o } \\
\text { hábito }\end{array}$ & Total \\
\hline \multirow{4}{*}{ 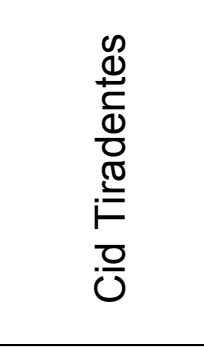 } & TV & 4 & & & & 16 \\
\hline & Rádio & 3 & 1 & & & 15 \\
\hline & Jornal & 1 & 1 & 2 & & 11 \\
\hline & \multicolumn{5}{|l|}{ Total } & 42 \\
\hline \multirow{4}{*}{ 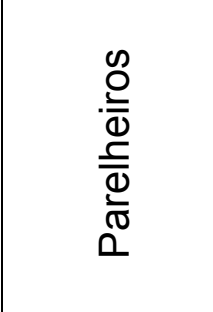 } & TV & 4 & & & & 16 \\
\hline & Rádio & 1 & & 1 & 2 & 6 \\
\hline & Jornal & 0 & 2 & 2 & & 10 \\
\hline & \multicolumn{5}{|l|}{ Total } & 32 \\
\hline
\end{tabular}

FONTE: VERISSIMO, J. 2005.

TABELA 1.1: FREQUÊNCIA DE USO DE FONTES DE INFORMAÇÃO GERAL UTILIZADAS PELOS CONSELHEIROS, POR PERÍODO DE INÍCIO DE PARTICIPAÇÃO.

\begin{tabular}{|c|c|c|c|c|c|c|}
\hline \multicolumn{7}{|c|}{$\begin{array}{c}\text { Agora eu gostaria de saber sobre o uso que você faz de meios de comunicação } \\
\text { como jornal, rádio e televisão. Com que freqüência você }\end{array}$} \\
\hline Período & Veículo & $\begin{array}{l}\text { diariamente/quase } \\
\text { todos dias X4 }\end{array}$ & $\begin{array}{l}\text { algumas vezes } \\
\text { por semana X3 }\end{array}$ & $\begin{array}{c}\text { quase } \\
\text { nunca X2 }\end{array}$ & $\begin{array}{l}\text { não tem o } \\
\text { hábito }\end{array}$ & Total \\
\hline \multirow{4}{*}{ 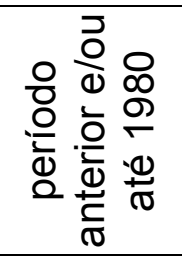 } & TV & 5 & & & & 20 \\
\hline & Rádio & 2 & 1 & & 2 & 11 \\
\hline & Jornal & 1 & 2 & 2 & & 14 \\
\hline & Total & & & & & 45 \\
\hline \multicolumn{7}{|c|}{ conclusão } \\
\hline
\end{tabular}




\begin{tabular}{|c|c|c|c|c|c|c|}
\hline Período & Veículo & $\begin{array}{l}\text { diariamente/quase } \\
\text { todos dias X4 }\end{array}$ & $\begin{array}{l}\text { algumas vezes } \\
\text { por semana X3 }\end{array}$ & $\begin{array}{c}\text { quase } \\
\text { nunca } X 2\end{array}$ & $\begin{array}{l}\text { não tem o } \\
\text { hábito }\end{array}$ & Total \\
\hline \multirow{4}{*}{ 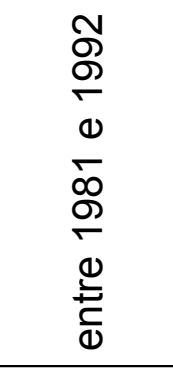 } & TV & 5 & & 1 & & 22 \\
\hline & Rádio & 4 & 1 & 1 & & 21 \\
\hline & Jornal & 2 & 2 & 2 & & 18 \\
\hline & \multicolumn{5}{|l|}{ Total } & 61 \\
\hline & & & & & & \\
\hline \multirow{4}{*}{$\begin{array}{l}\bar{\delta} \\
\stackrel{N}{0} \\
0 \\
0 \\
\frac{0}{0} \\
\frac{0}{0} \\
\frac{0}{0}\end{array}$} & TV & 5 & & & & 20 \\
\hline & Rádio & 4 & 1 & & & 19 \\
\hline & Jornal & 2 & 2 & & 1 & 14 \\
\hline & \multicolumn{5}{|l|}{ Total } & 53 \\
\hline
\end{tabular}

FONTE: VERISSIMO, J. 2005.

Como se vê nas tabelas acima, multiplicou-se o número de respondentes que afirmaram ver TV, ouvir rádio e ler jornal "diariamente ou quase todos os dias" por 04. Os conselheiros que disseram não ter o hábito de assistir à TV, escutar rádio ou ler jornal, não receberam ponderação, tendo sido agregado o número de respondentes $(\mathrm{N})$ aos demais valores ponderados.

Para uso da internet, levaram-se em consideração para ponderação os conselheiros que disseram utilizar-se deste veículo como fonte de informação ou entretenimento. A estes atribuiu-se um ponto, de modo que N, na categoria "sim", foi o valor total. 
TABELA 1.2 - USO DA INTERNET PELOS CONSELHEIROS, POR CONSELHO QUE FAZ PARTE.

\begin{tabular}{|l|c|c|c|}
\hline $\begin{array}{c}\text { Apesar de sabermos que o uso da Internet } \\
\text { ainda é pequeno, gostaríamos de Ihe } \\
\text { perguntar se você já usa a Internet? }\end{array}$ \\
\hline Conselho & sim X1 & não & Total \\
\hline VI Prudente & 1 & 3 & $\mathbf{1}$ \\
\hline Perus & 2 & 2 & $\mathbf{2}$ \\
\hline Cid Tiradentes & 1 & 3 & $\mathbf{1}$ \\
\hline Parelheiros & 1 & 3 & $\mathbf{1}$ \\
\hline Total & 5 & 11 & 5 \\
\hline
\end{tabular}

FONTE: VERÍSSIMO, J. 2005.

\section{TABELA 1.3 - USO DA INTERNET PELOS CONSELHEIROS, POR PERÍODO DE INÍCIO DE PARTICIPAÇÃO.}

\begin{tabular}{|l|c|c|c|}
\hline $\begin{array}{c}\text { Apesar de sabermos que o uso da Internet } \\
\text { ainda é pequeno, gostaríamos de Ihe } \\
\text { perguntar se você já usa a Internet? }\end{array}$ \\
\hline $\begin{array}{l}\text { Grupo } \\
\text { período anterior e/ou até } \\
1980\end{array}$ & 0 & 5 & $\mathbf{0}$ \\
\hline entre 1981-1992 & 4 & 2 & $\mathbf{4}$ \\
\hline depois de 2001 & 1 & 4 & $\mathbf{1}$ \\
\hline Total & 5 & 11 & 5 \\
\hline
\end{tabular}

FONTE: VERISSIMO, J. 2005.

\section{II) Indicador de Informação Política}

Para o indicador de informação política o processo foi o mesmo, atribuiu-se peso 03 para os conselheiros que declararam sempre utilizar-se de veículos de informação política, peso 02 para os que declararam fazer uso destes veículos às vezes, e um para os que disseram utilizá-los raramente. 
TABELA 02: FREQUÊNCIA DO USO DE FONTES DE INFORMAÇÕES POLÍTICAS, POR CONSELHO QUE FAZ PARTE.

\begin{tabular}{|c|c|c|c|c|c|c|}
\hline \multicolumn{7}{|c|}{$\begin{array}{l}\text { Vou ler uma lista de atividades e gostaria de saber com qual freqüência você as } \\
\text { faz. Com que freqüência você }\end{array}$} \\
\hline $\begin{array}{l}\stackrel{0}{c} \\
\bar{\phi} \\
\mathscr{n} \\
\overline{0} \\
0\end{array}$ & Atividade & $\begin{array}{l}\text { Assiste } \\
\text { noticiário na } \\
\text { TV }\end{array}$ & $\begin{array}{l}\text { Lê sobre } \\
\text { política } \\
\text { nos } \\
\text { jornais }\end{array}$ & $\begin{array}{l}\text { Conversa sobre } \\
\text { política com os } \\
\text { amigos }\end{array}$ & $\begin{array}{l}\text { Participa de } \\
\text { reuniões para } \\
\text { discutir questões } \\
\text { políticas }\end{array}$ & Total \\
\hline \multirow{5}{*}{$\begin{array}{l}\stackrel{0}{\frac{1}{2}} \\
\frac{0}{0} \\
\frac{2}{2} \\
\frac{2}{>}\end{array}$} & sempre X3 & 3 & 2 & 4 & 1 & 30 \\
\hline & às vezes $X 2$ & & 1 & & 1 & 4 \\
\hline & $\begin{array}{l}\text { raramente } \\
\mathrm{X} 1\end{array}$ & 1 & & & & 1 \\
\hline & nunca & & 1 & & 2 & 0 \\
\hline & \multicolumn{5}{|l|}{ Total } & 35 \\
\hline \multirow{5}{*}{ 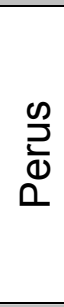 } & sempre X3 & 2 & 1 & 1 & 2 & 18 \\
\hline & às vezes $\mathrm{X} 2$ & 1 & 1 & 2 & & 8 \\
\hline & $\begin{array}{l}\text { raramente } \\
\mathrm{X} 1\end{array}$ & 1 & 1 & & 1 & 3 \\
\hline & nunca & & 1 & 1 & 1 & 0 \\
\hline & \multicolumn{5}{|l|}{ Total } & 29 \\
\hline & & & & & & \\
\hline \multirow{5}{*}{ 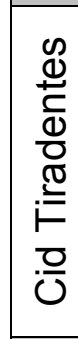 } & sempre $\mathrm{X} 3$ & 3 & 1 & 3 & 3 & 30 \\
\hline & às vezes $X 2$ & & & & & 0 \\
\hline & $\begin{array}{l}\text { raramente } \\
\text { X1 }\end{array}$ & 1 & 3 & & & 4 \\
\hline & nunca & & & 1 & 1 & 0 \\
\hline & \multicolumn{5}{|l|}{ Total } & 34 \\
\hline \multirow{5}{*}{ 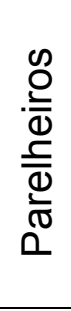 } & sempre X3 & 4 & 4 & 4 & 1 & 39 \\
\hline & às vezes $X 2$ & & & & 2 & 4 \\
\hline & $\begin{array}{l}\text { raramente } \\
\mathrm{X} 1\end{array}$ & & & & 1 & 1 \\
\hline & nunca & & & & & 0 \\
\hline & \multicolumn{5}{|l|}{ Total } & 44 \\
\hline
\end{tabular}

FONTE: VERÍSSIMO, J. 2005. 
TABELA 2.1: FREQUÊNCIA DO USO DE FONTES DE INFORMAÇÕES POLÍTICAS, POR PERÍODO DE INÍCIO DE PARTICIPAÇÃO.

\begin{tabular}{|c|c|c|c|c|c|c|}
\hline \multicolumn{7}{|c|}{$\begin{array}{c}\text { Vou ler uma lista de atividades e gostaria de saber com qual freqüência você as faz. } \\
\text { Com que freqüência você }\end{array}$} \\
\hline $\begin{array}{l}\frac{0}{8} \\
\frac{0}{0} \\
\frac{0}{0}\end{array}$ & Atividade & $\begin{array}{l}\text { Assiste } \\
\text { noticiário na } \\
\text { TV }\end{array}$ & $\begin{array}{l}\text { Lê sobre } \\
\text { política nos } \\
\text { jornais }\end{array}$ & $\begin{array}{l}\text { Conversa sobre } \\
\text { política com os } \\
\text { amigos }\end{array}$ & $\begin{array}{l}\text { Participa de } \\
\text { reuniões para } \\
\text { discutir } \\
\text { questões } \\
\text { políticas } \\
\end{array}$ & Total \\
\hline \multirow{5}{*}{ 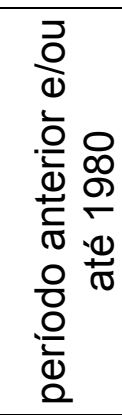 } & $\begin{array}{l}\text { sempre } \\
\text { X3 }\end{array}$ & 4 & 4 & 5 & 2 & 45 \\
\hline & \begin{tabular}{|l|} 
às vezes \\
X2
\end{tabular} & & & & 3 & 6 \\
\hline & $\begin{array}{l}\text { raramente } \\
\text { X1 }\end{array}$ & 1 & 1 & & & 2 \\
\hline & nunca & & & & & 0 \\
\hline & \multicolumn{5}{|l|}{ Total } & 53 \\
\hline \multirow{6}{*}{ 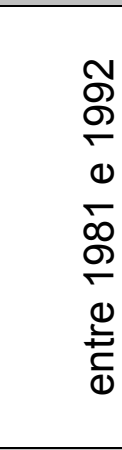 } & & & & & & \\
\hline & $\begin{array}{l}\text { sempre } \\
\text { X3 }\end{array}$ & 4 & 3 & 5 & 5 & 51 \\
\hline & $\begin{array}{l}\text { às vezes } \\
\text { X2 }\end{array}$ & 1 & 2 & 1 & & 8 \\
\hline & $\begin{array}{l}\text { raramente } \\
\text { X1 }\end{array}$ & 1 & 1 & & 1 & 3 \\
\hline & nunca & & & & & 0 \\
\hline & \multicolumn{5}{|l|}{ Total } & 62 \\
\hline & & & & & & \\
\hline \multirow{4}{*}{$\begin{array}{l}\bar{\delta} \\
\stackrel{0}{0} \\
0 \\
0 \\
\frac{0}{0} \\
\frac{0}{0} \\
\frac{0}{0}\end{array}$} & $\begin{array}{l}\text { sempre } \\
\text { X3 }\end{array}$ & 4 & 1 & 2 & & 21 \\
\hline & \begin{tabular}{l|} 
às vezes \\
$\mathrm{X} 2$
\end{tabular} & & & 1 & & 2 \\
\hline & $\begin{array}{l}\text { raramente } \\
\mathrm{X} 1\end{array}$ & 1 & 2 & & 1 & 3 \\
\hline & nunca & & 2 & 2 & 4 & 0 \\
\hline
\end{tabular}

FONTE: VERISSSIMO, J. 2005. 


\section{III) Indicador de Valores Sócio-Políticos}

Para construir o indicador de valores sócio-políticos dos entrevistados, determinou-se um fator multiplicador 02 para o número de conselheiros que declararam já terem passado pelas experiências abaixo, e um para os que declararam poder fazê-las um dia.

TABELA 03: GRAU DE ATIVIDADE POLÍTICA, POR CONSELHO QUE FAZ PARTE.

\begin{tabular}{|c|c|c|c|c|c|c|c|}
\hline \multicolumn{8}{|c|}{$\begin{array}{l}\text { Vou ler algumas diferentes formas de ação política que as pessoas podem adotar. } \\
\text { Gostaria que você dissesse se já fez alguma dessas ações, se você poderia fazê- } \\
\text { las, ou se nunca, em nenhuma circunstância, faria. }\end{array}$} \\
\hline Conselho & Atividade & $\begin{array}{l}\text { Assinar um } \\
\text { manifesto }\end{array}$ & $\begin{array}{l}\text { Participar } \\
\text { de boicote }\end{array}$ & \begin{tabular}{|l|} 
Participar de \\
manifestações
\end{tabular} & $\begin{array}{l}\text { Participar } \\
\text { de greves }\end{array}$ & $\begin{array}{l}\text { Ocupar } \\
\text { prédios }\end{array}$ & Total \\
\hline \multirow{4}{*}{$\begin{array}{l}\text { VI } \\
\text { Prudente }\end{array}$} & Já fez $\quad X 2$ & 3 & 1 & 2 & & & 12 \\
\hline & $\begin{array}{c}\text { Poderia fazer } \\
\text { X1 }\end{array}$ & 1 & 2 & & 2 & 1 & 6 \\
\hline & Nunca faria & & 1 & 2 & 2 & 3 & 0 \\
\hline & \multicolumn{6}{|l|}{ Total } & 18 \\
\hline \multirow{5}{*}{ Perus } & ló foz X? & 3 & 2 & 2 & 1 & 1 & 18 \\
\hline & Poderia fazer & & & & & & \\
\hline & $\mathrm{X} 1$ & & 2 & 1 & 2 & 1 & 6 \\
\hline & Nunca faria & 1 & & 1 & 1 & 2 & 0 \\
\hline & \multicolumn{6}{|l|}{ Total } & 24 \\
\hline \multirow{5}{*}{$\begin{array}{l}\text { Cid } \\
\text { Tiradentes }\end{array}$} & & & & & & & \\
\hline & Já fez X2 & 3 & 1 & 4 & 4 & & 24 \\
\hline & $\begin{array}{l}\text { Poderia fazer } \\
\text { X1 }\end{array}$ & 1 & 3 & & & 1 & 5 \\
\hline & Nunca faria & & & & & 3 & 0 \\
\hline & \multicolumn{6}{|l|}{ Total } & 29 \\
\hline \multirow{4}{*}{ Parelheiros } & Já fez X2 & 3 & 1 & 4 & 3 & 1 & 24 \\
\hline & Poderia fazer & & & & & & 2 \\
\hline & & 1 & $\frac{2}{1}$ & & & & 2 \\
\hline & \multicolumn{6}{|l|}{ Total } & 26 \\
\hline
\end{tabular}

FONTE: VERISSIMO, J. 2005. 
TABELA 3.1: GRAU DE ATIVIDADE POLÍTICA, POR PERÍODO DE INÍCIO DE PARTICIPAÇÃO.

\begin{tabular}{|c|c|c|c|c|c|c|c|}
\hline \multicolumn{8}{|c|}{$\begin{array}{c}\text { Vou ler algumas diferentes formas de ação política que as pessoas podem adotar. } \\
\text { Gostaria que você dissesse se já fez alguma dessas ações, se você poderia fazê-las, } \\
\text { ou se nunca, em nenhuma circunstância, faria. }\end{array}$} \\
\hline Período & Atividade & $\begin{array}{l}\text { Assinar um } \\
\text { manifesto }\end{array}$ & $\begin{array}{l}\text { Participar } \\
\text { de boicote }\end{array}$ & \begin{tabular}{|l|} 
Participar de \\
manifestações
\end{tabular} & $\begin{array}{l}\text { Participar de } \\
\text { greves }\end{array}$ & $\begin{array}{l}\text { Ocupar } \\
\text { prédios }\end{array}$ & Total \\
\hline \multirow{4}{*}{$\begin{array}{l}\text { período } \\
\text { anterior } \\
\text { e/ou até } \\
1980\end{array}$} & Já fez X2 & 3 & 2 & 5 & 3 & 1 & 28 \\
\hline & \begin{tabular}{|c} 
Poderia fazer \\
X1 \\
\end{tabular} & 1 & 2 & & 1 & & 4 \\
\hline & Nunca faria & 1 & 1 & & 1 & 4 & 0 \\
\hline & \multicolumn{6}{|l|}{ Total } & 32 \\
\hline \multirow{4}{*}{$\begin{array}{l}\text { entre } \\
1981 \text { e } \\
1992\end{array}$} & Já fez X2 & 6 & 2 & 6 & 4 & 1 & 38 \\
\hline & \begin{tabular}{|c} 
Poderia fazer \\
X1 \\
\end{tabular} & & 4 & & 2 & 3 & 9 \\
\hline & Nunca faria & & & & & 2 & 0 \\
\hline & \multicolumn{6}{|l|}{ Total } & 47 \\
\hline \multirow{4}{*}{$\begin{array}{l}\text { depois } \\
\text { de } 2001\end{array}$} & Já fez X2 & 3 & 1 & 1 & 1 & & 12 \\
\hline & $\begin{array}{c}\text { Poderia fazer } \\
\text { X1 } \\
\end{array}$ & 1 & 3 & 1 & 1 & & 6 \\
\hline & Nunca faria & 1 & 1 & 3 & 3 & 5 & 0 \\
\hline & \multicolumn{6}{|l|}{ Total } & 18 \\
\hline
\end{tabular}

FONTE: VERÍSSIMO, J. 2005.

Os julgamentos feitos pelos conselheiros acerca do melhor tipo de regime político foram ponderados de forma que aqueles que declararam ser o regime democrático "muito bom" ou "bom" tiveram suas respostas multiplicadas por dois. Para aqueles que disseram preferir um líder forte que não tenha que se preocupar com o Congresso, ter técnicos especialistas governando ou ainda aqueles que afirmaram que ter um governo militar seria o melhor regime, foram considerados nulos para este indicador. 
TABELA 3.2: VALORES DEMOCRÁTICOS, POR CONSELHO QUE FAZ PARTE.

\begin{tabular}{|c|c|c|c|c|c|c|}
\hline \multicolumn{7}{|c|}{ O que você pensa de cada uma dessas maneiras de governar um país? } \\
\hline Conselho & Atividade & $\begin{array}{c}\text { líder que não } \\
\text { tenha que se } \\
\text { preocupar } \\
\text { com o } \\
\text { Congresso } \\
\text { X0 }\end{array}$ & $\begin{array}{c}\text { Técnicos } \\
\text { especialistas } \\
\text { governando } \\
\text { X0 }\end{array}$ & $\begin{array}{c}\text { Ter } \\
\text { governo } \\
\text { militar } \\
\text { X0 }\end{array}$ & $\begin{array}{c}\text { Ter regime } \\
\text { democrático } \\
\text { X2 }\end{array}$ & Total \\
\hline \multirow{4}{*}{$\begin{array}{l}\mathrm{Vl} \\
\text { Prudente }\end{array}$} & Muito boa & 1 & & 1 & 2 & \multirow{4}{*}{8} \\
\hline & Boa & & 1 & & 2 & \\
\hline & Ruim & 1 & 3 & 1 & & \\
\hline & Muito Ruim & 2 & & 2 & & \\
\hline \multirow{4}{*}{ Perus } & Muito boa & & & 2 & 1 & \multirow{4}{*}{8} \\
\hline & Boa & 1 & 4 & & 3 & \\
\hline & Ruim & & & & & \\
\hline & Muito Ruim & 3 & & 2 & & \\
\hline \multirow{4}{*}{$\begin{array}{l}\text { Cid } \\
\text { Tiradentes }\end{array}$} & Muito boa & & & 1 & 1 & \multirow{4}{*}{8} \\
\hline & Boa & 2 & 3 & & 3 & \\
\hline & Ruim & 1 & & 1 & & \\
\hline & Muito Ruim & 1 & 1 & 2 & & \\
\hline \multirow{4}{*}{ Parelheiros } & Muito boa & & 1 & & 1 & \multirow{4}{*}{8} \\
\hline & Boa & 1 & 2 & & 3 & \\
\hline & Ruim & & & 3 & & \\
\hline & Muito Ruim & 3 & 1 & 1 & & \\
\hline
\end{tabular}

FONTE: VERISSSIMO, J. 2005.

TABELA 3.3: VALORES DEMOCRÁTICOS, POR PERÍODO DE INÍCIO DE PARTICIPAÇÃO.

\begin{tabular}{|c|c|c|c|c|c|c|}
\hline \multicolumn{7}{|c|}{ O que você pensa de cada uma dessas maneiras de governar um país? } \\
\hline Período & Atividade & $\begin{array}{c}\text { líder que não } \\
\text { tenha que se } \\
\text { preocupar com } \\
\text { o Congresso } \\
\text { X0 }\end{array}$ & $\begin{array}{c}\text { Técnicos } \\
\text { especialistas } \\
\text { governando } \\
\text { X0 }\end{array}$ & $\begin{array}{c}\text { Ter } \\
\text { govern } \\
0 \\
\text { militar } \\
\text { X0 }\end{array}$ & $\begin{array}{c}\text { Ter regime } \\
\text { democrático } \mathrm{X} \\
2\end{array}$ & Total \\
\hline \multirow{4}{*}{$\begin{array}{l}\text { Período anterior } \\
\text { e/ou até } 1980\end{array}$} & Muito boa & 0 & & & 3 & \multirow{4}{*}{10} \\
\hline & Boa & 1 & 3 & 1 & 2 & \\
\hline & Ruim & 0 & & 1 & & \\
\hline & Muito Ruim & 4 & 2 & 3 & & \\
\hline \multirow{4}{*}{ entre 1981 e 1992} & Muito boa & 0 & 1 & & 1 & \multirow{4}{*}{12} \\
\hline & Boa & 2 & 4 & & 5 & \\
\hline & Ruim & 1 & 1 & 3 & & \\
\hline & Muito Ruim & 3 & & 3 & & \\
\hline
\end{tabular}




\begin{tabular}{|c|c|c|c|c|c|c|}
\hline \multicolumn{7}{|c|}{ conclusão } \\
\hline Período & Atividade & $\begin{array}{c}\text { líder que não } \\
\text { tenha que se } \\
\text { preocupar com } \\
\text { o Congresso } \\
\text { X0 }\end{array}$ & $\begin{array}{c}\text { Técnicos } \\
\text { especialistas } \\
\text { governando } \\
\text { X0 }\end{array}$ & $\begin{array}{c}\text { Ter } \\
\text { governo } \\
\text { militar } \\
\text { X0 }\end{array}$ & $\begin{array}{c}\text { Ter regime } \\
\text { democrático } \\
\text { X } 2\end{array}$ & Total \\
\hline \multirow{4}{*}{ depois de 2001} & Muito boa & 1 & & & 1 & \multirow{4}{*}{10} \\
\hline & Boa & 1 & 3 & 3 & 4 & \\
\hline & Ruim & 1 & 2 & 1 & & \\
\hline & Muito Ruim & 2 & & 1 & & \\
\hline
\end{tabular}

FONTE: VERÍSSIMO, J. 2005.

À preferência pelo regime democrático, calculada acima, somaram-se - para a categoria "valores democráticos" do indicador de valores sócio-políticos (tabela 03 capítulo 04) - os conselheiros que se disseram muito orgulhosos de serem brasileiros. As respostas destes foram multiplicadas por três, os que se disseram orgulhosos por dois, e os não muito orgulhosos por um. Não houve casos de conselheiros que afirmaram não serem orgulhosos.

TABELA 3.4: ORGULHO NACIONAL, POR CONSELHO QUE FAZ PARTE.

\begin{tabular}{|l|c|c|c|c|}
\hline \multicolumn{5}{|c|}{ E em relação a ser brasileiro(a)? Como você se considera? } \\
\hline Conselho & $\begin{array}{c}\text { muito } \\
\text { orgulhoso X3 }\end{array}$ & orgulhoso X2 & $\begin{array}{c}\text { não muito orgulhoso } \\
\text { X1 }\end{array}$ & Total \\
\hline VI Prudente & 4 & & & $\mathbf{1 2}$ \\
\hline Perus & 1 & 2 & 1 & $\mathbf{8}$ \\
\hline $\begin{array}{l}\text { Cid } \\
\text { Tiradentes }\end{array}$ & 1 & 2 & 1 & $\mathbf{8}$ \\
\hline Parelheiros & & 3 & 1 & $\mathbf{7}$ \\
\hline
\end{tabular}

FONTE: VERISSIMO, J. 2005.

TABELA 3.5: ORGULHO NACIONAL, POR PERÍODO DE INÍCIO DE PARTICIPAÇÃO.

\begin{tabular}{|l|c|c|c|c|}
\hline \multicolumn{5}{|c|}{ E em relação a ser brasileiro(a)? Como você se considera? } \\
\hline Período & $\begin{array}{c}\text { muito orgulhoso } \\
\text { X3 }\end{array}$ & $\begin{array}{c}\text { orgulhoso } \\
\text { X2 }\end{array}$ & $\begin{array}{c}\text { não muito orgulhoso } \\
\text { X1 }\end{array}$ & Total \\
\hline $\begin{array}{l}\text { período anterior } \\
\text { e/ou até 1980 }\end{array}$ & 1 & 2 & 2 & 9 \\
\hline $\begin{array}{l}\text { entre 1981 e } \\
1992\end{array}$ & 1 & 4 & 1 & 12 \\
\hline depois de 2001 & 4 & 1 & 0 & 14 \\
\hline
\end{tabular}

FONTE: VERÍSSIMO, J. 2005. 
Para os sentimentos que os conselheiros declararam nutrir em relação à política foi somado um ponto a cada respondente que se disse entusiasmado, interessado, apaixonado ou comprometido.

TABELA 3.6: SENTIMENTO EM RELAÇÃO À POLÍTICA, POR CONSELHO QUE FAZ PARTE.

\begin{tabular}{|l|c|c|c|c|c|c|c|}
\hline \multicolumn{6}{|c|}{ Todos temos diferentes sentimentos em relação à política. Em você, a política causa } \\
\hline Conselho & $\begin{array}{c}\text { entusiasmo } \\
+1\end{array}$ & $\begin{array}{c}\text { interesse } \\
+1\end{array}$ & $\begin{array}{c}\text { paixão } \\
+1\end{array}$ & desgosto & $\begin{array}{c}\text { Compromisso } \\
+1\end{array}$ & desconfiança & Total \\
\hline VI Prudente & 2 & & 1 & & & 1 & $\mathbf{3}$ \\
\hline Perus & & 1 & & & 1 & 2 & $\mathbf{2}$ \\
\hline $\begin{array}{l}\text { Cid } \\
\text { Tiradentes }\end{array}$ & 1 & & & 1 & 2 & & 3 \\
\hline Parelheiros & 1 & 1 & & & 2 & & $\mathbf{4}$ \\
\hline
\end{tabular}

FONTE: VERÍSSIMO, J. 2005.

\section{TABELA 3.7: SENTIMENTO EM RELAÇÃO À POLÍTICA, POR PERÍODO DE INÍCIO DE PARTICIPAÇÃO.}

\begin{tabular}{|l|c|c|c|c|c|c|c|}
\hline \multicolumn{7}{|c|}{ Todos temos diferentes sentimentos em relação à política. Em você, a política causa } \\
\hline Período & $\begin{array}{c}\text { entusiasmo } \\
+1\end{array}$ & $\begin{array}{c}\text { interesse } \\
+1\end{array}$ & $\begin{array}{c}\text { paixão } \\
+1\end{array}$ & desgosto & $\begin{array}{c}\text { Compromisso } \\
+1\end{array}$ & desconfiança & Total \\
\hline $\begin{array}{l}\text { período } \\
\text { anterior } \\
\text { e/ou até } \\
1980\end{array}$ & 3 & 2 & 2 & & & 5 \\
\hline $\begin{array}{l}\text { entre } \\
1981 \text { e } \\
1992\end{array}$ & 1 & 1 & 1 & & & 6 \\
\hline $\begin{array}{l}\text { depois de } \\
2001\end{array}$ & & 2 & 1 & 1 & 5 & 3 & 1 \\
\hline Total & 4 & 2 & & & & 3 & 12 \\
\hline
\end{tabular}

FONTE: VERISSIMO, J. 2005

IV) Indicador de Participação e Associativismo

Para este indicador, a quantidade de conselheiros $(\mathrm{N})$ que declararam fazer parte formalmente de associações tiveram suas respostas multiplicadas por 
quatro. Já os que afirmaram participar esporadicamente destas instituições tiveram suas respostas multiplicadas por três. Os conselheiros que disseram já ter feito parte de instituições participativas e não fazer mais, foram ponderados por dois.

\section{TABELA 04: NÚMERO DE ASSOCIAÇÕES DAS QUAIS FAZEM PARTE OS CONSELHEIROS DE VILA PRUDENTE.}

\begin{tabular}{|l|c|c|c|c|}
\hline \multicolumn{3}{|c|}{ Vila Prudente - Você participa de: } \\
\hline Associação / escala & $\begin{array}{c}\text { formalmente } \\
\text { X4 }\end{array}$ & $\begin{array}{c}\text { esporadicamente } \\
\text { X3 }\end{array}$ & $\begin{array}{c}\text { já } \\
\text { participei } \\
\text { X2 }\end{array}$ & Total \\
\hline Entidade beneficente & 1 & & & 3 \\
\hline Associação recreativa/esportiva & & 1 & & 2 \\
\hline Associação de defesa dos Direitos Humanos & 1 & 1 & & 5 \\
\hline Defesa dos Consumidores & & & & 5 \\
\hline Associação religiosa & 1 & 1 & & 3 \\
\hline Grupos de Fé e política & 1 & & 1 & 2 \\
\hline Associações de Moradia & & 1 & & 9 \\
\hline Partido Político & 1 & 1 & & 2 \\
\hline Associação de Saúde & 3 & & & 0 \\
\hline Associação ligada a educação & & & & 0 \\
\hline Associação de meio ambiente & & & & 0 \\
\hline Associação de cultura & & & & 0 \\
\hline Entidade empresarial/patronal & & & & 0 \\
\hline Entidade estudantil & & & & 2 \\
\hline Associação de auto-ajuda & & & 1 & $\mathbf{5 5}$ \\
\hline Sindicato de trabalhadores & & & & \\
\hline Associação profissional & & & & \\
\hline Outros tipos de associações & & & & \\
\hline Total & & & & \\
\hline
\end{tabular}

FONTE: VERÍSSIMO, J. 2005.

\section{TABELA 4.1: NÚMERO DE ASSOCIAÇÕES DAS QUAIS FAZEM PARTE OS CONSELHEIROS DE PERUS.}

\begin{tabular}{|l|c|c|c|c|}
\hline \multicolumn{4}{|c|}{ Perus - Você participa de: } \\
\hline Associação / escala & $\begin{array}{c}\text { formalmente } \\
X 4\end{array}$ & $\begin{array}{c}\text { esporadicamente } \\
X 3\end{array}$ & $\begin{array}{c}\text { já } \\
\text { participei } \\
X 2\end{array}$ & Total \\
\hline Entidade beneficente & 1 & & 1 & 6 \\
\hline Associação recreativa/esportiva & & 1 & & 3 \\
\hline Associação de defesa dos Direitos Humanos & 1 & & 1 & 6 \\
\hline Defesa dos Consumidores & & & & 0 \\
\hline Associação religiosa & & 1 & & 3 \\
\hline Grupos de Fé e política & 2 & & & 8 \\
\hline
\end{tabular}




\begin{tabular}{|l|c|c|c|c|}
\hline \multicolumn{5}{|c|}{ conclusão } \\
\hline Associação / escala & $\begin{array}{c}\text { formalmente } \\
X 4\end{array}$ & $\begin{array}{c}\text { esporadicamente } \\
X 3\end{array}$ & $\begin{array}{c}\text { já } \\
\text { participei } \\
X 2\end{array}$ & Total \\
\hline Associações de Moradia & & 1 & & 3 \\
\hline Partido Político & & 1 & 1 & 5 \\
\hline Associação de Saúde & 3 & & & 12 \\
\hline Associação ligada a educação & & 1 & & 3 \\
\hline Associação de meio ambiente & & 2 & & 6 \\
\hline Associação de cultura & 1 & & & 4 \\
\hline Entidade empresarial/patronal & & & & 0 \\
\hline Entidade estudantil & & & & 0 \\
\hline Associação de auto-ajuda & & & & 7 \\
\hline Sindicato de trabalhadores & 1 & 1 & & 4 \\
\hline Associação profissional & 1 & & & $\mathbf{7 4}$ \\
\hline Outros tipos de associações & 1 & & & \\
\hline Total & 11 & 8 & & \\
\hline
\end{tabular}

FONTE: VERÍSSIMO, J. 2005.

TABELA 4.2: NÚMERO DE ASSOCIAÇÕES DAS QUAIS FAZEM PARTE OS CONSELHEIROS DE CIDADE TIRADENTES.

\begin{tabular}{|l|c|c|c|c|}
\hline \multicolumn{4}{|c|}{ Cidade Tiradentes - Você participa de: } \\
\hline Associação / escala & $\begin{array}{c}\text { formalmente } \\
\text { X4 }\end{array}$ & $\begin{array}{c}\text { esporadicamente } \\
\text { X3 }\end{array}$ & $\begin{array}{c}\text { já } \\
\text { participei } \\
\text { X2 }\end{array}$ & Total \\
\hline Entidade beneficente & 1 & & & 4 \\
\hline Associação recreativa/esportiva & & 1 & & 3 \\
\hline Associação de defesa dos Direitos Humanos & 1 & 1 & & 7 \\
\hline Defesa dos Consumidores & & & & 8 \\
\hline Associação religiosa & 2 & & & 10 \\
\hline Grupos de Fé e política & 1 & 2 & & 7 \\
\hline Associações de Moradia & 1 & 1 & & 8 \\
\hline Partido Político & 2 & 1 & & 11 \\
\hline Associação de Saúde & 2 & & & 3 \\
\hline Associação ligada a educação & 2 & 1 & & 3 \\
\hline Associação de meio ambiente & & 1 & & 0 \\
\hline Associação de cultura & & 1 & & 0 \\
\hline Entidade empresarial/patronal & & & & 4 \\
\hline Entidade estudantil & & & & 0 \\
\hline Associação de auto-ajuda & & & 1 & 2 \\
\hline Sindicato de trabalhadores & 12 & 9 & $\mathbf{8 1}$ \\
\hline Associação profissional & & & & \\
\hline Outros tipos de associações & & & & \\
\hline Total & & & & \\
\hline
\end{tabular}

FONTE: VERÍSSIMO, J. 2005. 


\section{TABELA 4.2: NÚMERO DE ASSOCIAÇÕES DAS QUAIS FAZEM PARTE OS CONSELHEIROS DE PARELHEIROS.}

\begin{tabular}{|l|c|c|c|c|}
\hline \multicolumn{4}{|c|}{ Parelheiros - Você participa de: } \\
\hline Associação / escala & $\begin{array}{c}\text { formalmente } \\
\text { X4 }\end{array}$ & $\begin{array}{c}\text { esporadicamente } \\
\text { X3 }\end{array}$ & $\begin{array}{c}\text { já } \\
\text { participei } \\
\text { X2 }\end{array}$ & Total \\
\hline Entidade beneficente & 1 & & & 4 \\
\hline Associação recreativa/esportiva & 1 & & & 4 \\
\hline Associação de defesa dos Direitos Humanos & 1 & 2 & & 4 \\
\hline Defesa dos Consumidores & 1 & & & 8 \\
\hline Associação religiosa & 2 & & 2 & 8 \\
\hline Grupos de Fé e política & 1 & & & 12 \\
\hline Associações de Moradia & 3 & & & 6 \\
\hline Partido Político & & & & 0 \\
\hline Associação de Saúde & & & & 9 \\
\hline Associação ligada a educação & 1 & & & 0 \\
\hline Associação de meio ambiente & & & & 0 \\
\hline Associação de cultura & & & & 0 \\
\hline Entidade empresarial/patronal & & & & 0 \\
\hline Entidade estudantil & & & & 4 \\
\hline Associação de auto-ajuda & & & & 0 \\
\hline Sindicato de trabalhadores & & & 5 & $\mathbf{7 8}$ \\
\hline Associação profissional & & & & \\
\hline Outros tipos de associações & & & & \\
\hline Total & & & & \\
\hline
\end{tabular}

FONTE: VERÍSSIMO, J. 2005.

TABELA 4.3: NÚMERO DE ASSOCIAÇÕES DAS QUAIS FAZEM PARTE OS CONSELHEIROS QUE INICIARAM SUA PARTICIPAÇÃO PERÍODO ANTERIOR E/OU ATÉ 1980.

\section{período anterior e/ou até 1980 - Você participa de:}

Associação / escala

Entidade beneficente

Associação recreativa/esportiva

Associação de defesa dos Direitos Humanos

Defesa dos Consumidores

Associação religiosa

Grupos de Fé e política

Associações de Moradia

Partido Político

Associação de Saúde

Associação ligada a educação

Associação de meio ambiente

Associação de cultura

Entidade empresarial/patronal

\begin{tabular}{|c|c|c|c|}
\hline $\begin{array}{c}\text { formalmente } \\
X 4\end{array}$ & $\begin{array}{c}\text { esporadicamente } \\
X 3\end{array}$ & $\begin{array}{c}j a ́ \\
\text { participei } \\
X 2\end{array}$ & Total \\
\hline 1 & & 1 & 6 \\
\hline 2 & & & 0 \\
\hline 1 & 2 & & 14 \\
\hline 3 & 1 & & 4 \\
\hline 2 & 2 & & 15 \\
\hline 1 & & & 14 \\
\hline 1 & 2 & 2 & 14 \\
\hline 2 & & & 8 \\
\hline 2 & 1 & 1 & 13 \\
\hline & 3 & & 9 \\
\hline & & & 0 \\
\hline & & & 0 \\
\hline
\end{tabular}




\begin{tabular}{|l|c|c|c|c|}
\hline \multicolumn{5}{|c|}{ conclusão } \\
\hline Associação / escala & $\begin{array}{c}\text { formalmente } \\
X 4\end{array}$ & $\begin{array}{c}\text { esporadicamente } \\
X 3\end{array}$ & $\begin{array}{c}\text { já } \\
\text { participei } \\
X 2\end{array}$ & Total \\
\hline Entidade estudantil & & & & 0 \\
\hline Associação de auto-ajuda & & & & 0 \\
\hline Sindicato de trabalhadores & 1 & & 3 & 10 \\
\hline Associação profissional & 1 & & & 4 \\
\hline Outros tipos de associações & 1 & & 1 & 6 \\
\hline Total & 18 & 11 & 8 & $\mathbf{1 2 1}$ \\
\hline
\end{tabular}

FONTE: VERÍSSIMO, J. 2005.

\section{TABELA 4.4: NÚMERO DE ASSOCIAÇÕES DAS QUAIS FAZEM PARTE OS CONSELHEIROS QUE INICIARAM SUA PARTICIPAÇÃO ENTRE 1981 E 1992.}

\begin{tabular}{|c|c|c|c|c|}
\hline \multicolumn{5}{|c|}{ entre 1981 e 1992 - Você participa de: } \\
\hline Associação / escala & $\begin{array}{c}\text { formalmente } \\
\text { X4 }\end{array}$ & $\begin{array}{c}\text { esporadicamente } \\
\text { X3 }\end{array}$ & $\begin{array}{c}\text { já } \\
\text { participei } \\
X 2\end{array}$ & Total \\
\hline Entidade beneficente & 2 & & 1 & 10 \\
\hline Associação recreativa/esportiva & 1 & 1 & & 7 \\
\hline Associação de defesa dos Direitos Humanos & 2 & 2 & & 14 \\
\hline Defesa dos Consumidores & & & & 0 \\
\hline Associação religiosa & 4 & & & 16 \\
\hline Grupos de Fé e política & 3 & 2 & & 18 \\
\hline Associações de Moradia & 2 & 3 & & 17 \\
\hline Partido Político & 2 & 3 & & 17 \\
\hline Associação de Saúde & 3 & & & 12 \\
\hline Associação ligada a educação & 1 & 2 & 1 & 15 \\
\hline Associação de meio ambiente & & 3 & & 9 \\
\hline Associação de cultura & 1 & 1 & & 7 \\
\hline Entidade empresarial/patronal & & & & 0 \\
\hline Entidade estudantil & & & & 0 \\
\hline Associação de auto-ajuda & & & & 0 \\
\hline Sindicato de trabalhadores & & & & 0 \\
\hline Associação profissional & & 1 & 1 & 5 \\
\hline Outros tipos de associações & & & & 0 \\
\hline Total & 21 & 18 & 3 & 144 \\
\hline
\end{tabular}

FONTE: VERÍSSIMO, J. 2005. 
TABELA 4.5: NÚMERO DE ASSOCIAÇÕES DAS QUAIS FAZEM PARTE OS CONSELHEIROS QUE INICIARAM SUA PARTICIPAÇÃO DEPOIS DE 2001.

\begin{tabular}{|l|c|c|c|c|}
\hline \multicolumn{5}{|c|}{ depois de 2001 - Você participa de: } \\
\hline Associação / escala & $\begin{array}{c}\text { formalmente } \\
\text { X4 }\end{array}$ & $\begin{array}{c}\text { esporadicamente } \\
\text { X3 }\end{array}$ & $\begin{array}{c}\text { já } \\
\text { participei } \\
\text { X2 }\end{array}$ & Total \\
\hline Entidade beneficente & 1 & & & 4 \\
\hline Associação recreativa/esportiva & & & 1 & 2 \\
\hline Associação de defesa dos Direitos Humanos & & & & 0 \\
\hline Defesa dos Consumidores & & & & 7 \\
\hline Associação religiosa & 1 & & & 0 \\
\hline Grupos de Fé política & & & & 0 \\
\hline Associações de Moradia & 1 & & & 12 \\
\hline Partido Político & & & & 0 \\
\hline Associação de Saúde & 3 & & & 0 \\
\hline Associação ligada a educação & & & & 0 \\
\hline Associação de meio ambiente & & & & 0 \\
\hline Associação de cultura & & & & 0 \\
\hline Entidade empresarial/patronal & & & & 0 \\
\hline Entidade estudantil & & & & 3 \\
\hline Associação de auto-ajuda & & & & 37 \\
\hline Sindicato de trabalhadores & & & & \\
\hline Associação profissional & & & & \\
\hline Outros tipos de associaçães & & & & \\
\hline Total & & & & \\
\hline
\end{tabular}

FONTE: VERÍSSIMO, J. 2005.

\section{V) Indicador de Tolerância}

O indicador de tolerância não recebeu fatores de multiplicação. Para este indicador, somou-se os valores dos autoposicionamentos dos conselheiros nas escalas de tolerância (de um a 10). Deste modo que quando por Conselho, a pontuação deste indicador variou de 04 a 40 pontos para a escala de tolerância à homossexualidade e a mesma variação se observou para a escala de tolerância ao aborto. Agrupados por tempo pregresso de participação o total da somatória das escalas variou de 05 a 60 pontos para ambas categorias (homossexualidade $e$ aborto). Para o indicador final somaram-se os totais das duas escalas, de modo que a variação final observou-se entre 08 e 80 quando agregados os conselheiros 
por Conselho, e de 10 a 120 quando agrupados por tempo pregresso de participação (tabelas 05 e 5.1 do capítulo 04).

TABELA 05: TOLERÂNCIA AO ABORTO E À HOMOSSEXUALIDADE, POR CONSELHO QUE FAZ PARTE.

\begin{tabular}{|c|c|c|c|c|c|c|c|c|c|c|}
\hline \multicolumn{11}{|c|}{$\begin{array}{l}\text { Você pensa que a homossexualidade e o aborto são sempre } \\
\text { aceitáveis, nunca aceitáveis, ou você tem alguma opinião } \\
\text { intermediária? }\end{array}$} \\
\hline categ. & Conselho/ escala & 1 & 23 & \begin{tabular}{l|l}
3 & 4 \\
1
\end{tabular} & 5 & 6 & 7 & $8 !$ & 10 & Total \\
\hline \multirow{4}{*}{ Homo } & VI Prudente & & & & & & & & 4 & 40 \\
\hline & Perus & & & & & & & - & 3 & 39 \\
\hline & Cid Tiradentes & - & 1 & 1 & 1 & & & & 1 & 21 \\
\hline & Parelheiros & & & & 2 & & 1 & 1 & & 25 \\
\hline & & & & & & & & & & \\
\hline \multirow{4}{*}{ Aborto } & VI Prudente & 3 & - & 1 & & & & & & 6 \\
\hline & Perus & 2 & & & 2 & & & & & 12 \\
\hline & Cid Tiradentes & 1 & 1 & & 2 & & & & & 13 \\
\hline & Parelheiros & 3 & & & & 1 & & & & 9 \\
\hline
\end{tabular}

FONTE: VERISSIMO, J. 2005.

TABELA 5.1: TOLERÂNCIA AO ABORTO E À HOMOSSEXUALIDADE, POR PERÍODO DE INÍCIO DE PARTICIPAÇÃO.

\begin{tabular}{|c|c|c|c|c|c|c|c|c|c|c|c|}
\hline \multicolumn{12}{|c|}{$\begin{array}{l}\text { Você pensa que a homossexualidade e o aborto são sempre } \\
\text { aceitáveis, nunca aceitáveis, ou você tem alguma opinião } \\
\text { intermediária? }\end{array}$} \\
\hline categ. & Grupo/ escala & 1 & 2 & 3 & 4 & 6 & 7 & 8 & 9 & 10 & Total \\
\hline \multirow[b]{3}{*}{ Homo } & $\begin{array}{l}\text { período anterior e/ou até } \\
1980\end{array}$ & & 1 & & & | & 1 & & & 2 & 24 \\
\hline & entre 1981 e 1992 & & & & $1:$ & & & 1 & 1 & 1 & 36 \\
\hline & depois de 2001 & & & & & & & & & 5 & 50 \\
\hline \multirow{4}{*}{ Aborto } & & & & & & & & & & & \\
\hline & $\begin{array}{l}\text { período anterior e/ou até } \\
1980\end{array}$ & 3 & 1 & & & & & & & & 10 \\
\hline & entre 1981 e 1992 & 2 & & 1 & & 1 & & & & & 16 \\
\hline & depois de 2001 & 4 & & & & i & & & & & 9 \\
\hline
\end{tabular}

FONTE: VERISSIMO, J. 2005. 
VI) Indicador de Capital Social.

Uma série de variáveis foram utilizadas para se construir o indicador de capital social. Para os conselheiros que disseram conversar com os vizinhos sempre se multiplicou o número de respondentes $(\mathrm{N})$ por 04 . Já o número de conselheiros que disse conversar com seus vizinhos toda semana foi multiplicado por 03.

\section{TABELA 06: FREQUÊNCIA DE CONVERSA COM VIZINHOS, POR CONSELHO QUE FAZ PARTE.}

\begin{tabular}{|l|c|c|c|}
\hline \multicolumn{4}{|c|}{$\begin{array}{c}\text { Com que freqüência você conversa com seus } \\
\text { vizinhos? }\end{array}$} \\
\hline Conselho & todos os dias X4 & toda semana X3 & Total \\
\hline VI prudente & 2 & 2 & $\mathbf{1 4}$ \\
\hline Perus & 1 & 3 & $\mathbf{1 3}$ \\
\hline Cid Tiradentes & 3 & 1 & $\mathbf{1 5}$ \\
\hline Parelheiros & 3 & 1 & $\mathbf{1 5}$ \\
\hline
\end{tabular}

FONTE: VERISSIMO, J. 2005.

TABELA 6.1: FREQUÊNCIA DE CONVERSA COM VIZINHOS, POR PERÍODO DE INÍCIO DE PARTICIPAÇÃO.

\begin{tabular}{|l|c|c|c|}
\hline \multicolumn{5}{|c|}{ Com que freqüência você conversa com seus } \\
vizinhos? \\
\hline Período & $\begin{array}{l}\text { todos os } \\
\text { dias } x 4\end{array}$ & $\begin{array}{l}\text { toda } \\
\text { semana } \quad \text { x3 }\end{array}$ & Total \\
\hline $\begin{array}{l}\text { período anterior } \\
\text { e/ou até 1980 }\end{array}$ & 4 & 1 & $\mathbf{1 9}$ \\
\hline entre 1980 e 1992 & 5 & 1 & $\mathbf{2 3}$ \\
\hline depois de 2001 & & 5 & $\mathbf{1 5}$ \\
\hline
\end{tabular} FONTE: VERISSIMO, J. 2005.

A quantidade de conselheiros que declarou fazer sempre favores para os vizinhos foi multiplicada por 04. A que disse fazer às vezes por três, e por dois aquela que afirmou que raramente faz favores para seus vizinhos. 
TABELA 6.2: FREQUÊNCIA DE FAVORES ENTRE VIZINHOS, POR CONSELHO QUE FAZ PARTE.

\begin{tabular}{|l|c|c|c|c|c|}
\hline \multicolumn{7}{|c|}{ freqüência de favores entre vizinhos } \\
\hline Conselho & $\begin{array}{c}\text { sempre } \\
\mathrm{x} 4\end{array}$ & $\begin{array}{c}\text { às vezes } \\
\mathrm{x} 3\end{array}$ & $\begin{array}{c}\text { raramente } \\
\mathrm{x} 2\end{array}$ & nunca & Total \\
\hline VI Prudente & & 1 & 1 & 2 & $\mathbf{8}$ \\
\hline Perus & 2 & 2 & & & $\mathbf{1 4}$ \\
\hline Cid Tiradentes & 4 & & & & $\mathbf{1 6}$ \\
\hline Parelheiros & 2 & 1 & & 1 & $\mathbf{1 2}$ \\
\hline
\end{tabular}

FONTE: VERÍSSIMO, J. 2005.

\section{TABELA 6.3: FREQUÊNCIA DE FAVORES ENTRE VIZINHOS, POR PERÍODO DE INÍCIO DE PARTICIPAÇÃO.}

\begin{tabular}{|l|c|c|c|c|c|}
\hline \multicolumn{7}{|c|}{ freqüência de favores entre vizinhos } \\
\hline Período & $\begin{array}{c}\text { sempre } \\
\mathrm{x} 4\end{array}$ & $\begin{array}{c}\text { às vezes } \\
\mathrm{x} 3\end{array}$ & $\begin{array}{c}\text { raramente } \\
\mathrm{x} 2\end{array}$ & nunca & Total \\
\hline $\begin{array}{l}\text { período } \\
\text { anterior e/ou } \\
\text { até 1980 }\end{array}$ & 2 & 1 & 1 & 1 & $\mathbf{1 3}$ \\
\hline $\begin{array}{l}\text { entre 1980 e } \\
1992\end{array}$ & 4 & 2 & & & $\mathbf{2 2}$ \\
\hline $\begin{array}{l}\text { depois de } \\
2001\end{array}$ & 2 & 1 & & 2 & $\mathbf{1 1}$ \\
\hline
\end{tabular}

FONTE: VERISSIMO, J. 2005.

Já para a questão da freqüência a reuniões comunitárias para solucionar problemas do bairro ou cidade, levou-se em consideração a soma do número exato de respondentes $(\mathrm{N})$ para a construção do índice de capital social. Desta forma, o total possível para este indicador, quando agregadas as respostas do conselheiros por Conselho, foi o de oito pontos, uma vez que tratam-se de duas questões: freqüência a reuniões em órgãos públicos e/ou com vizinhos. 
TABELA 6.4: FREQUÊNCIA DE REUNIÕES COMUNITÁRIAS, POR CONSELHO QUE FAZ PARTE.

\begin{tabular}{|l|c|c||c|c||c|}
\hline \multicolumn{4}{|c|}{$\begin{array}{c}\text { Nos últimos } 12 \text { meses você se reuniu para resolver } \\
\text { problemas do seu bairro ou cidade? }\end{array}$} \\
\hline \multirow{3}{*}{ Conselho } & \multicolumn{2}{|c||c|}{$\begin{array}{c}\text { em órgãos } \\
\text { públicos }\end{array}$} & $\begin{array}{c}\text { com } \\
\text { vizinhos }\end{array}$ & \\
\cline { 2 - 5 } & Sim $\times 1$ & não & Sim X1 & não & Total \\
\hline VI Prudente & 3 & 1 & 1 & 3 & $\mathbf{4}$ \\
\hline Perus & 4 & & 4 & & $\mathbf{8}$ \\
\hline Cid Tiradentes & 4 & & 4 & & $\mathbf{8}$ \\
\hline Parelheiros & 4 & & 4 & & $\mathbf{8}$ \\
\hline
\end{tabular}

FONTE: VERÍSSIMO, J. 2005.

\section{TABELA 6.5: FREQUÊNCIA DE REUNIÕES COMUNITÁRIAS, POR PERÍODO DE INÍCIO DE PARTICIPAÇÃO.}

\begin{tabular}{|c|c|c|c|c|c|}
\hline \multicolumn{6}{|c|}{$\begin{array}{c}\text { Nos últimos } 12 \text { meses você se reuniu para resolver } \\
\text { problemas do seu bairro ou cidade? }\end{array}$} \\
\hline \multirow[t]{2}{*}{ Período } & \multicolumn{2}{|c|}{ órgãos públicos } & \multicolumn{2}{|c|}{$\begin{array}{c}\text { com } \\
\text { vizinhos }\end{array}$} & \multirow[b]{2}{*}{ Total } \\
\hline & $\operatorname{Sim} \times 1$ & não & $\operatorname{Sim} x 1$ & não & \\
\hline $\begin{array}{l}\text { período anterior } \\
\text { elou até } 1980\end{array}$ & 5 & & 4 & 1 & 9 \\
\hline $\begin{array}{l}\text { entre } 1981 \mathrm{e} \\
1992\end{array}$ & 5 & 1 & 6 & & 11 \\
\hline depois de 2001 & 5 & & 3 & 2 & 8 \\
\hline
\end{tabular}

FONTE: VERÍSSIMO, J. 2005.

A avaliação da vida social dos conselheiros foi ponderada multiplicando-se o número de conselheiros que responderam sempre desenvolver determinado tipo de atividade (como visita a casa de amigos, por exemplo), por 04. Os que responderam "as vezes" para as categorias propostas tiveram um fator de multiplicação 03 e os que disseram raramente valer-se destas atividades sociais tiveram suas respostas multiplicadas por 02 . 
TABELA 6.6: AVALIAÇÃO DA VIDA SOCIAL DOS CONSELHEIROS DE VILA PRUDENTE.

\begin{tabular}{|c|c|c|c|c|c|}
\hline \multicolumn{6}{|c|}{$\begin{array}{l}\text { Vou apresentar algumas atividades que você pode fazer durante } \\
\text { o seu tempo livre ou de lazer. Eu gostaria de saber se você }\end{array}$} \\
\hline Atividade & $\begin{array}{l}\text { Sempre } \\
\quad \times 4\end{array}$ & $\begin{array}{c}\text { Às } \\
\text { vezes } \\
\text { x3 }\end{array}$ & $\begin{array}{l}\text { Raramente } \\
\times 2\end{array}$ & Nunca & Total \\
\hline $\begin{array}{l}\text { a. Visita amigos e } \\
\text { parentes }\end{array}$ & 1 & 2 & 1 & 0 & 12 \\
\hline $\begin{array}{l}\text { b. Vai a bares ou } \\
\text { restaurantes }\end{array}$ & 1 & 2 & 1 & 0 & 12 \\
\hline c. Vai ao cinema & 0 & 0 & 3 & 1 & 6 \\
\hline $\begin{array}{l}\text { d. Vai a festas } \\
\text { (de amigos, } \\
\text { parentes, de } \\
\text { igreja, de } \\
\text { associações, etc) }\end{array}$ & 1 & 3 & 0 & 0 & 13 \\
\hline $\begin{array}{l}\text { e. Passeia em } \\
\text { praças }\end{array}$ & 1 & 2 & 0 & 1 & 10 \\
\hline $\begin{array}{l}\text { f. Passeia em } \\
\text { cachoeiras, } \\
\text { reservas naturais }\end{array}$ & 1 & 0 & 1 & 2 & 12 \\
\hline $\begin{array}{l}\text { g. Pratica } \\
\text { esportes ou fazer } \\
\text { exercícios }\end{array}$ & 1 & 0 & 0 & 3 & 4 \\
\hline $\begin{array}{l}\text { h. Vai ao estádio } \\
\text { de futebol }\end{array}$ & 1 & 0 & 1 & 2 & 6 \\
\hline i. Vai à Igreja & 2 & 1 & 1 & 0 & 13 \\
\hline Total & & & & & 88 \\
\hline
\end{tabular}

FONTE: VERÍSSIMO, J. 2005. 
TABELA 6.7: AVALIAÇÃO DA VIDA SOCIAL DOS CONSELHEIROS DE PERUS.

\begin{tabular}{|c|c|c|c|c|c|}
\hline \multicolumn{6}{|c|}{$\begin{array}{c}\text { Vou apresentar algumas atividades que você pode fazer durante o seu } \\
\text { tempo livre ou de lazer. Eu gostaria de saber se você }\end{array}$} \\
\hline Atividade & $\underset{x 4}{\text { Sempre }}$ & $\begin{array}{c}\text { Às } \\
\text { vezes } x 3\end{array}$ & $\begin{array}{c}\text { Raramente } \\
x 2\end{array}$ & Nunca & Total \\
\hline $\begin{array}{l}\text { a. Visita amigos e } \\
\text { parentes }\end{array}$ & & 3 & 1 & & 11 \\
\hline $\begin{array}{l}\text { b. Vai a bares ou } \\
\text { restaurantes }\end{array}$ & 1 & 2 & 1 & & 12 \\
\hline c. Vai ao cinema & & 1 & 1 & 2 & 5 \\
\hline $\begin{array}{l}\text { d. Vai a festas (de } \\
\text { amigos, parentes, de } \\
\text { igreja, de associações, } \\
\text { etc) }\end{array}$ & 2 & 2 & & & 14 \\
\hline e. Passeia em praças & 2 & 1 & & 1 & 11 \\
\hline $\begin{array}{l}\text { f. Passeia em } \\
\text { cachoeiras, reservas } \\
\text { naturais }\end{array}$ & & 3 & & 1 & 9 \\
\hline $\begin{array}{l}\text { g. Pratica esportes ou } \\
\text { fazer exercícios }\end{array}$ & 2 & 1 & & 1 & 11 \\
\hline $\begin{array}{l}\text { h. Vai ao estádio de } \\
\text { futebol }\end{array}$ & & & & 4 & 0 \\
\hline i. Vai à Igreja & 3 & 1 & & & 15 \\
\hline \multicolumn{5}{|l|}{ Total } & 88 \\
\hline
\end{tabular}

FONTE: VERÍSSIMO, J. 2005.

TABELA 6.8: AVALIAÇÃO DA VIDA SOCIAL DOS CONSELHEIROS DE CIDADE TIRADENTES.

\begin{tabular}{|l|c|c|c|c|c|}
\hline \multicolumn{6}{|l|}{$\begin{array}{c}\text { Vou apresentar algumas atividades que você pode fazer durante o seu } \\
\text { tempo livre ou de lazer. Eu gostaria de saber se você }\end{array}$} \\
\hline Atividade & $\begin{array}{c}\text { Sempre } \\
x 4\end{array}$ & $\begin{array}{c}\text { Às } \\
\text { vezes } x 3\end{array}$ & $\begin{array}{c}\text { Raramente } \\
x 2\end{array}$ & Nunca & Total \\
\hline $\begin{array}{l}\text { a. Visita amigos e } \\
\text { parentes }\end{array}$ & 2 & 1 & 1 & & 13 \\
\hline $\begin{array}{l}\text { b. Vai a bares ou } \\
\text { restaurantes }\end{array}$ & 1 & 1 & 1 & 1 & 9 \\
\hline c. Vai ao cinema & & 1 & 1 & 2 & 5 \\
\hline
\end{tabular}




\begin{tabular}{|c|c|c|c|c|c|}
\hline \multicolumn{6}{|c|}{ conclusão } \\
\hline Atividade & $\underset{x 4}{\text { Sempre }}$ & $\begin{array}{c}\text { Às } \\
\text { vezes } x 3\end{array}$ & $\begin{array}{c}\text { Raramente } \\
x 2\end{array}$ & Nunca & Total \\
\hline $\begin{array}{l}\text { d. Vai a festas (de } \\
\text { amigos, parentes, de } \\
\text { igreja, de associações, } \\
\text { etc) }\end{array}$ & 4 & & & & 16 \\
\hline e. Passeia em praças & 2 & 1 & & 1 & 11 \\
\hline $\begin{array}{l}\text { f. Passeia em } \\
\text { cachoeiras, reservas } \\
\text { naturais }\end{array}$ & & & 2 & 2 & 4 \\
\hline $\begin{array}{l}\text { g. Pratica esportes ou } \\
\text { fazer exercícios }\end{array}$ & 2 & 2 & & & 14 \\
\hline $\begin{array}{l}\text { h. Vai ao estádio de } \\
\text { futebol }\end{array}$ & & & & 4 & 0 \\
\hline i. Vai à Igreja & 2 & 1 & 1 & & 13 \\
\hline \multicolumn{5}{|l|}{ Total } & 85 \\
\hline
\end{tabular}

FONTE: VERÍSSIMO, J. 2005.

\section{TABELA 6.9: AVALIAÇÃO DA VIDA SOCIAL DOS CONSELHEIROS DE PARELHEIROS.}

\begin{tabular}{|c|c|c|c|c|c|}
\hline \multicolumn{6}{|c|}{$\begin{array}{c}\text { Vou apresentar algumas atividades que você pode fazer durante o seu } \\
\text { tempo livre ou de lazer. Eu gostaria de saber se você }\end{array}$} \\
\hline Atividade & 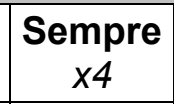 & \begin{tabular}{|c|} 
Às \\
vezes $\times 3$
\end{tabular} & $\begin{array}{c}\text { Raramente } \\
x 2\end{array}$ & Nunca & Total \\
\hline $\begin{array}{l}\text { a. Visita amigos e } \\
\text { parentes }\end{array}$ & 2 & 2 & & & 14 \\
\hline $\begin{array}{l}\text { b. Vai a bares ou } \\
\text { restaurantes }\end{array}$ & & & 1 & 3 & 2 \\
\hline c. Vai ao cinema & & & 2 & 2 & 4 \\
\hline $\begin{array}{l}\text { d. Vai a festas (de } \\
\text { amigos, parentes, de } \\
\text { igreja, de associações, } \\
\text { etc) }\end{array}$ & 3 & & 1 & & 14 \\
\hline e. Passeia em praças & & & 1 & 3 & 2 \\
\hline $\begin{array}{l}\text { f. Passeia em } \\
\text { cachoeiras, reservas } \\
\text { naturais }\end{array}$ & & 2 & & 2 & 6 \\
\hline $\begin{array}{l}\text { g. Pratica esportes ou } \\
\text { fazer exercícios }\end{array}$ & 1 & 1 & & 2 & 7 \\
\hline $\begin{array}{l}\text { h. Vai ao estádio de } \\
\text { futebol }\end{array}$ & & & 1 & 3 & 2 \\
\hline
\end{tabular}




\begin{tabular}{|l|c|c|c|c|c|}
\hline \multicolumn{9}{|c|}{ Atividade } & $\begin{array}{c}\text { Sempre } \\
x 4\end{array}$ & $\begin{array}{c}\text { Às } \\
\text { vezes } x 3\end{array}$ & $\begin{array}{c}\text { Raramente } \\
x 2\end{array}$ & Nunca & Total \\
\hline i. Vai à lgreja & 3 & 1 & & & 15 \\
\hline Total & \multicolumn{3}{|l}{} & 66 \\
\hline
\end{tabular}

FONTE: VERÍSSIMO, J. 2005.

TABELA 6.10: AVALIAÇÃO DA VIDA SOCIAL DOS CONSELHEIROS QUE INICIARAM SUA PARTICIPAÇÃO NO PERÍODO ANTERIOR E/OU ATÉ 1980.

\begin{tabular}{|c|c|c|c|c|c|}
\hline \multicolumn{6}{|c|}{$\begin{array}{c}\text { Vou apresentar algumas atividades que você pode fazer durante o seu } \\
\text { tempo livre ou de lazer. Eu gostaria de saber se você }\end{array}$} \\
\hline Atividade & $\underset{X 4}{\text { Sempre }}$ & $\begin{array}{c}\text { Às } \\
\text { vezes } \\
X 3\end{array}$ & $\begin{array}{c}\text { Raramente } \\
X 2\end{array}$ & Nunca & Total \\
\hline $\begin{array}{l}\text { a. Visita amigos e } \\
\text { parentes }\end{array}$ & 2 & 2 & 1 & & 16 \\
\hline $\begin{array}{l}\text { b. Vai a bares ou } \\
\text { restaurantes }\end{array}$ & & & 3 & 2 & 6 \\
\hline c. Vai ao cinema & & & 1 & 4 & 2 \\
\hline $\begin{array}{l}\text { d. Vai a festas (de } \\
\text { amigos, parentes, de } \\
\text { igreja, de associações, } \\
\text { etc) }\end{array}$ & 4 & & 1 & & 18 \\
\hline e. Passeia em praças & 1 & & 1 & 3 & 6 \\
\hline $\begin{array}{l}\text { f. Passeia em } \\
\text { cachoeiras, reservas } \\
\text { naturais }\end{array}$ & 1 & 1 & 1 & 2 & 9 \\
\hline $\begin{array}{l}\text { g. Pratica esportes ou } \\
\text { fazer exercícios }\end{array}$ & 1 & 2 & & 2 & 7 \\
\hline $\begin{array}{l}\text { h. Vai ao estádio de } \\
\text { futebol }\end{array}$ & 1 & & & 4 & 4 \\
\hline i. Vai à lgreja & 5 & & & & 20 \\
\hline \multicolumn{5}{|l|}{ Total } & 88 \\
\hline
\end{tabular}

FONTE: VERÍSSIMO, J. 2005. 
TABELA 6.11: AVALIAÇÃO DA VIDA SOCIAL DOS CONSELHEIROS QUE INICIARAM SUA PARTIÇIPAÇÃO ENTRE 1981 E 1992.

\begin{tabular}{|c|c|c|c|c|c|}
\hline \multicolumn{6}{|c|}{$\begin{array}{l}\text { Vou apresentar algumas atividades que você pode fazer durante o } \\
\text { seu tempo livre ou de lazer. Eu gostaria de saber se você }\end{array}$} \\
\hline Atividade & $\begin{array}{l}\text { Sempre } \\
\times 4\end{array}$ & $\begin{array}{c}\text { Às } \\
\text { vezes } \\
\text { X3 }\end{array}$ & $\underset{X 2}{\text { Raramente }}$ & Nunca & Total \\
\hline $\begin{array}{l}\text { a. Visita amigos e } \\
\text { parentes }\end{array}$ & & 3 & 3 & & 15 \\
\hline $\begin{array}{l}\text { b. Vai a bares ou } \\
\text { restaurantes }\end{array}$ & 1 & 1 & 2 & 2 & 11 \\
\hline c. Vai ao cinema & & 2 & 3 & 1 & 12 \\
\hline $\begin{array}{l}\text { d. Vai a festas (de } \\
\text { amigos, parentes, } \\
\text { de igreja, de } \\
\text { associações, etc) }\end{array}$ & 4 & 2 & & & 22 \\
\hline $\begin{array}{l}\text { e. Passeia em } \\
\text { praças }\end{array}$ & & 1 & 4 & 1 & 11 \\
\hline $\begin{array}{l}\text { f. Passeia em } \\
\text { cachoeiras, } \\
\text { reservas naturais }\end{array}$ & & 3 & 2 & 1 & 15 \\
\hline $\begin{array}{l}\text { g. Pratica } \\
\text { esportes ou fazer } \\
\text { exercícios }\end{array}$ & 2 & & 2 & 2 & 12 \\
\hline $\begin{array}{l}\text { h. Vai ao estádio } \\
\text { de futebol }\end{array}$ & & & 2 & 4 & 4 \\
\hline i. Vai à Igreja & 4 & 1 & 1 & & 21 \\
\hline Total & & & & & 123 \\
\hline
\end{tabular}

FONTE: VERÍSSIMO, J. 2005. 
TABELA 6.12: AVALIAÇÃO DA VIDA SOCIAL DOS CONSELHEIROS QUE INICIARAM SUA PARTICIPAÇÃO DEPOIS DE 2001.

\begin{tabular}{|c|c|c|c|c|c|}
\hline \multicolumn{6}{|c|}{$\begin{array}{c}\text { Vou apresentar algumas atividades que você pode fazer durante o } \\
\text { seu tempo livre ou de lazer. Eu gostaria de saber se você }\end{array}$} \\
\hline Atividade & $\begin{array}{l}\text { Sempre } \\
\quad X 4\end{array}$ & $\begin{array}{l}\text { Às vezes } \\
\quad X 3\end{array}$ & $\begin{array}{l}\text { Raramente } \\
\quad \times 2\end{array}$ & Nunca & Total \\
\hline $\begin{array}{l}\text { a. Visita amigos e } \\
\text { parentes }\end{array}$ & & 2 & 3 & & 15 \\
\hline $\begin{array}{l}\text { b. Vai a bares ou } \\
\text { restaurantes }\end{array}$ & 1 & 3 & & 1 & 13 \\
\hline c. Vai ao cinema & & & 3 & 2 & 6 \\
\hline $\begin{array}{l}\text { d. Vai a festas } \\
\text { (de amigos, } \\
\text { parentes, de } \\
\text { igreja, de } \\
\text { associações, etc) }\end{array}$ & 2 & 3 & & & 14 \\
\hline $\begin{array}{l}\text { e. Passeia em } \\
\text { praças }\end{array}$ & 2 & 1 & & 2 & 11 \\
\hline $\begin{array}{l}\text { f. Passeia em } \\
\text { cachoeiras, } \\
\text { reservas naturais }\end{array}$ & & 1 & & 4 & 3 \\
\hline $\begin{array}{l}\text { g. Pratica } \\
\text { esportes ou fazer } \\
\text { exercícios }\end{array}$ & 3 & & & 2 & 12 \\
\hline $\begin{array}{l}\text { h. Vai ao estádio } \\
\text { de futebol }\end{array}$ & & & & 5 & 0 \\
\hline i. Vai à Igreja & 1 & 2 & 1 & 1 & 12 \\
\hline \multicolumn{5}{|l|}{ Total } & 86 \\
\hline
\end{tabular}

FONTE: VERÍSSIMO, J. 2005.

VII) Indicador de Confiança Generalizada, na Polícia e no sistema médico.

Para se construir o indicador de confiança generalizada atribuiu-se o fator de multiplicação três para o número de conselheiros que disse concordar totalmente com as afirmações de que as pessoas do bairro são confiáveis e prestativas. Os que concordaram em parte tiveram suas respostas ponderadas por dois, e os que afirmaram discordar em parte por 01. 
TABELA 7: CONFIANÇA NOS MORADORES DO BAIRRO, POR CONSELHO QUE FAZ PARTE

\begin{tabular}{|l|c|c|c|c|}
\hline \multicolumn{5}{|c|}{ As pessoas do bairro são confiáveis? } \\
\hline Conselho & $\begin{array}{c}\text { concorda } \\
\text { totalmente } \\
\text { X3 }\end{array}$ & $\begin{array}{c}\text { concorda } \\
\text { em parte } \\
\text { X2 }\end{array}$ & $\begin{array}{c}\text { discorda } \\
\text { em parte } \\
\text { X1 }\end{array}$ & Total \\
\hline VI Prudente & 1 & 3 & & $\mathbf{9}$ \\
\hline Perus & & 2 & 2 & $\mathbf{6}$ \\
\hline Cid Tiradentes & & 3 & 1 & $\mathbf{7}$ \\
\hline Parelheiros & & 4 & & $\mathbf{8}$ \\
\hline
\end{tabular}

FONTE: VERISSIMO, J. 2005.

TABELA 7.1: CONFIANÇA NOS MORADORES DO BAIRRO, POR PERÍODO DE INÍCIO DE PARTICIPAÇÃO.

\begin{tabular}{|l|c|c|c|c|}
\hline \multicolumn{5}{|c|}{ As pessoas do bairro são confiáveis? } \\
\hline Período & $\begin{array}{c}\text { concorda } \\
\text { totalmente } \\
\text { X3 }\end{array}$ & $\begin{array}{c}\text { concorda } \\
\text { em parte } \\
\text { X2 }\end{array}$ & $\begin{array}{c}\text { discorda } \\
\text { em parte } \\
\text { X1 }\end{array}$ & Total \\
\hline $\begin{array}{l}\text { período anterior } \\
\text { e/ou até 1980 }\end{array}$ & & 5 & & 10 \\
\hline $\begin{array}{l}\text { entre 1981 e } \\
1992\end{array}$ & 1 & 3 & 2 & 11 \\
\hline depois de 2001 & & 4 & 1 & $\mathbf{9}$ \\
\hline
\end{tabular}

FONTE: VERISSIMO, J. 2005.

TABELA 7.2: AVALIAÇÃO DA SOLICITUDE DOS VIZINHOS, POR CONSELHO QUE FAZ PARTE.

\begin{tabular}{|l|c|c|c|c|c|}
\hline \multicolumn{7}{|c|}{ Seus vizinhos são pessoas prestativas? } \\
\hline Conselho & $\begin{array}{c}\text { concorda } \\
\text { totalmente } \\
\text { X3 }\end{array}$ & $\begin{array}{c}\text { concorda em } \\
\text { parte X2 }\end{array}$ & $\begin{array}{c}\text { discorda } \\
\text { em parte } \\
\text { X1 }\end{array}$ & $\begin{array}{c}\text { discorda } \\
\text { totalmente }\end{array}$ & Total \\
\hline VI Prudente & 1 & 3 & & & $\mathbf{9}$ \\
\hline Perus & 1 & & 2 & 1 & $\mathbf{5}$ \\
\hline $\begin{array}{l}\text { Cid } \\
\text { Tiradentes }\end{array}$ & & 3 & 1 & & $\mathbf{7}$ \\
\hline Parelheiros & 1 & 2 & & 1 & $\mathbf{7}$ \\
\hline
\end{tabular}

FONTE: VERISSIMO, J. 2005. 
TABELA 7.2.1: AVALIAÇÃO DA SOLICITUDE DOS VIZINHOS, POR PERÍODO DE INÍCIO DE PARTICIPAÇÃO.

\begin{tabular}{|l|c|c|c|c|c|}
\hline \multicolumn{5}{|c|}{ Seus vizinhos são pessoas prestativas? } \\
\hline Período & $\begin{array}{c}\text { concorda } \\
\text { totalmente } \\
\text { X3 }\end{array}$ & $\begin{array}{c}\text { concorda } \\
\text { em parte } \\
\text { X2 }\end{array}$ & $\begin{array}{c}\text { discorda em } \\
\text { parte } \\
\text { X1 }\end{array}$ & $\begin{array}{c}\text { discorda } \\
\text { totalmente }\end{array}$ & Total \\
\hline $\begin{array}{l}\text { período anterior } \\
\text { elou até 1980 }\end{array}$ & 2 & 2 & & 1 & 10 \\
\hline $\begin{array}{l}\text { entre 1981 e } \\
1992\end{array}$ & 1 & 3 & 2 & & 11 \\
\hline depois de 2001 & & 3 & 1 & 1 & 7 \\
\hline
\end{tabular}

FONTE: VERISSIMO, J. 2005.

Também para medir confiança generalizada, perguntou-se aos conselheiros se estes achavam que se pode confiar na maioria das pessoas ou que ter cuidado nunca é demais. Para o número de respondentes $(\mathrm{N})$ que disse se poder confiar na maioria das pessoas atribuiu-se o fator de ponderação 02 .

TABELA 7.3: AVALIAÇÃO DE CONFIANÇA GENERALIZADA, POR CONSELHO QUE FAZ PARTE.

\begin{tabular}{|l|c|c|c|}
\hline \multicolumn{3}{|c|}{$\begin{array}{c}\text { De maneira geral, você diria que podemos confiar na maioria } \\
\text { das pessoas, ou você acha que cuidado nunca é demais? }\end{array}$} \\
\hline Conselho & $\begin{array}{c}\text { podemos confiar na } \\
\text { maioria das pessoas } \\
\text { X2 }\end{array}$ & $\begin{array}{c}\text { cuidado nunca e } \\
\text { demais }\end{array}$ & Total \\
\hline VI Prudente & 1 & 3 & $\mathbf{2}$ \\
\hline Perus & 1 & 3 & $\mathbf{2}$ \\
\hline $\begin{array}{l}\text { Cid } \\
\text { Tiradentes }\end{array}$ & & 4 & $\mathbf{0}$ \\
\hline Parelheiros & 1 & 3 & $\mathbf{2}$ \\
\hline
\end{tabular}

FONTE: VERÍSSIMO, J. 2005. 
TABELA 7.3.1: AVALIAÇÃO DE CONFIANÇA GENERALIZADA, POR PERÍODO DE INÍCIO DE PARTICIPAÇÃO.

\begin{tabular}{|l|c|c|c|}
\hline \multicolumn{3}{|c|}{$\begin{array}{c}\text { De maneira geral, você diria que podemos } \\
\text { confiar na maioria das pessoas, ou você acha } \\
\text { que cuidado nunca é demais? }\end{array}$} \\
\hline $\begin{array}{l}\text { Período } \\
\begin{array}{c}\text { podemos confiar } \\
\text { na maioria das } \\
\text { pessoas } \\
\text { X2 }\end{array}\end{array}$ & $\begin{array}{c}\text { cuidado } \\
\text { nunca e } \\
\text { demais }\end{array}$ & Total \\
\hline $\begin{array}{l}\text { período } \\
\text { anterior } \\
\text { e/ou até } \\
1980\end{array}$ & 3 & & \\
\hline $\begin{array}{l}\text { entre } \\
1981 \text { e } \\
1992\end{array}$ & & 2 & $\mathbf{6}$ \\
\hline $\begin{array}{l}\text { depois de } \\
2001\end{array}$ & & 6 & 0 \\
\hline
\end{tabular}

FONTE: VERÍSSIMO, J. 2005.

Quando perguntados sobre sua confiança na atuação da polícia e do sistema médico para resolverem problemas de segurança e saúde, respectivamente, os conselheiros que responderam que confiam na polícia, nos médicos tiveram a quantidade de respondentes multiplicadas por 02.

TABELA 7.4: CONFIANÇA NA ATUAÇÃO DA PM, POR CONSELHO QUE FAZ PARTE.

\begin{tabular}{|l|c|c|c|c|}
\hline \multicolumn{5}{|c|}{ Pensando na atuação da Polícia Militar (PM) em sua vizinhança, você } \\
\hline Conselho & confia X2 & confia pouco X1 & não confia & Total \\
\hline Vl. Prudente & & 3 & 1 & $\mathbf{3}$ \\
\hline Perus & 1 & 2 & 1 & $\mathbf{4}$ \\
\hline Cid. Tiradentes & 1 & 1 & 2 & $\mathbf{3}$ \\
\hline Parelheiros & 2 & 2 & & $\mathbf{6}$ \\
\hline
\end{tabular}

FONTE: VERISSIMO, J. 2005 
TABELA 7.4.1: CONFIANÇA NA ATUAÇÃO DA PM, POR PERÍODO DE INÍCIO DE PARTICIPAÇÃO.

\begin{tabular}{|l|c|c|c|c|}
\hline \multicolumn{5}{|c|}{ Pensando na atuação da Polícia Militar (PM) em sua vizinhança, você } \\
\hline Período & confia X2 & confia pouco X1 & não confia & Total \\
\hline $\begin{array}{l}\text { período anterior e/ou } \\
\text { até 1980 }\end{array}$ & 2 & 2 & 1 & $\mathbf{6}$ \\
\hline entre 1981 e 1992 & 1 & 3 & 2 & $\mathbf{5}$ \\
\hline depois de 2001 & 1 & 3 & 1 & $\mathbf{5}$ \\
\hline FONTE: VERÍSSIMO, J. 2005
\end{tabular}

Questionados sobre a eficiência da PM e do sistema de saúde para resolverem problemas em suas áreas de competência, o número de conselheiros que julgou estas instituições eficientes foi multiplicado por 02, já a quantidade dos que avaliaram estas instituições públicas como pouco eficientes foi ponderada por 01.

TABELA 7.5: AVALIAÇÃO DA EFICIÊNCIA DA PM, POR CONSELHO QUE FAZ PARTE.

\begin{tabular}{|l|c|c|c|c|}
\hline \multicolumn{5}{|c|}{ Pensando na resolução de problemas de violência em sua vizinhança, você } \\
diria que a PM é ...
\end{tabular}

FONTE: VERISSIMO, J. 2005

TABELA 7.5.1: AVALIAÇÃO DA EFICÊNCIA DA PM, POR PERÍODO DE INÍCIO DE PARTICIPAÇÃO.

\begin{tabular}{|l|c|c|c|c|}
\hline \multicolumn{5}{|c|}{ Pensando na resolução de problemas de violência em sua vizinhança, você } \\
diria que a PM é ...
\end{tabular}

FONTE: VERISSIMO, J. 2005 
TABELA 7.6: CONFIANÇA NO ATENDIMENTO À SAÚDE, POR CONSELHO QUE FAZ PARTE.

\begin{tabular}{|l|c|c|c|c|}
\hline \multicolumn{5}{|c|}{ Como você se sente ao precisar de atendimento à saúde na sua } \\
vizinhança?
\end{tabular}

FONTE: VERISSSIMO, J. 2005.

TABELA 7.6.1: CONFIANÇA NO ATENDIMENTO À SAÚDE, POR PERÍODO DE INÍCIO DE PARTICIPAÇÃO.

\begin{tabular}{|l|c|c|c|c|}
\hline \multicolumn{5}{|c|}{ Como você se sente ao precisar de atendimento à saúde na sua } \\
vizinhança? \\
\hline Período & $\begin{array}{c}\text { seguro } \\
\text { X2 }\end{array}$ & $\begin{array}{c}\text { inseguro } \\
\text { X1 }\end{array}$ & muito inseguro & Total \\
\hline $\begin{array}{l}\text { período anterior } \\
\text { elou até 1980 }\end{array}$ & 2 & 3 & & \\
\hline entre 1981 e 1992 & 1 & 5 & & 7 \\
\hline depois de 2001 & & 2 & 3 & 2 \\
\hline
\end{tabular}

FONTE: VERISSIMO, J. 2005

TABELA 7.7: CONFIANÇA NOS MÉDICOS, POR CONSELHO QUE FAZ PARTE.

\begin{tabular}{|l|l|c|c|c|}
\hline \multicolumn{5}{|c|}{$\begin{array}{l}\text { Pensando na atuação dos médicos dos postos de saúde e hospitais em } \\
\text { sua vizinhança, você }\end{array}$} \\
\hline Conselho & confia muito X3 & confia X2 & confia pouco X1 & Total \\
\hline Vl. Prudente & 1 & 2 & 1 & $\mathbf{8}$ \\
\hline Perus & & 2 & 2 & $\mathbf{6}$ \\
\hline Cid. Tiradentes & & 2 & 2 & $\mathbf{6}$ \\
\hline Parelheiros & & 3 & 1 & $\mathbf{7}$ \\
\hline
\end{tabular}

FONTE: VERISSSIMO, J. 2005 
TABELA 7.7.1: CONFIANÇA NOS MÉDICOS, POR PERÍODO DE INÍCIO DE PARTICIPAÇÃO.

\begin{tabular}{|l|c|c|c|c|}
\hline \multicolumn{5}{|c|}{ Pensando na atuação dos médicos dos postos de saúde e hospitais em } \\
sua vizinhança, você
\end{tabular}

FONTE: VERÍSSIMO, J. 2005

TABELA 7.8: AVALIAÇÃO DA EFICIÊNCIA DO SISTEMA DE SAÚDE, POR CONSELHO QUE FAZ PARTE.

\begin{tabular}{|l|c|c|c|}
\hline \multicolumn{4}{|c|}{$\begin{array}{c}\text { Pensando na resolução de seus problemas de saúde em sua } \\
\text { vizinhança, você diria que as unidades de saúde são ... }\end{array}$} \\
\hline Conselho & eficiente X2 & pouco eficiente X1 & Total \\
\hline Vl. Prudente & 2 & 2 & $\mathbf{6}$ \\
\hline Perus & 1 & 3 & $\mathbf{5}$ \\
\hline Cid. Tiradentes & 1 & 3 & $\mathbf{5}$ \\
\hline Parelheiros & 2 & 2 & $\mathbf{6}$ \\
\hline
\end{tabular}

FONTE: VERISSIMO, J. 2005

TABELA 7.8.1: AVALIAÇÃO DA EFICIÊNCIA DO SISTEMA DE SAÚDE, POR PERÍODO DE INÍCIO DE PARTICIPAÇÃO.

\begin{tabular}{|l|c|c|c|}
\hline \multicolumn{4}{|c|}{$\begin{array}{c}\text { Pensando na resolução de seus problemas de saúde em sua } \\
\text { vizinhança, você diria que as unidades de saúde são ... }\end{array}$} \\
\hline Período & eficiente X2 & pouco eficiente X1 & Total \\
\hline $\begin{array}{l}\text { período anterior } \\
\text { e/ou até 1980 }\end{array}$ & 3 & 2 & $\mathbf{8}$ \\
\hline entre 1981 e 1992 & 1 & 5 & $\mathbf{7}$ \\
\hline depois de 2001 & 2 & 3 & $\mathbf{7}$ \\
\hline
\end{tabular}

FONTE: VERÍSSIMO, J. 2005 
VIII) Indicador de avaliação dos CGS, e das percepções dos conselheiros acerca das diretrizes institucionais do SUS (publicidade, universalidade, integralidade e controle social).

Diversos outros indicadores foram utilizados para avaliar as percepções dos conselheiros acerca da implementação dos Conselhos, bem como para medir suas percepções acerca do bem público.

O número de conselheiros que demonstrou maior otimismo com a implantação dos CGS em relação à geração de acesso da população às decisões na área da saúde (categoria "aumentou" nas tabelas 08 a 8.3), foi multiplicado por 03.

TABELA 08: OPORTUNIDADES GERADAS PELA IMPLEMENTAÇÃO DOS CONSELHOS, SEGUNDO CONSELHEIROS DE VILA PRUDENTE.

\begin{tabular}{|l|c|c|c|c|}
\hline \multicolumn{4}{|c|}{$\begin{array}{c}\text { Na sua opinião, com os Conselhos de Saúde ... na } \\
\text { sua região aumentam, diminuem ou continuam } \\
\text { iguais? }\end{array}$} \\
\hline Conselho & \multicolumn{3}{|c|}{ Vila Prudente } \\
\hline Oportunidades & $\begin{array}{c}\text { decidir } \\
\text { sobre } \\
\text { as } \\
\text { obras } \\
\text { de } \\
\text { saúde }\end{array}$ & $\begin{array}{c}\text { prestação } \\
\text { de contas } \\
\text { das Sub }\end{array}$ & $\begin{array}{c}\text { atenção } \\
\text { às } \\
\text { demandas } \\
\text { da } \\
\text { população }\end{array}$ & Total \\
\hline Aumentou X3 & 4 & 3 & 2 & 27 \\
\hline $\begin{array}{l}\text { Continua igual } \\
\text { X2 }\end{array}$ & 1 & 2 & 6 \\
\hline Total & & & 33 \\
\hline
\end{tabular}

FONTE: VERÍSSIMO, J. 2005 
TABELA 8.1: OPORTUNIDADES GERADAS PELA IMPLEMENTAÇÃO DOS CONSELHOS, SEGUNDO CONSELHEIROS DE PERUS.

\begin{tabular}{|l|c|c|c|c|}
\hline \multicolumn{4}{|c|}{$\begin{array}{c}\text { Na sua opinião, com os Conselhos de Saúde ... na } \\
\text { sua região aumentam, diminuem ou continuam } \\
\text { iguais? }\end{array}$} \\
\hline Conselho & \multicolumn{4}{|c|}{ Perus } \\
\hline Oportunidades & $\begin{array}{c}\text { decidir } \\
\text { sobre } \\
\text { as } \\
\text { obras } \\
\text { de } \\
\text { saúde }\end{array}$ & $\begin{array}{c}\text { prestaçãa } \\
\text { o de } \\
\text { contas } \\
\text { das Sub }\end{array}$ & $\begin{array}{c}\text { atenção } \\
\text { às } \\
\text { demanda } \\
\text { s da } \\
\text { população }\end{array}$ & Total \\
\hline Aumentou X3 & & & & 0 \\
\hline $\begin{array}{l}\text { continua igual } \\
\text { X2 }\end{array}$ & 2 & 1 & 4 & 14 \\
\hline Total & & & 14 \\
\hline
\end{tabular}

FONTE: VERISSIMO, J. 2005

TABELA 8.1.1: OPORTUNIDADES GERADAS PELA IMPLEMENTAÇÃO DOS CONSELHOS, SEGUNDO CONSELHEIROS DE CIDADE TIRADENTES.

\begin{tabular}{|l|c|c|c|c|}
\hline \multicolumn{3}{|c|}{$\begin{array}{c}\text { Na sua opinião, com os Conselhos de Saúde ... na } \\
\text { sua região aumentam, diminuem ou continuam } \\
\text { iguais? }\end{array}$} \\
\hline Conselho & \multicolumn{3}{|c|}{ Cidade Tiradentes } \\
\hline Oportunidades & $\begin{array}{c}\text { decidir } \\
\text { sobre } \\
\text { as } \\
\text { obras } \\
\text { de } \\
\text { saúde }\end{array}$ & $\begin{array}{c}\text { prestação } \\
\text { de contas } \\
\text { das Sub }\end{array}$ & $\begin{array}{c}\text { atenção } \\
\text { às } \\
\text { demandas } \\
\text { da } \\
\text { população }\end{array}$ & Total \\
\hline aumentou X3 & 3 & 4 & 2 & 27 \\
\hline $\begin{array}{l}\text { Continua igual } \\
\text { X2 }\end{array}$ & & 1 & 2 \\
\hline Total & & & & 29 \\
\hline
\end{tabular}

FONTE: VERÍSSIMO, J. 2005 
TABELA 8.1.2: OPORTUNIDADES GERADAS PELA IMPLEMENTAÇÃO DOS CONSELHOS, SEGUNDO CONSEHEIROS DE PARELHEIROS.

\begin{tabular}{|l|c|c|c|c|}
\hline \multicolumn{4}{|c|}{$\begin{array}{c}\text { Na sua opinião, com os Conselhos de Saúde ... na } \\
\text { sua região aumentam, diminuem ou continuam } \\
\text { iguais? }\end{array}$} \\
\hline Conselho & \multicolumn{3}{|c|}{ Parelheiros } \\
\hline Oportunidades & $\begin{array}{c}\text { decidir } \\
\text { sobre } \\
\text { as } \\
\text { obras } \\
\text { de } \\
\text { saúde }\end{array}$ & $\begin{array}{c}\text { prestação } \\
\text { de contas } \\
\text { das Sub }\end{array}$ & $\begin{array}{c}\text { atenção } \\
\text { às } \\
\text { demandas } \\
\text { da } \\
\text { população }\end{array}$ & Total \\
\hline aumentou X3 & 3 & 2 & 2 & 21 \\
\hline $\begin{array}{l}\text { Continua igual } \\
\text { X2 }\end{array}$ & 1 & 1 & 4 \\
\hline Total & & & 25 \\
\hline FONTE: VERISSIMO, J. 2005
\end{tabular}

\section{TABELA 8.2: OPORTUNIDADES GERADAS PELA IMPLEMENTAÇÃO DOS CONSELHOS, POR PERÍODO DE INÍCIO DE PARTICIPAÇÃO.}

\begin{tabular}{|c|c|c|c|c|c|c|c|c|c|}
\hline \multicolumn{10}{|c|}{$\begin{array}{c}\text { Na sua opinião, com os Conselhos de Saúde ... na sua região aumentam, diminuem } \\
\text { ou continuam iguais? }\end{array}$} \\
\hline \multirow{2}{*}{ Período } & \multicolumn{3}{|c|}{$\begin{array}{c}\text { período anterior e/ou até } \\
1980\end{array}$} & \multicolumn{3}{|c|}{ entre 1981 e 1992} & \multicolumn{3}{|c|}{ depois de 2001} \\
\hline & \begin{tabular}{c|} 
aumentou \\
$\times 3$
\end{tabular} & diminuiu & $\begin{array}{l}\text { continua } \\
\text { igual } X 2\end{array}$ & $\begin{array}{c}\text { aumentou } \\
\times 3\end{array}$ & diminuiu & $\begin{array}{l}\text { continua } \\
\text { igual } X 2\end{array}$ & $\begin{array}{c}\text { aumentou } \\
\text { X3 }\end{array}$ & diminuiu & $\begin{array}{l}\text { continua } \\
\text { igual } \times 2\end{array}$ \\
\hline $\begin{array}{l}\text { decidir } \\
\text { sobre as } \\
\text { obras de } \\
\text { saúde }\end{array}$ & 3 & 2 & 0 & 5 & & & 2 & 2 & 1 \\
\hline $\begin{array}{l}\text { prestação } \\
\text { de contas } \\
\text { das Sub }\end{array}$ & 3 & 1 & 1 & 4 & 1 & 1 & 2 & 2 & 1 \\
\hline $\begin{array}{c}\text { atenção às } \\
\text { demandas } \\
\text { da } \\
\text { população }\end{array}$ & 3 & 1 & 1 & 3 & & 3 & 0 & 1 & 4 \\
\hline $\begin{array}{l}\text { poder dos } \\
\text { Vereadores }\end{array}$ & 1 & 1 & 2 & 2 & 2 & 2 & 2 & & 3 \\
\hline Total & \multicolumn{3}{|c|}{36} & \multicolumn{3}{|c|}{47} & \multicolumn{3}{|c|}{29} \\
\hline
\end{tabular}

FONTE: VERÍSSIMO, J. 2005 
Tratando-se da organização dos Conselhos, o número de entrevistados que respondeu que a organização dos Conselhos tem sido muito democrática foi multiplicado por 03. O que disse democrática por 02, e pouco democrática por 01.

\section{TABELA 8.3: GRAU DE DEMOCRATIZAÇÃO NA ORGANIZAÇÃO DOS CONSELHOS, POR CONSELHO QUE FAZ PARTE.}

\begin{tabular}{|l|c|c|c|c|}
\hline \multicolumn{5}{|c|}{ Na sua opinião, a organização do CGS tem sido: } \\
\hline Conselho & $\begin{array}{c}\text { muito } \\
\text { democrática } \\
X 3\end{array}$ & $\begin{array}{c}\text { democrática } \\
X 2\end{array}$ & $\begin{array}{c}\text { pouco } \\
\text { democrática } \\
X 1\end{array}$ & Total \\
\hline VI Prudente & 1 & 2 & 1 & $\mathbf{8}$ \\
\hline Perus & & 2 & 2 & $\mathbf{6}$ \\
\hline $\begin{array}{l}\text { Cid } \\
\text { Tiradentes }\end{array}$ & & 3 & 1 & 7 \\
\hline Parelheiros & 1 & 1 & 2 & $\mathbf{7}$ \\
\hline
\end{tabular}

FONTE: VERISSIMO, J. 2005

\section{TABELA 8.3.1: GRAU DE DEMOCRATIZAÇÃO NA ORGANIZAÇÃO DOS CONSELHOS, POR PERÍODO DE INÍCIO DE PARTICIPAÇÃO.}

\begin{tabular}{|l|c|c|c|c|}
\hline \multicolumn{5}{|c|}{ Avaliação da organização do CGS } \\
\hline Período & $\begin{array}{c}\text { muito } \\
\text { democrática } \\
\text { X3 }\end{array}$ & $\begin{array}{c}\text { democrática } \\
\text { X2 }\end{array}$ & $\begin{array}{c}\text { pouco } \\
\text { democrática } \\
\text { X1 }\end{array}$ & Total \\
\hline $\begin{array}{l}\text { período anterior } \\
\text { e/ou até 1980 }\end{array}$ & 1 & 3 & 1 & 10 \\
\hline $\begin{array}{l}\text { entre 1981 e } \\
1992\end{array}$ & 1 & 3 & 3 & $\mathbf{9}$ \\
\hline depois de 2001 & 1 & 2 & 2 & $\mathbf{9}$ \\
\hline
\end{tabular}

FONTE: VERÍSSIMO, J. 2005

O critério para ponderação das tabelas que se seguem é a mesma utilizada para o indicador de tolerância. Dada uma escala que varia de zero a 10 (demonstrando concordância ou não com a assertiva a eles apresentada), somaram-se os números nos quais os conselheiros se autoposicionaram. Assim, se vê no primeiro item de Vila Prudente, por exemplo, que um conselheiro declarou discordância 
veemente em relação a atitude da Prefeitura (autoposicionamento 01 na escala), dois assumiram discordância intermediária (pontos quatro e cinco da escala) e um demonstrou concordância absoluta: 10. Desta maneira, a pontuação dos conselheiros deste Conselho, para este tópico, foi de 20 pontos.

TABELA 09: AVALIAÇÃO CÍVICO-REPUBLICANA (CASO E.1), POR CONSELHO QUE FAZ PARTE.

\begin{tabular}{|c|c|c|c|c|c|c|c|c|c|c|c|c|c|c|c|c|c|c|c|c|c|}
\hline \multicolumn{22}{|c|}{ Tratamento em outra cidade - D.1 ${ }^{*}$} \\
\hline Conselho & \multicolumn{5}{|c|}{ VI Prudente } & \multicolumn{5}{|c|}{ Perus } & \multicolumn{6}{|c|}{ Cid Tiradentes } & \multicolumn{5}{|c|}{ Parelheiros } \\
\hline Avaliação & 1 & 4 & 5 & 10 & Total & 1 & 5 & & 10 & Total & 1 & 5 & 6 & 71 & 0 & Total & 13 & $\begin{array}{lll}3 & 6 \\
\end{array}$ & 8 & 10 & Total \\
\hline $\begin{array}{l}1 \text { - Prefeitura agiu } \\
\text { corretamente }\end{array}$ & 1 & 1 & 1 & 1 & 20 & 3 & & & 1 & 13 & 3 & & & 1 & & 10 & 2 & & 1 & 1 & 20 \\
\hline $\begin{array}{l}2 \text { - Prefeitura agiu } \\
\text { de maneira errada }\end{array}$ & 1 & 1 & & 2 & 25 & & 2 & & 2 & 30 & & 1 & & 3 & 3 & 35 & 2 & 1 & & 1 & 18 \\
\hline $\begin{array}{l}3 \text { - hospital da } \\
\text { cidade não deveria } \\
\text { receber }\end{array}$ & 2 & 1 & 1 & & 11 & 2 & 1 & & 1 & 17 & 1 & 1 & & 2 & 2 & 26 & 2 & 1 & & 1 & 12 \\
\hline $\begin{array}{l}4 \text {-moradores } \\
\text { cidadezinha } \\
\text { deveriam reivindicar } \\
\text { hospital }\end{array}$ & & & 1 & 3 & 35 & & & 1 & 3 & 39 & & 1 & & 3 & 3 & 35 & 1 & & 1 & 2 & 29 \\
\hline $\begin{array}{l}5 \text { - moradores da } \\
\text { capital deveriam se } \\
\text { unir para impedir } \\
\text { vinda de pacientes } \\
\text { de outra cidade }\end{array}$ & 4 & & & & 4 & 2 & & & 2 & 22 & & 2 & & . & 1 & 31 & 3 & 1 & & & 6 \\
\hline \multicolumn{6}{|c|}{ FONTE: VERISSIMO, J. 2005.} & & & & & & & & & & & & & & & & \\
\hline${ }^{\star}$ Respostas múltiplas & & & & & & & & & & & & & & & & & & & & & \\
\hline
\end{tabular}


TABELA 9.1: AVALIAÇÃO CÍVICO-REPUBLICANA (CASO E.1), POR PERÍODO DE INÍCIO DE PARTICIPAÇÃO.

\begin{tabular}{|c|c|c|c|c|c|c|c|c|c|c|c|c|c|c|c|c|c|c|}
\hline \multicolumn{19}{|c|}{ Tratamento em outra cidade - E.1* } \\
\hline Período & \multicolumn{5}{|c|}{$\begin{array}{c}\text { período anterior } \\
\text { e/ou até } 1980\end{array}$} & \multicolumn{8}{|c|}{ entre 1981 e 1992} & \multicolumn{5}{|c|}{ depois de 2001} \\
\hline Avaliação & 1 & 4 & 5 & 10 & Total & 1 & 3 & 5 & 6 & 8 & 9 & 10 & Total & 1 & 4 & 5 & 10 & Total \\
\hline $\begin{array}{l}\text { Prefeitura agiu } \\
\text { corretamente }\end{array}$ & 2 & 1 & & 1 & 26 & 3 & & 1 & & & & & 23 & 4 & & & & 14 \\
\hline $\begin{array}{l}\text { Prefeitura agiu de } \\
\text { maneira errada }\end{array}$ & 3 & & 1 & 1 & 18 & & & 2 & 1 & & & 3 & 41 & & 1 & & 4 & 41 \\
\hline $\begin{array}{l}\text { Hospital da cidade } \\
\text { não deveria receber }\end{array}$ & 3 & & 1 & 1 & 18 & & & & & & & & 22 & & & & & 26 \\
\hline $\begin{array}{l}\text { Moradores da } \\
\text { cidadezinha deveriam } \\
\text { reivindicar hospital }\end{array}$ & 1 & & & 4 & 41 & & & 1 & & 1 & 1 & 3 & 52 & & & 1 & 4 & 45 \\
\hline $\begin{array}{l}\text { Moradores da capital } \\
\text { deveriam se unir para } \\
\text { impedir vinda de } \\
\text { pacientes de outra } \\
\text { cidade }\end{array}$ & 4 & & 1 & & 9 & 4 & 1 & 1 & & & & & 12 & 2 & & & 3 & 32 \\
\hline
\end{tabular}

FONTE: VERISSIMO, J. 2005.

${ }^{*}$ Respostas múltiplas 
tABELA 10: AVALIAÇÃo CíviCO-REPUblicana (CASO E.3), POR CONSELHO QUE FAZ PARTE.

\begin{tabular}{|c|c|c|c|c|c|c|c|c|c|c|c|c|c|c|c|c|c|c|c|c|c|c|c|c|}
\hline \multicolumn{25}{|c|}{ Atendimento aos Sem Terra* } \\
\hline Conselho & \multicolumn{6}{|c|}{ VI Prudente } & \multicolumn{5}{|c|}{ Perus } & \multicolumn{6}{|c|}{ Cid Tiradentes } & \multicolumn{7}{|c|}{ Parelheiros } \\
\hline Avaliação & 12 & 23 & 5 & 8 & 10 & Total & 1 & 56 & 8 & 10 & Tota & 1 & 5 & $6 \quad 7$ & 8 & 10 & Total & 1 & $5 \mid 6$ & & 8 & 9 & 10 & Total \\
\hline $\begin{array}{l}1 \text { - atitude } \\
\text { correta, quem } \\
\text { paga imposto } \\
\text { tem prioridade } \\
\text { no atendimento }\end{array}$ & 1 & 1 & 1 & 1 & & 15 & 3 & & & 1 & 13 & 2 & 2 & & & & 7 & 4 & & & & & & 4 \\
\hline $\begin{array}{l}2 \text { - sem terra } \\
\text { deveriam } \\
\text { reivindicar } \\
\text { verbas para gov } \\
\text { do Estado }\end{array}$ & 1 & 1 & & 1 & 1 & 22 & 1 & & & 3 & 31 & 1 & 1 & 1 & & 1 & 23 & 3 & & 1 & & & & 10 \\
\hline $\begin{array}{l}3 \text { - deveriam ter } \\
\text { sido atendidos } \\
\text { de qualquer } \\
\text { maneira }\end{array}$ & & & & 2 & 2 & 36 & & & 1 & 3 & 38 & & 1 & 1 & & 2 & 32 & & & & 2 & & 2 & 36 \\
\hline $\begin{array}{l}4 \text { - deveriam ir } \\
\text { ao CMS } \\
\text { requerer } \\
\text { atendimento }\end{array}$ & & 1 & & & 3 & 33 & 1 & 1 & & 2 & 26 & & & 1 & & 3 & 37 & & & & 1 & 1 & 1 & 34 \\
\hline $\begin{array}{l}5 \text { - CMS, MST e } \\
\text { PM deveria } \\
\text { requerer verbas } \\
\text { para governo do } \\
\text { Estado, para } \\
\text { depois } \\
\text { atenderem os } \\
\text { ST }\end{array}$ & 1 & & & & 3 & 31 & 1 & 1 & & 2 & 26 & 1 & & & 1 & 2 & 29 & 1 & \begin{tabular}{l|l}
1 & 1
\end{tabular} & & & & 1 & 22 \\
\hline
\end{tabular}

FONTE: VERISSIMO, J. 2005.

${ }^{*}$ Respostas múltiplas 
TABELA 10.1: AVALIAÇÃO CíVICO-REPUBLICANA (CASO E.3), POR PERÍODO DE INÍCIO DE PARTICIPAÇÃO.

\begin{tabular}{|c|c|c|c|c|c|c|c|c|c|c|c|c|c|c|c|c|c|c|c|c|}
\hline \multicolumn{21}{|c|}{ Atendimento aos Sem Terra* - E.3 } \\
\hline \multirow{2}{*}{$\begin{array}{l}\text { Período } \\
\text { Avaliação }\end{array}$} & \multicolumn{7}{|c|}{$\begin{array}{c}\text { período anterior e/ou } \\
\text { até } 1980\end{array}$} & \multicolumn{7}{|c|}{ entre 1981 e 1992} & \multicolumn{6}{|c|}{ depois de 2001} \\
\hline & 1 & 3 & 5 & 78 & 9 & 10 & Total & 1 & 5 & 6 & 7 & 8 & 10 & Total & 1 & 5 & 6 & 8 & 10 & Total \\
\hline $\begin{array}{l}1 \text { - atitude correta, } \\
\text { quem paga imposto } \\
\text { tem prioridade no } \\
\text { atendimento }\end{array}$ & 3 & & 1 & . & & & 16 & 5 & 1 & & & & & 10 & 3 & 1 & & & 1 & 18 \\
\hline $\begin{array}{l}2 \text { - sem terra deveriam } \\
\text { reivindicar verbas para } \\
\text { gov do Estado }\end{array}$ & 2 & 1 & 1 & 1 & & & 17 & 3 & & & 1 & & 2 & 30 & 1 & & & 1 & 3 & 39 \\
\hline $\begin{array}{l}3 \text { - deveriam ter sido } \\
\text { atendidos de qualquer } \\
\text { maneira }\end{array}$ & & & 1 & 2 & & 2 & 41 & & & & 1 & 1 & 3 & 55 & & & & 2 & 3 & 38 \\
\hline $\begin{array}{l}4 \text { - deveriam ir ao CMS } \\
\text { requerer atendimento }\end{array}$ & 1 & 1 & & & 1 & 2 & 33 & & & & 2 & 1 & 3 & 51 & & & 1 & & 4 & 46 \\
\hline $\begin{array}{l}5 \text { - CMS, MST e PM } \\
\text { deveria requerer } \\
\text { verbas para governo } \\
\text { do Estado, para depois } \\
\text { atenderem os ST }\end{array}$ & 2 & & & & & 3 & 32 & 2 & 1 & 1 & & 1 & 1 & 31 & & 1 & & & 4 & 45 \\
\hline
\end{tabular}

FONTE: VERISSIMO, J. 2005.

${ }^{*}$ Respostas múltiplas 
TABELA 11: AVALIAÇÃo CívICO-REPUBLICANA (CASO E.4), POR CONSELHO QUE FAZ PARTE.

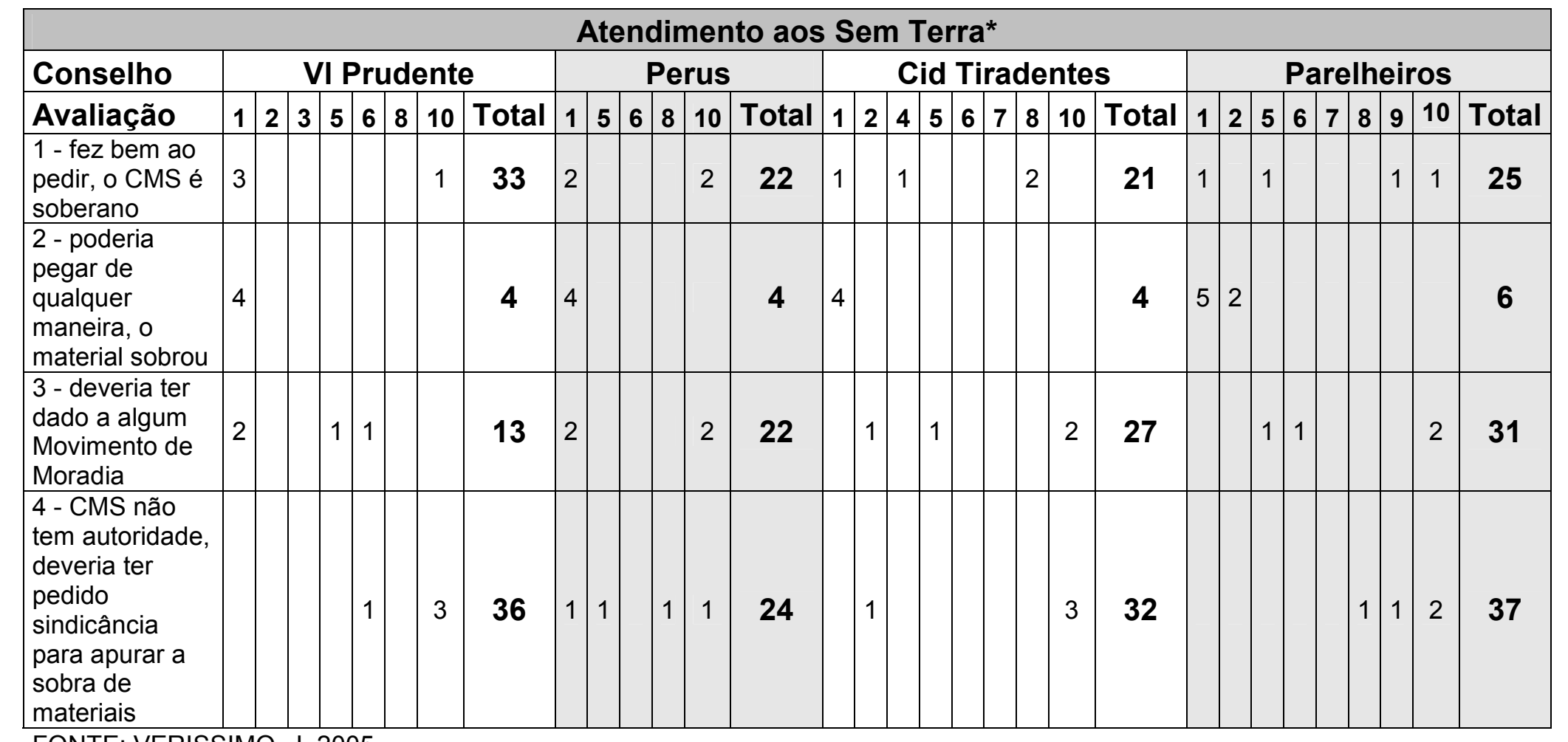

FONTE: VERISSIMO, J. 2005.

${ }^{*}$ Respostas múltiplas 
TABELA 11.1: AVALIAÇÃO CÍVICO-REPUBLICANA (CASO E.4), POR PERÍODO DE INÍCIO DE PARTICIPAÇÃO.

\begin{tabular}{|c|c|c|c|c|c|c|c|c|c|c|c|c|c|c|c|c|c|c|c|c|}
\hline \multicolumn{21}{|c|}{ Doação privada de material público- E. 4* } \\
\hline \multirow{2}{*}{$\begin{array}{l}\text { Período } \\
\text { Avaliação }\end{array}$} & \multicolumn{8}{|c|}{$\begin{array}{c}\text { período anterior e/ou até } \\
1980\end{array}$} & \multicolumn{7}{|c|}{ entre 1981 e 1992} & \multicolumn{5}{|c|}{ depois de 2001} \\
\hline & 1 & 2 & 4 & 5 & 6 & 9 & 10 & Total & 1 & 2 & 5 & 6 & 8 & 10 & Total & 1 & 5 & 8 & 10 & Total \\
\hline $\begin{array}{l}1 \text { - fez bem ao } \\
\text { pedir, o CMS é } \\
\text { soberano }\end{array}$ & 3 & & 1 & & & 1 & & 16 & 2 & & 1 & & 1 & 1 & 25 & 2 & & & 3 & 32 \\
\hline $\begin{array}{l}2 \text { - poderia pegar de } \\
\text { qualquer maneira, o } \\
\text { material sobrou }\end{array}$ & 4 & 1 & & & & & & 6 & 6 & & & & & & 6 & 5 & & & & 5 \\
\hline $\begin{array}{l}3 \text { - deveria ter dado } \\
\text { a algum Movimento } \\
\text { de Moradia }\end{array}$ & & & & & 1 & & 4 & 46 & 1 & 1 & 1 & 1 & & 2 & 35 & 3 & 2 & & & 13 \\
\hline $\begin{array}{l}4 \text { - CMS não tem } \\
\text { autoridade, deveria } \\
\text { ter pedido } \\
\text { sindicância para } \\
\text { apurar a sobra de } \\
\text { materiais }\end{array}$ & & & & 1 & 1 & 1 & 2 & 40 & & 1 & & & 1 & 4 & 50 & 1 & & 1 & 3 & 39 \\
\hline
\end{tabular}

FONTE: VERISSIMO, J. 2005.

*Respostas múltiplas 


\section{ANEXO 01 - QUESTIONÁRIO PARA SELEÇÃO DOS CONSELHEIROS}

Nome:

Idade:

Telefone para contato ( )

Bairro: CEP:

Conselho: segmento:

03 últimos mandatos em conselho(s) do(s) qual(is) já fez parte: (incluir conselhos de unidades e distritais)

01 - ano conselho

02 - ano consleho

03 - ano conselho

O (a) Sr. (a) já participou de:

001( ) Grêmio Estudantil - período de 002( ) Centro Acadêmico - período de 003( ) Associação Atlética - período de 004( ) Empresa Junior - período de

$\overline{\text { de }}_{- \text {período de }}^{a}{ }^{a} \bar{a}-{ }^{a}$

005( ) Outras atividades agremiativas - período de

O (a) Sr. (a) já participou de associações (Pais e Mestres, Associações de Bairro, Sindicatos, OP, Movimentos Sociais, Conselhos, etc)?

006 ( ) - 01 associação

007 ( ) - até 03 associações

008 ( ) - até 05 associações

009 ( ) - mais de 05 associações

Descreva as 03 últimas associações das quais participou (fora conselhos): I

010 - nome da instituição:

011 - período de participação de a

012 - atividade desenvolvida:

13 - cargo que ocupava:

contribuía financeiramente com a instituição: 014 ( )- SIM 015 ( )- NÃO

II

016 - nome da instituição:

017 - período de participação de

018 - atividade

desenvolvida:

019 - cargo que ocupava:

contribuía financeiramente com a instituição: 020 ( )- SIM 021 ( )- NÃO 
III

022 - nome da instituição:

023 - período de participação de

a

024 - atividade desenvolvida:

025 - cargo que ocupava:

contribuía financeiramente com a instituição: 026 ( )- SIM 027 ( )- NÃO

O(a) Sr. (a ) participa de algum partido político?

028 ( ) - SIM 029 ( ) - NÃO 030( )-Simpatizante

031 - qual partido?

exerce cargo no partido?

032 ( ) SIM

033 ( ) NÃO

034 ( ) já exerci

035 - Há quanto tempo está (esteve) no partido? De contribui financeiramente com o partido?

036 ( ) SIM $\quad 037$ ( ) NÃO $\quad 038$ ( ) já contribuí

freqüenta as reuniões do partido:

039 ( ) - semanalmente

040 ( ) - quinzenalmente

041 ( ) - mensalmente

042 ( ) - semestralmente

043 ( ) - outras

Qual sua escolaridade?

044 ( ) $1^{\circ}$ grau incompleto

045 ( ) $1^{\circ}$ grau completo

046 ( $) 2^{\circ}$ grau incompleto

047 ( ) $2^{\circ}$ grau completo

048 ( )superior incompleto

049 ( )superior completo

050 ( )pós-graduação

Qual a sua ocupação:

051 ( ) - assalariado do setor privado

052 ( ) - assalariado do setor público

053 ( ) - autônomo

054 ( ) - aposentado/pensionista

055 ( ) - prendas domésticas

056 ( ) - desempregado

Qual a sua renda:

057 - individual: R\$

058 - familiar: R\$ 


\section{ANEXO 02 - QUESTIONÁRIO PARA CONSELHEIROS SELEICIONADOS}

\section{I - Avaliação do entorno do local de moradia}

A.1. Onde você nasceu?

1. NOME DA CIDADE:

2. Estado:

3. (SE SÃO PAULO): Bairro:

77. NR

88. NA

99. NS

A.2. Há quanto tempo você mora nesta (casa / apartamento), ou você mora nesta (casa / apartamento) desde que nasceu? (SE SÃO PAULO A.4)

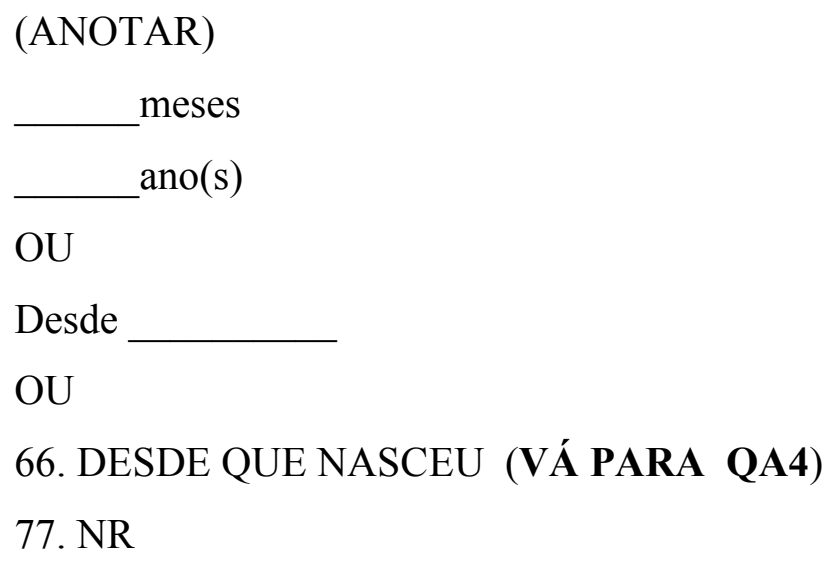

$\mathrm{OU}$

Desde

$\mathrm{OU}$

66. DESDE QUE NASCEU (VÁ PARA QA4)

77. NR

A.3. Há várias razões que levam as pessoas a se mudarem para determinada cidade. Qual foi a principal razão que o (a) levou a se mudar para São Paulo?(ANOTAR) (NÃO LER OPÇÕES)? E em segundo lugar? (ANOTAR) (NÃO LER OPÇÕES)

1. Oportunidade de trabalho

2. Escolas (melhores, mais vagas, qualificação em nível técnico e superior)

3. Moradia mais barata

4. Tamanho da cidade (por ser uma cidade menor)

5. Tamanho da cidade (por ser uma cidade maior)

6. Facilidade de transporte

7. Vida mais tranqüila (menos violência, crime)

8. Vida mais tranqüila (menos trânsito, barulho)

9. Perto de amigos ou parentes

10. Parques ou áreas verdes 
11. Vida cultural

12. Porque se mudou, quando criança, com a família

13. Do campo para a cidade (por exemplo: porque era pequeno proprietário rural ou posseiro e perdeu a terra)

14. Outra (ANOTAR):

77. NR 88. NA 99. NS

A.4. Gostaria de falar agora sobre a qualidade de vida em São Paulo. De maneira geral, você acha que a qualidade de vida aqui é boa ou ruim?

(SE BOA, PERGUNTAR): Você acha que ela é muito boa ou boa?

1. Muito boa

2. Boa

3. Regular (SE VOLUNTARIAMENTE)

(SE RUIM, PERGUNTAR): Você acha que ela é ruim ou muito ruim?

4. Ruim

5. Muito ruim

7. NR

9. NS

A.5. E no/na seu/sua (bairro/vila)? De maneira geral, você acha que a (qualidade de vida / vida) aqui é boa ou ruim?

(SE BOA, PERGUNTAR): Você acha que ela é muito boa ou boa?

1. Muito boa

2. Boa

3. Regular (SE VOLUNTARIAMENTE)

(SE RUIM, PERGUNTAR): Você acha que ela é ruim ou muito ruim?

4. Ruim

5. Muito ruim

7. NR

9. NS

A.6. Agora vamos falar sobre a situação do meio ambiente no/na seu/sua (bairro/vila).

A.6.1 Em uma escala de 1 a 10, onde 1 quer dizer poucas árvores e 10 muitas árvores, que nota você dá para a quantidade de árvores no/na seu/sua (bairro/vila) você diria que ela é...?

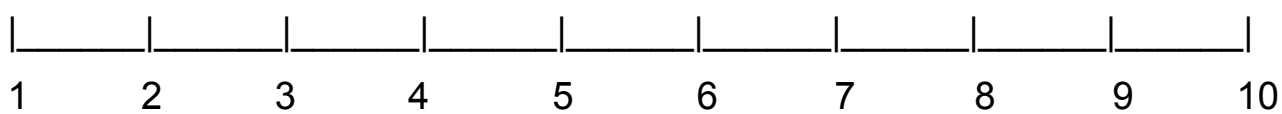


99. NS

77. NR

A.6.2 Em uma escala onde 1 quer dizer que as/os (ruas / becos) são mal conservados (as) (com buracos, sem bueiros, sem boca de lobo), e 10 quer dizer que as (ruas / becos) são bem conservados, que nota você dá á conservação das (ruas/becos) no/na seu/sua (bairro/vila)?

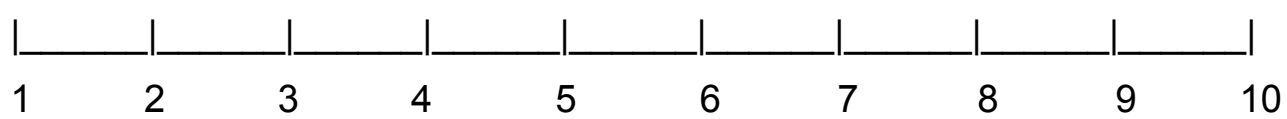

99. NS 77. NR

A.6.3 Em uma escala onde 1 quer dizer muito trânsito e 10 pouco trânsito, que nota você dá para o trânsito no/na seu/sua (bairro/vila)?

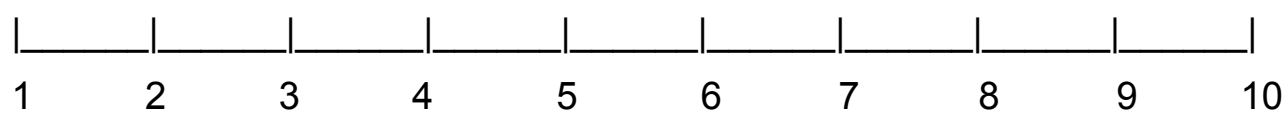

99. NS 77. NR

A.6.4 No/na seu/sua (bairro/vila) há córregos ou lagoas próximos?

$1-\operatorname{SIM} \quad 2-\mathrm{NÃO}$

(SE SIM, PERGUNTAR):

Em uma escala onde 1 quer dizer muita poluição dos córregos ou lagoas, e 10 não há poluição dos córregos ou lagoas, qual é a qualidade da água dos córregos ou lagoas próximos ao/à seu/sua (bairro/vila)?

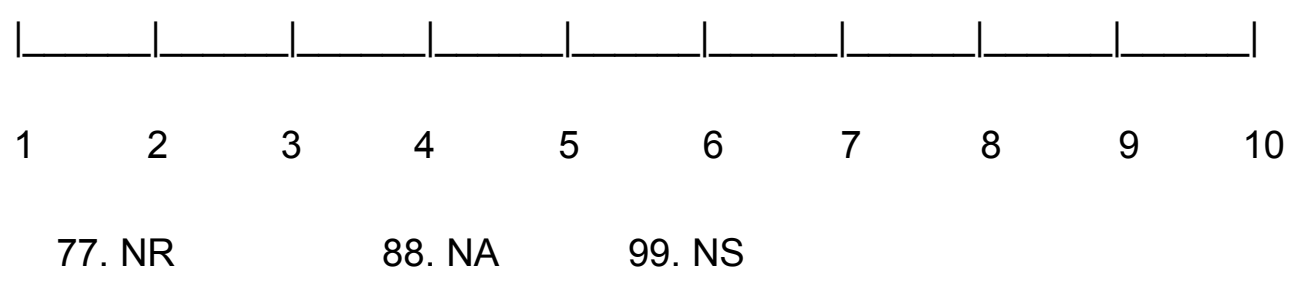

A.7. Agora vamos falar sobre a situação dos seguintes serviços no/na seu/sua (bairro/vila).

(LER UMA OPÇÃO POR VEZ) .....é um problema muito grave, é um problema grave, é um problema pouco grave, ou não é um problema? 
a. No/na seu/sua (bairro / vila) a $\begin{array}{ccccc}\text { Problema } & \begin{array}{c}\text { Problema } \\ \text { grave }\end{array} & \begin{array}{c}\text { Problema } \\ \text { pouco } \\ \text { grave }\end{array} & \begin{array}{c}\text { Não é } \\ \text { problema }\end{array} & \text { NR }\end{array}$ NS falta de vagas em escolas ou creches é ...

b. A falta de comércio ou serviços (bancos supermercados, agência de correio) é ...

2

3

4

$7 \quad 9$

c. O lixo (a coleta de lixo, o lixo nas ruas) é ....

1

2

3

4

$\begin{array}{ll}7 & 9\end{array}$

d. No/na seu/sua (bairro / vila) o saneamento (a falta de esgoto, esgoto a céu aberto) é ...

1

2

3

4

$7 \quad 9$

e. A falta de policiamento é ...

f. A falta de áreas de lazer (como praças, quadras esportivas, parques etc) é ...

1

2

3

4

7

9

g. No/na seu/sua (bairro / vila) o transporte público (os horários, os preços da passagem, ônibus

1

2

3

4

$7 \quad 9$

h. A falta de postos de saúde

1

2

3

4

7

9

i. A falta de hospitais

j. A falta de ambulatórios de especialidades (mulheres, idosos, saúde mental,etc)

h. A falta de bons profissionais na saúde

i. Outros 


\section{II - Avaliação do capital social, associativismo, participação e valores pós-materialistas}

B.1. São várias as coisas que as pessoas podem fazer para resolver problemas no/a seu/sua (bairro / vila) ou vizinhança. Nos últimos doze meses, você participou de alguma reunião com representantes da Prefeitura, (nas Subprefeituras, conselhos) ou secretarias municipais para resolver problemas do/a seu/sua (bairro / vila) ou de São Paulo?
1. Sim
2. Não
77. NR
99. NS

B.2. Nos últimos doze meses, você se reuniu com vizinhos para discutir problemas do/da (bairro / vila)?
1. $\operatorname{Sim}$
2. Não
77. NR
99. NS

B.3. Com qual dessas afirmativas você concorda?

\section{(LER OPÇÕES 1 A 3)}

1. Você se sente em casa neste/a (bairro / vila),

2. Este/a (bairro / vila) é apenas um lugar para morar, ou

3. Se pudesse, você mudaria deste/a (bairro / vila)?

77. NR

99. NS

B.4 Com que freqüência você conversa com seus vizinhos?

(LER OPÇÕES 1 A 4)

1. Todos os dias ou quase todos os dias,

2. Toda semana (semanalmente),

3. Todo mês (mensalmente), ou

4. Quase nunca? 
77.NR 88.NA 99.NS

B.5 Com que freqüência você e os seus vizinhos fazem favor uns aos outros? Por fazer um favor, quero dizer coisas como cuidar dos filhos, emprestar mantimentos, levar filhos para a escola, ou outro tipo de ajuda. Isto acontece ...

1. Sempre,

2. Às vezes,

3. Raramente, ou

4. Nunca?

77.NR

99.NS

B.6. Agora vou ler uma série de afirmativas e gostaria de saber se você concorda ou discorda de cada uma delas.

6.a. Pode-se confiar nas pessoas que moram neste/nesta (bairro / vila). Você concorda ou discorda?

1. Concorda totalmente

2. Concorda em parte

3. Discorda em parte

4. Discorda totalmente

77. NR

99. NS

6.b. Os vizinhos neste/nesta (bairro / vila) são pessoas muito prestativas. Você concorda ou discorda?

1. Concorda totalmente

2. Concorda em parte

3. Discorda em parte

4. Discorda totalmente

77. NR

99. NS

B.7. Vou apresentar algumas atividades que você pode fazer durante o seu tempo livre ou de lazer. Eu gostaria de saber se você .... (LER UMA OPÇÃO POR VEZ) .... sempre, às vezes, raramente ou nunca? 


\section{Sempre Às vezes Raramente Nunca NR NS}

a. Visita amigos e parentes

1

2

3

4

7

9

b. Vai a bares ou restaurantes

1

2

3

4

7

9

c. Lê revistas ou livros

1

2

3

4

7

9

d. Vai ao cinema

1

2

3

4

7

9

e. Vai a festas (de amigos, parentes, de igreja, de associações, etc)

1

2

3

4

7

9

e. Passeia em praças

1

2

3

4

7

9

f. Passeia em cachoeiras, reservas naturais

12

3

4

7

9

g. Pratica esportes ou fazer exercícios

1

2

3

4

7

9

h. Vai ao estádio de futebol

1

2

3

4

7

9

i. Vai à Igreja

j. Fica em casa
2

2
3

3
4

4
$7 \quad 9$

$7 \quad 9$

B.8. Agora eu gostaria de saber sobre o uso que você faz de meios de comunicação como jornal, rádio e televisão. Com que freqüência você lê jornal:

1. Diariamente ou quase todos os dias,

2. Algumas vezes por semana,

3. Quase nunca, ou

4. Você não lê jornal?

77. NR 88. NA (não sabe ler) 99. NS 
B.9. Com que freqüência você assiste televisão? Você assiste diariamente, algumas vezes por semana, quase nunca ou você não assiste televisão?

(SE DIARIAMENTE): Aproximadamente: (LER OPÇÕES 1 A 4)

1. Acima de 8 horas,

2. De 5 a 8 horas,

3. De 2 a 5 horas, ou

4. Até 2 horas?

5. Algumas vezes por semana

6. Quase nunca

7. Você não assiste televisão

77. NR

99. NS

B.10. Com que freqüência você escuta rádio? Você escuta rádio diariamente, algumas vezes por semana, quase nunca ou você não escuta rádio?

(SE DIARIAMENTE): Aproximadamente: (LER OPÇÕES 1 A 4)

1. Acima de 8 horas,

2. De 5 a 8 horas,

3. De 2 a 5 horas, ou

4. Até 2 horas?

5. Algumas vezes por semana

6. Quase nunca

7. Você não escuta rádio

77. NR

99. NS

B.11. Apesar de sabermos que o uso da Internet ainda é pequeno, gostaríamos de lhe perguntar se você já usa a Internet?

1. Sim

2. Não (VÁ PARA C.1)

77. NR

99. NS (NÃO SABE O QUE É) (VÁ PARA C.1)

B.11.1 (se sim) Você usa a internet para.... (LER UMA OPÇÃO POR VEZ DE a A h) 
88 NA 99 NS

\section{Sim Não NR}
a. Ler as notícias do dia
$\begin{array}{lll}1 & 2 & 77\end{array}$
b. Fazer amigos
c. Comunicar-se com amigos ou parentes
$\begin{array}{lll}1 & 2 & 77\end{array}$
d. Trabalhar, estudar ou pesquisar
$\begin{array}{lll}1 & 2 & 77\end{array}$
e. Fazer compras
f. Trocar idéias ou participar de grupo
$\begin{array}{lll}1 & 2 & 77\end{array}$
$\begin{array}{lll}1 & 2 & 77\end{array}$
de atividade que lhe interessa (esporte, política, religião, etc)
g. Para jogos, programa de música, etc
$\begin{array}{lll}1 & 2 & 77\end{array}$
h. Grupos de discussão política

$\begin{array}{lll}1 & 2 & 77\end{array}$
h. Algum outro?:

\section{III - Avaliação de Participação Política e Associativismo}

\section{C.1. Você participa de:}

Participa esporadicamente

1.

Não participa

2.

É membro, participa formalmente

3.

Já participou e não participa mais

4.

NS

99

NR

77

C.1.1 Entidade beneficente ou de caridade (cujo principal objetivo é o de ajudar o outro e não o de promover o interesse ou a identidade do próprio participante)

$$
\begin{array}{lllllll}
1 & 2 & 3 & 4 & 77 & 88 & 99
\end{array}
$$

\section{C.1.1.b Qual?}

C.1.1.c Contribui financeiramente para instituição? 1SIM 2 NÃO

C.1.1.d nos últimas 12 meses, você esteve na instituição 1 - mais de $12 \times$ 2-mais $06 \mathrm{X}$ 3- menos de 06X

C.1.2 Entidade/Associação recreativa e/ou esportiva

$\begin{array}{lllllll}1 & 2 & 3 & 4 & 77 & 88 & 99\end{array}$




\section{C.1.2.b Qual?}

C.1.2c Contribui financeiramente para instituição? 1SIM 2 NÃO

C.1.2d nos últimas 12 meses, você esteve na instituição 1 - mais de $12 \times$ 2-mais $06 \mathrm{X}$ 3- menos de 06X

C.1.3 Entidade/Associação ligada à defesa dos direitos humanos (mulheres, adolescentes, idosos, negros, homossexuais, portadores de deficiências, ou outras):

\section{$\begin{array}{lllllll}1 & 2 & 3 & 4 & 77 & 88 & 99\end{array}$}

\section{C.1.3b Qual(is)?}

C.1.3c Contribui financeiramente para instituição? 1SIM

C.1.3 d nos últimas 12 meses, você esteve na instituição 1 -mais de $12 \mathrm{X}$ 2-mais $06 \mathrm{X}$ 3- menos de 06X

C.1.4 Entidade/Associação ligada à defesa dos consumidores

$\begin{array}{lllllll}1 & 2 & 3 & 4 & 77 & 88 & 99\end{array}$

C.1.4.b

Qual?

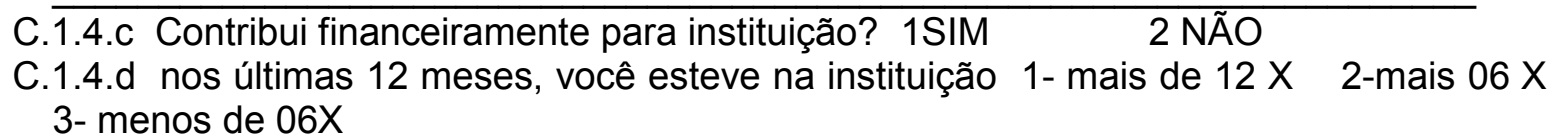

C.1.5 Associação religiosa ou Igreja

$\begin{array}{lllllll}1 & 2 & 3 & 4 & 77 & 88 & 99\end{array}$

\section{C.1.5.b}

Qual?

C.1.5.c Contribui financeiramente para instituição? 1SIM 2 NÃO

C.1.5.d nos últimas 12 meses, você esteve na instituição 1 -mais de $12 \times$ 2-mais $06 \mathrm{X}$ 3- menos de 06X

C.1.6 Grupos de Fé e política (pastorais, por exempo)

$$
\begin{array}{lllllll}
1 & 2 & 3 & 4 & 77 & 88 & 99
\end{array}
$$

\section{C.1.6.b}

Qual?

C.1.6.c Contribui financeiramente para instituição? 1SIM 2 NÃO

C.1.6.d nos últimas 12 meses, você esteve na instituição 1 - mais de $12 \mathrm{X}$ 2-mais $06 \mathrm{X}$ 3- menos de 06X 
C.1.7 Associações de Moradia

$\begin{array}{lllllll}1 & 2 & 3 & 4 & 77 & 88 & 99\end{array}$

C.1.7.b

Qual?

C.1.7.c Contribui financeiramente para instituição? 1SIM 2 NÃO

C.1.7.d nos últimas 12 meses, você esteve na instituição 1 -mais de $12 \mathrm{X}$ 2-mais $06 \mathrm{X}$ 3- menos de 06X

C.1.8 Partido Politico

$\begin{array}{lllllll}1 & 2 & 3 & 4 & 77 & 88 & 99\end{array}$

C.1.8.b

Qual?

C. 1.8.c Contribui financeiramente para instituição? 1SIM 2 NÃO

C.1.8.d nos últimas 12 meses, você esteve na instituição 1 -mais de $12 \mathrm{X}$ 2-mais $06 \mathrm{X}$ 3- menos de 06X

C.1.9 Associação de Saúde

$\begin{array}{lllllll}1 & 2 & 3 & 4 & 77 & 88 & 99\end{array}$

C.1.9.b

Qual?

C.1.9.c Contribui financeiramente para instituição? 1SIM 2 NÃO

C.1.9.d nos últimas 12 meses, você esteve na instituição 1 -mais de $12 \mathrm{X}$ 2-mais $06 \mathrm{X}$ 3- menos de 06X

C. 1.10 Associação ligada à educação

$\begin{array}{lllllll}1 & 2 & 3 & 4 & 77 & 88 & 99\end{array}$

C.1.10.b

Qual?

C.1.10.c Contribui financeiramente para instituição? 1SIM 2 NÃO

C.1.10d nos últimas 12 meses, você esteve na instituição 1 -mais de $12 X$ 2-mais $06 \mathrm{X}$ 3- menos de 06X

C.1.11 Associação ligada ao meio ambiente

$$
\begin{array}{lllllll}
1 & 2 & 3 & 4 & 77 & 88 & 99
\end{array}
$$

C.1.11.b

Qual?

C.1.11.c Contribui financeiramente para instituição? 1SIM 2 NÃO

C.1.11.d nos últimas 12 meses, você esteve na instituição 1 - mais de $12 X$ 2-mais $06 X$ 3- menos de 06X

C.1.12 Associação ligada à cultura 
C.1.12.c Contribui financeiramente para instituição? 1SIM 2 NÃO

C.1.12.d nos últimas 12 meses, você esteve na instituição 1 - mais de $12 \mathrm{X}$ 2-mais $06 \mathrm{X}$ 3- menos de 06X

C.1.13 outros tipos de associações

$$
\begin{array}{lllllll}
1 & 2 & 3 & 4 & 77 & 88 & 99
\end{array}
$$

C.1.13.c Contribui financeiramente para instituição? 1SIM 2 NÃO

C.1.13.d nos últimas 12 meses, você esteve na instituição 1 - mais de $12 \mathrm{X}$ 2-mais $06 \mathrm{X}$ 3- menos de 06X

C.1.14 entidades empresariais e patronais

$$
\begin{array}{lllllll}
1 & 2 & 3 & 4 & 77 & 88 & 99
\end{array}
$$

C. 1.14.c Contribui financeiramente para instituição? 1SIM 2 NÃO

C.1.14.d nos últimas 12 meses, você esteve na instituição 1 - mais de $12 \mathrm{X}$ 2-mais $06 \mathrm{X}$ 3- menos de 06X

C.1.15 entidade estudantil

$\begin{array}{lllllll}1 & 2 & 3 & 4 & 77 & 88 & 99\end{array}$

\section{C.1.15.b}

Qual?

C.1.15.c Contribui financeiramente para instituição? 1SIM 2 NÃO

C.1.15.d nos últimas 12 meses, você esteve na instituição 1 - mais de $12 X$ 2-mais $06 \mathrm{X}$ 3- menos de 06X

C.1.16 associação de auto ajuda

$$
\begin{array}{lllllll}
1 & 2 & 3 & 4 & 77 & 88 & 99
\end{array}
$$

C.1.16.c Contribui financeiramente para instituição? 1SIM 2 NÃO

C.1.16.d nos últimas 12 meses, você esteve na instituição 1 - mais de $12 \mathrm{X}$ 2-mais $06 \mathrm{X}$ 3- menos de 06X

C.1.17 sindicato de trabalhadores 
C.1.13.c Contribui financeiramente para instituição? 1SIM 2 NÃO

C.1.13.d nos últimas 12 meses, você esteve na instituição 1 - mais de $12 X$ 2-mais $06 \mathrm{X}$ 3- menos de 06X

C.1.18 associação profissional

$\begin{array}{lllllll}1 & 2 & 3 & 4 & 77 & 88 & 99\end{array}$

c.1.13.c Contribui financeiramente para instituição? 1SIM 2 NÃO

C.1.13.d nos últimas 12 meses, você esteve na instituição 1 - mais de $12 \mathrm{X}$ 2-mais $06 \mathrm{X}$ 3- menos de 06X

C.1.19. O principal motivo que a/o levou a participar da/do associação de saúde foi:

1. Vontade de ajudar os outros (as crianças, os idosos, os pobres, os doentes, outros),

2. Cooperar com o seu grupo (de vizinhos, colegas de trabalho, étnico, de mulheres etc.) na busca de melhorias nesta área

3. Cooperar na busca de melhorias coletivas para a sua cidade, país ou mundo,

4. Aumentar as benfeitorias de saúde da sua comunidade,

5. Porque você tinha uma necessidade de atendimento de saúde que não estava sendo cumprida

6. Defender as idéias nas quais você acredita, ou o que você acha justo.

7. Outro motivo. Qual?

77. NR 88. NA 99. NS

C.1.20. (APENAS PARA OS QUE NÃO PARTICIPAM DE NENHUMA ENTIDADE ATUALMENTE) Para nosso estudo também é importante saber os motivos pelos quais as pessoas não participam de grupos, associações ou partidos. Qual é o principal motivo porque você não participa? Você não participa porque....

(LER OPÇÕES 1 A 8 - MARQUE APENAS UMA)

1. Não tem interesse em participar

2. Não tem tempo

3. Não tem recursos (dinheiro, informação, habilidades, etc) 
4. Não adianta/ não resolve nada

5. Não precisa (não tem necessidade)

6. Outros participam e resolvem o assunto

7. Prefere resolver sozinho os próprios assuntos

8. Espera que o governo resolva o(s) problema(s)

9. Outro motivo (ANOTAR)

77. NR 88. NA 99. NS

C.1.21 C.1.20. (APENAS PARA OS PARTICIPARAM E NÃO PARTICIPAM MAIS DE QUALQUER ASSOCIAÇÃO CITADA) Para nosso estudo também é importante saber os motivos pelos quais as pessoas deixam de participar de grupos, associações ou partidos. Qual é o principal motivo porque você deixou de participar? Você deixou de participar porque....

(LER OPÇÕES 1 A 8 - MARQUE APENAS UMA)

1. Perdeu o interesse em participar

2. Não tem mais tempo

3. Não tem mais recursos (dinheiro, informação, habilidades, etc)

4. Não adiantou/ não resolveu nada

5. Não precisou mais (não tem necessidade)

6. Outros participam e resolvem o assunto

7. Prefere resolver sozinho os próprios assuntos

8. Espera que o governo resolva o(s) problema(s)

9. Outro motivo (ANOTAR)

77. NR 88. NA 99. NS

C.2. Vou ler uma lista de atividades e gostaria de saber com qual freqüência você as faz. Com que freqüência você ... (LER UMA OPÇÃO POR VEZ) .... sempre, às vezes, raramente ou nunca?.

Sempre Às vezes Raramente Nunca NR NA NS

\begin{tabular}{|c|c|c|c|c|c|c|}
\hline a. Assiste noticiário na televisão & 1 & 2 & 3 & 4 & 7 & 8 \\
\hline b. Lê sobre política nos jornais & 1 & 2 & 3 & 4 & 7 & 8 \\
\hline $\begin{array}{l}\text { c. Conversa sobre política com } \\
\text { os amigos }\end{array}$ & 1 & 2 & 3 & 4 & 7 & 8 \\
\hline
\end{tabular}



d. Participa de reuniões para
1
2
3
4
$7 \quad 8$

C.3. Você participa de:

1. Conselhos gestores de unidades de saúde

2. Conselho Municipal de Saúde

3 Conselhos Gestores de Saúde da Subprefeitura

4. Conselho Estadual de Saúde

5. Conselho Federal de Saúde

77. não respondeu

99. NS

C.4. Na sua opinião, com os Conselhos de Saúde as chances da população decidir sobre as obras de saúde na sua região aumentam, diminuem ou continuam iguais?

1. Aumentou

2. Diminuiu

3. Continua igual

77. NR

99. NS (SE VOLUNTARIAMENTE)

C.5. Na sua opinião, com os Conselhos de Saúde, a prestação de contas das Subprefeituras junto à população aumentou, diminuiu, ou continua igual?

1. Aumentou $77 \mathrm{NR}$

2. Diminuiu 99 NS (SE VOLUNTARIAMENTE)

3. Continua igual

C.6. Com os Conselhos de Saúde, a atenção que as Subprefeituras dão às demandas da população aumentou, diminuiu, ou continua igual?

1. Aumentou $77 \mathrm{NR}$

2. Diminuiu 99 NS (SE VOLUNTARIAMENTE)

3. Continua igual

C.7. Com os Conselhos de Saúde, o poder dos vereadores aumentou, diminuiu, ou continua igual?

1. Aumentou $77 \mathrm{NR}$

2. Diminuiu 99 NS (SE VOLUNTARIAMENTE) 
3. Continua igual

C.8. Você já participou de conselhos de saúde antes?
1. SIM
77. NR
2. NÃO
99. NS

C.9. (SE SIM) Em que período você participou? Você participou ... (LER OPÇÕES 1 A 3) (MARCAR UMA OU MAIS)
1. Entre 89 e 92 (governo Erundina),
Sim Não NR NA NS
2. A partir de 2001 até hoje (governo Marta)
$\begin{array}{lllll}1 & 2 & 77 & 88 & 99\end{array}$
$\begin{array}{lllll}1 & 2 & 77 & 88 & 99\end{array}$

C.10. Na sua opinião, a organização do Conselho de Saúde tem sido:

1. Muito democrática,

77. NR

2. Democrática,

99. NS

3. Pouco democrática, ou

4. Nada democrática?

\section{IV - Avaliação de Valores Políticos}

D.1. De maneira geral, você diria que podemos confiar na maioria das pessoas, ou você acha que cuidado nunca é demais?

1. Podemos confiar na maioria das pessoas

77. NR

2. Cuidado nunca é demais

99. NS

D.2 Eu vou ler uma lista de coisas que podem ser importantes para ensinarmos às crianças em casa. Dentre essas coisas, quais são as duas que você considera mais importantes?

(LER OPÇÕES a A d) 


\begin{tabular}{|l|c|c|c|c|}
\hline & Mencionou & $\begin{array}{c}\text { Não } \\
\text { mencionou }\end{array}$ & NR & NS \\
\hline a. Ser independente, & 1 & 2 & 77 & 99 \\
\hline b. Ser obediente, & 1 & 2 & 77 & 99 \\
\hline c. Ter determinação, e lutar pelos seus & 1 & 2 & 77 & 99 \\
direitos & 1 & 2 & 77 & 99 \\
\hline d. Ter religião? & & & & 97 \\
\hline
\end{tabular}

D.2.1 Vou ler algumas diferentes formas de ação política que as pessoas podem adotar. Gostaria que você dissesse se já fez alguma dessas ações, se você poderia fazê-las, ou se nunca, em nenhuma circunstância, o faria.

$\begin{array}{lccc}\text { Já fez } & \begin{array}{c}\text { Poderia } \\ \text { fazer }\end{array} & \begin{array}{c}\text { Nunca } \\ \text { Faria }\end{array} & \text { NR }\end{array} \quad$ NS

a. Assinar um manifesto (abaixo assinado).

$\begin{array}{lllll}1 & 2 & 3 & 77 & 99\end{array}$

b. Participar de boicote (por ex., deixar de comprar produto de determinada marca como forma de protesto).

c. Participar de manifestações ou passeatas.

$\begin{array}{lllll}1 & 2 & 3 & 77 & 99\end{array}$

d. Participar de greves.

$\begin{array}{lllll}1 & 2 & 3 & 77 & 99\end{array}$

e. Ocupar prédios, fábricas, lotes, escolas.

$\begin{array}{lllll}1 & 2 & 3 & 77 & 99\end{array}$

D.3.Se você tivesse que escolher, qual dessas coisas você diria que é a mais importante? $\mathrm{E}$ qual seria a segunda mais importante?

1. Manter a ordem no país

a.

Mais importante b. Segunda mais importante 
2. Aumentar a participação das pessoas em decisões importantes do governo

3. Combater a inflação (alta de preços)

4. Proteger a liberdade de expressão (o direito das pessoas

4 de dizerem o que pensam sem censura do governo)

4

5. Manter acesso público a serviços como saúde e educação

77. NR

99. NS (SE VOLUNTARIAMENTE)

D.4. Agora eu vou ler uma lista de várias mudanças que podem acontecer em nosso modo de vida em um futuro próximo. Você acha que... (LER UMA OPÇÃO POR VEZ)...seria uma coisa boa, uma coisa ruim, ou não faria diferença para você?

\section{Boa}

a. Se as pessoas vierem a dar menos importância ao dinheiro e as posses materiais.

b. Se o trabalho deixar de ser a coisa mais importante na vida das pessoas.

c. Se as pessoas vierem a ter mais respeito pelasautoridades.

d. Se houvesse participação popular para todas as ações do governo.
Ruim

1

1

1

2

2

2
Não faria diferença
NR
3

7

3

7

3
NS

9

D.5. Você pensa que a homossexualidade é sempre aceitável, nunca é aceitável, ou você tem alguma opinião intermediária? Nesta escala de resposta, 1 significa nunca aceitável e 10 sempre aceitável.

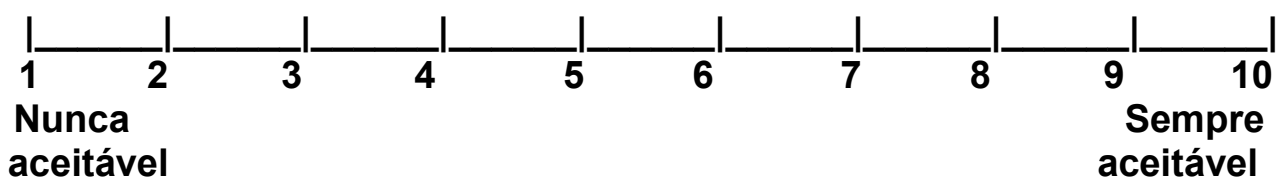

NR. 77

NS. 99 
D.6.E em relação ao aborto? Você pensa que o aborto é sempre aceitável, nunca é aceitável, ou você tem alguma opinião intermediária? Nesta escala de resposta, 1 significa nunca aceitável e 10 sempre aceitável.

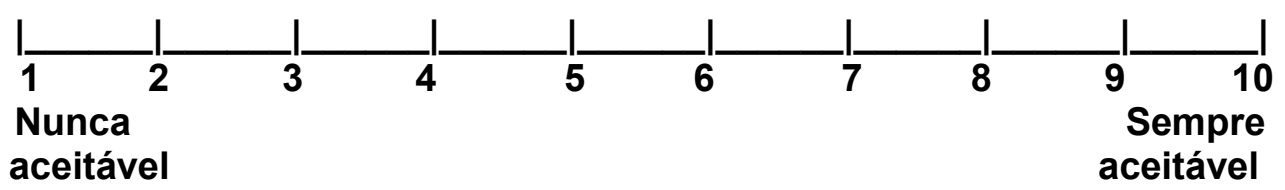

NR. 77

NS. 99

D.7. E em relação a ser brasileiro(a)? Como você se considera?

1. Muito orgulhoso (a)

77. NR

2. Orgulhoso (a)

88. NA (NÃO É BRASILEIRO(A))

3. Não muito orgulhoso (a)

99. NS

4. Nada orgulhoso (a) de ser brasileiro (a)

D.8. O que você pensa de cada uma dessas maneiras de governar um país? Você acha que (LER UMA OPÇÃO POR VEZ) .... é uma maneira muito boa, boa, ruim ou muito ruim de governar um país?

$\begin{gathered}\text { Muito } \\ \text { boa }\end{gathered}$
Boa
a. Ter um líder forte e com poder, que não
1
2
3
4
77
99 e com as eleições.
b. Ter técnicos especialistas, e não os políticos tomando as decisões.
c. Ter um governo militar.
d. Ter um regime político democrático.
e. O povo é quem tem que governar

$\begin{array}{llllll}1 & 2 & 3 & 4 & 77 & 99 \\ 1 & 2 & 3 & 4 & 77 & 99 \\ 1 & 2 & 3 & 4 & 77 & 99 \\ 1 & 2 & 3 & 4 & 77 & 99\end{array}$

D.9. Todos temos diferentes sentimentos em relação à política. Em você, a política causa:

1. aborrecimento

2. entusiasmo

3. irritação

4. interesse

5. indiferença

6. paixão 
7. desgosto

8. compromisso

9. desconfiança

10. nenhum dos anteriores

11. outros

$77 \mathrm{NR} \quad 99 \mathrm{NS}$

D.10 Como você se sente ao andar à noite nas ruas da sua vizinhança? Você se sente seguro (a) ou inseguro (a)?
1. Muito seguro(a)
2. Seguro(a)
3. Inseguro(a)
4. Muito inseguro(a)
77. NR
99. NS

D.11 Pensando na atuação da Polícia Militar (PM) em sua vizinhança, você ...

1. Confia muito,

2. Confia,

3. Confia pouco, ou

4. Não confia na atuação da Polícia Militar na sua vizinhança?

$\begin{array}{ll}\text { 77. NR } & \text { 89. NA }\end{array}$

D.12 Pensando na resolução de problemas de violência em sua vizinhança, você diria que a Polícia Militar (PM) é ...

1. Muito eficiente,

2. Eficiente,

3. Pouco eficiente, ou

4. Nada eficiente?

77. NR 88. NA 99. NS

D.13 Você acha que no seu bairro existe ...

1. Um número grande de policiais militares corruptos

2. Um número razoável de policiais militares corruptos

3. Um número pequeno de policiais militares corruptos

4. Não existem policiais militares corruptos

77. NR 88.NA 99. NS 
D.14 Você acha que no seu bairro o modo como a Polícia Militar trata as pessoas ricas é muito melhor, é um pouco melhor, é do mesmo jeito, é um pouco pior ou é muito pior do que o modo como ela trata as pessoas pobres?

1. Muito melhor

2. Um pouco melhor

3. Do mesmo jeito

4. Um pouco pior

5. Muito pior
77. NR
88. NA
99. NS

D.15 Como você se sente ao precisar de atendimento à saúde na sua vizinhança? Você se sente seguro (a) ou inseguro (a)?
1. Muito seguro(a)
2. Seguro(a)
3. Inseguro(a)
4. Muito inseguro(a)
77. NR
99. NS

D.16 Pensando na atuação dos médicos dos postos de saúde e hospitais em sua vizinhança, você ...
4. Confia muito,
5. Confia,
6. Confia pouco, ou
4. Não confia na atuação dos médicos?
77. NR
88. NA
99. NS

D.17 Pensando na resolução de seus problemas de saúde em sua vizinhança, você diria que as unidades de saúde (postos, hospitais, caps, etc) são ...

5. Muito eficientes,

6. Eficientes,

7. Pouco eficientes, ou

8. Nada eficientes? 
77. NR 88. NA 99. NS

D.18 Você acha que no seu bairro existe:

5. Um número grande de profissionais da saúde desonestos

6. Um número razoável de profissionais da saúde desonestos

7. Um número pequeno de profissionais da saúde desonestos

8. Não existem profissionais da saúde desonestos
77.NR
88.NA
99. NS

D.19 Você acha que no seu bairro o modo como os médicos e/ou enfermeiras tratam as pessoas ricas é muito melhor, é um pouco melhor, é do mesmo jeito, é um pouco pior ou é muito pior do que o modo como ela trata as pessoas pobres?

6. Muito melhor

7. Um pouco melhor

8. Do mesmo jeito

9. Um pouco pior

10. Muito pior

77. NR

88. NA

99. NS

D.20. Na sua opinião, em uma escala de um a dez, sendo zero uma situação intolerável e dez uma situação tolerável, você julga que:

1. (ـ) aguardar um mês por uma consulta

2. (_) ter uma consulta de $15 \mathrm{~min}$

3. (_ não ser recebido pelo coordenador de saúde da Subprefeitura

4. (_ não ser recebido pela diretora do posto de saúde

5. (_ não ter o remédio que o médico indicou no posto

6. (_) esperar um mês por uma cirurgia urgente

7. (_) ser mal tratado por uma enfermeira

8. (_ ) ser colocado na maca no corredor do hospital

9. (_ ) andar 20 min para chegar no posto de saúde

10. (_ ) precisar pegar ônibus para chegar no hospital

11. (_ não ter a especialidade de médico que você precisa no posto perto de sua casa

12. (_ não poder ser atendido no posto por não morar naquela região 


\section{V - Avaliação das percepções do Conselheiro sobre o sistema público de saúde}

\section{E.1. Situação 01}

"Há uns seis meses, Seu José não vem passando bem. Como ele trabalha de segunda a sábado até as 19 horas, resolve ir à noite diretamente ao pronto-socorro do Hospital Municipal, pois neste horário os postos de saúde já estão fechados. Depois de muita confusão (o guarda não queria deixá-lo entrar, pois alegava que o pronto socorro era para atender gente que estivesse muito mal, com sangramento, parindo ou desmaiando), conseguiu entrar e obter uma ficha para atendimento. Com a ficha na mão, ele teve que aguardar mais de uma hora. Finalmente, foi chamado pelo doutor de plantão, que disse que seu caso não era de urgência, Ihe deu uma aspirina e o encaminhou para a UBS.

No dia seguinte, Seu José foi, na madrugada,para o posto, que abriu às 8 horas com uma grande fila. Ele foi uma das 16 pessoas que conseguiram uma senha para serem atendidas. Após esperar mais de 2 horas, foi chamado pela auxiliar de enfermagem para entrar no consultório médico.

Ele relatou suas queixas ao médico, que lhe receitou umas vitaminas e um remédio para ele tomar quando tivesse dor de cabeça. O doutor não perguntou nada a Seu José.

Passados uns 15 dias sem qualquer melhora e cada vez mais fraco, com tremores e a dor de cabeça que já não passava com o remédio receitado, ele resolveu procurar a equipe de saúde de um outro posto onde ele ficara sabendo que era desenvolvido um trabalho na área de saúde do trabalhador. Lá diagnosticaram que seu José estava intoxicado com produtos químicos da plantação onde trabalhava.

Seu José foi enviado para tratamento em uma cidade grande. Depois do preenchimento da Guia de TFD (Tratamento Fora do Domicílio), Seu José partiu para a capital".

Em uma escala de um (01) a dez (10), sendo um "discordo totalmente", e 10 "concordo totalmente", você:

\begin{tabular}{|c|c|c|}
\hline & ) & $\begin{array}{l}\text { acha que a Prefeitura da cidadezinha } \\
\text { agiu corretamente }\end{array}$ \\
\hline 2.( & ) & $\begin{array}{l}\text { acha que a Prefeitura da cidadezinha } \\
\text { agiu de maneira errada, e deveria } \\
\text { costruir um hospital }\end{array}$ \\
\hline 3. ( & ) & $\begin{array}{l}\text { o hospital da cidade grande não } \\
\text { deveria receber pacientes de outras } \\
\text { cidades, o que as forçaria a construir } \\
\text { hospitais }\end{array}$ \\
\hline 4.( & ) & $\begin{array}{l}\text { os moradores da cidadezinha } \\
\text { deveriam se unir para reivindicar um } \\
\text { hospital }\end{array}$ \\
\hline
\end{tabular}




\begin{tabular}{|l|l|} 
5.( $\quad$ ) & $\begin{array}{l}\text { os moradores da capital deveriam se } \\
\text { unir para proibir a vinda de pacientes } \\
\text { de outras cidades }\end{array}$ \\
$6 .(\quad)$ & outras
\end{tabular}

\section{E.2. Situação 02}

O secretário de Saúde de Miracema do Oeste implantou o Programa de Saúde da Família (PSF) no seu município. Para isso, fez um projeto e, após aprovação no Conselho Municipal de Saúde, encaminhou-o à Comissão Intergestores Bipartite - ClB estadual que o remeteu ao Ministério da

Saúde para qualificação das equipes e assim receber o incentivo financeiro. Ele sabia que este é um programa prioritário do governo federal, definido como estratégia para implementação do SUS. Como a prefeitura decidiu não realizar concurso para contratar os(as) trabalhadores(as) para as equipes de saúde da família, o secretário buscou uma cooperativa para contratação do pessoal. Os médicos contratados para as equipes foram um ginecologista e um pediatra. No final

de seis meses, as familias cadastradas por essas equipes começaram a reclamar, pois não se oferecia atendimento para as pessoas que tinham pressão alta e diabetes. $O$ ginecologista dizia que somente iria atender mulheres e, assim mesmo, nos assuntos de sua competência. O pediatra, por sua vez, somente queria atender crianças.

Você acha que:

\begin{tabular}{|l|l|}
\hline 1.( $\quad$ ) & $\begin{array}{l}\text { a Prefeitura deveria chamar outra cooperativa } \\
\text { para contratar os medicos }\end{array}$ \\
\hline 2.( $\quad$ ) & $\begin{array}{l}\text { a Prefeitura deveria mandar a mesma } \\
\text { cooperativa contratar outros medicos }\end{array}$ \\
\hline 3.( $\quad$ ) & $\begin{array}{l}\text { a Prefeitura deveria mandar a mesma } \\
\text { cooperativa contratar mais medicos }\end{array}$ \\
\hline 4.( $\quad$ ) & $\begin{array}{l}\text { a Prefeitura deveria discutir com o Conselho } \\
\text { um perfil da população usuária do SUS, para, } \\
\text { depois contratar os médicos }\end{array}$ \\
\hline $5 .(\quad \quad)$ & $\begin{array}{l}\text { o Conselho deveria pedir o cancelamento deste } \\
\text { contrato com a cooperativa para rever o plano } \\
\text { de atendimento }\end{array}$ \\
\hline
\end{tabular}

E.3. Situação 03

No Município de Bom Retiro, a população está contente com os serviços de saúde.

Nos últimos quatro anos, o secretário de Saúde caprichou, pois a condição de gestão plena do sistema municipal, conquistada pelo município há dois anos, permitiu que todos os habitantes do lugar tivessem mais centros de saúde e mais leitos hospitalares. E tudo com melhor qualidade do que antes: tem remédio, tem exames, tem bom atendimento.

Recentemente, um grupo de aproximadamente 1.800 trabalhadores sem-terra acampou na região, dentro do município. São centenas de famílias acampadas precisando de assistência à saúde. No entanto, toda vez que esses trabalhadores sem-terra chegam às unidades de saúde, não são atendidos, e a explicação é a de que os serviços do SUS são destinados apenas aos moradores do município, que se os Sem Terra forem atendidos, o 
sistema de saúde será sobrecarregado e as pessoas que moram em Bom Retiro terão o atendimento piorado.

Tendo em vista as situações acima, você acha que:

\begin{tabular}{|l|l|}
\hline 1.( $\quad$ ) & $\begin{array}{l}\text { a atitude em relação aos Sem Terra está } \\
\text { correta, os moradores que pagam impostos } \\
\text { têm prioridade no atendimento }\end{array}$ \\
\hline 2.( $\quad$ ) & $\begin{array}{l}\text { a atitude não está correta, mas os Sem Terra } \\
\text { deveriam reivindicar verbas para o governo do } \\
\text { Estado para poderem ser atendidos no } \\
\text { município }\end{array}$ \\
\hline 3.( $\quad$ ) & $\begin{array}{l}\text { o município deveria atendê-los, } \\
\text { independentemente do que aconteça }\end{array}$ \\
\hline $4 .(\quad \quad)$ & $\begin{array}{l}\text { os Sem Terra deveriam ir ao Conselho } \\
\text { Municpal de Saúde para reivindicar } \\
\text { atendimento }\end{array}$ \\
\hline $5 .(\quad \quad)$ & $\begin{array}{l}\text { o Conselho Municipal, juntamente com os Sem } \\
\text { Terra e a prefeitura, deveriam solicitar mais } \\
\text { verbas para o governo do Estado, para que daí } \\
\text { os Sem Terra sejam atendidos }\end{array}$ \\
\hline $6 .(\quad \quad)$ & outra \\
\hline
\end{tabular}

\section{E.4. Situação 04}

Joaquim, Conselheiro do Conselho Gestor da subdivisão administrativa de Rui Barbosa, no município de Jacarezinho, é, também, delegado do Orçamento Participativo daquela comunidade.

Joaquim é muito querido entre todos da região, pois é um dos primeiros moradores do local, e auxiliou muito no processo de urbanização da região, ajudando a conseguir mutirões, postos de saúde e o hospital da região, e ajudou até a eleger um vereador, que representa os interesses da região no município, o José Bevilaqua.

Devido à sua participação ativa nas reuniões do $O P$, e de seu prestígio como conselheiro distrital de saúde, Joaquim conseguiu mostrar no Conselho Municipal do OP que sua região deveria ser contemplada com um posto de especialidades em geriatria.

Valdomiro, filho de seu Joaquim, está erguendo um "puxadinho" no terreno de Joaquim, pois se casou e quer mudar com a mulher para um teto seu.

Na construção do posto de geriatria, sobraram algumas telhas e tijolos, que seu Joaquim pediu ao Conselho para dar a seu filho, para ele terminar o puxadinho. O Conselho permitiu, porque o material não teria mais serventia, a obra já estava pronta.

Tendo ficado sabendo da história da comunidade de Rui Barbosa, no município de Jacarezinho, você acha que:

1.( $\quad$ ) $\begin{aligned} & \text { seu Joaquim fez bem ao pedir as sobras de material } \\ & \text { para o Conselho antes, porque ele é soberano }\end{aligned}$ 


\begin{tabular}{|c|c|c|}
\hline 2.( & ) & $\begin{array}{l}\text { ele poderia ter pego de qualquer maneira, afinal de } \\
\text { contas, o material sobrou mesmo }\end{array}$ \\
\hline 3. ( & ) & $\begin{array}{l}\text { o Conselho não deveria ter dado ao seu joaquim, e } \\
\text { sim a algum movimento de moradia que tenha } \\
\text { mutirão }\end{array}$ \\
\hline & ) & $\begin{array}{l}\text { o Conselho não tem autoridade pra dar o material } \\
\text { para ninguém. Deveria, antes, ter pedido que se } \\
\text { instaurasse um processo de averiguação para ver } \\
\text { porque sobrou material da obra }\end{array}$ \\
\hline $5 .($ & ) & outras \\
\hline
\end{tabular}

E.5 - Qual foi a primeira vez que você se engajou em atividades participativas, e por que? De lá para cá, em que tipo de associações você fez parte?

\section{I- Avaliação Socioeconômica}

F.1. Qual sua renda familiar?

$\mathrm{R} \$$

F.2. E sua renda individual?

$\mathrm{R} \$$

F.2. Quantas pessoas moram na sua casa?

F.3. Qual a data de seu nascimento

F.4. Estudou até que série na escola?

F.5. Cite as três últimas ocupações que teve: 


\begin{tabular}{|l|l|l|}
\hline ANO & LOCAL DE TRABALHO & ATIVIDADE DESENVOLVIDA \\
\hline & & \\
\hline & & \\
\hline & & \\
& & \\
\hline
\end{tabular}

Nome do entrevistado:

Data da entrevista:

Conselho:

Início:

Fim:

OBRIGADO 